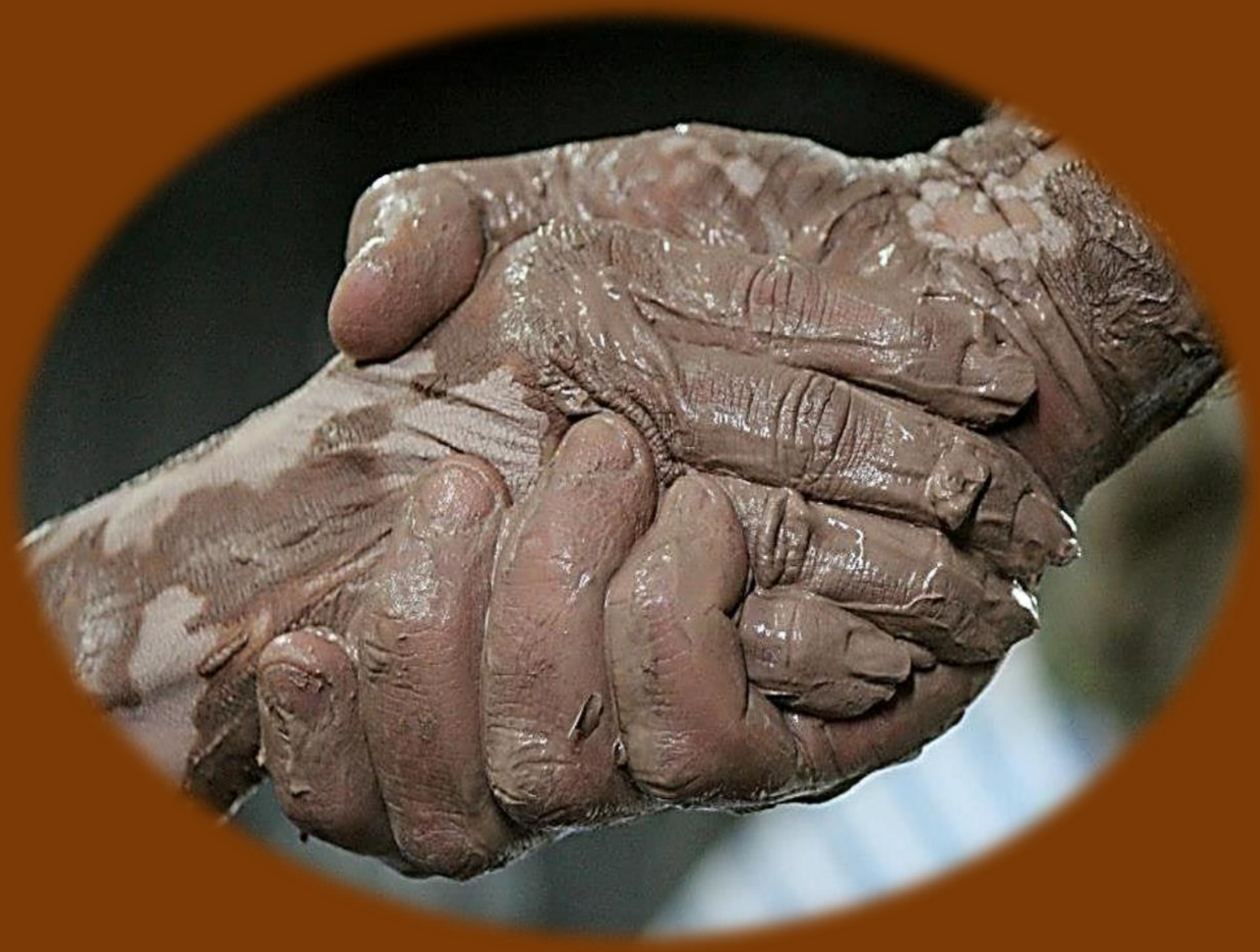

Maragogipinho - as vozes do barro:

práxis educativa em culturas populares 
Imagem da capa: http://www.franciscolorusso.com/blog/ 
Sonia Carbonell Alvares

\title{
Maragogipinho - as vozes do barro: práxis educativa em culturas populares
}

\author{
Tese de doutorado apresentada como requisito parcial para a obtenção \\ do título de Doutora em Educação no Programa de Pós-Graduação \\ em Educação da Faculdade de Educação da Universidade de \\ São Paulo, na área temática de Cultura, Organização \\ e Educação, sob a Orientação do Prof. Dr. \\ Marcos Ferreira-Santos.
}

São Paulo 
4

Serviço de Biblioteca e Documentação

Faculdade de Educação da Universidade de São Paulo

375.7 Alvares, Sonia Carbonell

A473m Maragogipinho - as vozes do barro: práxis educativa em culturas populares / Sonia Carbonell Alvares; orientação Marcos Ferreira-Santos. São Paulo: s. n., 2015. $375 \mathrm{p}$.

Tese (Doutorado - Programa de Pós-Graduação em Educação. Área de Concentração: Cultura, Organização e Educação) - - Faculdade de Educação da Universidade de São Paulo.

1. Cerâmica 2. Maestria 3. Artesanato (Educação) 4. Arte-educação 5. Cultura popular I. Ferreira-Santos, Marcos, orient. 
Sonia Carbonell Alvares

Maragogipinho - as vozes do barro: práxis educativa em culturas populares

Tese apresentada à Faculdade de Educação da Universidade de São Paulo como requisito parcial para a obtenção do título de Doutora em Educação.

Linha de Pesquisa: Cultura, Organização e Educação.

Aprovada em:

Banca examinadora:

Orientador: Prof. Dr. Marcos Ferreira-Santos

Instituição: FE-USP

Prof. Dr.

Instituição:

Assinatura

Prof. Dr.

Instituição:

Assinatura
Assinatura:

Prof. Dr.

Instituição:

Assinatura

Prof. Dr.

Instituição:

Assinatura 

Para Adelaide, minha mãe.

Para Ana,

Pablo, Júlio, meus filhos.

No sentido da espiral da vida. 
8 


\section{agradecimentos}

a todos os artesãos e artesãs de Maragogipinho que, generosamente, me receberam em suas olarias e casas, presentearam meus olhos com seus belos trabalhos e meus ouvidos com suas vozes gentis e o seu doce sotaque.

ao mestre Marcos Ferreira-Santos, pela poesia de seus ensinamentos, pela escuta sempre atenta, pela liberdade, delicadeza e amizade com que me orientou nesta pesquisa.

ao meu companheiro Pato Papaterra, pelo apoio incondicional, pelas agudas reflexões, pelas leituras do texto, pela parceria, por sua alegria que me contagia.

ao amigo Cláudio Bazzoni pelo carinho, pelo incentivo constante, pela revisão sensível e cuidadosa do texto.

ao amigo Waldemar Zaidler, pela generosidade, por suas sábias contribuições e pelo prazer das prosas de domingo.

à Beth Lima, por me receber carinhosamente em seu atelier e pelas sugestões iniciais que alavancaram esta pesquisa. 
ao querido Rubens Matuck, por também me receber carinhosamente em seu ateliê, pela deliciosa tarde de ensinamentos, pelo empréstimo de seus preciosos livros.

às professoras Lalada Daglish e Katsuko Nakano pelas inestimáveis sugestões no exame de Qualificação.

ao oleiro Dênis Souza, pelos vídeos, pelas contribuições, pela disponibilidade e paciência com que esclareceu as minhas dúvidas.

À Nádia Teixeira Moreira, pela tarde de prosa e pelo acesso ao seu material de pesquisa.

À querida Maria Luiza Togni, pelo apoio, carinho e sorriso de todas as manhãs.

À irmã-amiga Cris Cruz, sempre tão perto.

À FAPESP, pela bolsa de estudos que possibilitou e viabilizou economicamente esta pesquisa. 


\section{resumo}

Este trabalho apresenta uma observação acurada do universo da cerâmica no povoado de Maragogipinho, Bahia. A pesquisa revela quem são os mestres e mestras do barro, dá a conhecer o seu processo criativo e educativo. Esses homens e mulheres são protagonistas do patrimônio cultural imaterial brasileiro, eles detêm e socializam conhecimentos que perpassam gerações, saberes tecidos em práticas de ensino não sistematizadas e nem legitimadas pelas culturas hegemônicas. A educação artesanal está fundada na ancestralidade, na repetição e na invenção, no constante diálogo entre a tradição e a emergência da modernidade: novas formas de criação e antigos segredos de ofício se misturam, numa tensão permanente entre transformação e conservação. $O$ artesão e a artesã vivem o seu legado cultural e o mantêm vivo, reinventando-o e atualizandoo eternamente. Essa herança conserva a conexão com o passado, mas se reveste de novos símbolos e significados no presente para fortalecer a identidade dos autores e de suas comunidades, e para dar sentido ao futuro.

Palavras-chave: Cerâmica - Maestria - Educação artesanal - Arte-educação Culturas populares 


\section{abstract}

This work presents an accurate observation of the pottery universe in the village of Maragogipinho, Bahia. The research reveals who are the masters of clay, makes known their creative and educational process. These men and women are protagonists of the brazilian intangible cultural heritage, they preserve and socialize knowledge across generations, originated in unsystematic practices, not legitimized by the hegemonic cultures. Craft Education is established on ancestry, on repetition and invention, in constant dialogue between tradition and the emergence of the modernity: new ways of creating and old trade secrets are mixed on a permanent tension between transformation and conservation. The craftsman lives his cultural legacy and keeps it alive reinventing and updating it forever. This heritage preserves the connection with the past, but acquires new symbols and meanings to strengthen the identity of the authors and their communities, and to make sense of the future.

Keywords : Ceramics - Mastery - Craft Education - Art Education- Popular cultures 


\section{sumário}

entoação

objetivos

percurso metodológico

organização do texto

I. VOZ DA AUTORA

II. RUMORES DE MARAGOGIPINHO

2.1. O povoado

2.2. As olarias

2.3. A AAMOM: Associação de Auxílio Mútuo dos Oleiros de Maragogipinho

2.4. Raízes de Maragogipinho

III. CLAMORES DO TEMPO: HISTÓRIA DOS OFÍCIOS ARTESANAIS

3.1. O período medieval

3.2. Artesanato e arte na Renascença

3.3. Os ofícios no Brasil colonial e imperial 
3.5. A produção artesanal no Brasil moderno

IV. A VOZ SILENCIOSA DOS OBJETOS

4.1. Caxixis

4.2. Beleza e utilidade

4.3. Anonimato

V. CADÊNCIAS: CORPO E CORPOREIDADE NO FAZER ARTESANAL

5.1. O corpo-sujeito de Merleau-Ponty

5.2. A sabedoria das mãos

5.3. Relações fraternas mediadas pelo fazer artesanal

5.4. A cadeia produtiva da cerâmica de Maragogipinho

5.4.1. Divisão do trabalho entre homens e mulheres

5.4.2. Extração do barro

5.4.3. Processamento do barro 


\section{índice de fotografias}

Minha primeira queima na técnica Raku, 2008

Peças incandescentes na queima Raku 50

Vaso torneado em argila, Sonia Carbonell, 2013 51

Meu ateliê-escritório, 2012 57

Teto de um forno de capela 60

Placa na entrada do povoado 61

Vista de um trecho do Recôncavo Baiano 66

Trevo de entrada para Maragogipinho 67

Trevo de entrada para Maragogipinho 68

Igreja Matriz Nossa Senhora da Conceição 69

Rua de Maragogipinho 70

Rua de Maragogipinho 71

As boas vindas pelo menino transportando peças para a casa da pintora 72

Rua de Maragogipinho 73

Bar 74

Fundos de uma casa 74

Fachada de uma casa 75

Chegada do barro 
Peças prontas esperando pelo caminhão de transporte

Praça principal com olarias

Praça principal

Cais

Vista externa de uma olaria

Caminho entre as olarias (antes do calçamento)

Caminho entre as olarias (depois do calçamento)

Forno caieira

Forno de capela

Oleiro: Seu Zé

Amassador: Marinaldo Manuel de Jesus 1

Brunideiras: Joseane Evangelista e Jussara Evangelista

Marijose, presidente da AAMOM

Janete dos Santos brunindo um porquinho de barro

A igreja Matriz vista do cais 100

Tabatinga em pó 104

Porcos de barro à espera de transporte 104

Baiana e boi-bilha 105

Maragogipinho em meados de 1970 108

Josep Albers (1888-1976), professor da Bauhaus 126

Mário de Andrade em viagem à Amazônia 130

Mestre Vitalino - "Emboscada" 133

Potes no interior de uma olaria 140

Boneca de barro na janela da olaria de Seu Zé 
Moringas

Porrão e talha

Bujão

Quartinheiro

Baiana

Mestre Vitorino com seu boi-bilha

Boi-bilha feito por Seu Zé na varanda de sua casa

Porco-cofre

Mulheres pintando porcos-cofres com tinta acrílica

Caxixis na Feira de Caxixis

Sebinho, artesão de Maragogipinho na Feira de Caxixis

Detalhe de uma peça de Seu Zé

Artesão cortando uma placa de argila

Mãos sonhadoras de Dona Santa, pintora de 87 anos

Menino brincando com o barro numa olaria

Sr. Natal extraindo barro

Transporte em animais de carga, que levam, em média $300 \mathrm{Kg}$ de barro

Barro para uso coletivo dos oleiros

Depósito de barro dentro de uma olaria

Pisa do barro

Pé do oleiro Nené

Amassador Irapuã amassando o barro no empelador

Mão do amassador em busca do barro justo 
Táfica do oleiro Padre

Ferramentas do oleiro Tutuna

Ferramentas fabricadas para cerâmica

Mãos torneando

Talhas secando no interior da olaria

Vasos secando ao sol

Brunimento de uma talhinha pintada com tauá

Zelita pintando uma moringa com tabatinga

Pincel de talisca de palha de coqueiro com pelo de gato

Sopeiras pintadas com tauá e tabatinga

Queima em forno caieira

Arrumação do forno caieira

Queima no forno caieira

Queimador Jorge dos Santos alimentando forno caieira

Oleiro Dilton Duarte desenfornando forno de capela

Pratos vitrificados

Peças no cais esperando pelo transporte

Mestre Seu Zé modelando uma baiana

Nené com sua moringa sem fundo

Parede externa da casa de Mestre Vitorino

Mestre Vitorino

Boi-bilha de Mestre Vitorino 
Prato confeccionado por Mestre Nelinho

Mestre Seu Zé em sua olaria

Baianas na olaria de Mestre Seu Zé

Mestra Dona Santa

Pincel de pelo de gato, confeccionado por Dona Santa

Pintura com tabatinga em papel, Dona Santa, 2010

Pintura com tabatinga em papel, Nailse Mota e Neusa Mota, 2010

Isaac, Dona Santa e Neusa

Escultura de São Francisco em processo de construção na frente da casa de Mestre Rozalvo

Mestre Rozalvo em sua casa

Escultura em barro de Rozalvo Santana

obras-de-artistas-de-raro-talento

Mestre Nené

Desenho de Mestre Nené

Porrões recém-desenfornados na olaria de Mestre Nené

Mestre Padre

Boneca na olaria de Mestre Padre

Boi de Mestre Padre

Mestra Zelita pintando

Efeitos de pingos acumulados na pintura com tabatinga

Arleide modelando durante a conversa com Mestra Zelita

Pintura com tabatinga em papel, Arleide B. Santos, 2010

Modelagem de Arleide Brito dos Santos 
Mestre Tutuna

Mestra Nailse

346

Mestre Almerentino

Mestra Mil

Mestra Neuza

Mestre Miro

350

Mestra Rosalina

351

Mestres: Almerentino, Almerentino Filho, Seu Zé, Antônio Luiz e Padre

352

Paredes com fragmentos de cerâmica no sítio arqueológico Hatahara, no Amazonas

354

Prato em argila, Sonia Carbonell, 2014

375 



\section{entoação}

$O$ artista que corta a madeira, martela o metal, molda a argila, talha o bloco de pedra, traz até nós

um passado do homem, um homem antigo, sem o qual não estaríamos aqui. Não é admirável vê-lo em pé, entre nós, em plena era mecânica, esse sobrevivente obstinado da era das mãos?

Os séculos passaram por ele sem alterar sua vida profunda, sem fazê-lo renunciar a seus modos antigos de descobrir o mundo e de inventá-lo.

Henri Focillon

Cultivo predileção estética e admiração pelas manifestações artísticas do povo latino-americano, que reúnem costumes, crenças religiosas, festas, tradições, fazeres individuais e comunitários de riqueza e beleza incomensuráveis. Se observarmos bem, veremos que, em todo canto da América Latina, há sempre alguém que se dedica a um fazer das mãos: entalhando um pedaço de madeira, raspando uma pedra, modelando barro, costurando, bordando, trançando fios, palhas e fibras de todos os tipos. Na cidade, no sertão, na floresta, na praia ou na 
montanha, pessoas produzem objetos artísticos que reelaboram fragmentos dispersos de suas raízes e de sua história.

O universo das artes populares nos revela faces sombreadas que não se mostram facilmente, nem são veiculadas pelas mídias contemporâneas: a memória de cotidianos passados e presentes. Os fazeres artesanais remetem ao dia-a-dia de homens e mulheres que vivem na periferia da lógica e da racionalidade letradas, mas que com seus trabalhos artísticos preservam e transmitem valores de culturas ancestrais.

Fortemente enraizada nas culturas e no modo de viver das pequenas comunidades, ou das periferias urbanas - onde adquire características próprias e se manifesta como canal expressivo do habitante da grande cidade -, a arte popular exprime o ponto de vista de pessoas que geralmente passam despercebidas, sem o conhecimento e o reconhecimento do público. Na América Latina, esses artistas são chamados de artesãos ${ }^{1}$, eles quase não participam do mercado de bens simbólicos, sua produção é comumente excluída dos museus e timidamente incluída nos programas político-culturais de preservação do patrimônio. No entanto, suas obras que geralmente apresentam temas da vida

\footnotetext{
${ }^{1}$ Em alguns pontos do texto utilizo a palavra artesão para compreender também a mulher artesã.
} 
social e do imaginário das culturas dos povos, em linguagens e poéticas peculiares, têm forte poder de comunicação, capaz de ultrapassar fronteiras sociais, econômicas e culturais, interessando e encantando a vários públicos.

Artesãos e artesãs vêm enfrentando economias em crise, globalização e instabilidades sociais. Algumas vezes valorizadas, outras menosprezadas, as suas produções artísticas transitam por um espaço indefinido entre o consumo das classes menos favorecidas, as modas midiáticas e as predileções da elite. Eles são gente simples que, sem tomar parte ativa nas políticas econômicas, são sorvidos para um redemoinho econômico que os afasta de suas próprias raízes e os aparta do sentido sociocultural de seu trabalho. Muitos, por conta da sobrevivência, acabam por abandonar práticas ancestrais, deixando de criar para produzir objetos vazios, sem identidade, como tão bem explicita o artesão goiano Zé do Carmo: "Hoje existe essa mania de igualar tudo. Antes as pessoas diziam: 'veja o que você tem de melhor e traga'. Agora, você deixa de ser autor para ser uma máquina" (Lima, 2008, p. 173).

Práticas artesanais vêm se esvaindo na sociedade globalizada contemporânea, técnicas construtivas milenares, saberes que não são veiculados por nenhuma escola. Perdem-se também modos significativos de partilha desses conhecimentos 
tradicionais, formas originais de ensino e aprendizagem não separadas da vida vivida. A partilha é um valor primordial nas culturas populares. Ao contrário da palavra transmissão, que limita um caminho unívoco do mestre ao discípulo, a partilha pressupõe troca, na dimensão do bem comum. A constituição da vida nessas comunidades é tecida nas práticas do fazer. $O$ trabalho artesanal traduz relações sociais de gênero, relações familiares, comportamentais e espaciais engendradas em valores solidários, a partir da importância da associação e da cooperação na família, na vizinhança ou na comunidade como um todo, onde a vida é o propósito comum do grupo.

As artes populares articulam saberes informais que se mantêm ao longo do tempo pela tradição oral e se recriam no contato com as tecnologias e os modos de vida contemporâneos, circunscrevem conteúdos culturais e expressam maneiras de ser de quem as elabora, obras que revelam a grandeza humana contida em cada uma dessas pessoas.

Tião Rocha, antropólogo e educador popular, afirma que fazer bordados, cestos e potes é atividade universal, mas não são universais as maneiras do fazer, nem o material com que se faz e nem as formas ou os padrões utilizados para fazê-los. As particularidades do fazer e do ensinar a fazer, as ferramentas, as propriedades 
constitutivas dos materiais utilizados, as distinções de estilo são aspectos que conferem marcas de identidade às peças e aos autores (Rocha, 2010, p. 1).

Só no Brasil, existem milhares de mestres artesãos. Mulheres e homens que, ainda pequenos, aprenderam um ofício com a mãe, pai, tio, avô. As peças que produzem são reconhecidas, no lugar e fora dele, como muito bem feitas. A maioria desses artesãos e artesãs apresenta habilidade e disponibilidade para ensinar, multiplicam conhecimentos de seus antepassados e suscitam discípulos em suas comunidades. Pelo país afora, as histórias desses mestres soam muito semelhantes. Mas não se pode deixar que apenas a semelhança permaneça em relevo. Porque é justamente a diferença entre suas trajetórias o que os resgata do anonimato, o que confere valor e identidade às culturas narradas por eles. Penetrar no universo singular dos artesãos é conhecer tradições vigentes e histórias perdidas, é ver representado em uma mesma obra a experiência pessoal do autor, bem como a vida da sociedade em que está inserido. O patrimônio e a identidade de cada povo, expressos por meio de sua produção artística, exibem tanto as marcas que o distinguem quanto as que o identificam. 
Como se sustentam no tempo e no espaço, como passam de geração a geração os saberes tecidos a partir de práticas artísticas e educativas não legitimadas pelas culturas dominantes?

\section{objetivos}

Esta tese se propõe a refletir sobre arte na dimensão do cotidiano, nas práticas sociais de pessoas com pouco ou nenhum letramento escolar. Ela afirma que as culturas populares configuram potentes referenciais de identidade dos povos e que a valorização do fazer artesanal constitui um meio para estimular o desenvolvimento sustentável de grupos humanos com alta vulnerabilidade social.

O estudo se dedica a revelar, compreender e socializar práticas artísticas e modos de partilha de conhecimentos tradicionais, na área da cerâmica, de artesãos brasileiros que vivem no anonimato, mas que exercem um importante papel sociocultural e econômico nas suas comunidades. Especificamente, este trabalho pretende ressoar no sentido de ajudar a incrementar a preservação e a salvaguarda de Maragogipinho como patrimônio cultural imaterial do Brasil. 
Para tanto, discute permanências e transformações, costumes e formas de expressão das sociedades artesãs no século XXI. A presença maciça da cultura planetária (global) e das novas mídias vem causando um temor, uma ameaça de desaparecimento dos signos culturais de identidade desses povos. A industrialização, a introdução de novos materiais e técnicas, tem causado efeitos ainda não totalmente mensurados no seio das comunidades. Entretanto, o que continua patente é a franca intensificação da desigualdade social: os artesãos permanecem empobrecidos, trabalham incansavelmente para obter uma renda irrisória, que mal dá para o sustento de sua família. Para essas pessoas que dependem de formas manuais de fabricação, a sobrevivência repousa em horizonte nebuloso, incerto, sua produção artística ainda penetra timidamente em nichos do mercado global, ao lado dos produtos industriais.

Reafirmamos aqui que a peça artesanal carrega consigo múltiplos significados ligados à vida humana e suas relações com a natureza, a valores éticos e estéticos, à visão de mundo e expressão cultural da comunidade em que é produzida.

Ante todo queremos sentar que la cultura es un apretado tejido de relaciones y que las artesanías abren una ventana para comprender y visualizar la conexión integral entre los elementos naturales, sociales y simbólicos del grupo social en cuestión (Turok, 1988, p. 19). 


\section{percurso metodológico}

A pesquisa empírica foi realizada em Maragogipinho, distrito da cidade de Aratuípe na Bahia, com homens e mulheres que se dedicam cotidianamente à produção de objetos de argila, oleiros e pintoras que habitam um lugar em que mais de noventa por cento da população se dedica ao trabalho com o barro.

Fui ao povoado duas vezes: em março de 2014 e em janeiro de 2015. Nas duas ocasiões, intentei uma imersão, a mais profunda possível. Encontrei os maragogipinianos extremamente receptivos, afáveis, disponíveis. Muitas das minhas conversas não foram gravadas intencionalmente, para não romper o fio da confiança instalada na informalidade e na fluência da prosa. Mantive um diário de campo em que registrei sensações, impressões, descobertas. Convivi com os artesãos e artesãs por dez dias, no total, o que considero um tempo exíguo. Nas duas voltas para casa, pude sentir a dimensão do manancial que há lá por descortinar, permaneceu em mim o desejo de retornar à Maragogipinho.

Nessa jornada, constatei que o ofício do artesão tradicional se enraíza em matrizes ancestrais que, ao longo dos séculos, modela homens e mulheres, encarna-se na totalidade desses seres. A dimensão da ancestralidade dá substrato a este 
trabalho. Ancestralidade, segundo Ferreira-Santos, compreende o traço constitutivo de nosso processo identitário, uma herança que vai além da existência pessoal, pois concerne ao grupo comunitário a que pertencemos: "Através da nossa voz, as vozes ancestrais reencontram o seu canto no mundo." (Ferreira-Santos, 2012, p. 60).

A opção pela narrativa e redação do texto em primeira pessoa assenta-se na ancestralidade enquanto processo constitutivo de minha identidade, que me ultrapassa e me impulsiona à recriação do mundo, nele (no texto) dialogam aspectos da minha herança biológica e cultural, da minha subjetividade e as intimações do mundo.

Esta outra faceta da noção de ancestralidade nos evidencia a noção de 'endividamento', como diz Paul Ricoeur, na medida em que somos o futuro que este passado tinha e nos cumpre atualizar suas energias mobilizadoras e fundadoras. Em resumo: nossa dívida com a ancestralidade é que temos que ser nós mesmos. Somente na realização de si mesmo é que a dívida com a ancestralidade se quita (Idem, p. 61).

Os procedimentos metodológicos da pesquisa se baseiam na fenomenologia. A palavra fenomenologia reúne dois radicais gregos: phaíno, que significa brilhar, 
fazer-se visível, mostrar-se, aparecer e lógos, que significa discurso, o que é dito, argumento, pensamento. Fenomenologia é o discurso daquilo que se mostra por si mesmo, que trata diretamente do fenômeno, interrogando-o, descrevendo-o e procurando captar sua essência. Husserl (2000) propõe a "volta às coisas mesmas", tal como elas se mostram aos nossos olhos e à nossa consciência. A investigação fenomenológica não se consuma na conceituação dos fenômenos, mas no lidar dos homens com eles, na trama de significados que as pessoas vão tecendo entre si ao se relacionarem com o mundo. Por meio da fenomenologia, o sensível recupera o estatuto de dimensão instituidora da experiência humana.

Portanto, procurei realizar este trabalho dentro do território da fenomenologia, no solo da ambiguidade constitutiva da experiência perceptiva, em um domínio em que o sensível não está divorciado do inteligível, nem a matéria se separa da forma. A postura fenomenológica me instigou, amiúde, a uma compreensão cada vez mais acurada do universo dos artesãos do barro. Na medida do possível, procurei enxergar os fenômenos tal como eles se apresentaram, fiz do cotidiano a porta de entrada para conseguir alcançar uma essência que se atualiza na minha existência. 
Nesse sentido, construí uma jornada interpretativa (Ferreira-Santos, 2012) que situa a compreensão de mim mesma como fundamental para lograr instalar-me na paisagem cultural que investigo. Assim, a minha própria constituição e o meu trabalho com o barro atuaram como pontos de partida, pontos de encontro e confronto, pontos de chegada nesta pesquisa. Nas palavras do meu mestre, Marcos Ferreira Santos: "uma boa pesquisa contém o olhar do geógrafo, o espírito do viajante e a escrita do romancista".

A mescla de geógrafo, viajante e romancista faz do hermeneuta alguém que parte, constantemente, para reencontrar-se. Esse é o panorama matutino de uma 'gnose', isto é, o conhecimento do meu mundo interior no interior do mundo (Ferreira-Santos, 2011, p. 245).

\section{organização do texto}

O texto que segue está organizado em seis capítulos. No capítulo primeiro, apresento-me, sintonizo minha voz em uma breve biografia e apresento alguns dos caminhos que trilhei até chegar a esta pesquisa. Destaco, especialmente, como teci este trabalho entrelaçando os fios da minha experiência profissional na 
Arte e Educação de Jovens e Adultos, do meu aprendizado na cerâmica e da leitura do livro "A caverna", de José Saramago.

No capítulo segundo, escutamos os primeiros rumores de Maragogipinho. A série de imagens e o texto descritivo traduzem meu olhar fenomenológico sobre o povoado, almejando uma imersão do leitor nesse lugar extraordinário, território genuíno do barro: nos ambientes singelos e rudimentares das olarias, na riqueza humana de seus habitantes, nas raízes de sua história. Em Maragogipinho, podemos descansar nossos olhos urbanos no esparramo da paisagem, no tempo remansado das pessoas, no cheiro de barro que impregna todos os cantos.

No capítulo terceiro, ouvimos as histórias da História. A compreensão de como a humanidade constituiu-se por meio do artesanato e de como permanece constituindo-se abre uma janela para enxergar a complexidade e o refinamento do objeto artesanal e para refutar a ideia de artesanato enquanto atividade primitiva. Como expressão da cultura, o artesanato é dinâmico e se transforma permanentemente. Mesmo que conserve formas antigas de elaboração, seus usos e significados se atualizam de acordo com as necessidades e características dos povos que o produz. 
Ouvir a voz silenciosa do objeto artesanal é o tema do capítulo quarto. O objeto artesanal é anônimo e constitui-se na interface entre a funcionalidade e a beleza. Juntamente com as pessoas e os animais, os objetos de barro coabitam Maragogipinho. Na verdade, os objetos são em maioria: dentro das olarias, esperando a secagem ou a queima; na frente e nos fundos das casas, esperando a brunição ou a pintura; nas encruzilhadas e no meio das ruas, esperando transporte; na beira do rio, eles estão por todas as partes. Mudos, esses corpos cerâmicos dialogam conosco e fazem ecoar sua vida.

O capítulo quinto leva-nos a escutar as vozes do corpo do artesão ceramista, o compasso, o ritmo, a harmonia com que constrói e orquestra saberes. Na ponta de cada um dos dedos da mão, há um cérebro, no dizer de Saramago. Os cérebros das mãos são os que primeiro percebem e compreendem o mundo, são eles que regem o cérebro da cabeça, segundo o romancista. A cadeia produtiva do trabalho com cerâmica é toda corporal e os conhecimentos advindos dela constituem o patrimônio cultural imaterial de Maragogipinho. A corporeidade no fazer artesanal deflagra, entre outras coisas, a solidariedade entre os artesãos.

No último capítulo, ouvimos as vozes dos mestres do barro. Em comunidades tradicionais, a maestria não requer diplomas nem certificados. Sua legitimação se 
faz no dia-a-dia, no seio da história oral. O mestre detém, socializa e recria saberes que trespassam gerações; unifica em seu fazer artesanal a identidade social do seu povo. O mestre ou a mestra não ensina somente a tornear ou a pintar um objeto. Para além disso, os mestres ensinam como relacionar-se com a peça artesanal, por meio da posse de um repertório cuja partilha de saber incita o aprendiz à uma tomada de consciência de seu modo de ser e estar no mundo.

Os acordes finais da tese ressoam para alertar sobre a importância de salvaguardar Maragogipinho, devido à sua incomensurável riqueza imaterial de saberes e fazeres individuais e coletivos; para tornar Maragogipinho Patrimônio Cultural Imaterial do Brasil. Território de mestres, de guardiões da cerâmica, Maragogipinho congrega culturas e conhecimentos tradicionais que necessitam urgentemente ser preservados e partilhados. 
Começar pelo princípio, como se esse princípio fosse a ponta sempre visível de um fio mal enrolado que bastasse puxar e ir puxando até chegarmos à outra ponta, a do fim,

e como se, entre a primeira e a segunda, tivéssemos tido nas mãos uma linha lisa e contínua em que não havia sido preciso desfazer nós nem desenredar estrangulamentos, coisa impossivel de acontecer na vida dos novelos e, se uma outra frase de efeito é permitida, nos novelos da vida. (...) Puro engano de inocentes e desprevenidos, o princípio nunca foi a ponta nítida e precisa de uma linha, o princípio é um processo lentíssimo, demorado, que exige tempo e paciência para se perceber em que direção quer ir, que tenteia o caminho como um cego, o princípio é só o princípio, o que fez vale tanto como nada. Saramago, 2000, p. 71. 


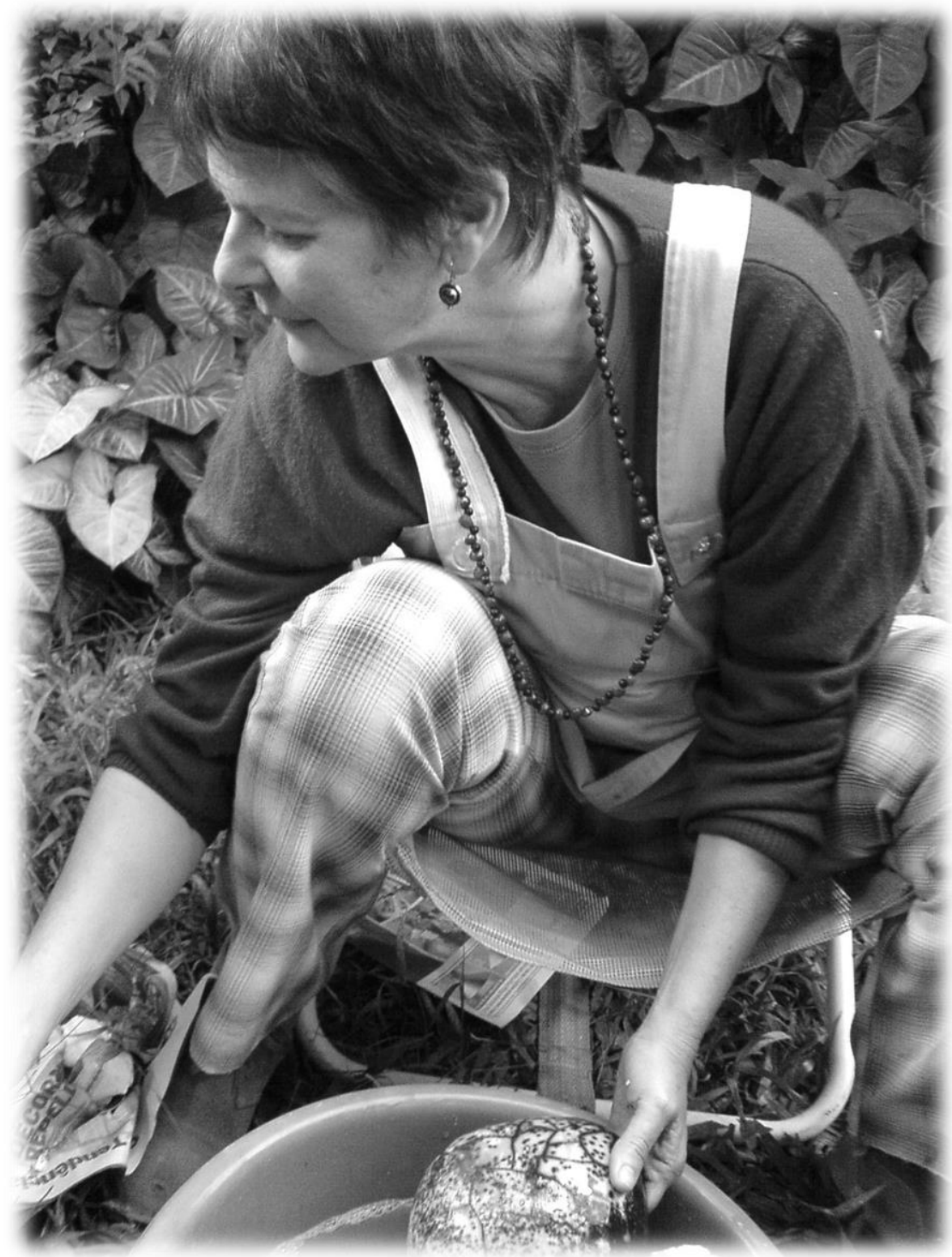

Minha primeira queima na técnica Raku, 2008 


\section{VOZ DA AUTORA}

Para ser grande, sê inteiro: Nada teu exagera ou exclui. Sê todo em cada coisa.

Põe quanto és no mínimo que fazes. Assim em cada lago a lua toda brilha, porque alta vive.

Ricardo Reis

Este trabalho é polifônico, nele se podem escutar timbres de vozes de mestres artesãos, pensadores, poetas, a minha voz. Quando efetivamente sentei e comecei a produzi-lo, estava com cinquenta e quatro anos de idade. No entanto, ele me habita desde que me conheço por gente. Sua urdidura começou a ser tecida há vários anos, não sei bem quando, talvez na infância, quando a minha mãe voltou a estudar. Ela se matriculou no Curso Normal no grupo escolar onde eu e a minha irmã fazíamos o Jardim de Infância, em Porto Alegre. Cedo, pela manhã, íamos as três para a escola. À tarde, quando voltávamos a nos reunir, em casa, lembro que minha mãe se enfiava nos livros e preparava trabalhos que eu adorava observar. Eram atividades para ser aplicadas na pré-escola: desenhos mimeografados, 
calendários, recortes e colagens de animais, flores, imagens de revistas, de papéis de presente, figurinhas de passar ${ }^{2}$, jogos coloridos construídos artesanalmente por ela, tudo sempre realizado com muito capricho e, principalmente, com prazer. Acho que esse deleite que ela sentia preparando suas "coisas de escola" foi a semente para deflagrar todo o sentido estético que, bem mais tarde, busquei e encontrei no trabalho com a arte e a educação.

Minha trajetória neste mundo é matizada por vários caminhos. Já fui bailarina, atriz, sorveteira, auxiliar de escritório, artesã, pesquisadora, ceramista e educadora. A iniciação acadêmica e profissional se deu pelo teatro e, até hoje, apesar de ter me distanciado de sua prática, continuo a acreditar que a natureza coletiva do teatro faz dele a linguagem artística mais solidária, a que mais contribui para reverter o individualismo presente na escola e na sociedade. Acordo mútuo é um binômio que reverbera em mim desde os anos 80 , quando cursava a universidade e dava aulas de teatro. Acordo mútuo constitui uma expressão bastante usada no livro "Improvisação para o Teatro", de Viola Spolin, refere-se à força do grupo que atua, que entra em acordo e compartilha, liberando um conhecimento construído coletivamente. Para mim, é sinônimo de alimentar-se no

2 Figurinhas de passar ou decalques eram imagens autocolantes que, mergulhadas em água, soltavam a cola e depois precisavam ser alisadas ou passadas a ferro para aderir à superfície em que se pretendia fixá-las. 
olho do outro, de respeito à diferença, de tolerância, de convivência solidária, de construção grupal, valores que sempre preservei e defendi com unhas e dentes.

Sou arte-educadora há quase trinta anos. Já dei aulas para crianças, adolescentes, professores, coordenadores. Mas o público com quem mais gosto de compartilhar uma sala de aula é o da EJA, a Educação de Jovens e Adultos. Durante muito tempo, atuei como professora de Artes Visuais e Teatro para adultos no curso supletivo do Colégio Santa Cruz, em São Paulo.

Meus encontros com os alunos, noite após noite, ano após ano, sempre tiveram a marca do prazer, do afeto, da dignidade. As salas de artes em que dei aulas no "Santa" constituíram verdadeiros territórios de criação e de cultivo da beleza, em um sentido profundo. Coroei essa bela experiência com uma dissertação de mestrado, em 2006.

A produção do mestrado foi saborosa. Consistiu em uma maneira de compartilhar com meus alunos a dimensão ética e estética que se instala numa sala de aula da EJA. Sentia-me dominada por uma vontade de honrar e enobrecer aquelas pessoas preteridas, tão sofridas, tão trabalhadoras, que despendiam um esforço extraordinário no estudo. Via que ao escolherem e trilharem o caminho da escola, 
eles explicitavam singelamente seu sentimento de inconclusão. $\mathrm{O}$ amor que sentia - e ainda sinto - por esse coletivo humano, assim como a experiência acumulada fizeram transbordar uma pesquisa acadêmica.

A dissertação de mestrado, realizada na FEUSP, obteve o Prêmio Internacional CREFAL (Centro de Cooperación Regional para la Educación de Adultos en América Latina y El Caribe) de melhor tese de Educação de Jovens e Adultos, em 2007, no México, onde foi publicada em espanhol. Também resultou no livro: "Educação Estética na EJA: a beleza de ensinar e aprender com jovens e adultos", publicado pela Editora Cortez, em 2012. Essa pesquisa começou refletindo sobre a arte na escola e terminou apresentando a estética à educação, como um meio para restabelecer o prazer de aprender e de ensinar dentro da instituição escolar, iluminando a beleza que há em toda a relação de ensino e aprendizagem.

Na educação, experimentei e consolidei diferentes práticas de ensino e aprendizagem da arte. Basicamente, com o tempo, aprendi com os alunos a me libertar de valores educativos cartesianos, nos quais fui educada. O conhecimento é dotado de tanto rigor científico que a sua produção, no espaço escolar, fica totalmente subordinada aos imperativos da racionalidade, da competência e da mestria técnica. O corpo do aluno, território da aprendizagem, é praticamente 
ignorado, bem como a dimensão do sensível e a da experiência vivida. Na escola, as coisas são aprendidas como sendo passíveis de determinação científica, redutíveis a um conjunto de propriedades unívocas, que a ciência pode reconstruir.

A prática da arte e o filósofo Merleau-Ponty me revelaram que o sensível não é subjetivo e obscuro como se quer fazer crer, o sensível não se localiza na esfera da sensação, o sensível concerne ao sujeito e ao mundo, habita também as coisas, a carne do mundo ${ }^{3}$. O sensível cumpre uma função de conhecimento e a fenomenologia the restitui este estatuto. A palavra conhecimento remete, em parte, a "nascer com" (cum-nascere). É na experiência que nasce o conhecimento. O conhecimento não adquire sentido se não estiver relacionado às coisas humanas, ele é produzido em regiões do corpo onde o inteligível convive intimamente com o sensível.

Precisei ter vivido a maior parte da minha existência em instituições educativas, necessitei ter atuado como professora durante anos para me libertar do

${ }^{3}$ A noção de carne, segundo Merleau-Ponty, designa essa generalidade do sensível da qual tudo emerge, um sensível no duplo sentido daquilo que se sente e daquele que sente. Meu corpo e o mundo são feitos da mesma carne, a carne do meu corpo é participada pelo mundo, ambos se imbricam mutuamente (Merleau-Ponty, 2000, p. 225). 
escolacentrismo ${ }^{4}$, para relativizar a importância da escolarização na vida e entender que a educação escolar veicula apenas uma entre as muitas formas de aprender o mundo. Meus filhos me ensinaram isto, meus alunos me ensinaram isto, sobretudo os adultos iletrados. Eles frequentaram pouco a escola, mas são dotados de sabedorias, as mais profundas e diversificadas. Seus conhecimentos, geralmente não legitimados pela sociedade letrada, não foram ensinados nem aprendidos através de métodos, categorias ou linguagens que a escola ensina e valida.

Demorou, mas finalmente entendi que em educação não há um ponto de chegada para o aprendizado, nem mesmo um patamar a alcançar que seja igual para todos os alunos, aspectos que continuam norteando a cultura escolar e que se tornam verdadeiras obsessões para o corpo docente, traduzidos nos objetivos a serem atingidos e nas famigeradas expectativas de aprendizagem. Hoje, compreendo melhor quando Paulo Freire aponta o diálogo com o aluno como ação educativa essencial. Para mim, o diálogo deixou de ser estratégia pedagógica para tornar-se opção ontológica. A experiência me ensinou a substituir a questão: “o que vou ensinar hoje aos meus alunos?" para: "o que vou aprender hoje com meus alunos?".

\footnotetext{
${ }^{4}$ Termo cunhado por Ferreira-Santos (2011, p. 26).
} 
Aprender com o aluno é uma frase bastante usada e até banalizada nos discursos educativos. Mas, na realidade, o que ocorre de fato é que é muito difícil para um professor sair da posição de detentor da verdade. Nossa herança jesuítica é muito forte, ter a verdade e ter a missão de propagá-la constituem uma marca cultural da classe docente.

Não se trata apenas do reconhecimento da sabedoria dos iletrados. Para além da superficialidade desta consideração, fui movimentada em minha visão de mundo. Passei a enxergar no aluno o seu manancial, a ver que cada um deles não só tem uma história, como também é uma história. A metamorfose pela qual passei dentro da escola atuou como um forte ensejo para a criação deste trabalho e deu corpo à vontade de conhecer mestres-artesãos do povo, aprender com eles e fazer reverberar suas vozes, enaltecendo-as.

No quebra-cabeça da memória, outra peça importante para o nascimento desta pesquisa foi o livro "A caverna", de José Saramago. Li e reli esse romance com vagar, saboreando-o em toda a sua extensão. Declamei em voz alta algumas passagens, para que não me abandonassem facilmente. O protagonista da história, o oleiro Cipriano Algor, mora na periferia de uma cidade, sobrevive do trabalho no torno, aprendido do pai que, por sua vez, aprendera com o avô. 
Cipriano é viúvo, mora com sua filha Marta, que também trabalha com o barro, e com o genro Marçal Gacho. Um dos pontos altos do romance é a amorosidade e a relação respeitosa entre pai e filha, que se espraia ao genro, ao cachorro Achado e à vizinha Isaura Estudiosa. Os personagens são gente simples, pessoas do campo que sofrem com a expansão da industrialização e a substituição do trabalho artesanal pelo trabalho industrial. As louças de barro de Algor são preteridas em favor dos novos artefatos de plástico, o que não somente destitui-lhe o trabalho, mas também o seu lugar no mundo.

Cipriano Algor deitou a mão ao copo, bebeu de um trago o resto do vinho, e respondeu rapidamente, como se as palavras the queimassem a língua. Só me ficaram com metade do carregamento, dizem que passou a haver menos compradores para o barro, que apareceram à venda umas louças de plástico a imitar e que é isso que os clientes preferem. Não é nada que não devêssemos esperar, mais tarde ou mais cedo teria de suceder, o barro racha-se, esboicela-se, parte-se ao menor golpe, ao passo que o plástico resiste a tudo e não se queixa. A diferença está em que o barro é como as pessoas, precisa de que o tratem bem (Saramago, 2000, p. 33). 
A leitura deste livro despertou em mim regiões silenciadas, me possibilitou uma percepção mais ampla dos tempos em que vivemos, um entendimento de como os processos de globalização vêm promovendo o aniquilamento da pessoa, no sentido de prósopon, termo grego que significa "aquele que afronta com a sua presença". A noção de pessoa que afronta com a sua presença afirma um modo próprio de ser e de estar no mundo. Prosópon traz a marca pessoal da subjetividade, da transcendência, mas também traz a marca do mundo, do meio, do outro. Nas sociedades tradicionais, a pessoa é concebida na ideia de coletividade, ela situa-se entre a própria individualidade e a comunidade, entre a ancestralidade e o seu tempo de estar no mundo (Ferreira-Santos, 2010, p. 61).

Nesse sentido, fortemente influenciado pela mídia e o consumo que pregam o bem-estar individual, o cultivo do corpo, a competência e o sucesso pessoal, o sujeito contemporâneo, em sua busca incessante pelo relevo, é paradoxalmente achatado como pessoa, deixa de afrontar naturalmente com a sua presença para, em vão, tentar ser mais do que o outro.

Ah, bons dias, senhor Cipriano, disse ela, Venho cumprir o prometido, trazer-Ihe o seu cântaro, Muito obrigada, mas realmente não devia estar a incomodar-se, depois do que conversámos lá no cemitério pensei que não há grande diferença entre as coisas e as pessoas, têm a sua vida, 
duram um tempo, e em pouco acabam, como tudo no mundo, Ainda assim, se um cântaro pode substituir outro cântaro, sem termos de pensar no caso mais do que para deitar fora os cacos do velho e encher de água o novo, o mesmo não acontece com as pessoas, é como se no nascimento de cada uma se partisse o molde de que saiu, por isso é que as pessoas não se repetem, As pessoas não saem de dentro de moldes, mas acho que percebo o que quer dizer, Foi conversa de oleiro, não ligue importância aqui o tem, e oxalá não caia a asa a este tão cedo (Saramago, 2000, p. 62).

O livro problematiza de forma poética, sensível e visionária o lugar e o valor das culturas na atualidade, fazendo referência à grande obra de Platão. Cada vez mais concebemos a realidade nas aparências. Vivemos a olhar para telas, nossas paredes, e não nos viramos. A Caverna de Platão é aqui e aquelas pessoas vendo sombras somos nós.

O que eu acho é que nós nunca vivemos tanto na caverna de Platão, como hoje. Hoje é que estamos a viver, de fato, na caverna de Platão. Porque as próprias imagens que nos mostram a realidade estão expostas de uma maneira que substituem a realidade. Nós estamos num mundo que chamamos mundo audiovisual. Estamos, efetivamente, a repetir a situação das pessoas aprisionadas ou atadas à 
caverna de Platão: olhando em frente, vendo sombras e acreditando que essas sombras são a realidade. Foi preciso passarem todos esses séculos para que a caverna de Platão aparecesse, finalmente, num momento da história da humanidade, que é hoje. E vai ser cada vez mais. (Depoimento de Saramago em Janela da Alma, 2001).

$\mathrm{Li}$ "A caverna" como quem bebe leite morno antes de dormir, sorvendo-a. Alguns anos mais tarde, movida por uma vontade ancestral, fui ao encontro do barro. Em 2007, após ter concluído o mestrado, comecei a fazer aulas de cerâmica no ateliê de Sirlene Giannotti. Unir-me ao barro foi decisivo para o resto dos meus dias.

Sempre utilizei o barro como material nas minhas aulas. Como matéria, ele é democrático, possibilita a modelagem e a construção de formas a quem não possui muita intimidade com ele. Algumas pessoas sentem repulsa pelo barro, mas são poucas. A maioria gosta, muitos adoram, principalmente as crianças. Grande parte dos alunos adultos, por sua origem rural, já experimentou modelar o barro na infância e o reencontro com ele na escola possibilitava uma expressão artística mais fluente e orgânica, resultando em obras especialmente bonitas: carros de bois, pilões, bonecos e outros objetos que geralmente retratavam temas agrestes nordestinos e do interior do país. 
Nessas oportunidades, enquanto os alunos modelavam, invariavelmente, eu mantinha um pedaço de argila nas mãos. Desde pequena, gosto do contato com o barro e a sala de aula constituía, até então, o único lugar onde eu me encontrava com ele. Às vezes, timidamente, construía alguma peça, ou ajudava o aluno a estruturar a sua. Na posição de professora, sentia que minha expressão poderia fazer frente à do aluno e inibi-lo. Tinha bastante cuidado com esse aspecto.

O barro, aos poucos, tomou conta da minha vida.

Experimento constantemente $o$

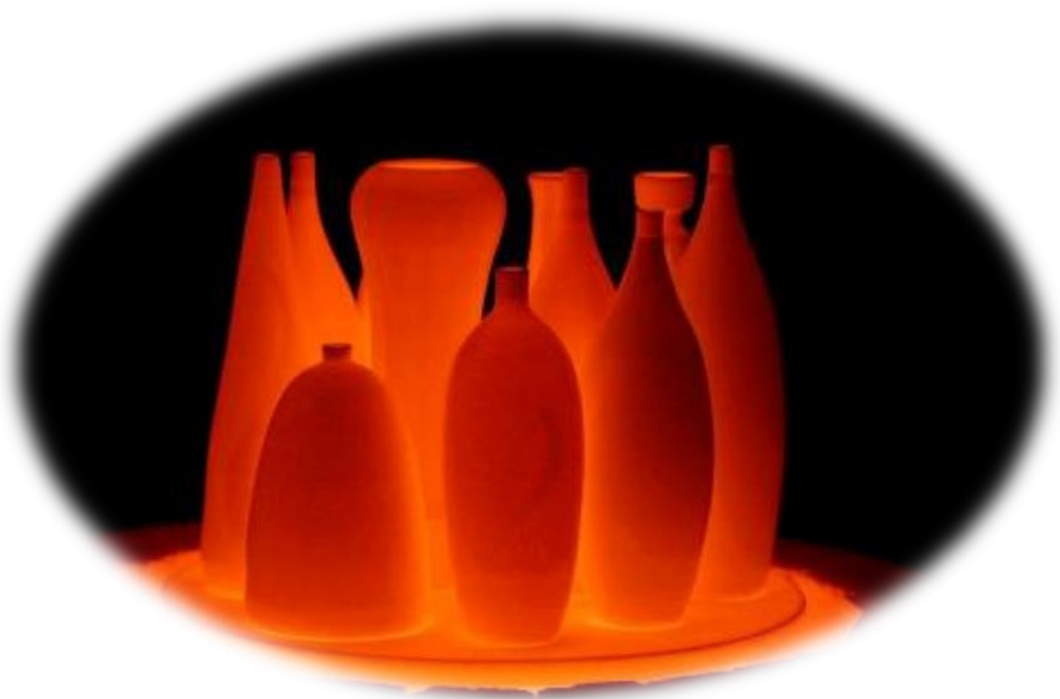

Peças incandescentes na queima Raku (Foto: Sirlene Giannotti) desejo de que passe a ocupar as vinte e quatro horas do meu dia. Quando sento ao torno, especialmente, estabeleço um diálogo com o barro que nunca alcancei 
com matéria alguma. Continuamente, sonho com as peças que estou produzindo e com a prazerosa sensação tátil que o barro provoca.

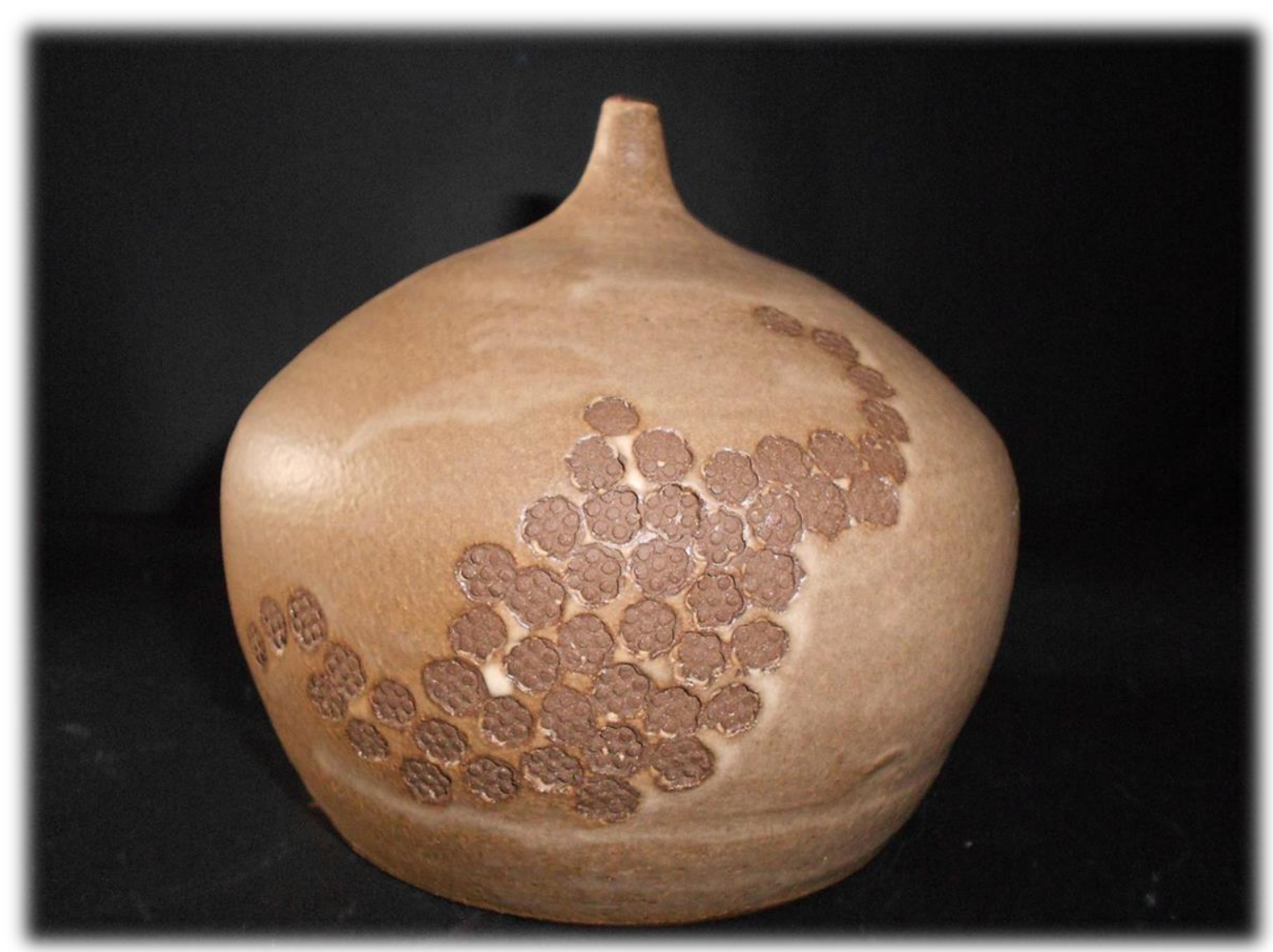

Vaso torneado em argila, Sonia Carbonell, 2013 
Meu aprendizado no torno se deu tarde, perto dos cinquenta anos. Posso dizer que foi a coisa mais difícil que aprendi na vida. Na realidade, ainda estou aprendendo e quando me confronto com mestres oleiros, percebo que sei muito pouco. Tornear vem custando-me muita paciência e perseverança, várias vezes achei que nunca conseguiria centralizar uma peça ao torno, experimentei inseguranças e sentimentos de derrota. Nessa adversidade da resistência, uma força interna me fazia prosseguir, minha maturidade anunciava que, apesar das dificuldades, conquistaria saberes profundos e significativos, que as dores musculares, a imperícia das mãos, a impaciência eram obstáculos a serem superados:

Quando se é jovem e de mente estreita, pretende-se que o texto ou o desenho concretizem uma ideia pré-concebida, quer se dar à ideia uma forma instantânea e precisa. Graças a uma capacidade crescente de tolerar a incerteza, o vago, o indefinido e o impreciso, o momentaneamente ilógico e de caráter aberto, aprendemos gradualmente a habilidade de cooperar com o nosso próprio trabalho e permitir que este faça suas sugestões e tome seus rumos e movimentos inesperados. Em vez de impor uma ideia, o processo de pensamento se converte em um ato de espera, de escuta, de colaboração, de diálogo. 0 trabalho se transforma em uma viagem que pode levar-nos a lugares e 
continentes que nunca visitamos antes de deixarmo-nos guiar pelas nossas mãos, nossa imaginação e nossa própria atitude composta de vacilação e curiosidade (Pallasmaa, 2012, p. 125).

Meus alunos adolescentes riam quando eu thes dizia que precisavam aprender a ouvir a voz do barro. No entanto, posso afirmar que depois de muito amassar, tornear, dobrar, bater, alisar, riscar, furar, arredondar, puxar, acariciar, enfim, modelar essa massa úmida da terra, por vezes, sinto um sopro leve que roça a minha pele. Então, ouço com as mãos uma fala fraca que emana da argila úmida, disforme, e que balbucia o que deseja vir a ser.

Sirlene, minha mestra, costumava dizer: "o barro volta à forma antiga, ele tem memória!", "o barro gosta assim!", “o barro reclama, está vendo?". Hoje compreendo melhor estas afirmações. O barro parece dócil aos iniciantes, mas aos poucos descobrimos que ele não se submete aos nossos gestos com passividade. Quando o tocamos, responde diretamente às nossas mãos, às vezes reclama e não corresponde, às vezes gosta e se deixa levar. O barro impõe uma forma a quem quer formá-lo e, por fim, acaba por formar a própria pessoa.

"Dar forma é formar-se" (Giannotti, 2008). Ostrower ajuda a aclarar esta ideia: 
Daí se nos apresenta outro aspecto que tanto nos fascina no mistério da criação: ao fazer, isto é, ao seguir certos rumos a fim de configurar uma matéria o próprio homem com isso se configura. Quando vemos uma jarra de argila produzida há cinco mil anos por algum artesão anônimo, algum homem cujas contingências de vida desconhecemos e cujas valorizações dificilmente podemos imaginar, percebemos o quanto este homem, com um propósito bem definido de atender certa finalidade prática, talvez de guardar água ou óleo, em moldando a terra, moldou a si próprio. Seguindo a matéria e sondando-a quanto à 'essência do ser' o homem impregnou-a com a presença de sua vida, com a carga de suas emoções e de seus conhecimentos. Dando forma à argila, ele deu forma à fluidez fugidia de seu próprio existir captou-o e configurou-o. Estruturando a matéria também dentro de si ele se estruturou. Criando ele se recriou (Ostrower, 1987, p. 51).

Os ceramistas tradicionais japoneses, da região de Bizen, dizem que é preciso fundir-se totalmente com a matéria e deixar que a forma germine dessa unidade, como consequência natural. Assim, o ceramista se transforma no barro que amassa e deixa revelar o homem que é (Nakano, 1989, p. 28). É isto: ao plasmar formas no barro, a Sonia vem sendo formada por ele. Eu sou o barro que modelo. 
Merleau-Ponty (1999, p. 71) afirma que as coisas são sensíveis e que o sentido de uma coisa a habita. $O$ sentido não se resume a uma ideia que organiza e ordena os aspectos sensíveis da coisa. Compreendi isto com o corpo quando comecei a desenvolver uma relação com o barro. É como se essa matéria contivesse o princípio de sua gênese. Ela é receptiva, mas também ativa, ela se mostra, revela seu ser pela própria organização de seus aspectos sensíveis. O barro é vivo: articula volume, espessura, temperatura, densidade, textura, movimento. Apreender o sentido do barro não é realmente um ato do espírito, mas um ato do corpo, como bem assinala Merleau-Ponty.

Desse modo, esta pesquisa de doutorado foi orientada pelo barro, mestre a quem descobri na maturidade: educador afável, flexível, que ternamente me instiga à busca por sentidos. De modo fenomenológico, o barro vem me ajudando a encontrar a essência das coisas por meio de sua existência, de sua materialidade. Mestre calado, exige que me cale para que possa escutar-lhe a voz tênue, para que logre sentir o seu breve alento sobre as minhas mãos.

O barro tem me formado, ele vai ser o meu próximo diploma. O barro dá eixo para a minha existência. Sou agradecida por tê-lo encontrado como canal expressivo aos 48 anos. Não foi um encontro de infância ou adolescência, foi um encontro de 
maturidade. A impressão que tenho é que vou modelar barro até ficar bem velhinha.

Um trabalho que jamais acabaria, isso era o que de mais bonito e atento ela já soubera; pois se ela podia fazer o que existia e o que não existia!

Clarice Linspector In: "Os bonecos de barro"

Por fim, vale salientar que desde que comecei esta pesquisa, meu ateliê converteu-se em escritório, pois meu dia-a-dia tem se alternado entre fazer cerâmica e estudar, modelar e ler, tornear e escrever: 


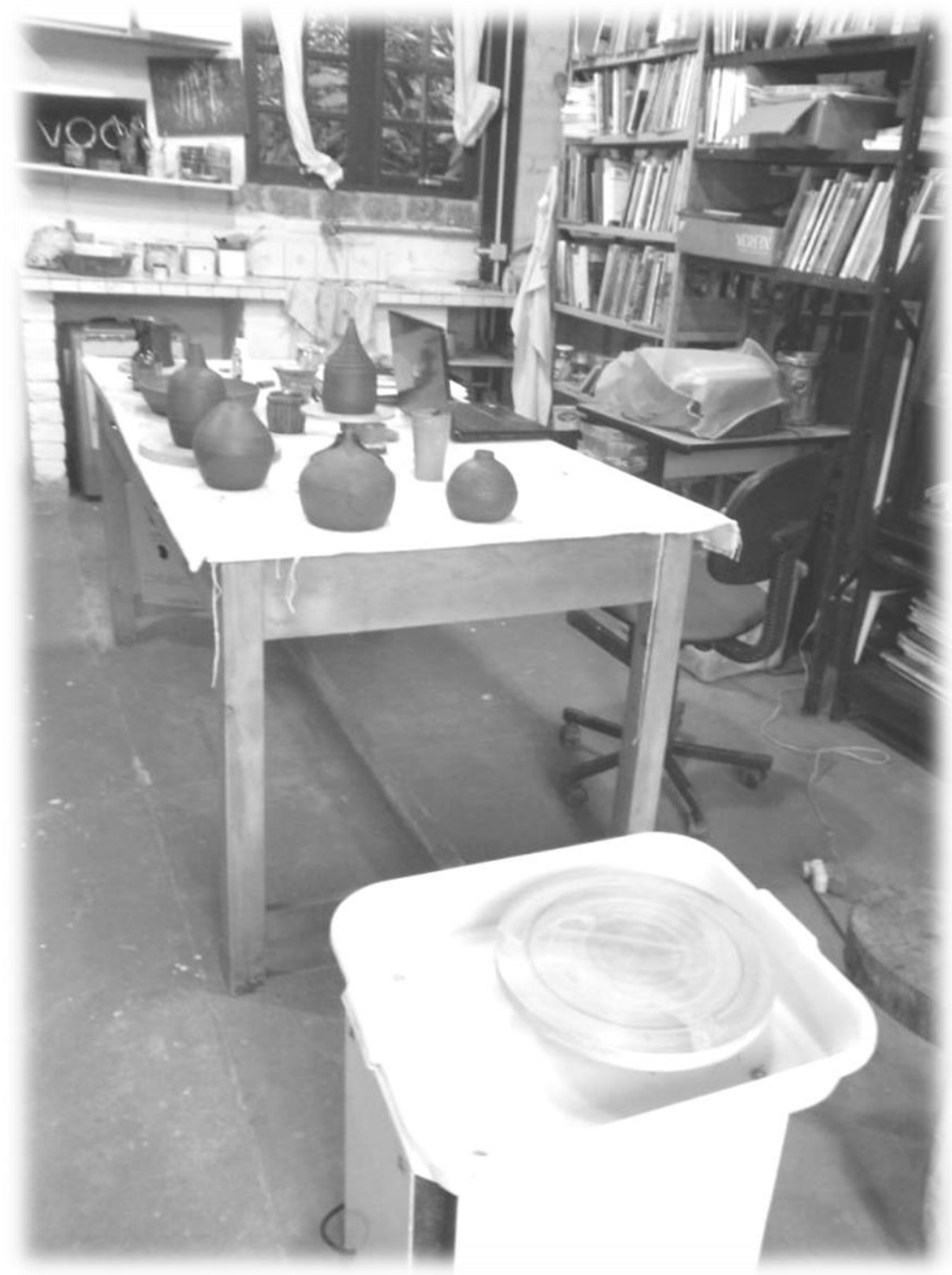

Meu ateliê-escritório, 2012 
58 
A ominosa visão das chaminés a vomitar rolos de fumo deu-lhe para se perguntar em que estupor de fábrica daquelas estariam a ser produzidos os estupores das mentiras de plástico, maliciosamente fingidas à imitação de barro.

É impossível, murmurou, nem o som nem o peso se lhe podem igualar, e há ainda a relação entre a vista e o tacto que li, não sei onde, a vista que é capaz de ver pelos dedos que estão a tocar o barro, os dedos que, sem lhe tocarem, conseguem sentir o que os olhos estão a ver. E como se isto não fosse já tormento bastante, também se interrogou Cipriano Algor, pensando no velho forno da olaria, quantos pratos, púcaros, canecas e jarros por minuto ejectariam as malditas máquinas, quantas coisas a fazer as vezes de bilhas e quartões. $O$ resultado destas e outras perguntas que não ficaram registradas foi ensombrar-se outra vez o semblante do oleiro e, a partir daí, o resto do caminho foi todo ele um contínuo cogitar sobre o futuro difícil que esperava a família Algor (...).

Saramago, 2000, p. 27. 


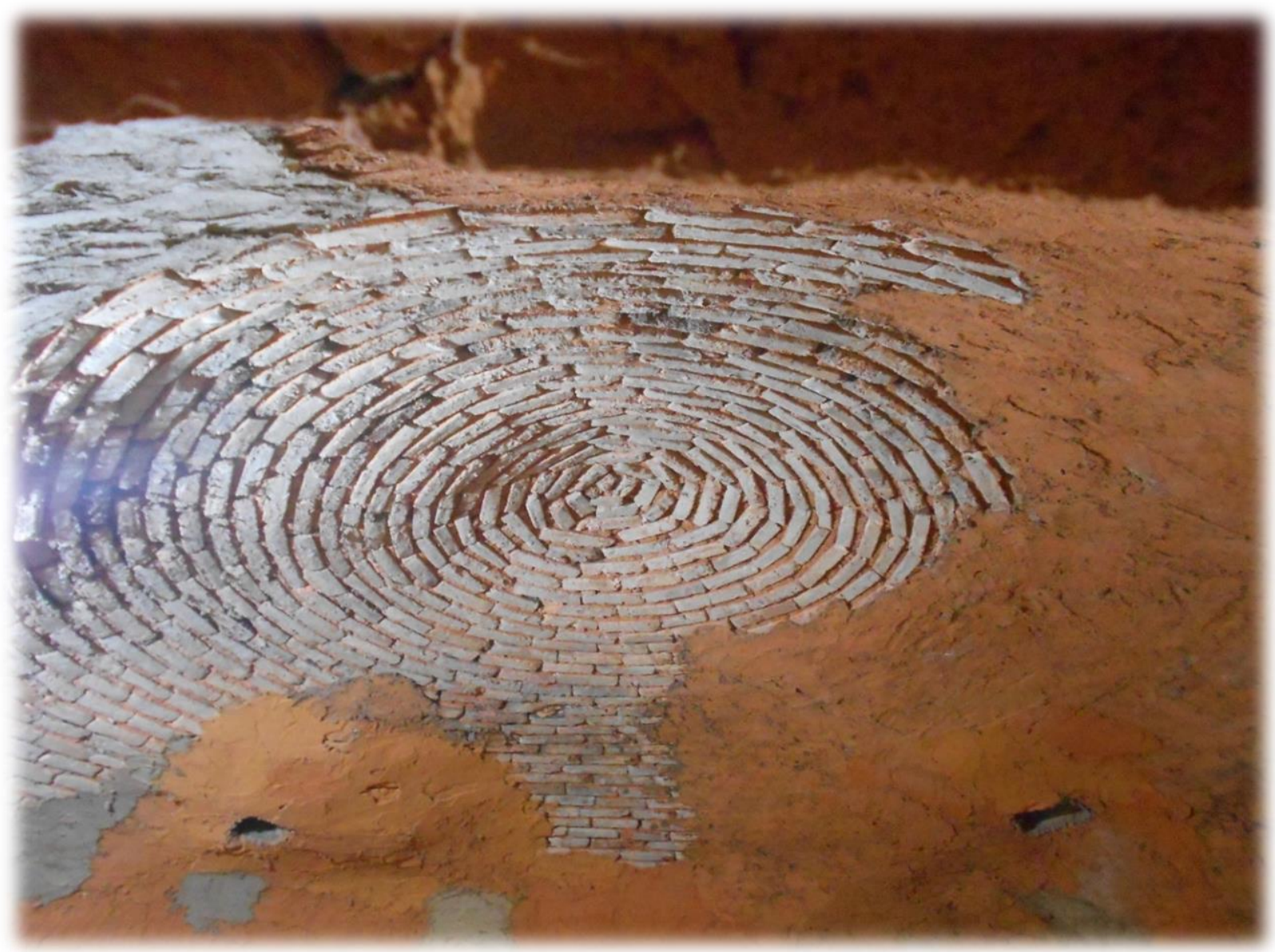

Teto de um forno de capela 


\section{RUMORES DE MARAGOGIPINHO}

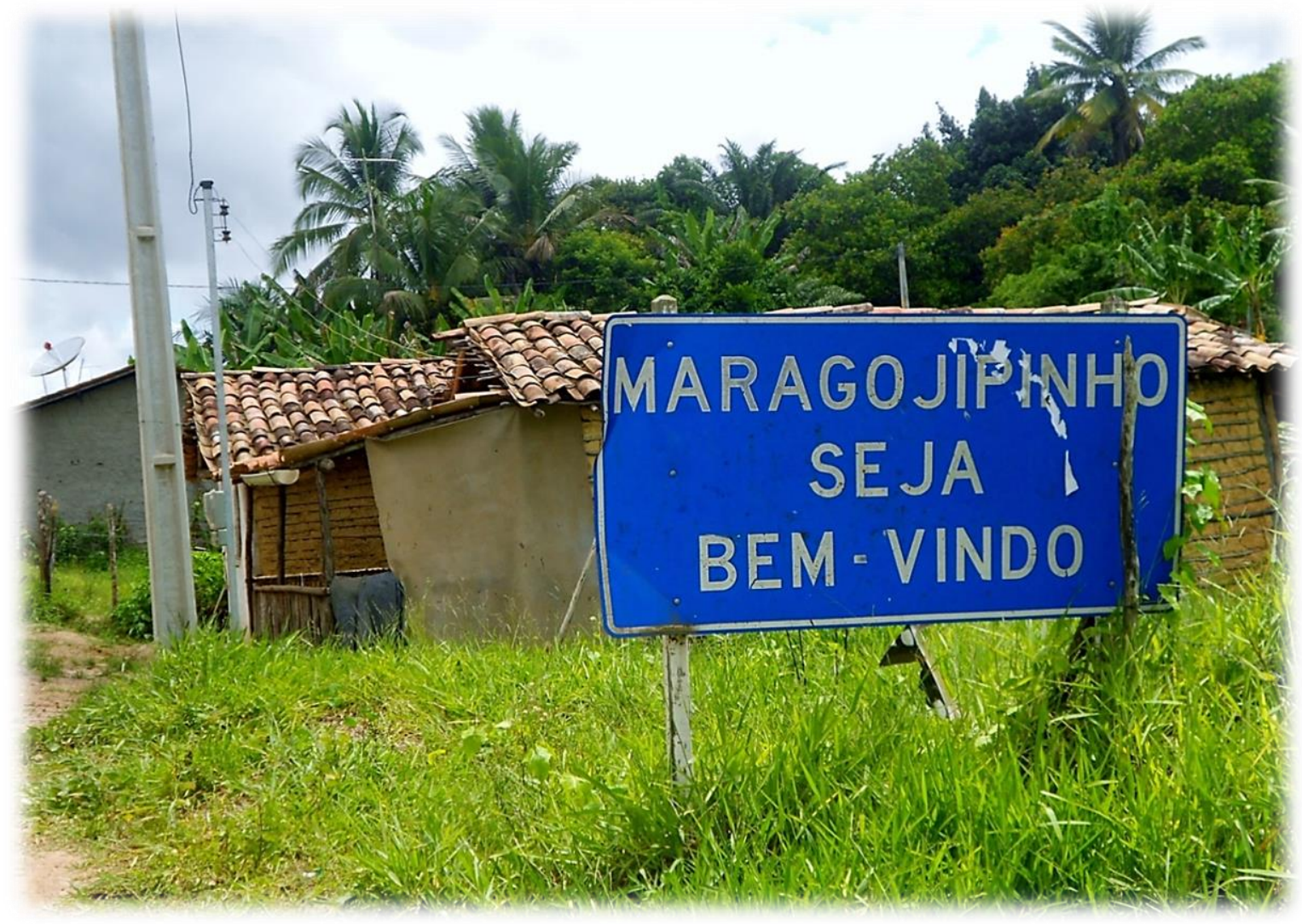

Placa na entrada do povoado 
Apesar da relevância da cerâmica no conjunto das manifestações da cultura material brasileira, ela não foi ainda suficientemente estudada. Há pouca bibliografia sobre o tema, há material mais abundante na área de antropologia. Meu contato diário com o barro tem sido determinante para nortear caminhos metodológicos e desvelar rastros a seguir. No universo das artes populares, em meio à multiplicidade de modalidades, técnicas e materiais, optei por investigar uma comunidade brasileira que vive do barro.

Depois de uma longa busca em livros, sites, blogs e vídeos, encontrei inúmeros povoados e até cidades inteiras em que as pessoas se dedicam a fazer cerâmica. No meio rural, é comum as mulheres modelarem o barro, enquanto os homens desenvolvem atividades mais diretamente relacionadas à sobrevivência, como a agricultura e a pesca. No entanto, existem lugares no interior em que somente os homens produzem peças de barro. Na vastidão deste Brasil, me foi bastante difícil escolher onde realizaria a pesquisa, pois não conhecia de perto nenhum desses sítios e todos eles, virtualmente, emanavam aspectos de riqueza cultural e de possível fertilidade para uma investigação. Ao final, elegi o povoado de Maragogipinho, distrito da cidade de Aratuípe, na Bahia. 
A primeira razão que me levou a escolher Maragogipinho é que lá tanto os homens quanto as mulheres trabalham com barro; uma peça é construída por, no mínimo, quatro mãos. Os homens são oleiros, confeccionam os artefatos em tornos movidos com os pés, enquanto as mulheres produzem o acabamento, dão polimento e pintam. Encantei-me com esta constatação, não havia encontrado nenhuma outra comunidade onde a produção de cerâmica fosse compartilhada por homens e mulheres.

A segunda razão da escolha foi o apuro estético das obras, a beleza das formas torneadas, a delicadeza das pinturas, em que transparece o esmero dos artesãos e artesãs. Grande parte da produção é de peças utilitárias grandes e pequenas, mas fabricam também cerâmica figureira: bonecas, animais, cenas do cotidiano. A cerâmica de Maragogipinho é tradicionalmente pintada com corantes feitos do próprio barro. São utilizadas como tintas a tabatinga e o tauá. A tabatinga é um engobe ${ }^{5}$ branco e o tauá um engobe vermelho ou amarelado. Essa técnica de pintura com o fundo vermelho e os motivos em branco, ou vice-versa, é muito antiga. O povo diz que é herdada dos índios e que vem passando de geração em geração.

5 Engobe consiste numa tinta feita do próprio barro, é a mistura de argila com água, de consistência cremosa (como a de um iogurte líquido), à qual se pode acrescentar óxidos corantes e/ou pigmentos para produzir variadas tonalidades. 
O terceiro motivo que me fez escolher o povoado de Maragogipinho é sua localização no Recôncavo Baiano, região de vasta riqueza cultural, de tradições, de muita história e histórias. O Recôncavo corresponde à extensa área em torno da Baía de Todos os Santos, inclui a capital Salvador e não só o litoral, mas também o interior. O termo Recôncavo foi dicionarizado como brasileirismo e significa extensa e fértil região da Bahia. Sobre seus solos de massapê, uma terra preta argilosa, prosperaram outrora fazendas imponentes de lavoura de cana-de-açúcar, onde o senhorio fundiário fincou raízes profundas. Para a produção açucareira, o Recôncavo recebeu milhares de escravos, o que originou um alto grau de ancestralidade africana na região.

Há ainda uma quarta razão para fixar minha pesquisa na Bahia, essa de natureza afetiva. Durante o tempo em que fui professora de adultos na cidade de São Paulo, convivi intensamente com migrantes desse estado, praticamente oitenta por cento dos meus alunos eram baianos. Cultivo admiração e reverência por esse pessoal, seu sotaque é música para os meus ouvidos. Além da alegria, que é uma marca cultural predominante no povo baiano, eles são, em sua maioria, receptivos e amorosos. 


\section{1. $O$ povoado}

Fiz, ao todo, duas viagens a Maragogipinho: em março de 2013 e em janeiro de 2015, via Salvador. Na primeira viagem, registrei em meu caderno as impressões que tive ao conhecer Maragogipinho. Naquele dia, da janela do avião, com os olhos ofuscados pelo reflexo do sol na água, enxerguei o mar verde da Bahia, volumoso, contornado pelo continente do Recôncavo e pelas praias da llha de Itaparica. No chão, o caminho que me levou ao povoado descortinou uma bela paisagem rural, típica nordestina: coqueiros, jegues pastando, alguns bois deitados no campo e casas de pau-a-pique. $O$ carro alugado percorreu as curvas da estrada que beira o mangue do Recôncavo Baiano, território que avistei de cima e que se corporificou ali, diante de meus olhos, ampliado, em toda a sua exuberância. Respirei um ar cálido, o dia era limpo e o sol escaldante. Estava na Bahia!

Doze quilômetros antes de chegar à Maragogipinho, em um trevo, enxerguei as primeiras pistas do que buscava. Vi grandes peças de cerâmica no meio de canteiros de flores: potes, vasos, talhas, duas bonecas e um boi, distribuídos cuidadosamente nos dois lados da estrada, anunciando que logo acharia o povo que vive do barro. 
66 


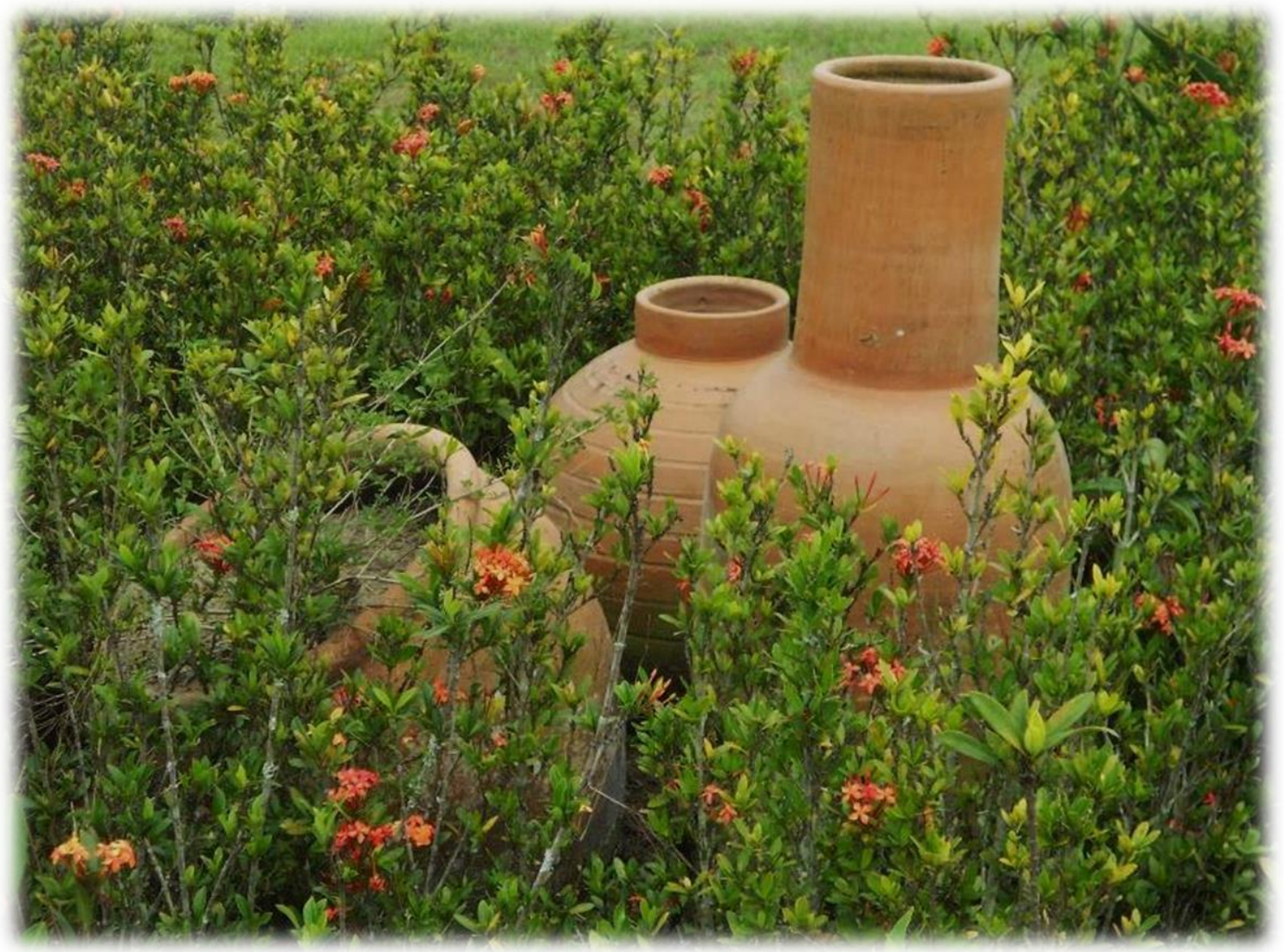

Trevo de entrada para Maragogipinho 


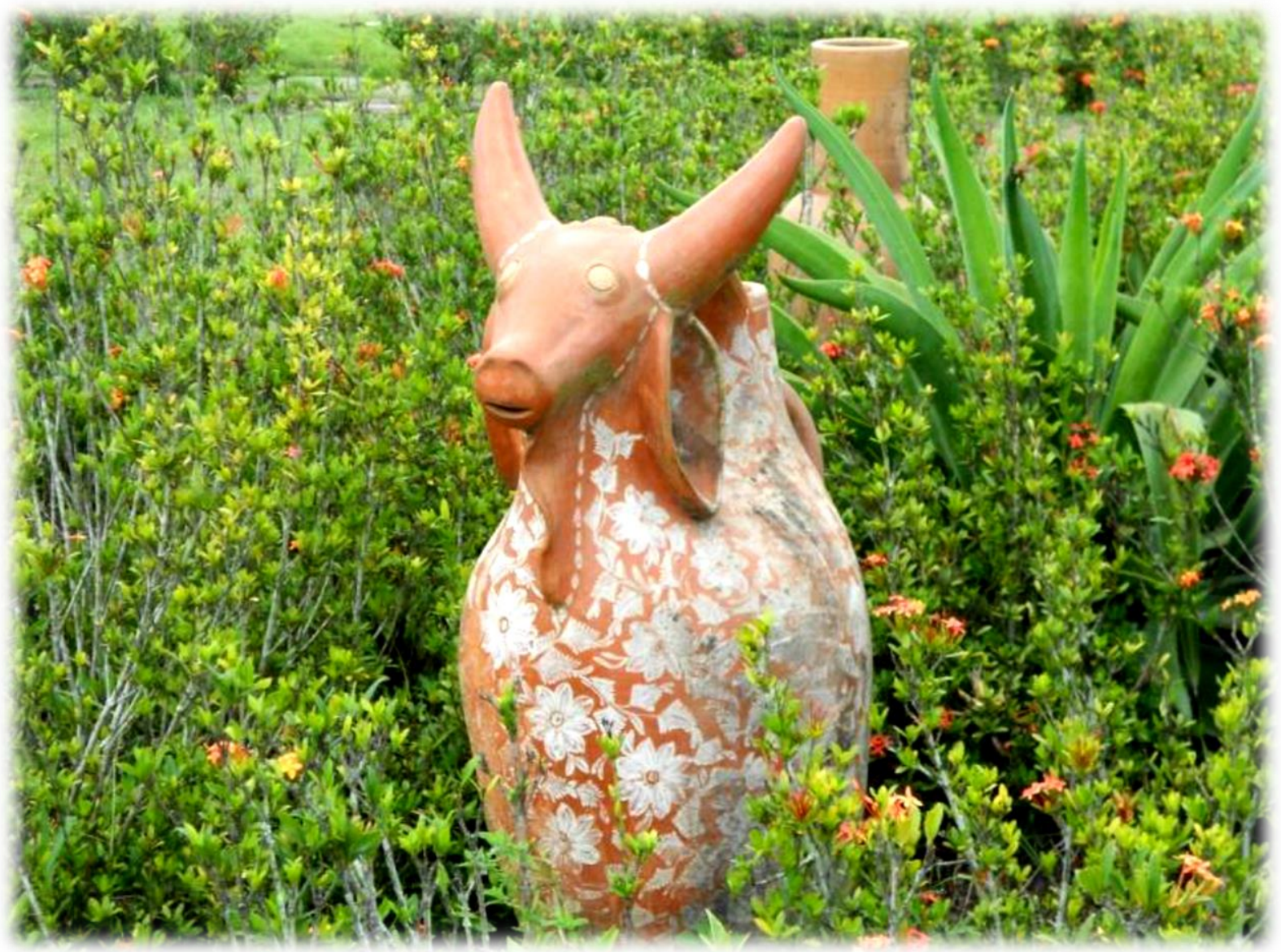

Trevo de entrada para Maragogipinho 
Quinze minutos depois, avistei casarios coloridos e algumas casas de pau-a-pique. As poucas vias principais calçadas e as ruazinhas de terra traduziam a singeleza de Maragogipinho. Algumas pessoas paravam para olhar o carro, curiosas, sem reconhecer a motorista. No alto de uma colina, passei por uma pequena igreja barroca com as paredes descascadas, que ofereceu indícios da antiguidade do lugarejo. Estacionei para explorar o lugar a pé, conhecê-lo de perto.

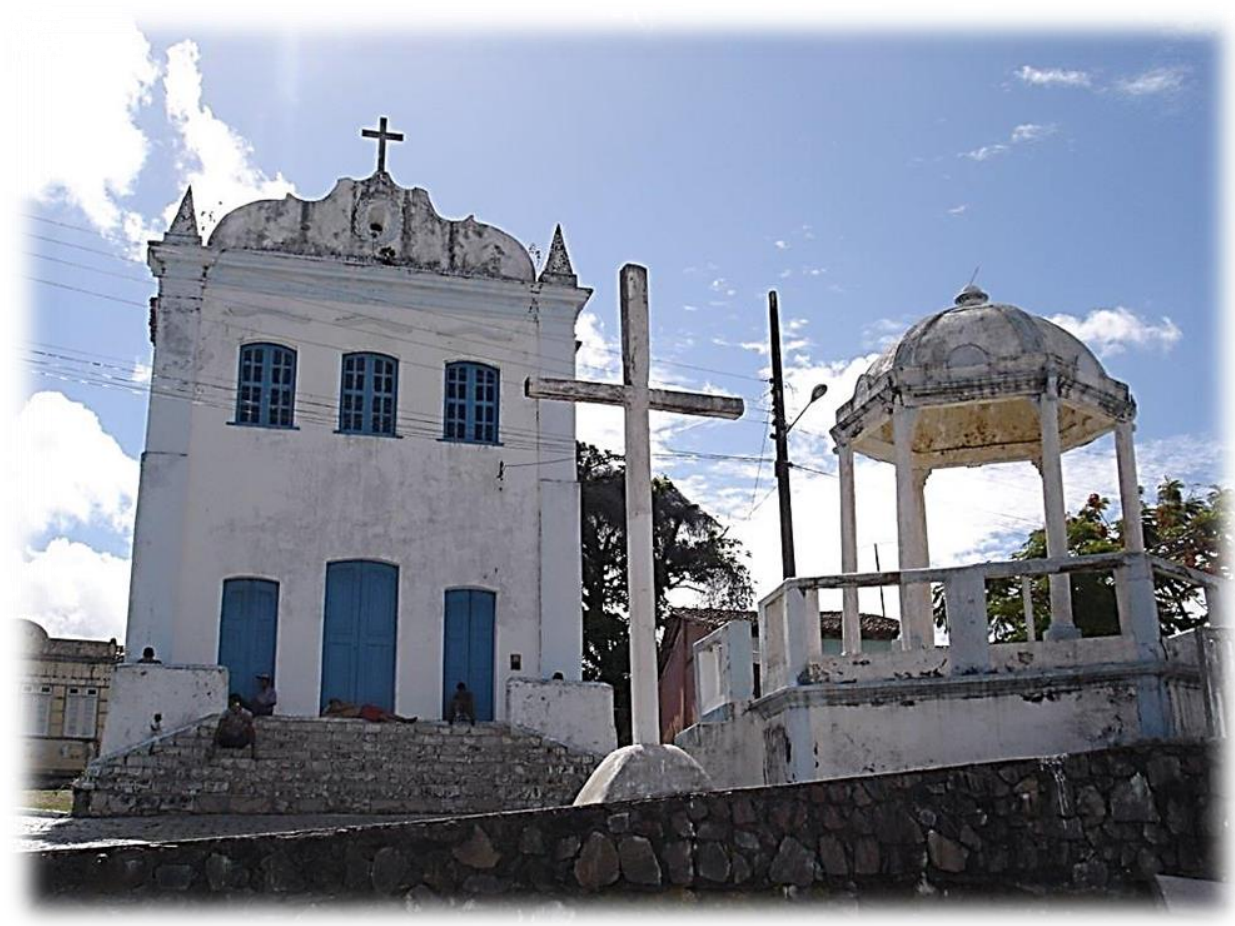

Igreja Matriz Nossa Senhora da Conceição

(http://www.panoramio.com/photo/30564120) 


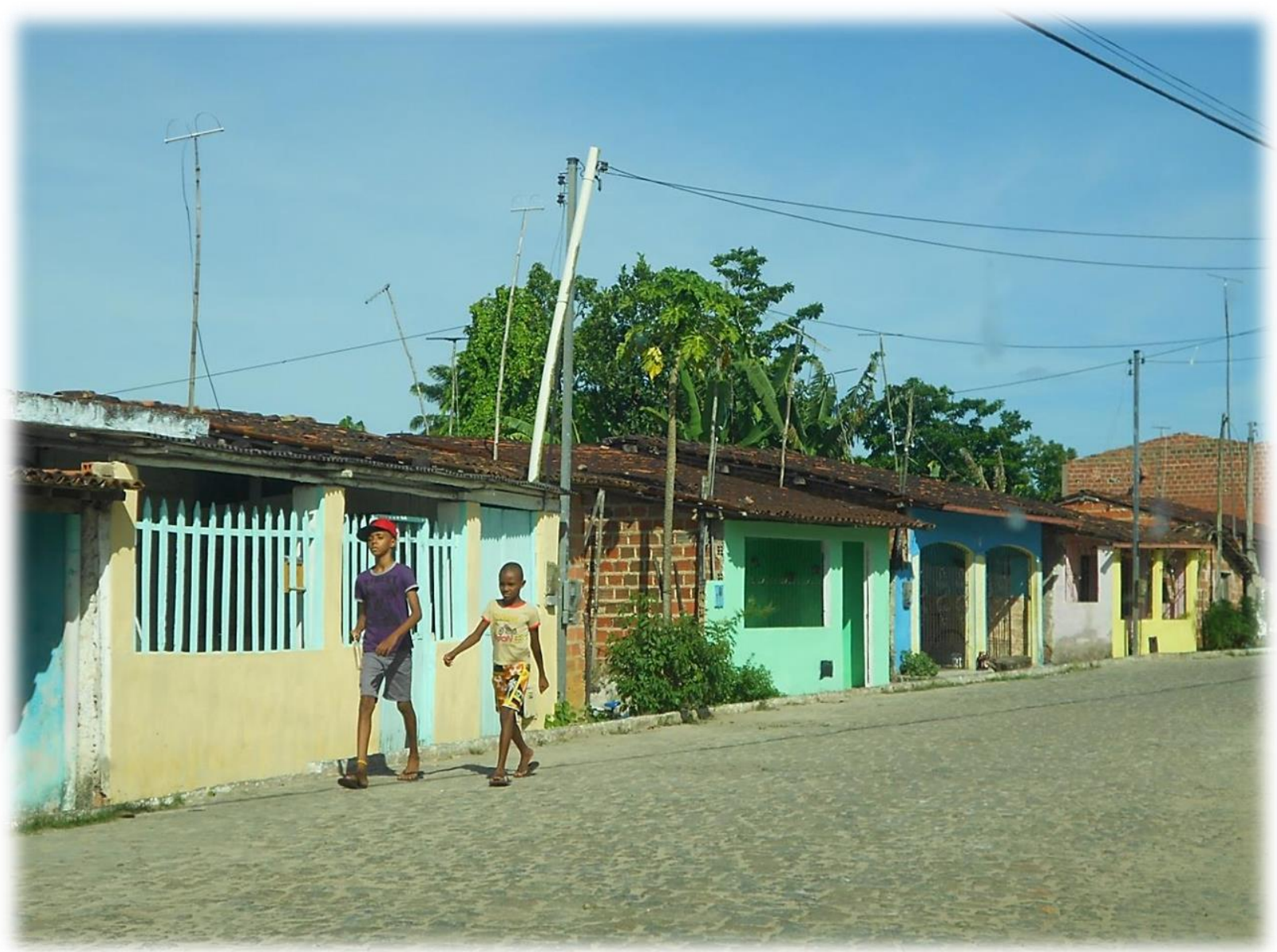

Rua de Maragogipinho 


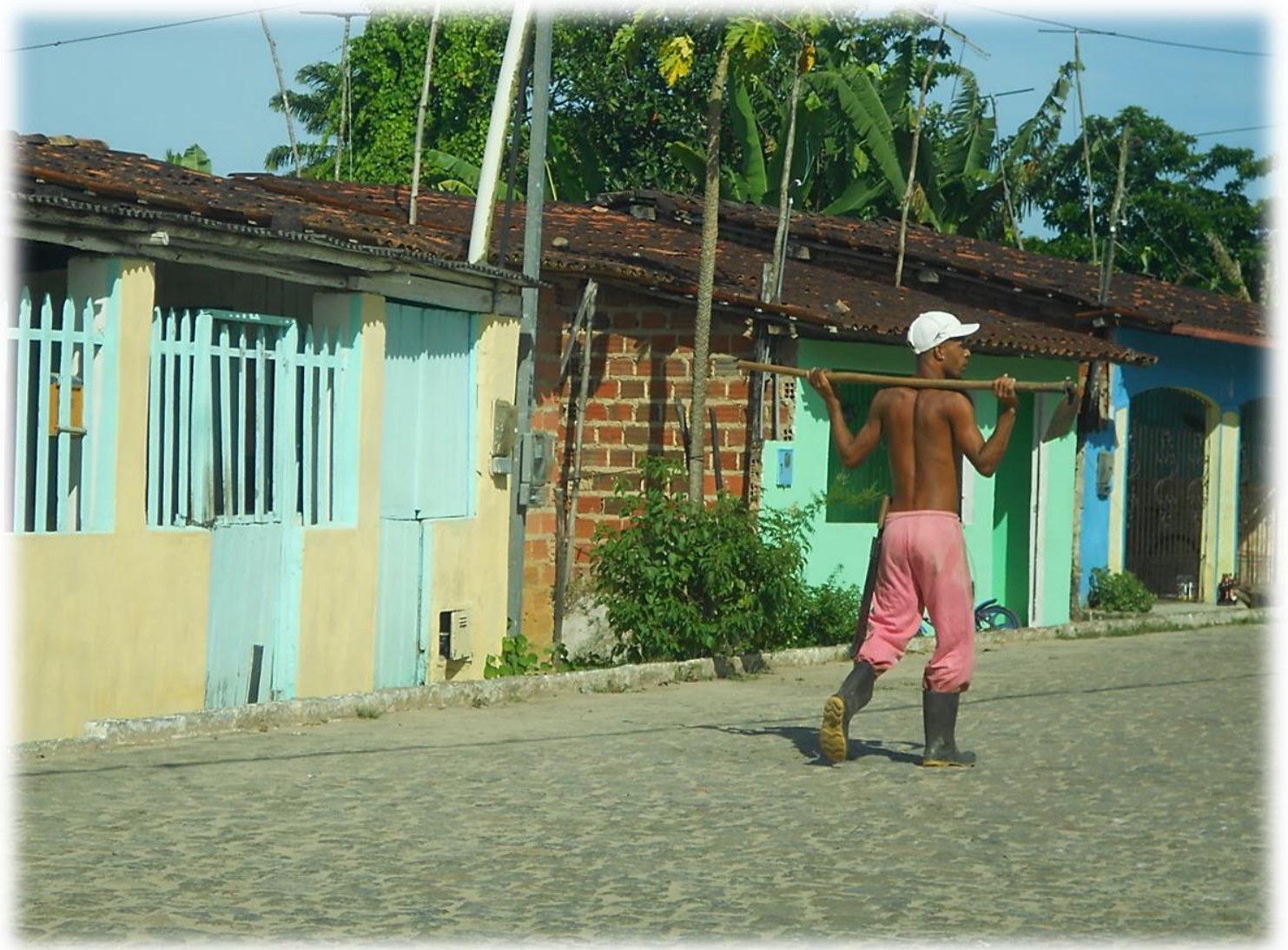

Rua de Maragogipinho 


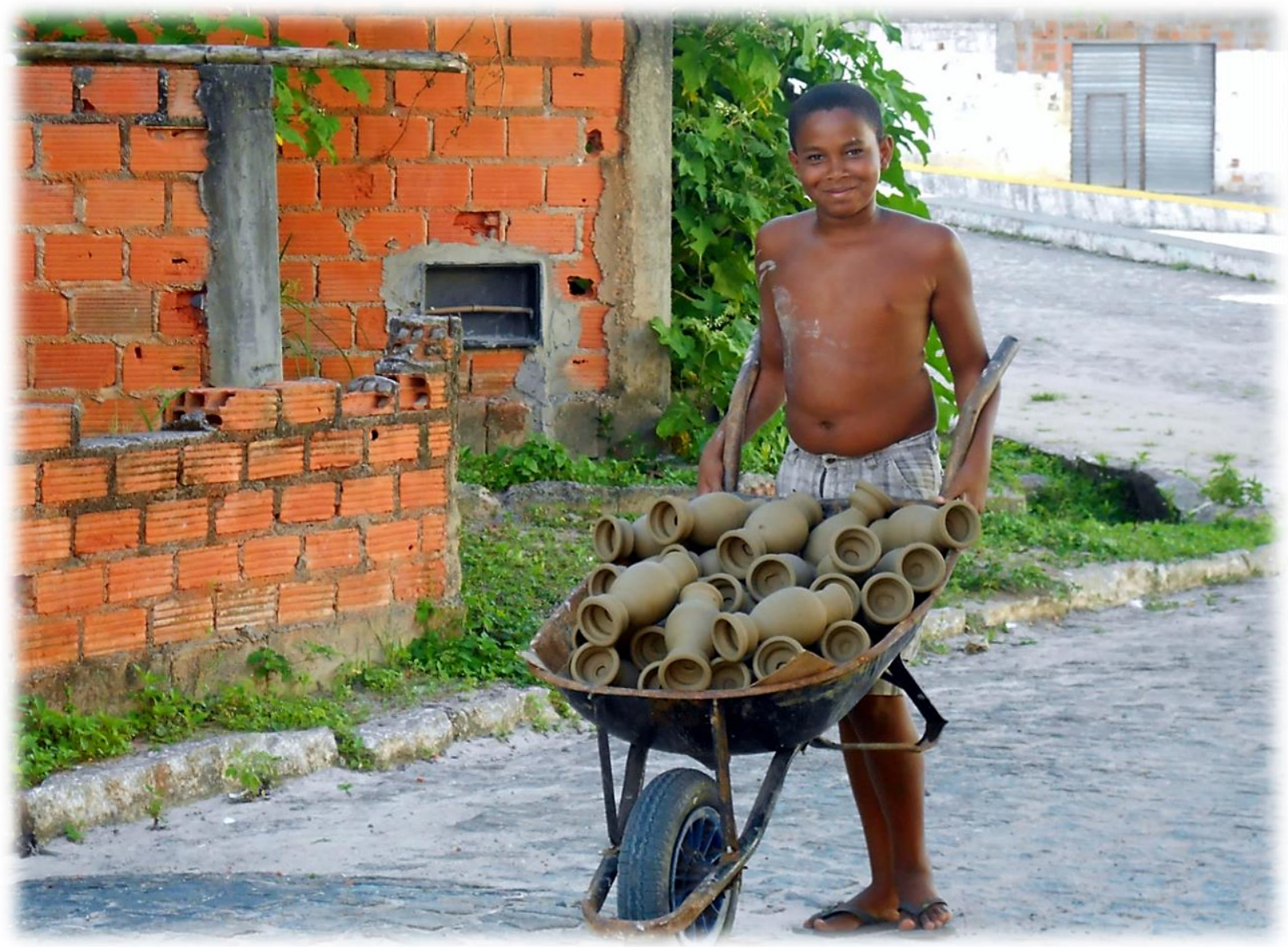

As boas vindas pelo menino transportando peças para a casa da pintora 


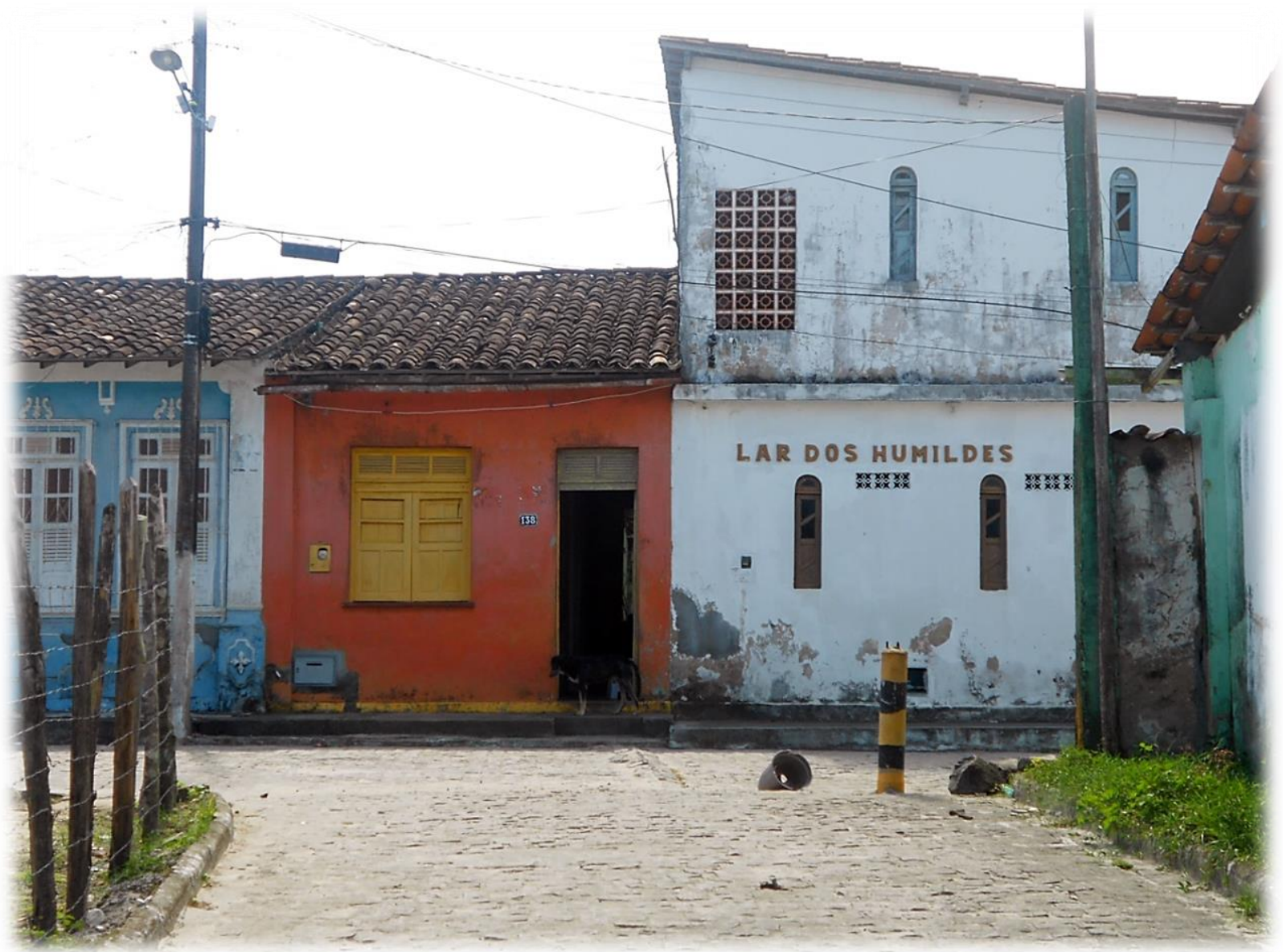

Rua de Maragogipinho 


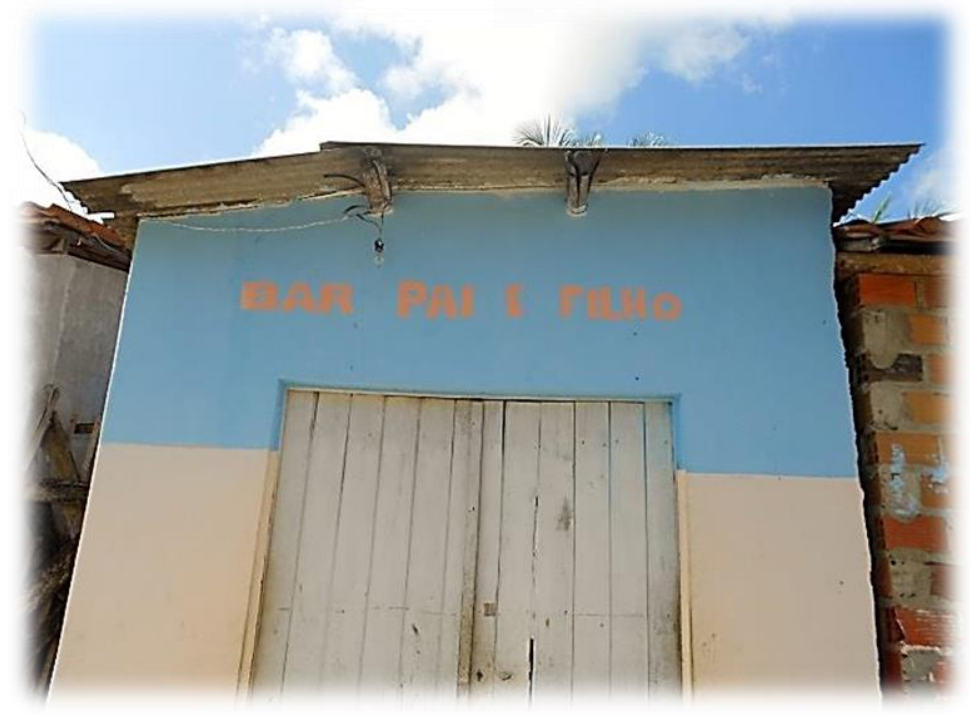

Bar

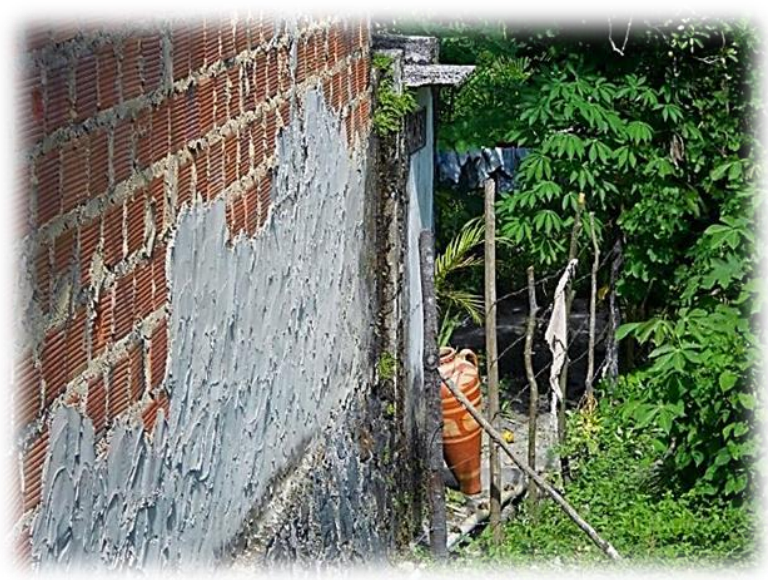

Fundos de uma casa 


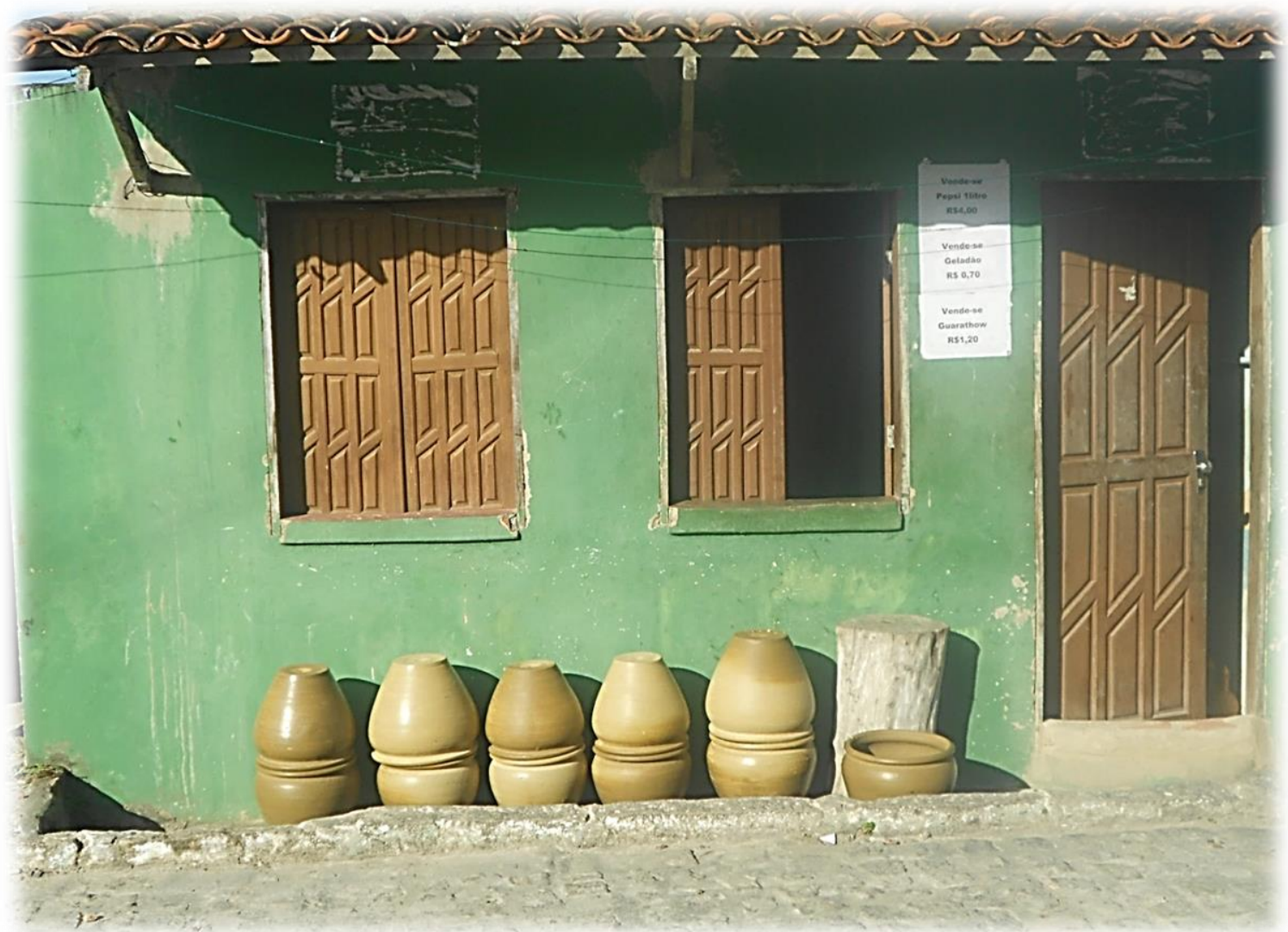

Fachada de uma casa 


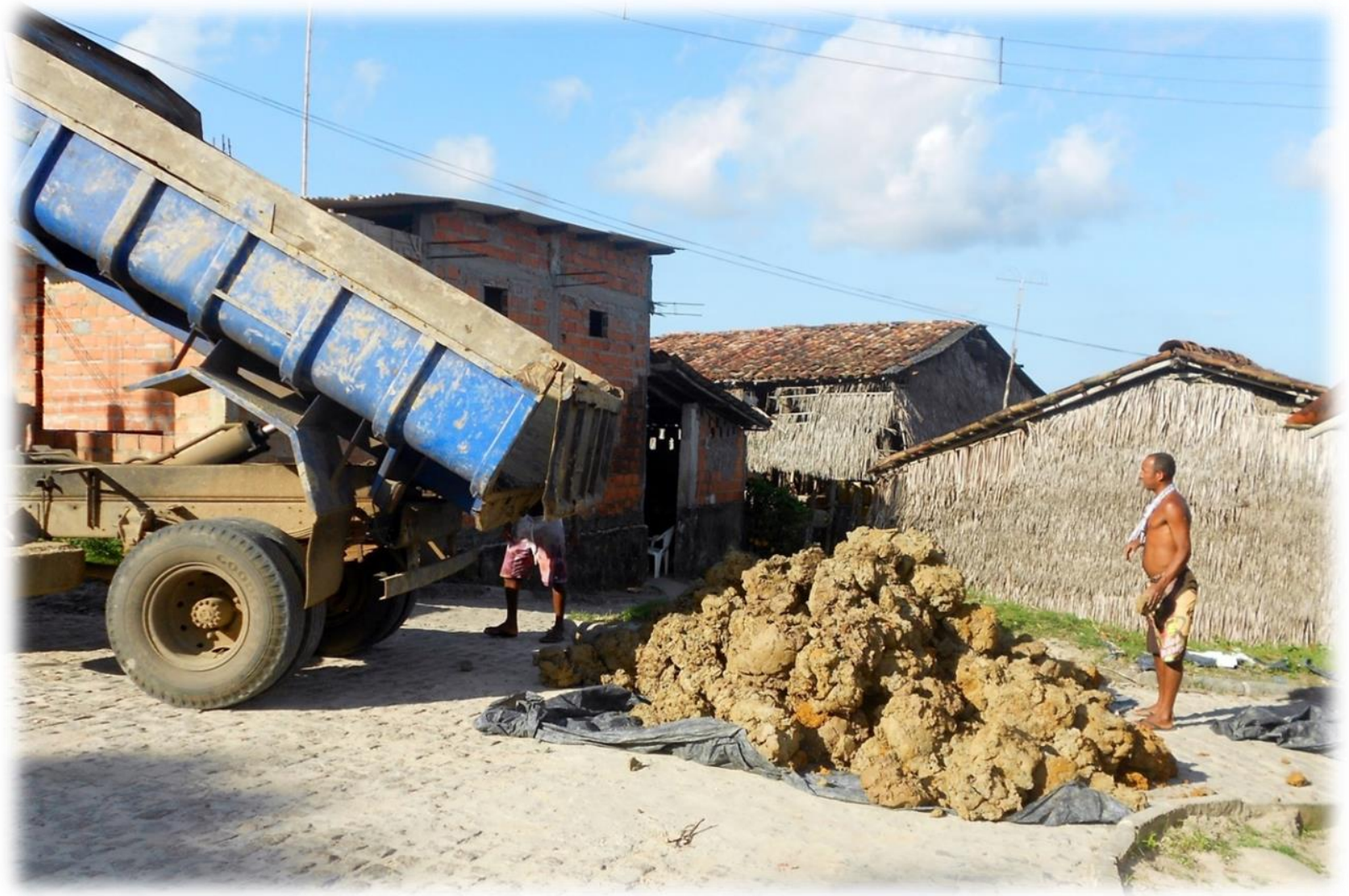

Chegada do barro 


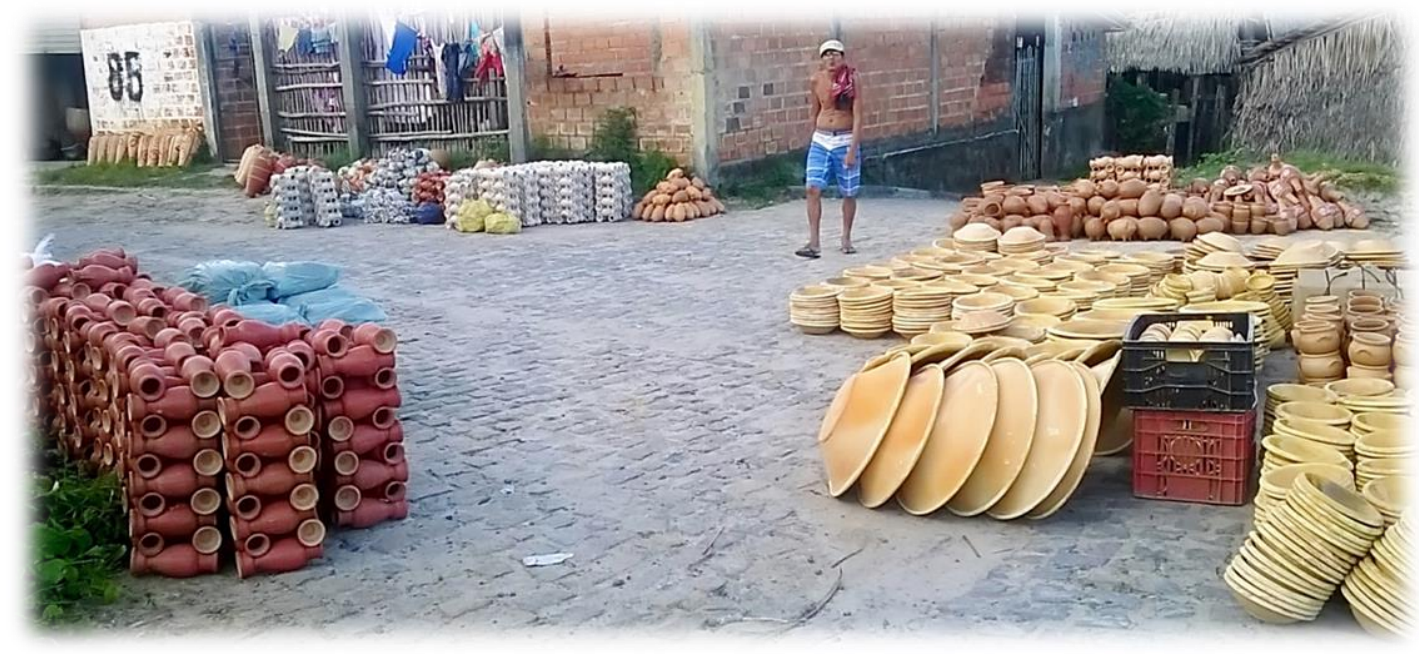

Peças prontas esperando pelo caminhão de transporte (oleiro Zé Curu ao fundo) 


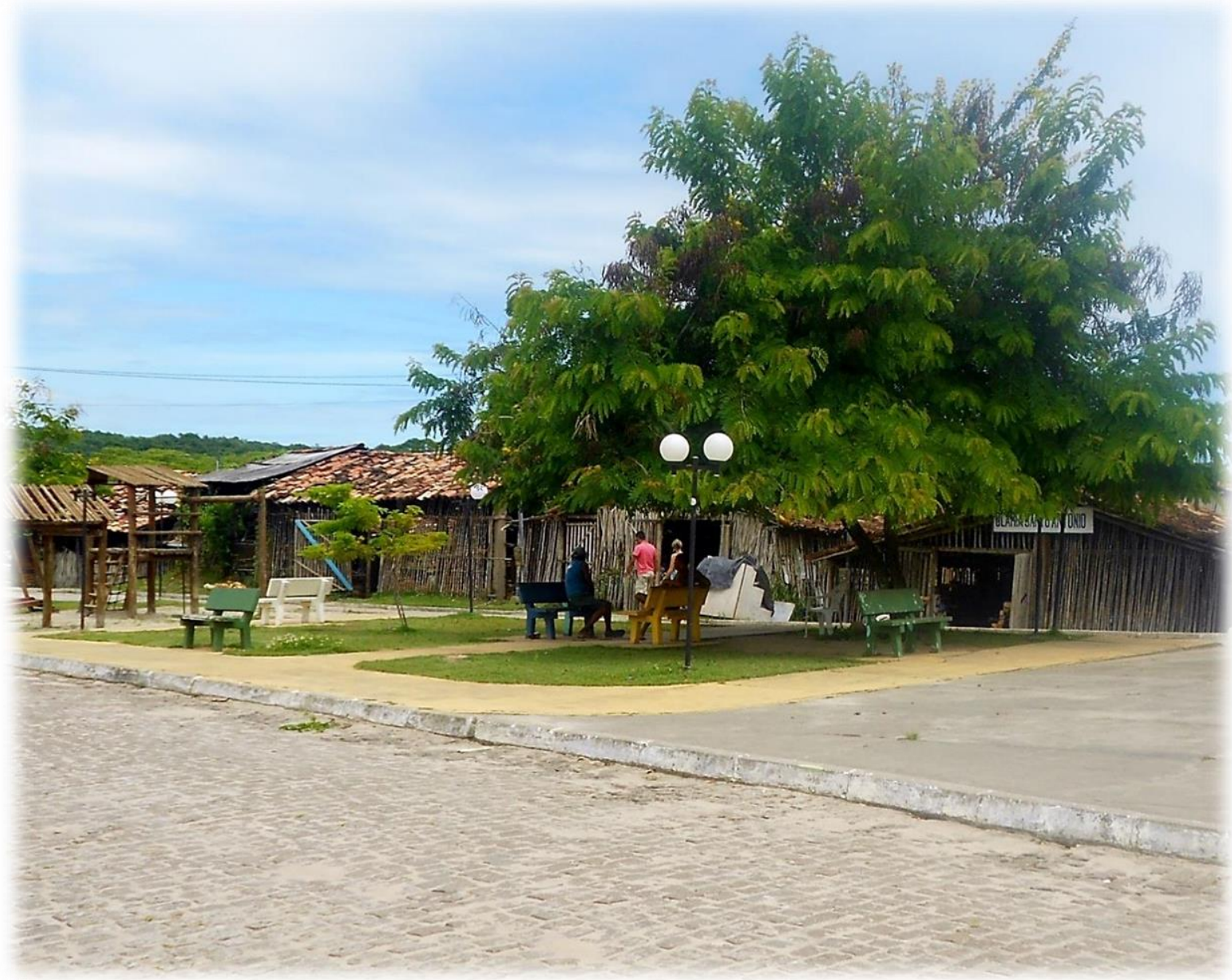

Praça principal com olarias 


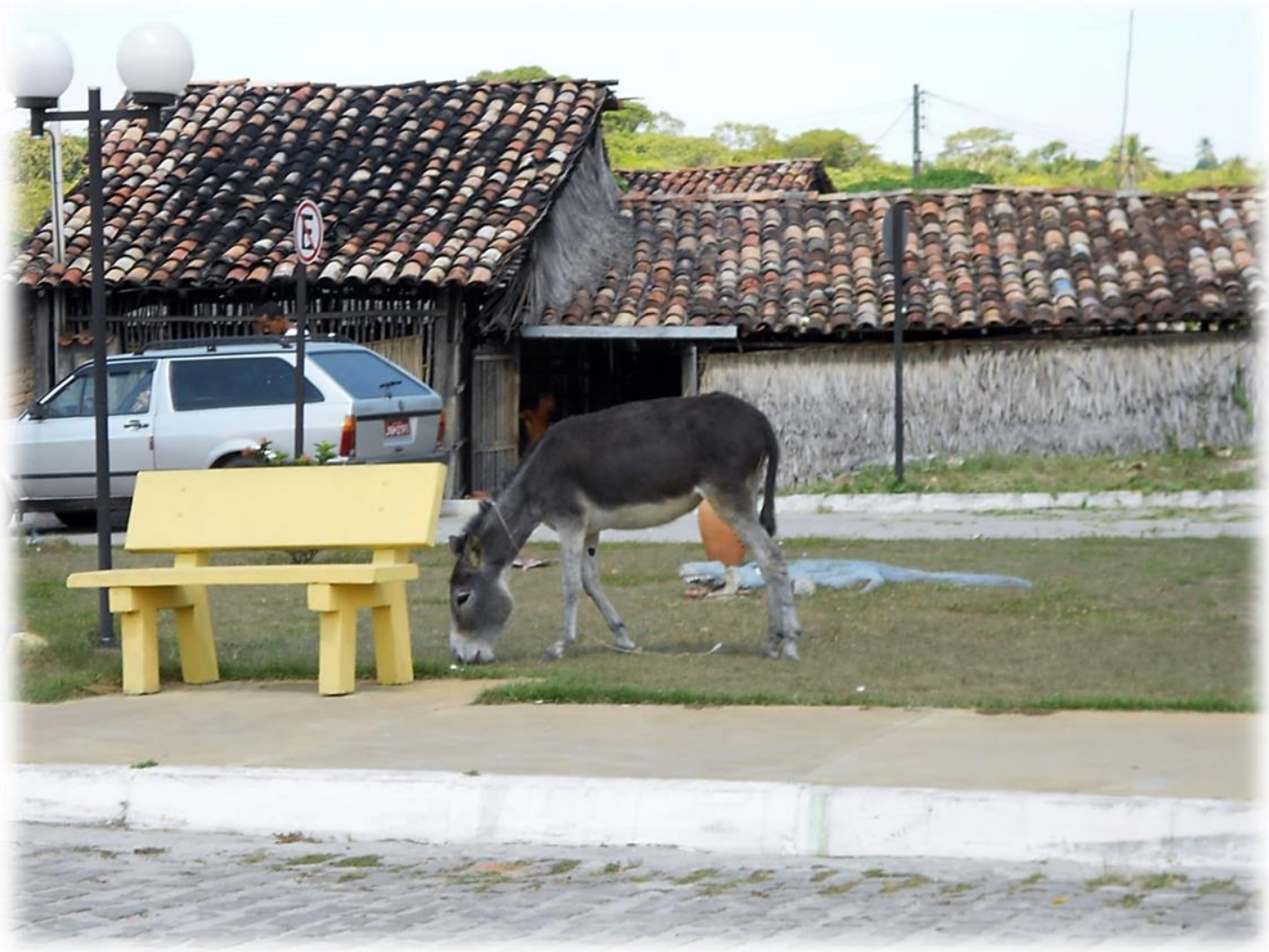

Praça principal 


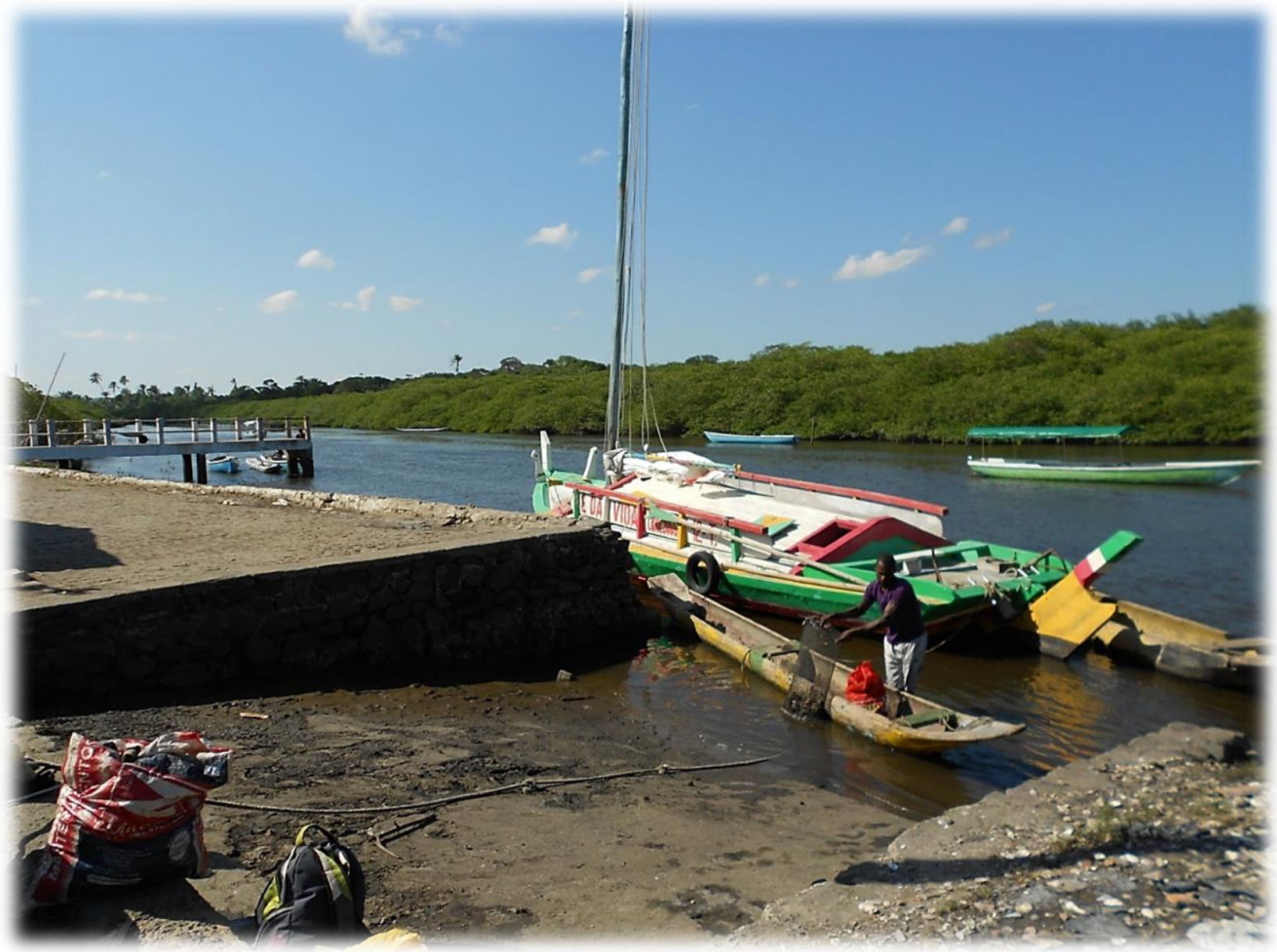

Cais 


\subsection{As olarias}

Maragogipinho tem cerca de 150 olarias (Moreira, 2010). As mais antigas situamse ao lado do rio Jaguaripe, no terreno de mangue, perto do cais. Elas foram erguidas sobre áreas aterradas, há muitos anos, com areia de praia, barro arenoso, cascalho e cinza dos fornos. No interior do vilarejo, há outras tantas olarias de fundo de quintal. Segundo a artesã Marijose, as olarias de fundo de quintal são em maior número, "geralmente, todo mundo aqui tem uma olaria no fundo do quintal".

O silêncio das peças prontas, dispostas para secagem, mistura-se com o rangido do torno, movido por pés descalços, e com ritmo pausado e violento dos amassadores - corpo todo jogado na cadência. Das mãos, brotam no barro novas figuras. Dependendo do dia, os grandes fornos de abóbada podem estar fechados, prenhes, quentes. Vozes e movimentos de crianças se misturam dentro e fora. De um lado, o mangue, o rio. De outro, a vila (Coimbra, 1980, p. 131). 


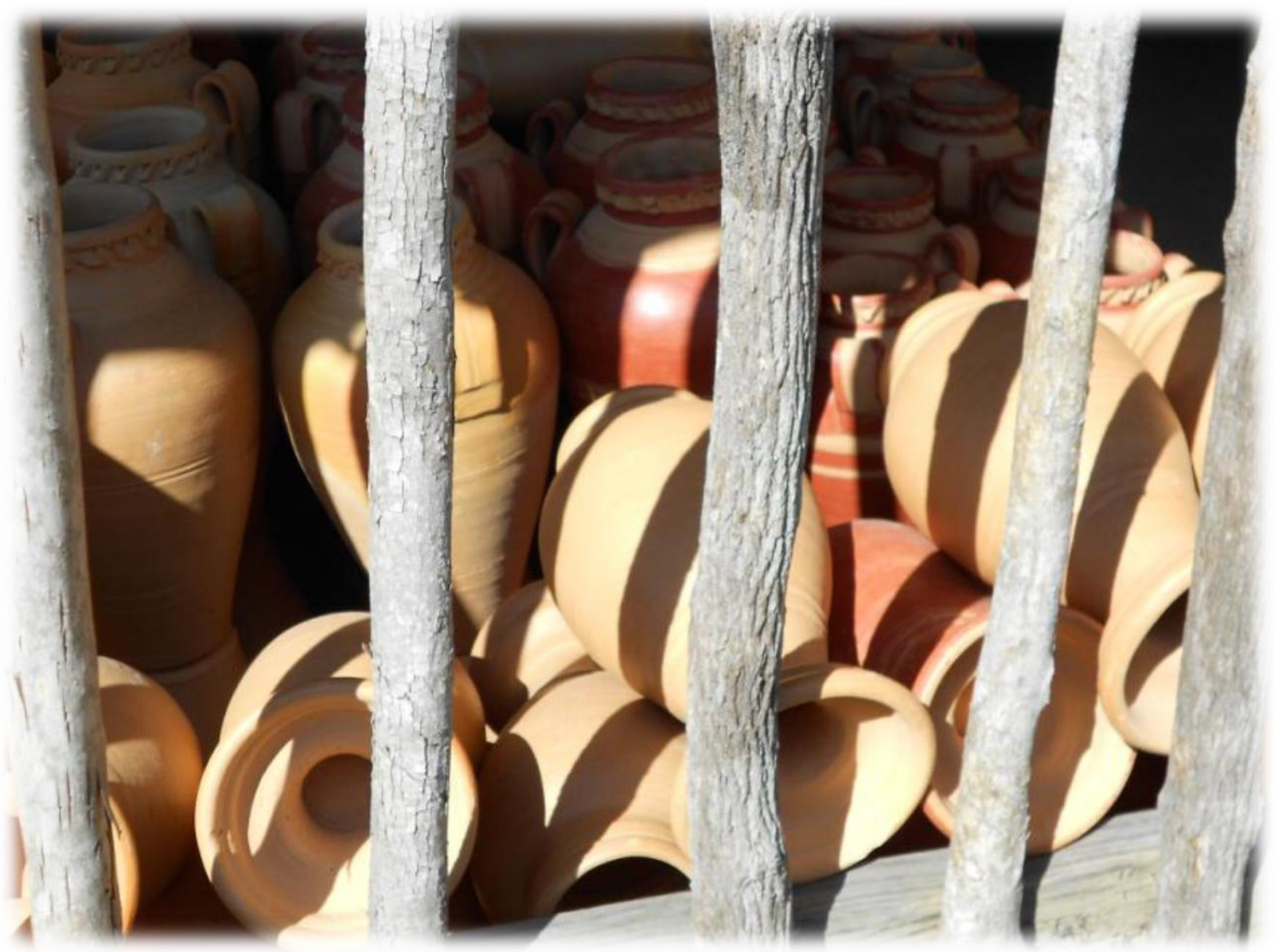

Vista externa de uma olaria 


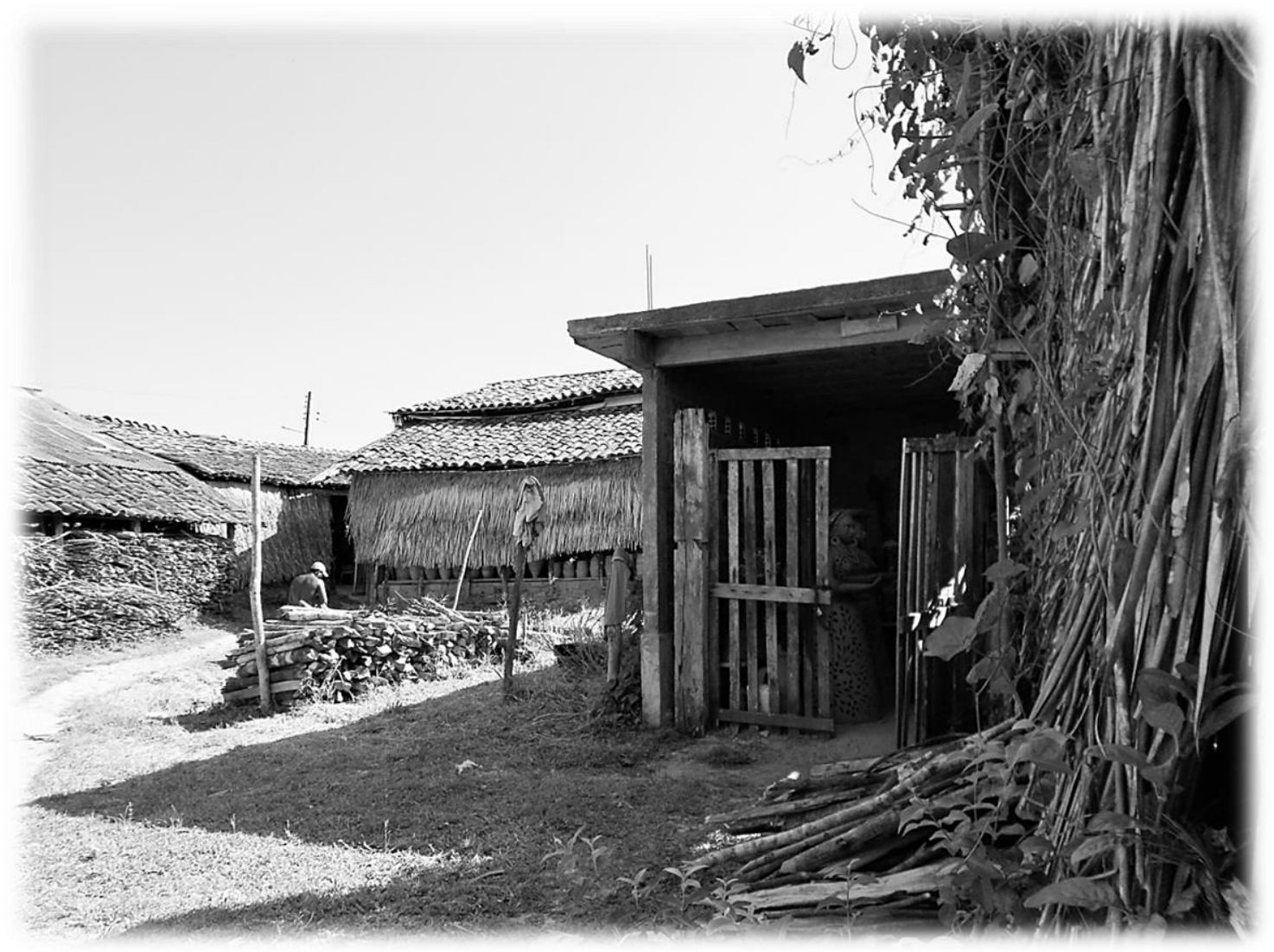

Caminho entre as olarias (antes do calçamento) 


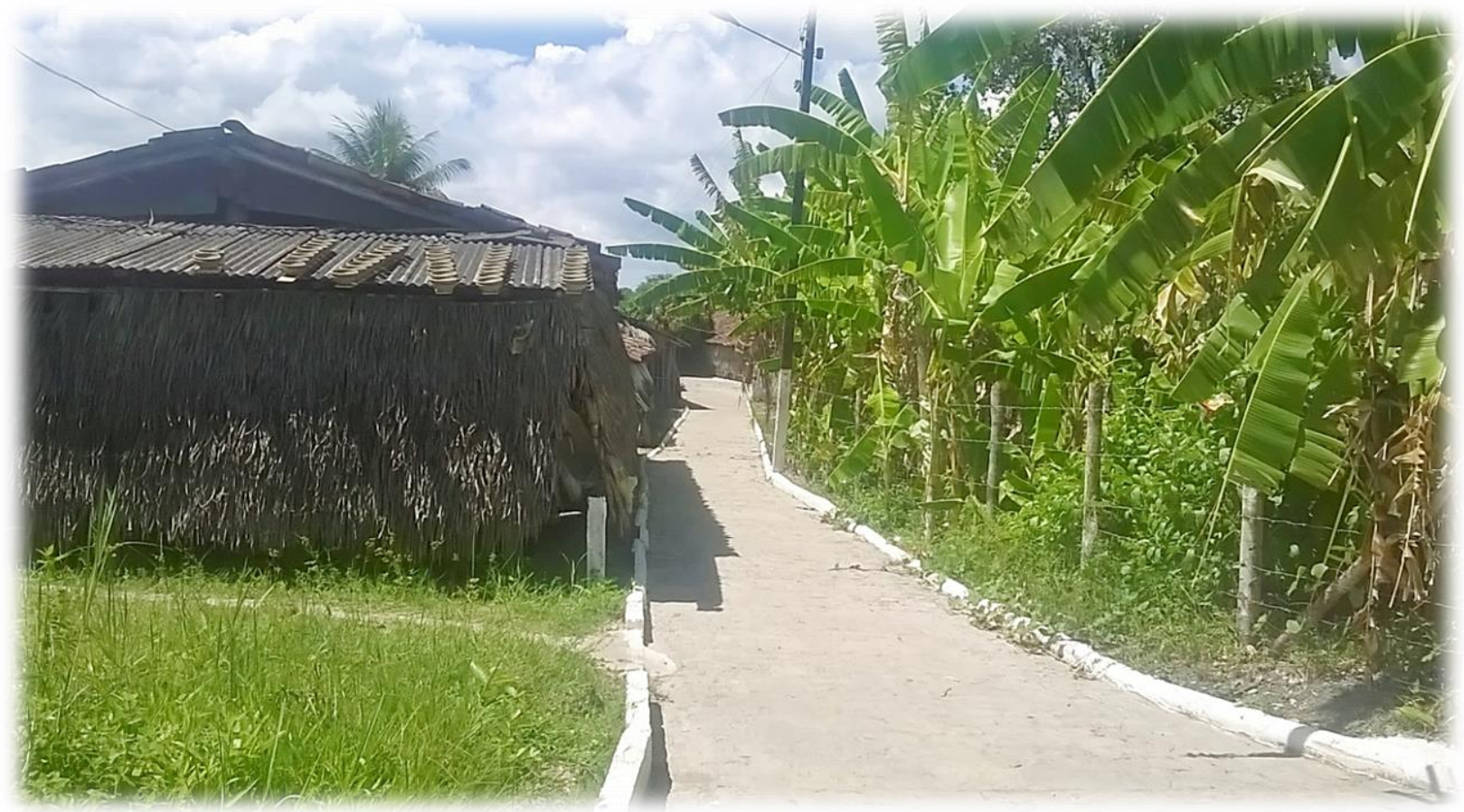

Caminho entre as olarias (depois do calçamento) 
As olarias são galpões construídos com materiais orgânicos, têm estruturas de madeira, paredes de palha de piaçava ou de troncos de madeira ladeados, chão de barro batido e, comumente, cobertura de telha cerâmica. Essa tradicional arquitetura facilita a circulação de ar e a iluminação natural no ambiente, fundamental para a secagem das peças de argila e para conforto ambiental dos artesãos produtores. Nas trilhas sinuosas por entre as olarias avistam-se peças secando ao sol e feixes de lenha empilhados, futuro fogo que lamberá as peças de barro.

Da última vez que visitei Maragogipinho, constatei que surgiram olarias feitas com tijolos e blocos. Essas novas construções afetaram significativamente a paisagem. Também percebi que várias das trilhas no interior da comunidade haviam sido calçadas com pedras.

Dentro das olarias, o torno ocupa um lugar de destaque, geralmente perto da porta, em local mais iluminado. Via de regra, os tornos são de madeira movidos pelos pés. Fato curioso é que, na memória oral da comunidade, está registrado que os portugueses trouxeram o torno para a região, que os índios não se adaptaram ao instrumento, e que os escravos africanos eram quem manejava o equipamento. 


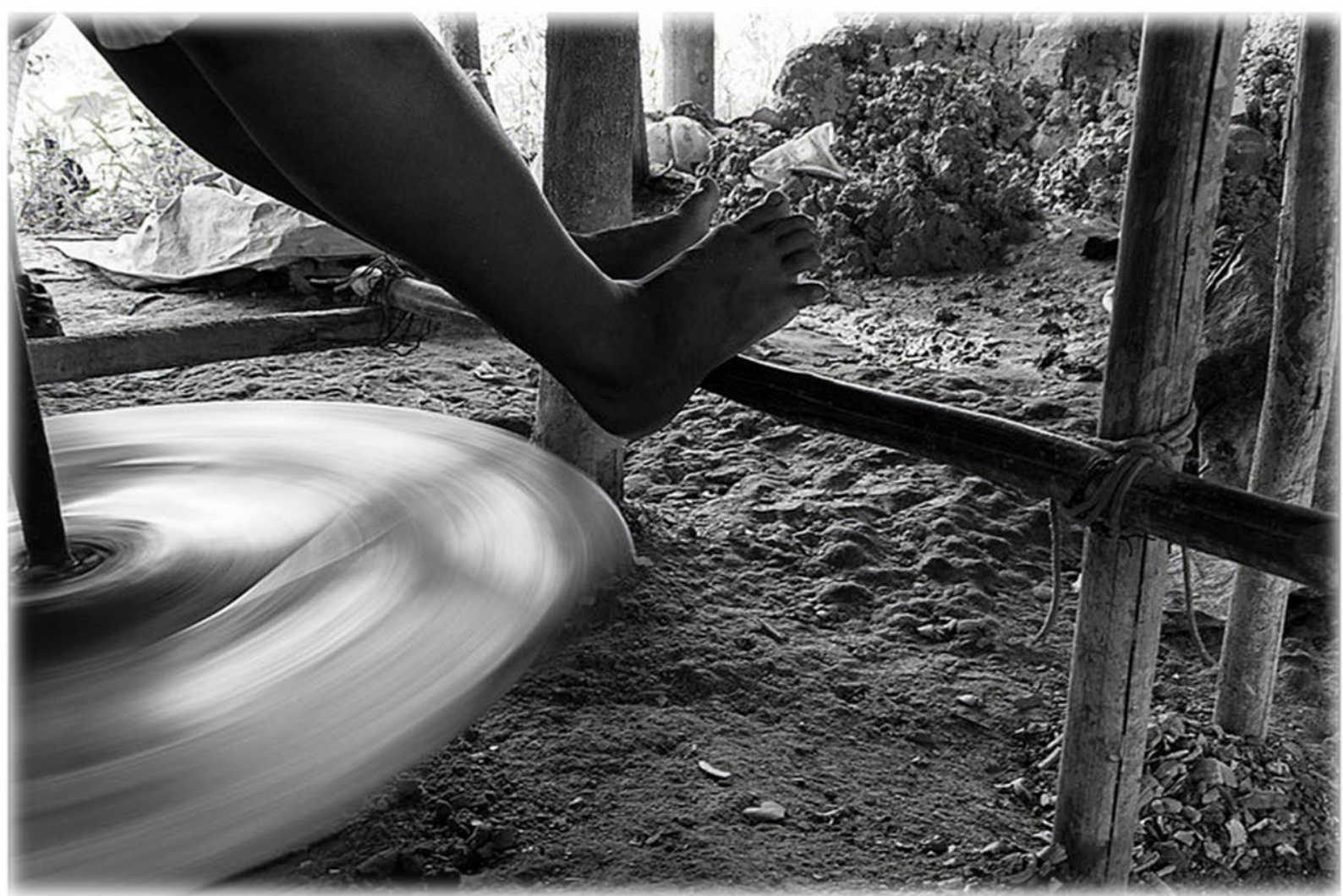

Movimento dos pés no torno de madeira

(https://farm1.staticflickr.com/312/18165907743_9c8f66b8f7_c.jpg) 
Foram os jesuítas que trouxeram o torno para cá. Como eles eram portugueses, o torno é português. Porque o que é que acontece: o nosso trabalho está entre as três raças: tem uma parte do índio, uma parte do negro e uma parte do português. (Oleiro Nelinho Mota).

No processo de colonização do Brasil, a representação social e a visão de mundo do indígena, do africano, do português e, na sequência, do mestiço, vão aparecer significativamente na produção simbólica no decorrer dos séculos seguintes. $\mathrm{Na}$ cerâmica de Maragogipinho, as formas e os temas pintados remetem explicitamente à mestiçagem do povo brasileiro.

O forno também ocupa um espaço de evidência na olaria. Há fornos de diversos tipos e tamanhos, mas predominam o "forno caieira", aberto em cima, e o "forno de capela", alto, abobadado, com a fornalha no plano inferior, separada da câmara de cozimento por uma grade revestida de tijolos. 


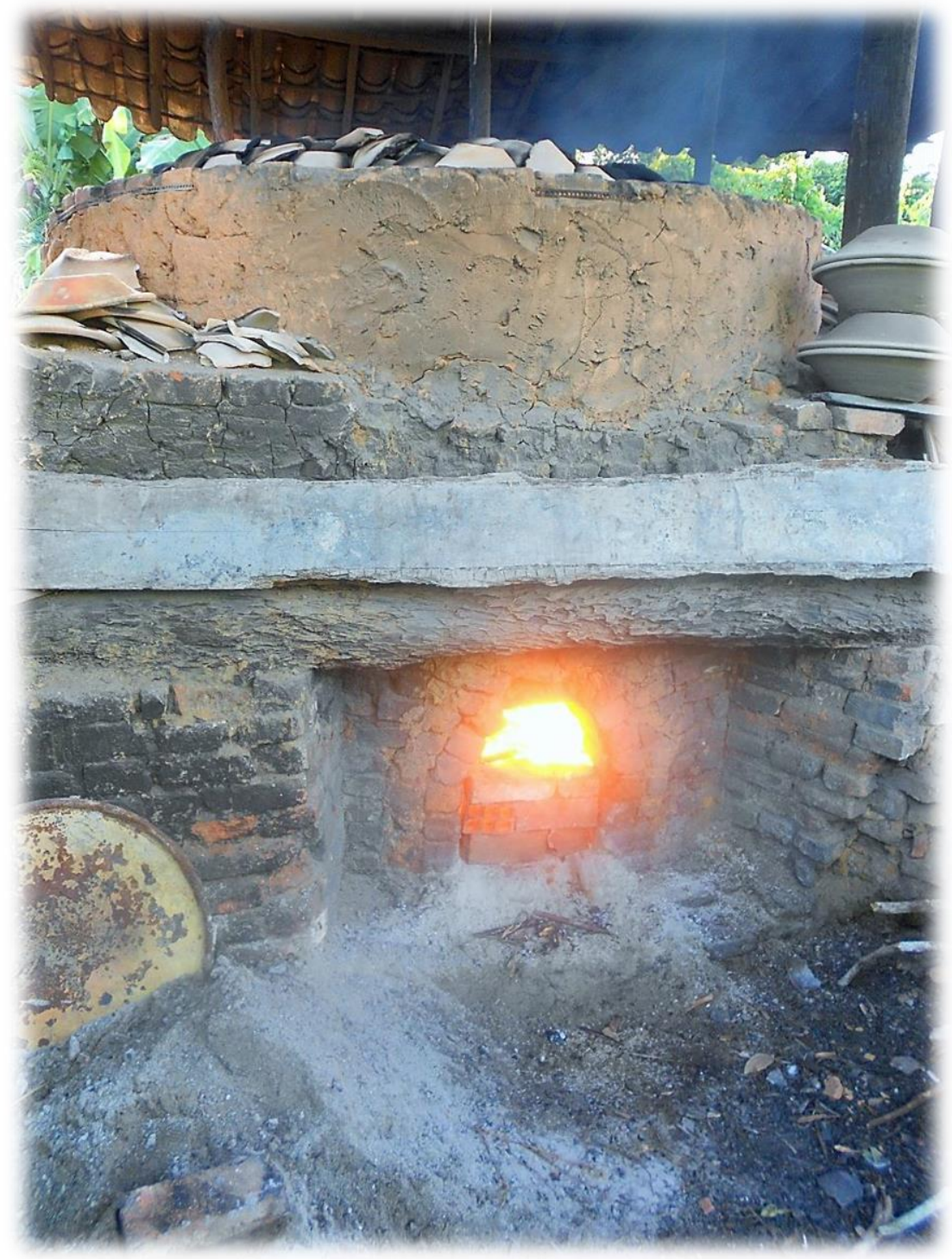

Forno caieira 


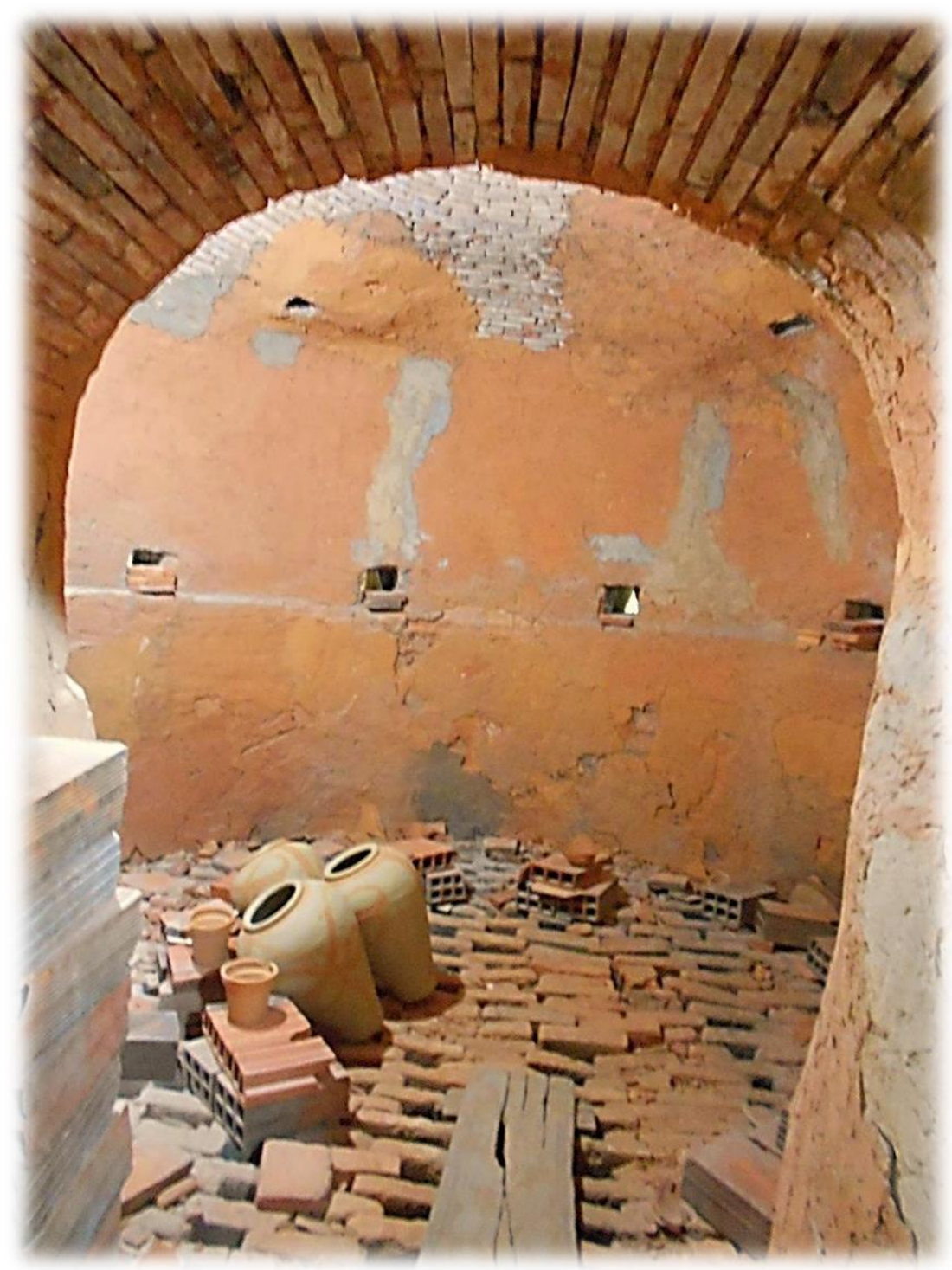

Forno de capela 
A organização do trabalho na olaria obedece a uma hierarquia originalmente familiar e que, nos últimos anos, se mantém em certa medida por meio do trabalho terceirizado. $\mathrm{O}$ oleiro, designado como "oficial", é o proprietário e a autoridade máxima, coordena os aprendizes e auxiliares e torneia as peças principais, ou todas as peças nas olarias pequenas.

Os trabalhadores recebem diferentes atribuições: o "barreirista" extrai o barro da jazida, o "amassador" é

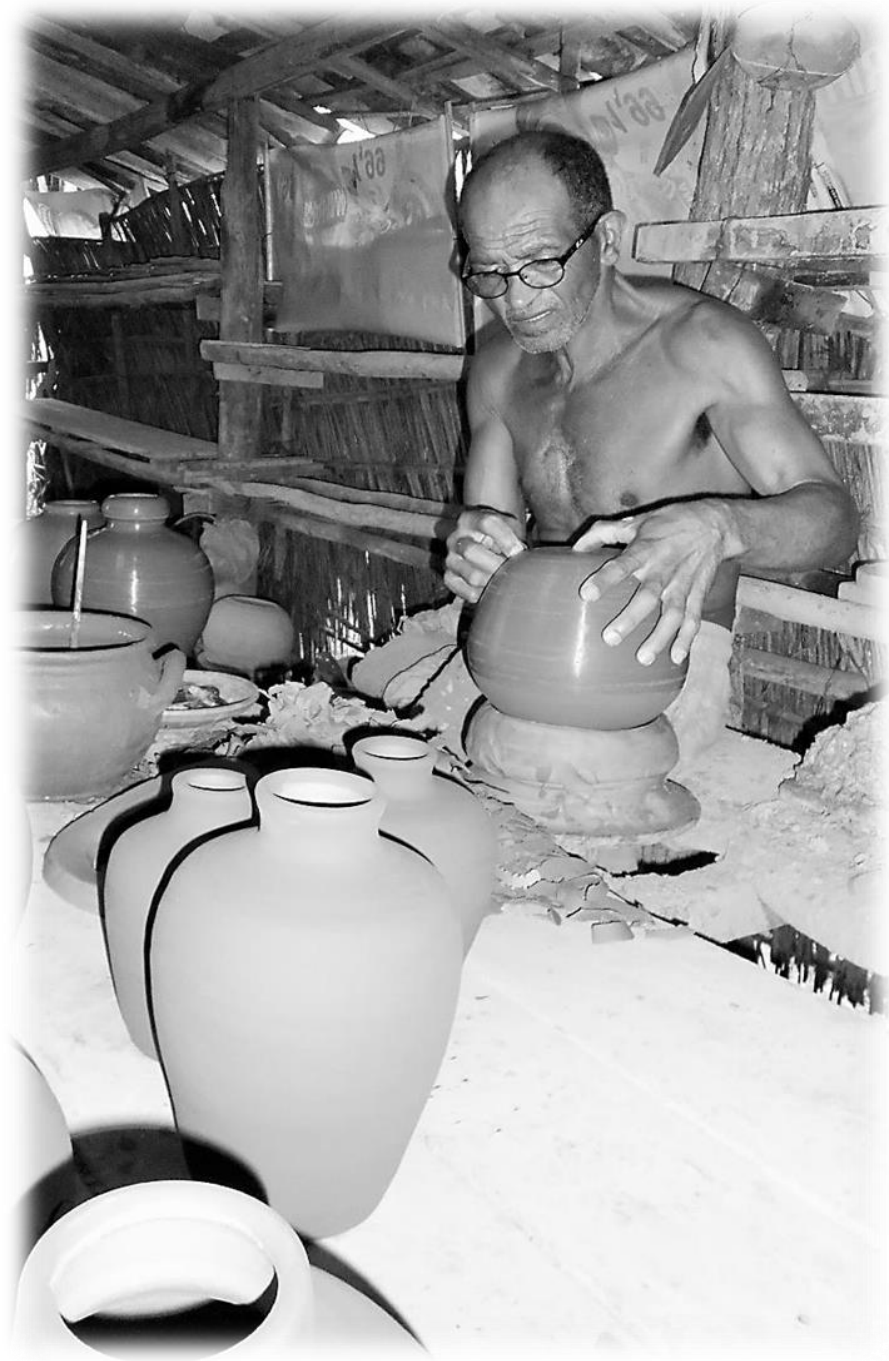

Oleiro: Seu Zé

quem pisa e amassa o 
barro, o "emendador" une as partes de uma mesma peça, o "queimador" alimenta o fogo e faz a queima das peças.

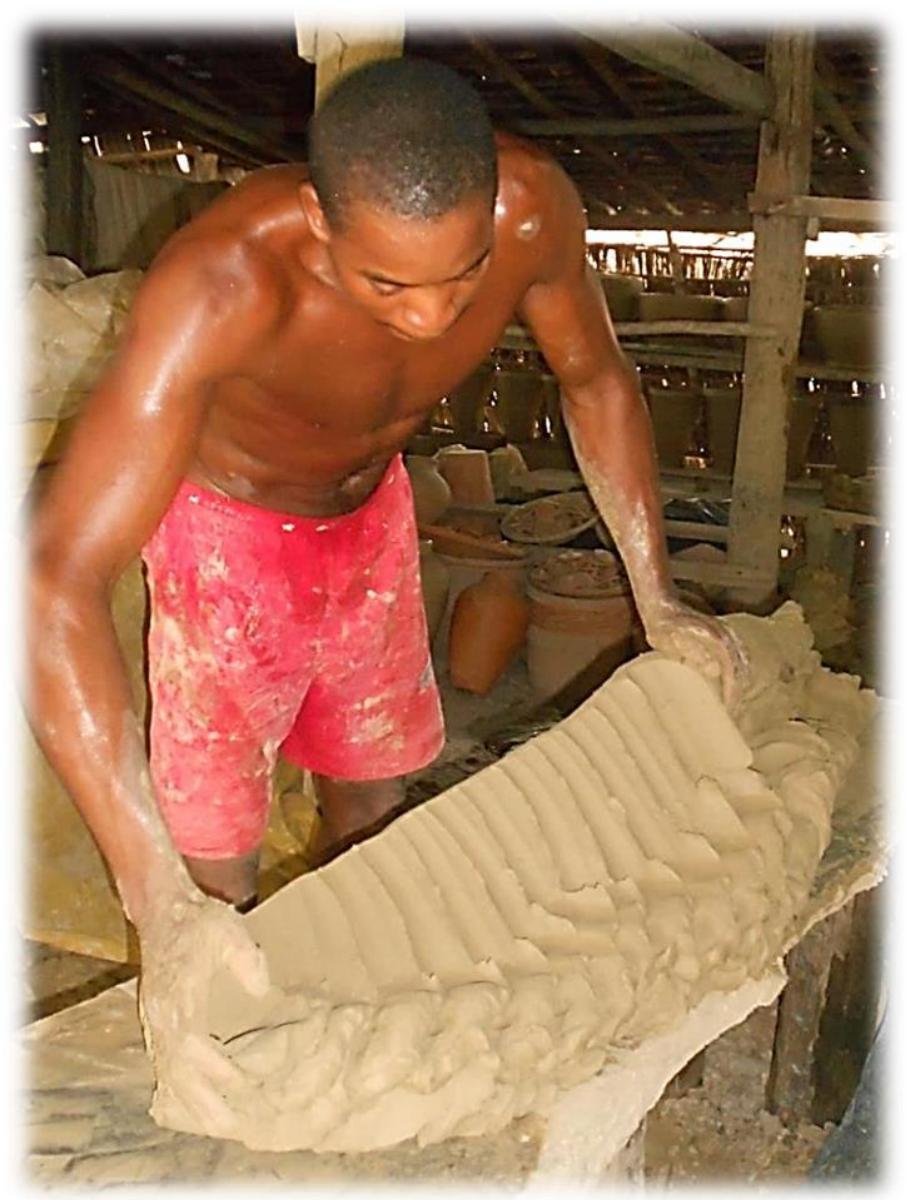

Amassador: Marinaldo Manuel de Jesus 
O trabalho das mulheres também recebe atribuições: as "brunideiras" ou "burnideiras" dão polimento às cerâmicas e as "pintoras" realizam a pintura. As olarias constituem a referência principal da vida dos habitantes de Maragogipinho, o centro das relações entre mulheres, homens e crianças.

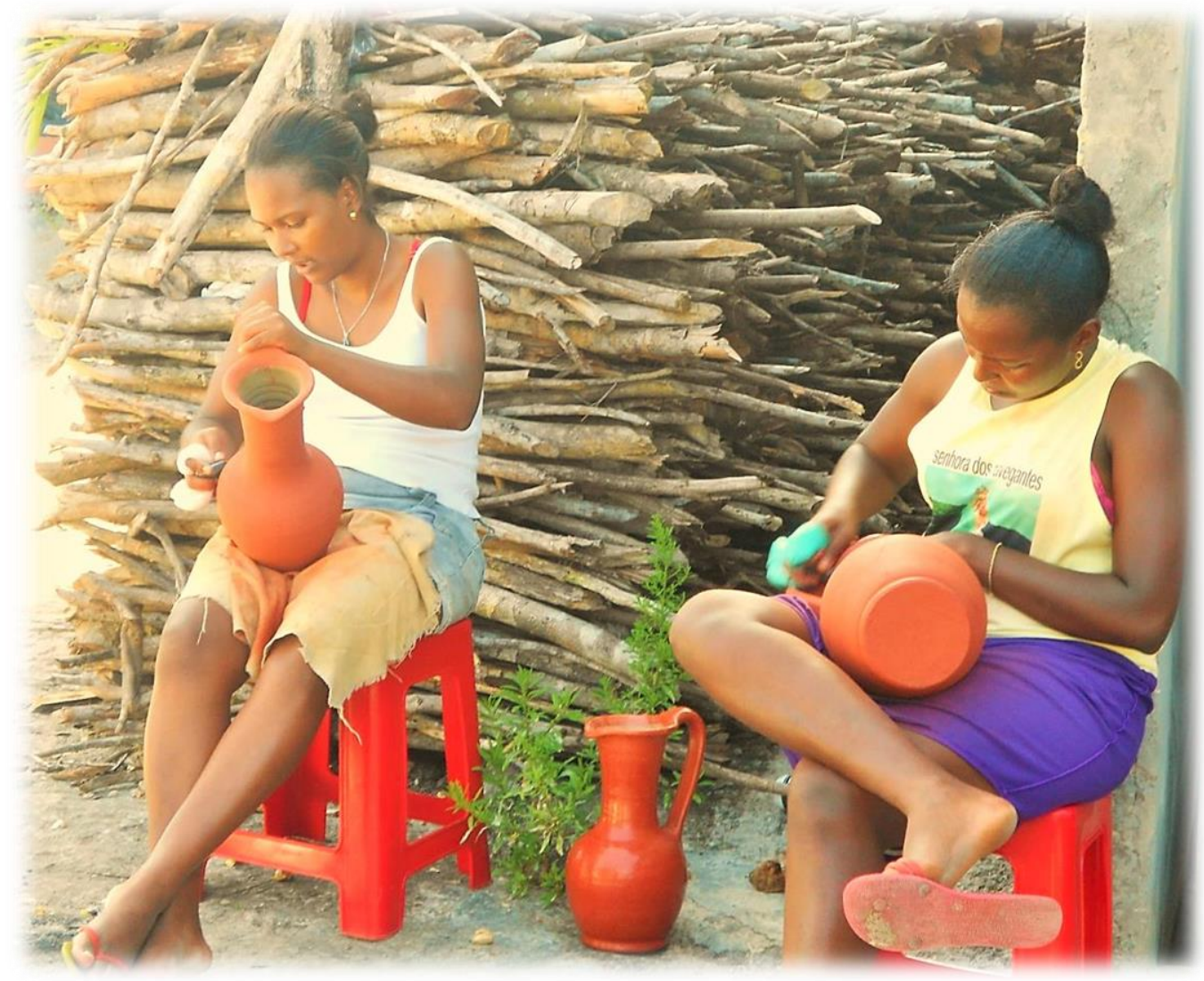

Brunideiras: Joseane Evangelista e Jussara Evangelista 
Em 1957, Pereira observou que toda a vila de Maragogipinho parecia uma vasta olaria. Em 2014, tive a mesma impressão:

Cai a tarde. Uma brisa fresca vinda do rio, bafeja Maragogipinho. As mulheres estão no fim dos afazeres a que se dedicaram o dia todo. Vão deixá-los dentro em breve a fim de preparar a janta para os filhos e maridos que vêm das olarias, mas chegamos a tempo de apreciá-las ainda. Umas, sentadas nas soleiras das portas, pintam moringas; outras, mesmo na rua, aos grupos, à sombra das casas, conversam enquanto vão executando o cansativo trabalho de brunir talhas, cacos ou moringas. Outras, ainda, recolhem peças que durante o dia estavam secando enfileiradas na calçada. E se continuarmos a percorrer as ruas e vielas de Maragogipinho, este nos há de ser um quadro constante. Olhando pelas janelas abertas, veremos no interior das casas - nas salas e nos quartos - potes, talhas, porrões, moringas e outros mais objetos de barro sobre as camas, sobre as mesas, sobre cadeiras e empilhados nos cantos. Voltando-se a fazer à noite a mesma ronda feita à tarde, será presenciado igual espetáculo, apenas variando o local da concentração - em vez da rua, o cenário é o ambiente doméstico, iluminado pelos fifós ou pelos lampiões a querosene (Pereira, 1957a, p. 56). 


\subsection{A AAMOM: Associação de Auxílio Mútuo dos Oleiros de Maragogipinho}

A Associação de Auxílio Mútuo dos Oleiros de Maragogipinho foi originalmente criada em 1956 e revitalizada a partir de 1998, com o objetivo de articular os artesãos e ajudá-los a intermediar negociações voltadas para a comercialização da cerâmica. A sede fica localizada na praça principal de Maragogipinho, dispõe de uma loja e um pequeno acervo de peças tradicionais. Apesar de não ter a adesão de todos os oleiros e de receber muitas críticas dos que dela não participam, a entidade procura aliançar parcerias importantes para a atividade de cerâmica. Por exemplo, conseguiu articulação com o Governo do Estado para a reforma da estrada de acesso à comunidade.

A AAMOM se propõe a exercer um papel atuante na vida de Maragogipinho. A intermediação de vendas de peças para grandes empresas, como a Tok Stok e a oferta de cursos de técnicas tradicionais, como a pintura em tabatinga, são atividades promovidas recentemente pela Associação, que busca incentivar uma participação mais efetiva dos associados. 
Marijose Pinto dos Santos tem 37 anos e é a atual presidente da AAMOM, está em seu segundo mandato. Contou-me que não queria o cargo, mas que os oleiros insistiram muito com ela, a sua votação obteve unanimidade.

Percebi que Marijose mantém um envolvimento visceral com o trabalho que

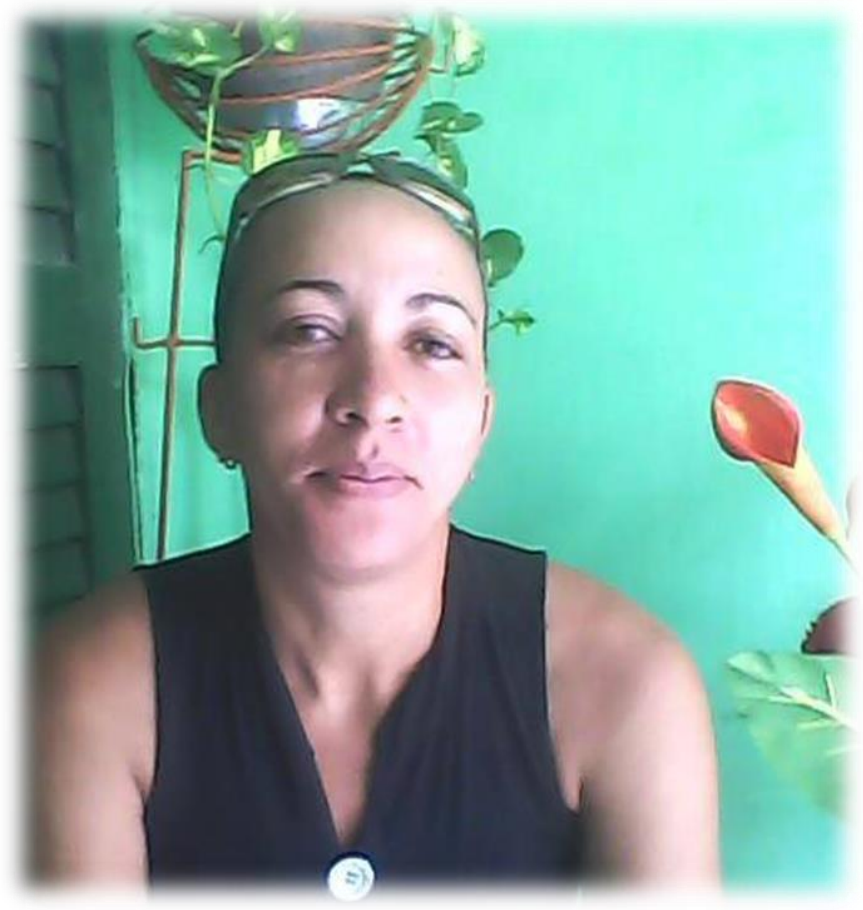

Marijose, presidente da AAMOM desempenha na associação. Assim como os outros artesãos e artesãs com quem conversei, ela emana uma delicadeza própria de quem coexiste com o barro.

Marijose é filha de uma costureira e de um eletricista, como ela mesma afirmou: "não vim da linhagem do barro, mas comecei a trabalhar com ele aos quinze anos". Ela possui uma olaria própria, sabe tornear, mas seu trabalho pessoal é com escultura. Mostrou-me algumas peças de sua autoria: pequenas esculturas de corpos humanos em movimento com formas 
estilizadas, sem detalhes, simples e bonitas. Na olaria, além das esculturas, também executa o acabamento no torno das peças realizadas por oleiros contratados, assim como as queimas: trabalhos marcadamente masculinos:

Um trabalho aqui que era só de homem era o de queimar o forno. Eu queimo o forno. Dá para contar as mulheres que fazem isso aqui, são pouquíssimas, pouquíssimas. Até porque é um trabalho pesado, muito pesado, mas as minhas peças sou eu que queimo.

Na Associação, há poucas mulheres. Marijose é representante de uma maioria masculina. Perguntei-lhe como ocorre a relação entre os homens e ela, se eles a respeitam, se alguns são machistas:

Não, não são machistas. A mulher e o homem hoje dividem o espaço. (...). A diretoria só tem três mulheres: eu e mais duas, o restante é tudo homem. Na verdade é até surpreendente, mas partiu deles mesmos quererem uma mulher [para presidente]. Eu não sou a primeira, eu sou a segunda. Mas a primeira não era artesã, era professora. Eu olho por esse lado: por eu ser de fato uma artesã. 
O cargo que Marijose ocupa não é fácil, mas percebi que tem clareza e consciência da complexidade que envolve articular três dimensões fundamentais no artesanato da cerâmica: a conservação das tradições, a incorporação de novas tecnologias e o sustento econômico dos artesãos.

Em janeiro de 2015, na segunda vez em que visitei Maragogipinho, encontrei Marijose muito ocupada com a reativação de uma usina de processamento de barro para a comunidade. Essa usina tinha sido montada há mais de 14 anos, mas nunca havia entrado em funcionamento porque faltaram verbas para a sua implantação. Nesse momento, a AAMOM tinha conseguido a liberação de um dinheiro para revitalizar a usina, reformar a estrutura do galpão, lubrificar o maquinário parado e obter o treinamento técnico sobre o uso das máquinas pela empresa que as comercializou.

Alguns oleiros haviam me contado sobre essa empreitada. O processamento do barro pelas máquinas dispensaria, muitas vezes, o trabalho do amassador, figura já escassa no mercado. Além do mais, a usina contribuiria muito com a manutenção da qualidade das peças, pois o barro teria condições de maior pureza. A usina possui também um forno elétrico de alta temperatura. Apesar de a cerâmica em alta temperatura não ser praticada na comunidade, novas 
possibilidades de trabalho se abrem com esse forno. Marijose se declarou bastante otimista com a revitalização da usina e da loja.

\subsection{Raízes de Maragogipinho}

Maragogipinho é um distrito do município de Aratuípe, antigo aldeamento de Santo Antônio, organizado no século XVI para catequese dos índios. Atualmente, é considerado pela UNESCO como um dos maiores centros de produção artesanal de cerâmica da América Latina. O povoado não é muito distante de Salvador: 225 km pela BR 101, ou 71 km atravessando de ferry boat pela ilha de Itaparica.

Maragogipinho localiza-se próximo à Nazaré das Farinhas, cidade com a qual se comunica intensamente por via fluvial ou terrestre. Nos arredores, o cultivo da mandioca é abundante para a fabricação de farinha e seus derivados. A povoação iniciou-se à beira de um braço do rio Jaguaripe, o "rio Maragogipinho", que conserva aspecto nativo, onde correm pequenos e serpenteantes cursos d'água, beirados pelo mangue e pela mata. O lugar preserva características tipicamente rurais. Arruados irregulares, alguns já com calçamento, convergem para o largo da Igreja Matriz Nossa Senhora da Conceição, construída no ponto mais alto do 
terreno no ano de 1710 e reformada em 1930. A maioria dos seus 3000 habitantes, segundo dados de 2010, vive do trabalho com o barro.

As vozes das crianças se fazem escutar junto com o insistente canto dos galos e o latido dos cachorros. Por onde se anda, veem-se vestígios da atividade cerâmica. Nas praças, em frente das olarias e das casas, mulheres dão polimento e realizam a pintura de peças de barro, antigos hábitos que ainda perduram no século XXI.

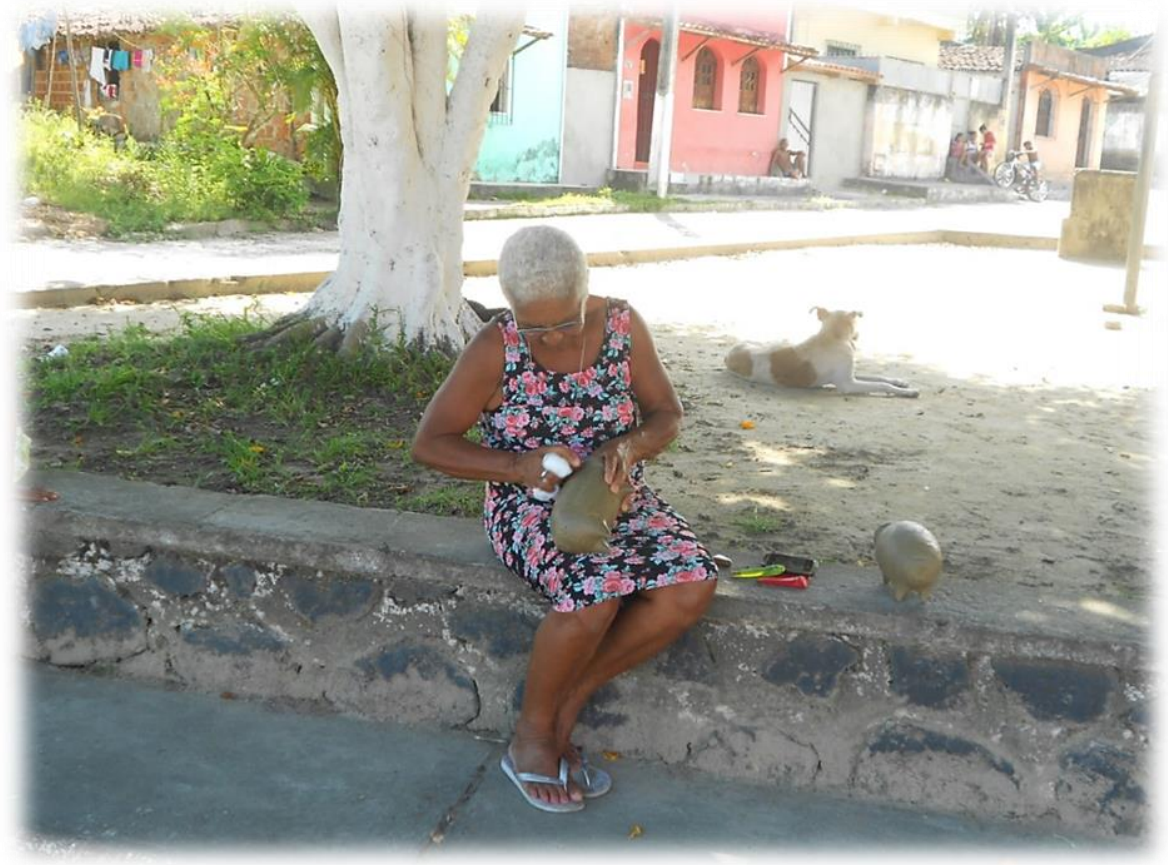

Janete dos Santos brunindo um porquinho de barro 


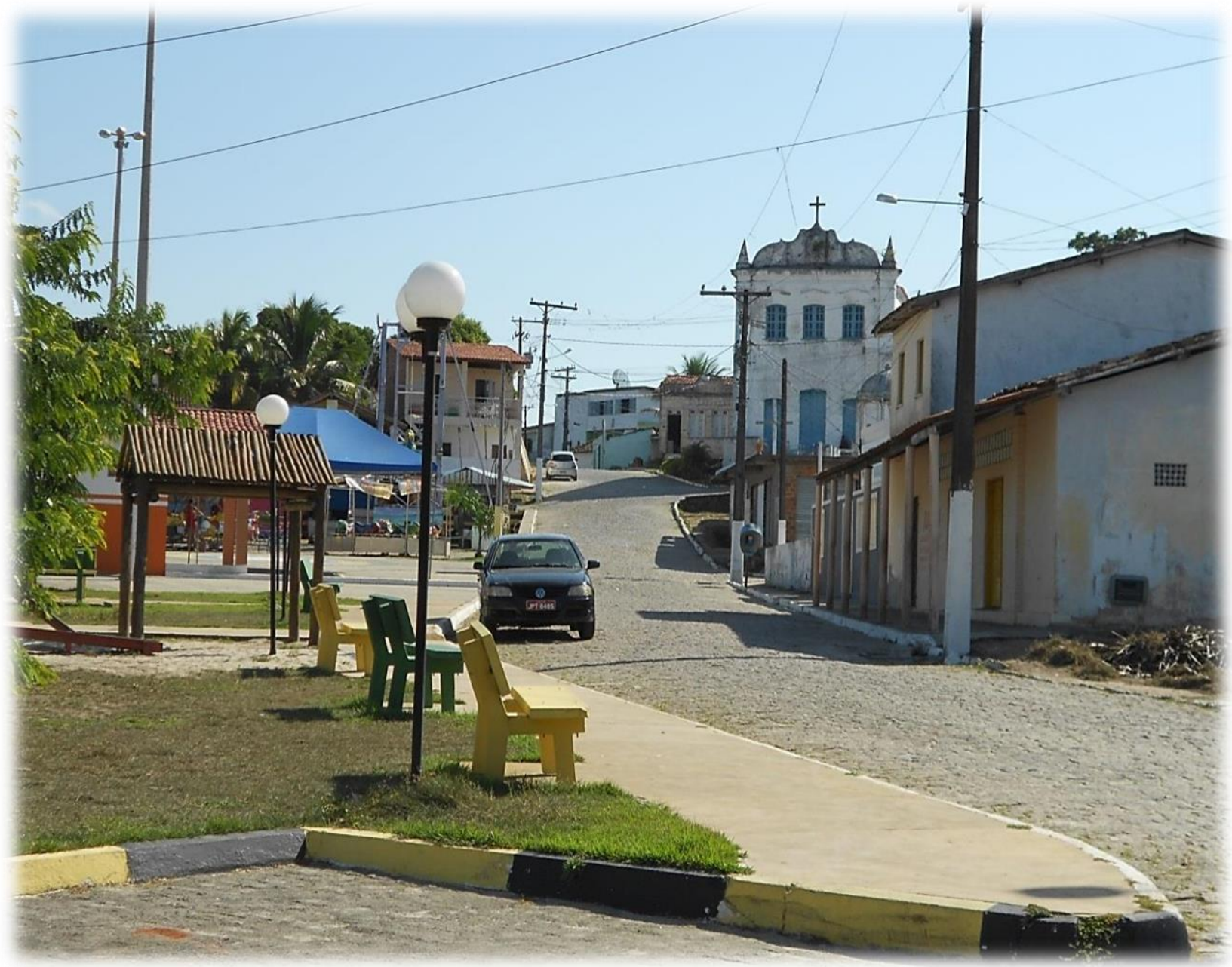

A igreja Matriz vista do cais 
Segundo o oleiro Nelinho Mota, a atividade cerâmica começou no século XVIII inicialmente em Jaguaripe, pequena cidade próxima, fundada pelos jesuítas, à beira do rio Jaguaripe:

Dizem... Não tem uma historia real aqui, mas dizem que a origem da cerâmica vem dos jesuítas. Quando os jesuítas vieram para cá, já existiam os índios. Aqui era um lugar que tinha índios, tanto que há um lugarejo aqui em cima que se chama Santo Antônio dos Índios, lá tem uma igreja bem antiga, só em ruínas. Dizem que este trabalho não era diretamente daqui, não nasceu aqui, foi mais abaixo, em Jaguaripe, é uma cidadezinha histórica. Dizem que o trabalho com barro começou lá e terminou vindo para aqui.

Em crônicas do século XVIII, se encontram depoimentos sobre a importância da atividade oleira em Maragogipinho. Todas as evidências levam a acreditar que algumas das povoações existentes no Vale do Rio Jaguaripe são bem antigas, eram aldeias onde populações indígenas uniram-se a remanescentes de quilombos, na busca de condições favoráveis para a sobrevivência. Os índios já produziam a cerâmica na sua atividade cotidiana (Coimbra, 1980, p. 131). 
Pereira (1957a, p. 12) afirma que os colonizadores, ao fundarem as primeiras olarias no Brasil, nada de novo trouxeram para a terra. A tradição de trabalho no barro já se encontrava firmada entre os indígenas muito antes de os portugueses aqui chegarem. Quando os jesuítas, movidos pela necessidade de provimento de louças, tijolos e telhas, começaram a instalar olarias junto aos colégios, empregaram, em larga escala, a mão de obra indígena, trabalhadores já familiarizados com as artes do barro e capazes de oferecer muito de si nesse ofício.

Nos engenhos de açúcar, a olaria também exercia uma função respeitável. André Antonil, em escritos de 1711, comenta essa importância:

Ter olaria no engenho, uns dizem, que escusa maiores gastos, porque sempre no engenho há necessidade de fôrmas, tijolo e telha. Porém, outros entendem o contrário, porque a fornalha da olaria gasta muita lenha de armar, e muita de caldear, e a de caldear há de ser de mangues, os quais tirados são a destruição do marisco, que é o remédio dos negros. (...) Tendo, porém, o senhor de engenho muita gente, lenha e mangues para mariscar de sobejo, poderá também ter olaria, e servirá esta oficina para grandeza, utilidade e comodidade do engenho (Antonil, 1997, p. 131). 
No caso de Maragogipinho, juntaram-se à população local os descendentes dos imigrantes da península ibérica, ceramistas que possuíam indústria de louças e tijolos na vizinha cidade de Jaguaripe e entraram em decadência por conta de, entre outros fatores, problemas com o fisco. Foi em Maragogipinho que se confeccionou a louça artística e utilitária que a população da monocultura açucareira consumia.

Desse modo, a atividade oleira em Maragogipinho é bastante antiga e arraigada. Em 1888, Durval Vieira de Aguiar elogia a produção artística da comunidade e a descreve com uma nuança de prosperidade:

Descendo-se o rio, desde Nazaré, encontra-se à direita o canal que conduz ao Rio d'Aldeia, e antes, a industriosa povoação de Maragogipinho, cheia de olarias, onde se fabricam as melhores vasinhas de barro de nosso mercado, como sejam: potes, talhas, bilhas, moringas, quartinhas, copos, panelas, caborés, etc., etc., especialmente as talhas de encomenda, pintadas e esculpidas, que são verdadeiros primores de arte. Escusa dizer que esse vasilhame, não vidrado, nos faculta as melhores resfriadeiras naturais até hoje conhecidas (Aguiar, apud Pereira, 1957a, p. 58). 
A influência portuguesa na cerâmica faz-se notar já em fins do século XVII e início do XVIII, na introdução do torno ou a roda de oleiro, bem como do forno coberto, queimado à lenha, processos no tratamento do barro que se Tabatinga em pó estabeleceram e permanecem até os dias de hoje em Maragogipinho.

A pintura com tauá, argila fina de coloração avermelhada, e o grafismo das peças com tabatinga, argila branca, em que predominam motivos da natureza, remetem a culturas indígenas e representam a marca de distinção da cerâmica de Maragogipinho.

A água encanada, assim como outros avanços industriais e tecnológicos causaram profundas transformações à produção de arte cerâmica em Maragogipinho. Hoje em

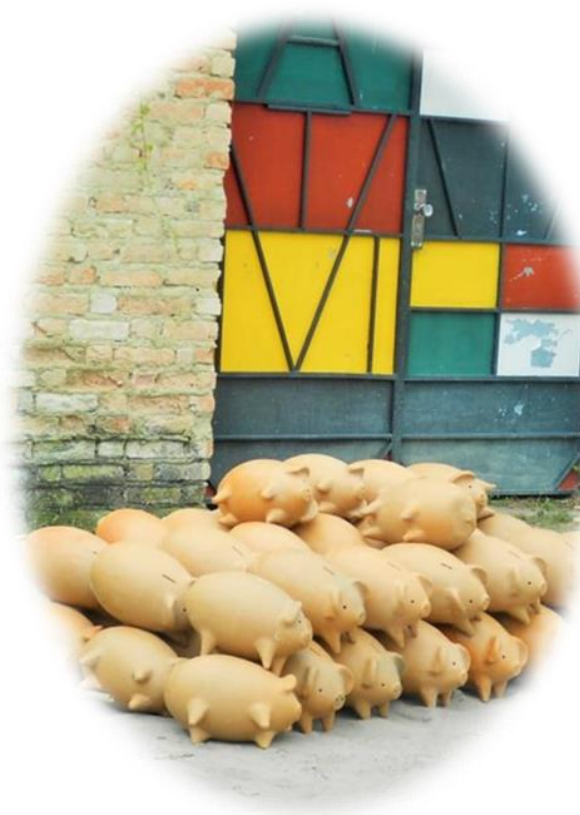

Porcos de barro à espera de transporte 
dia, a técnica de pintura predominante é a realizada a frio, com tinta acrílica colorida. Além das peças utilitárias e religiosas, há representações de animais como o porco, que é fartamente produzido, em múltiplos tamanhos e cores.

O porco-cofre, o boi-bilha (bilha em forma de boi) e a baiana (moringa em forma de mulher) tornaram-se objetos emblemáticos da cerâmica de Maragogipinho.

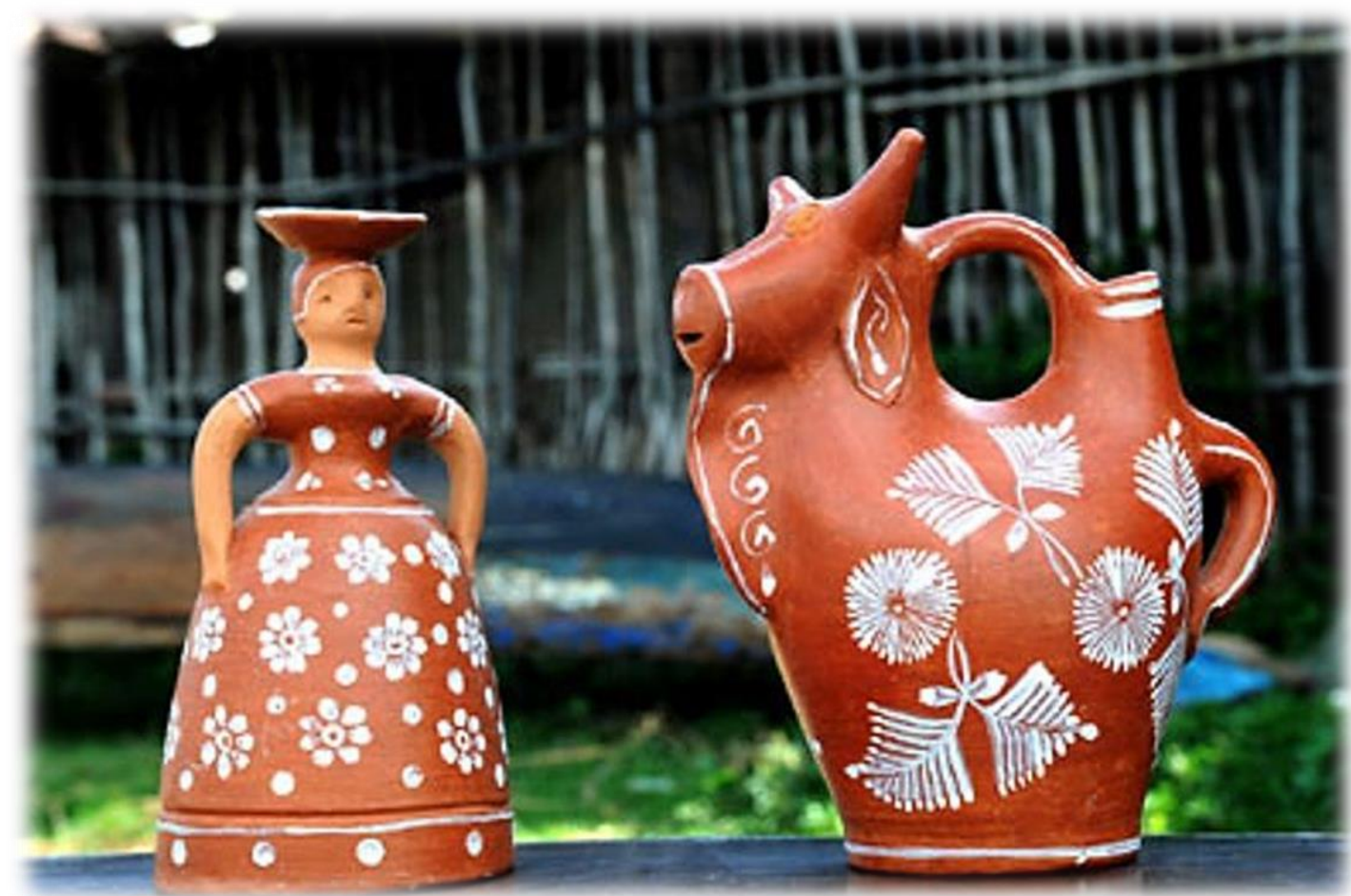


106 
Cipriano Algor só se lembrou das duas ameaças, a certa e a latente, quando varria o forno, é o que têm de bom as associações de ideias, umas vão puxando pelas outras, de carreirinha, a habilidade está em não deixar perder o fio da meada, em compreender que um caco no chão não é apenas o seu presente de caco no chão, é também o seu passado de quando o não era, é também o seu futuro de não saber o que virá a ser.

Saramago, 2000, p. 182 


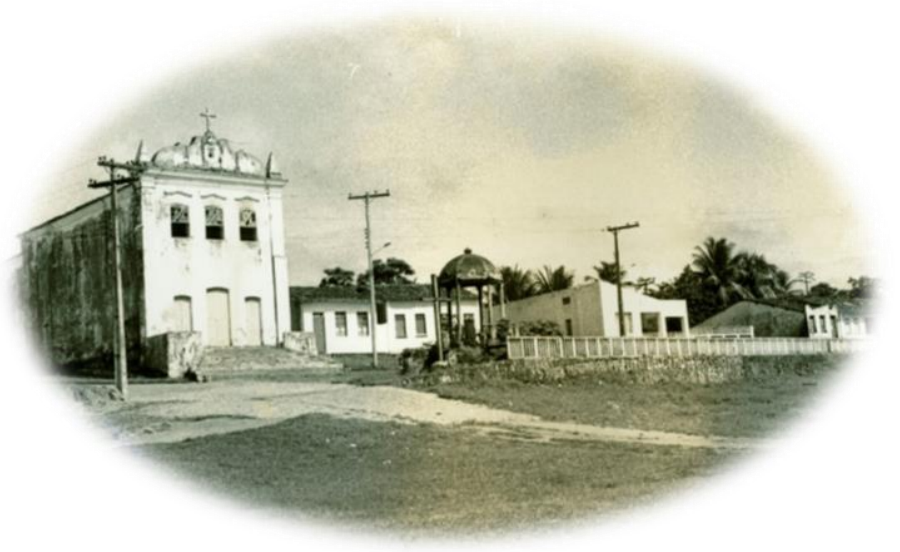

Maragogipinho em meados de 1970

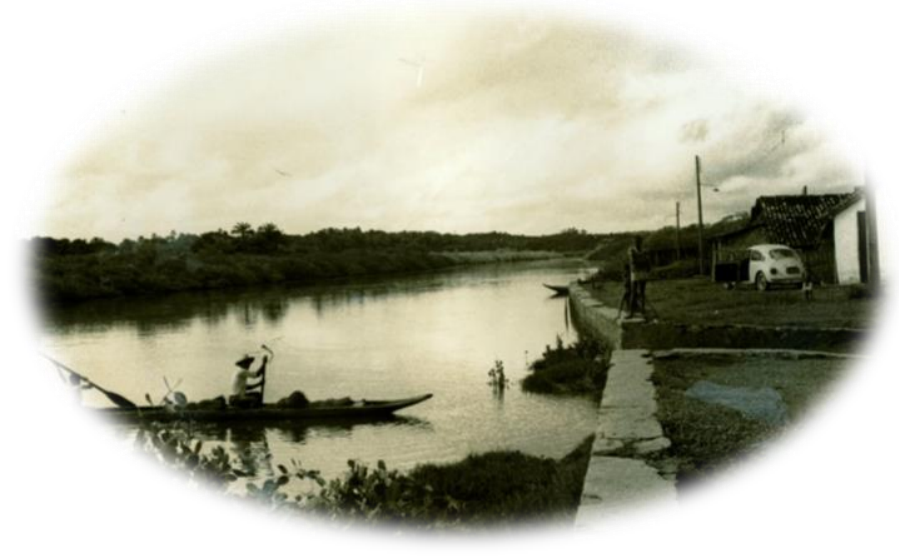

Fotos (http://maisbahia.blogspot.com.br/search/label/Maragogipinho) 


\section{Clamores do tempo: história dos ofícios}

\section{artesanais}

\subsection{O período medieval}

O artesanato é o meio mais antigo de se fazer objetos e, durante milênios, foi o único modo. A humanidade se constituiu por meio de artefatos feitos à mão até surgir, recentemente, a máquina. Para compreendermos melhor a formação histórica e a organização econômica desses ofícios, nos reportaremos a épocas em que a sociedade, dividida em grupos autossuficientes, produzia bens para suprir necessidades de sobrevivência. Cada um desses grupos constituía uma família, em seu sentido mais amplo, com escravos agregados e, mais tarde, os servos. Pereira (1957b, p. 22) cita o Engenho de Açúcar do Brasil colonial como um típico feudo, uma autêntica sociedade fechada autossuficiente.

A noção de divisão do trabalho aparece em determinado momento histórico, quando um dos membros do grupo social se especializa em um ou mais ofícios e vira um artesão. Os povos ibéricos trouxeram consigo o termo artesão e deles herdamos os modos de organização do trabalho artístico provenientes das antigas 
corporações de ofício. As corporações de ofício, ou guildas, eram instituições típicas da sociedade medieval, reuniam profissionais do mesmo ramo em associações. Na Europa do século XIV, especialmente nas regiões que deram origem à França, Espanha e Itália, a formação das cidades e o uso do dinheiro possibilitaram aos artesãos viver exclusivamente de sua profissão para atender ao mercado emergente. Padeiros, carpinteiros, ferreiros, tecelões produziam e vendiam seus produtos em oficinas especializadas, onde trabalhavam lado a lado mestres e aprendizes.

Durante muito tempo, essas corporações tiveram por princípio a igualdade entre os trabalhadores. Nas oficinas, havia uma divisão hierárquica do trabalho que iniciava com o aprendiz, passava pelo jornaleiro e chegava até o mestre. É relevante afirmar que a ascensão de uma condição à outra era regra e não exceção.

O dono da oficina era o mestre-artesão. Ele articulava os contatos comerciais necessários para vender a produção, era proprietário das ferramentas, conseguia a matéria-prima e recebia a maior parte dos lucros obtidos com a venda das peças finalizadas. Vários mestres ocupavam o seu tempo participando também do processo de fabricação. 
Logo abaixo do mestre-artesão vinham os oficiais jornaleiros, que executavam grande parte das tarefas ligadas ao processo produtivo. Em troca de seu serviço, ganhavam um salário estipulado pelo mestre, que variava muito, pois dependia do desempenho comercial apresentado pela oficina.

Na última escala da hierarquia de uma oficina, ficavam os aprendizes, jovens que moravam, aprendiam e trabalhavam com o mestre principal, em troca de um pequeno soldo (em alimento ou em dinheiro). 0 tempo de aprendizado durava de acordo com o ramo e possibilitava ao iniciante o conhecimento dos segredos do ofício. Quando concluía o curso, o aprendiz tinha de ser aprovado em um exame para poder abrir a sua própria oficina ou continuar a trabalhar com o seu ou com um novo mestre, recebendo um salário.

Entre os séculos XIII e XIV, na Europa, as corporações se preocupavam com o bem estar de seus membros, prestavam ajuda a quem se encontrasse em dificuldades. Predominava mais um espírito de fraternidade e menos de concorrência entre os trabalhadores. A regra de que todos os associados passassem pela etapa do aprendizado assegurava o conhecimento do ofício e a qualidade do trabalho. A 
corporação se orgulhava de seu nome e garantia ao comprador um padrão mínimo dos produtos que oferecia (Huberman, 1974, p. 65).

Com o desenvolvimento do comércio e das cidades, o sistema corporativo sofreu transformações radicais procedentes da crescente desigualdade social e econômica entre os trabalhadores. Ao contrário da economia medieval, que mantinha a pessoa ligada ao grupo pela reciprocidade de serviços, na sociedade do capitalismo insurgente o poder do dinheiro incitava o espírito individualista, estimulava a emancipação pessoal, substituindo o espírito corporativo medieval por relações de mando.

Hauser (1969, p. 331) comenta que a antiga igualdade entre os artesãos organizados em corporações cede lugar à diferenciação graduada pelo poder político e econômico. Os mestres de ofício passam a ser desvalorizados: sua posição social submerge à medida que o sistema econômico os desapossa da autoridade no conhecimento do trabalho, muitos começam a impedir a ascensão de companheiros ao nível de mestre. Os oficiais descem à categoria de assalariados permanentes e, deste modo, vai se formando, desde o século XIV, uma classe operária impedida de elevação socioeconômica. 
Daí por diante assistiremos a gradativa decadência do 'mestre', quando por força da revolução econômica para a qual ele próprio contribuiu, os mercados se alargam de urbanos para nacionais, em face da criação dos Estados modernos. (...) [o artesão] é forçado a sujeitar-se ao 'intermediário' que, por sua vez, irá roubar-lhe a projeção no cenário econômico, embora inicialmente não produza e apenas negocie (Pereira, 1957b, p. 23).

Os artesãos medievais perdem sua autonomia, pois começam a depender de um empreendedor para obter a matéria-prima e os instrumentos de seu trabalho.

Firma-se uma tendência para o artífice perder o contato com o público, assumindo o intermediário o papel de consumidor exclusivo e aos poucos anulando a independência do artesão que vem a trabalhar com a matéria-prima por ele fornecida e, muitas vezes, chega ao ponto de alugar os utensílios de trabalho. Nada mais tendo que seja propriamente seu, o artífice, até então, autônomo, adquire a condição de empregado e o comerciante passa a ser o empresário de seus serviços, praticamente assalariando-o. Nasce a 'empresa' (Idem, ibidem).

As corporações tiveram a sua fase áurea no século XIII, começaram a decadência no século XIV para entrarem em declínio franco a partir do século XVI. 


\subsection{Artesanato e arte na Renascença}

A habilidade manual vai perdendo seu valor à medida que cresce o fascínio pelo uso da máquina. Na nova sociedade europeia, emerge com vigor a divisão entre artes liberais e artes mecânicas. As artes liberais eram as artes que exigiam esforço mental: a gramática, a retórica, a lógica (a arte de pensar), a aritmética (a arte de calcular), a geometria, a astronomia e a música (entendida como teoria da harmonia). As artes mecânicas eram as que exigiam esforço físico, frequentemente associadas à arquitetura, à medicina, à arte militar e, uma ou outra vez, ao teatro, à pintura e à escultura. Os pintores e os escultores eram considerados artistas menores, com um estatuto social idêntico ao dos ceramistas, ourives e canteiros.

A partir do Renascimento europeu, com o desenvolvimento do comércio e a formação dos Estados Nacionais, os artesãos tornam-se independentes das corporações. Seus clientes são agora os comerciantes enriquecidos e a nobreza, o que gera alterações significativas na até então concepção clássica de arte. Artes consideradas menores, como a pintura, a escultura, e mesmo a arquitetura, passam a ser valorizadas e separam-se das artes mecânicas, que deixam de ser propriamente arte para se tornarem técnicas. 
É no período renascentista ocidental, portanto, que começa a distinção entre artesão e artista, entre produção artística e produção técnica, entre artesanato e arte. A palavra artista começa a ser usada para denominar exclusivamente os pintores, escultores, arquitetos, poetas e músicos. Para tornar-se artista, a pessoa precisava reunir capacidades especiais, criar obras únicas, inconfundíveis e irrepetíveis: as obras de arte. A criatividade artística não era considerada redutível a regras. Não poderia ser considerado artista aquele que, apesar de ter um bom domínio técnico, seguia as regras inventadas por outros. $\mathrm{O}$ artista passa a ser 0 gênio, imagem que atinge o seu apogeu com o Romantismo.

O atelier artístico do início da Renascença, entretanto, permanece dominado pelo espírito comunitário das corporações medievais, a obra de arte não é ainda personalista. A pretensão de realizar toda obra pelas próprias mãos, do primeiro ao último traço, e a incapacidade para trabalhar conjuntamente com discípulos e ajudantes são observadas pela primeira vez em Michelângelo que, nesse ponto, pode ser considerado o primeiro artista moderno (Hauser, 1969, p. 403).

O artista se afasta do artesão. Os artistas deveriam superar os artesãos, cujos melhores representantes só sabiam repetir com perfeição as regras de habilidade e a destreza dos seus mestres. A fronteira entre o que é arte e o que não é arte 
começa a ser demarcada. Afirma-se que o objetivo da arte é a produção do belo e não a do conhecimento, nem a produção do objeto utilitário, por isso a aritmética, a lógica e a gramática deixam de ser reconhecidas como artes. A função da obra de arte é a de ser manifestação da criatividade do artista na procura da beleza que é oferecida à contemplação do espectador.

Marcel Duchamp vê a aparição da palavra 'arte' ligada à de criação pura como a busca da individualidade e não mais na antiga acepção do sânscrito, por exemplo, quando ela significava 'fazer' e não 'criar' (Frota, 2010, p. 44).

A noção de beleza sempre existiu, mas somente a partir da Renascença é que se impôs como finalidade nas artes e converteu-se em objetivo da pesquisa do artista. Andrade, ao se referir à materialização da beleza na arte ocidental pósrenascentista, afirma que o individualismo se acentua à medida que a beleza se consolida como finalidade e se transforma em objeto de pesquisa de caráter objetivo:

Nem se pode mais decidir com clareza se, nas artes plásticas pelo menos, o individualismo é uma consequência da materialização da 
beleza, ou se esta é uma consequência daquele, de tal forma que ambos se deduzem um no outro (Andrade, 1975).

A distinção entre artes liberais e artes mecânicas foi progressivamente abandonada, mas não tardaram novas classificações. No século XVIII, Kant afirma a distinção entre artes agradáveis e belas artes. As primeiras são as que têm como única finalidade o gozo (os jogos, a gastronomia, as conversas engenhosas). As segundas dão-nos algo mais do que um mero prazer sensorial porque constituem um modo de conhecimento (não científico ou conceitual). As belas artes produzem em nós um prazer contemplativo: puro e desinteressado, que as coloca em um patamar acima do prazer sensorial (considerado como superficial) das artes agradáveis.

É na Renascença, aponta Frota, que se formam as grandes coleções que darão origem ao museu moderno. "Com a dessacralização da sociedade, surge a religião da arte, que tende a transformar os objetos em ícones" (Frota, 2010, p. 44). Foi assim que a arte passou a identificar-se com as belas artes. O francês Satteux propôs uma classificação para as belas artes, formada por sete artes: a pintura, a escultura, a música, a poesia (literatura), a dança, a arquitetura e a eloquência. Rapidamente esta última deixou de ser considerada uma arte. O seu lugar foi 
ocupado, a partir de finais do século XIX e inícios do século XX, pelo cinema, pela arte cinematográfica, por isso mesmo designada como a sétima arte.

\subsection{Os ofícios no Brasil colonial e imperial}

O que se processou no Brasil, a partir da colonização portuguesa, foi bem distinto do que ocorreu na Europa. A possessão rural e o estabelecimento de latifúndios beneficiaram uma economia de base doméstica, de autossuficiência, não favorecendo a organização dos artesãos em corporações, nem a propagação dos ofícios tradicionais no interior das famílias. Pereira (1957b, p. 27) diz que a abundância da mão-de-obra escrava abalou consideravelmente o prestígio do trabalho manual e criou um forte preconceito social contra os ofícios denominados, nessa época, artes mecânicas.

No Brasil do século XVIII, a riqueza do ouro transformou a sociedade. As cidades cresceram e enriqueceram, as construções foram aprimoradas. Vieram da Europa arquitetos, pintores, escultores que conviviam com o estilo barroco europeu e passaram a influenciar os brasileiros nas construções, na arquitetura, na pintura, na escultura e na decoração. 
Em pleno resplendor do ouro, os ofícios eram realizados pelas primeiras gerações que haviam nascido na terra. Na grande mistura da população que se produziu no país, os mulatos desempenharam um papel bastante importante na produção artesanal, constituindo seu exemplo maior a figura de Antônio Francisco Lisboa, o Aleijadinho, mestre da talha barroca. Nessa época, não vigorava a ideia do artífice como criador, o que atesta a falta de assinatura nas produções barrocas.

O barroco brasileiro é um estilo que amadurece e passa a ter um caráter mais popular, principalmente no interior do país, refletindo as tumultuosas aproximações culturais e sociais entre a metrópole e a colônia. Adquire traços indígenas e africanos, além dos europeus. A estética do barroco colonial encontra no Brasil um campo fértil para reinventar-se frente ao clima tropical, às cores e à luminosidade da paisagem.

Algumas corporações de ofício se formaram nos centros mais populosos. Esses grupos obreiros mantinham íntima ligação com as irmandades religiosas, tinham bandeiras, regimentos e um santo patrono. Conservavam a mesma organização medieval de ateliê, em que o mestre coordenava o trabalho coletivo e os aprendizes trabalhavam todos ao estilo do mestre. 
Sob este prisma, o regime muito se assemelhava ao medieval, pois se preservava a boa qualidade do produto em benefício do consumidor, beneficiava também o produtor, garantindo-Ihe uma certa exclusividade profissional, defendendo-o da concorrência ilegítima - desde que mestre algum tinha direito de aceitar uma obra que não fosse rigorosamente de seu ofício e, verificada a infração, a pena cominada ao culpado era a da cadeia, com a de multa, cumulativa, no caso de reincidência, e elevada ao dobro tantas vezes quantas fossem as infrações subsequentes (Pereira, 1957b, p. 31).

As corporações zelavam pela qualificação dos ofícios. Os oficiais de pedreiros, ferreiros, ourives, alfaiates, padeiros e outros deveriam passar por um exame, presidido por um juiz e um escrivão, para obter a carta de ofício, que lhes facilitava o exercício profissional. A instituição das corporações esteve viva entre nós até ser extinta pela Constituição de 1824 (Frota, 2010, p. 49).

É interessante observar que garantir a boa qualidade do produto é uma condição ética que, ainda hoje, continua a existir entre os artesãos e artesãs de Maragogipinho. Quase todos os mestres e mestras com quem conversei enfatizaram este aspecto em sua produção. A pintora Zelita me fez observar duas peças, a dela e a de outra pintora (de quem omitiu a identidade), para saber 
distinguir o bem feito do mal feito. O oleiro Nené destacou que a avidez com que alguns produzem a cerâmica é o que impede a boa qualidade das peças:

Tem uma parte dos artesãos daqui que só quer produzir. Produzir. E minha maneira não é produzir. Eu quero fazer, mas quero fazer bem. Quero que a senhora compre e saia satisfeita. Não quero que a senhora chegue lá e diga: "comprei, não olhei e tá com defeito". Da próxima vez, a senhora não vem: "ele vendeu com defeito".

Voltando à história dos ofícios no Brasil, mais tarde, no início do século XIX, com a chegada da família real portuguesa, a produção artística brasileira se elitiza e recebe forte influência europeia dos artistas da Missão Artística Francesa, contratada por D. João VI. Esse grupo, do qual faziam parte Antoine Taunay, JeanBaptiste Debret e Auguste-Henri de Montigny, organizou a primeira escola de artes brasileira, em 1816, no Rio de Janeiro: a Escola Real das Ciências, Artes e Ofícios, que mais tarde veio a tornar-se a Imperial Academia de Belas Artes e depois a Escola de Belas Artes.

A Escola de Belas Artes se manteve até 1931, quando foi anexada à Universidade Federal do Rio de Janeiro, onde atualmente continua em atividade. Antigos alunos se tornavam mestres e muitos artistas estrangeiros foram atraídos para o seu 
círculo, durante os períodos do Império e da República. Com tendência nitidamente conservadora e acadêmica, manteve-se ao longo do tempo como uma escola que cultuava a arte da elite para a elite, inspirada nos modelos clássicos europeus, em que se ensinavam técnicas com princípios rígidos para o desenho, o uso das cores e os temas. No século XIX, a pintura de temas históricos se tornou a mais prestigiada, seguida pelos retratos oficiais e só depois pelos outros temas como a paisagem e a natureza-morta, numa hierarquização de categorias ligadas a preceitos essencialmente morais e educativos, típicos do Academicismo.

\subsection{Impactos da Revolução Industrial}

Na Europa dos séculos XVIII e XIX, a Revolução industrial caracterizou a substituição do trabalho artesanal manual pelo assalariado com o uso das máquinas, o que contribuiu vigorosamente para a consagração da obra de arte como produto singular. A transferência do trabalho artesanal para o fabril e a produção massiva de artefatos idênticos e destituídos das marcas da mão humana fomentaram um desprestígio crescente ao artesanato. A funcionalidade do objeto converte-se em ideal estético do design: à simplificação das formas, corresponde o mínimo de matéria. 
Paz (1991, p. 49) considera que a produção industrial submete-se a uma racionalidade implacável em busca da justeza de uma fórmula, traduzida na redução da forma para cumprir determinada função. A forma do artefato industrial atende puramente à sua função. O desenho industrial persegue a estética da invisibilidade: os objetos funcionais são tanto mais bonitos quanto menos visíveis.

Na segunda metade do século XIX, surge na Inglaterra um importante movimento estético e social que defende a volta do artesanato criativo como alternativa à mecanização e à produção em massa: o Arts and Crafts Movement. O Movimento das Artes e Ofícios é influenciado por John Ruskin (1819-1900), respeitado crítico de arte e professor nas escolas de desenho do governo inglês, entusiasta defensor do fazer artesanal medieval em contraposição à mediocridade e vulgarização que o processo de produção industrial imprimia nos artefatos e objetos artísticos.

William Morris (1804-1896), artista e escritor, principal articulador do Arts and Crafts, relaciona as ideias de Ruskin às de Marx: a arte deve ser feita pelo povo para o povo. Morris coloca em prática essa concepção em fábricas que projetavam objetos para interiores. Várias associações se organizaram nesse tempo na Inglaterra, ressurgiram os operários-artistas que, em ambientes de 
criação coletiva, projetavam e executavam manualmente os artefatos, imbuídos ideologicamente da missão de estreitar relações entre arte e indústria, função e forma, utilidade e ornamento. As fronteiras entre arte e artesanato foram abrandadas com o ressurgimento das artes manuais em pleno apogeu da era industrial: tecidos tingidos e estampados à mão, produção manual de mobiliário, joias e objetos do dia a dia. A decoração e o design do mundo todo são influenciados até hoje pelo Arts and Crafts.

A sociedade japonesa também não conhecia a distinção entre artesanato e arte até a era Meji (1868-1912), quando se inicia o processo de ocidentalização do país. A modernização tecnológica e a formação de grandes centros urbanos deixaram um grande número de artesãos, com suas produções tradicionais, incapacitados de fazer frente aos produtos industrializados importados dos Estados Unidos e Europa, vendidos a preços inferiores.

A partir de 1920, o filósofo japonês Yanagi Sõetsu (1889-1961), inspirado no Arts and Crafts e nas ideias de William Morris e John Ruskin, idealiza o movimento Mingei e passa a difundi-lo. O termo Mingei é uma abreviatura das palavras Minshu e Kogei, literalmente: "artesanatos populares" e foi cunhado por Yanagi para resgatar o artesanato como patrimônio étnico-cultural japonês, então 
ameaçado pelo processo avassalador de industrialização e ocidentalização. 0 Mingei valorizava o artesanato feito pelo povo. Com o objetivo de reconstruir uma identidade cultural nacional, inspirado na visão budista da beleza, o Mingei resgata a comunhão entre o belo e o útil nos objetos feitos à mão, defende o fazer coletivo e o anonimato do artesão, em contraposição ao surgimento e exaltação do gênio artístico do ocidente e sua produção individual. "A beleza pode existir sem heróis", costumava dizer Yanagi (1972). A consolidação do Mingei contou com a colaboração efetiva dos ceramistas Hamada Shoji (1894-1978), Kawai Kanjiro (1890-1966) e do inglês Bernard Leach (1887-1979).

No ocidente, surge a Bauhaus, uma escola de artes aplicadas, fundada por Walter Gropius em 1919, em Weimar, na Alemanha. Igualmente inspirada no Arts and Crafts, a Bauhaus representou um verdadeiro celeiro da arte e cultura europeias, foi um centro de pesquisa e ensino da arquitetura que resgatou a prática artesanal, propondo a unidade entre as diferentes artes e ofícios, sob a égide do design e da arquitetura. O programa de ensino da Bauhaus era de caráter acentuadamente prático, organizado em oficinas de construção em que se usavam diversos materiais, mas, ao mesmo tempo, o estudo da natureza, da geometria, do desenho, da economia não eram descuidados. 
Gropius não acreditava na separação entre as artes decorativas e as belas artes. 0 manifesto Bauhaus, escrito por ele em 1919, propõe o retorno ao modo artesanal de produção, compreende a produção artística articulada na integração e na prática das artes e refuta a divisão entre artista e artesão:

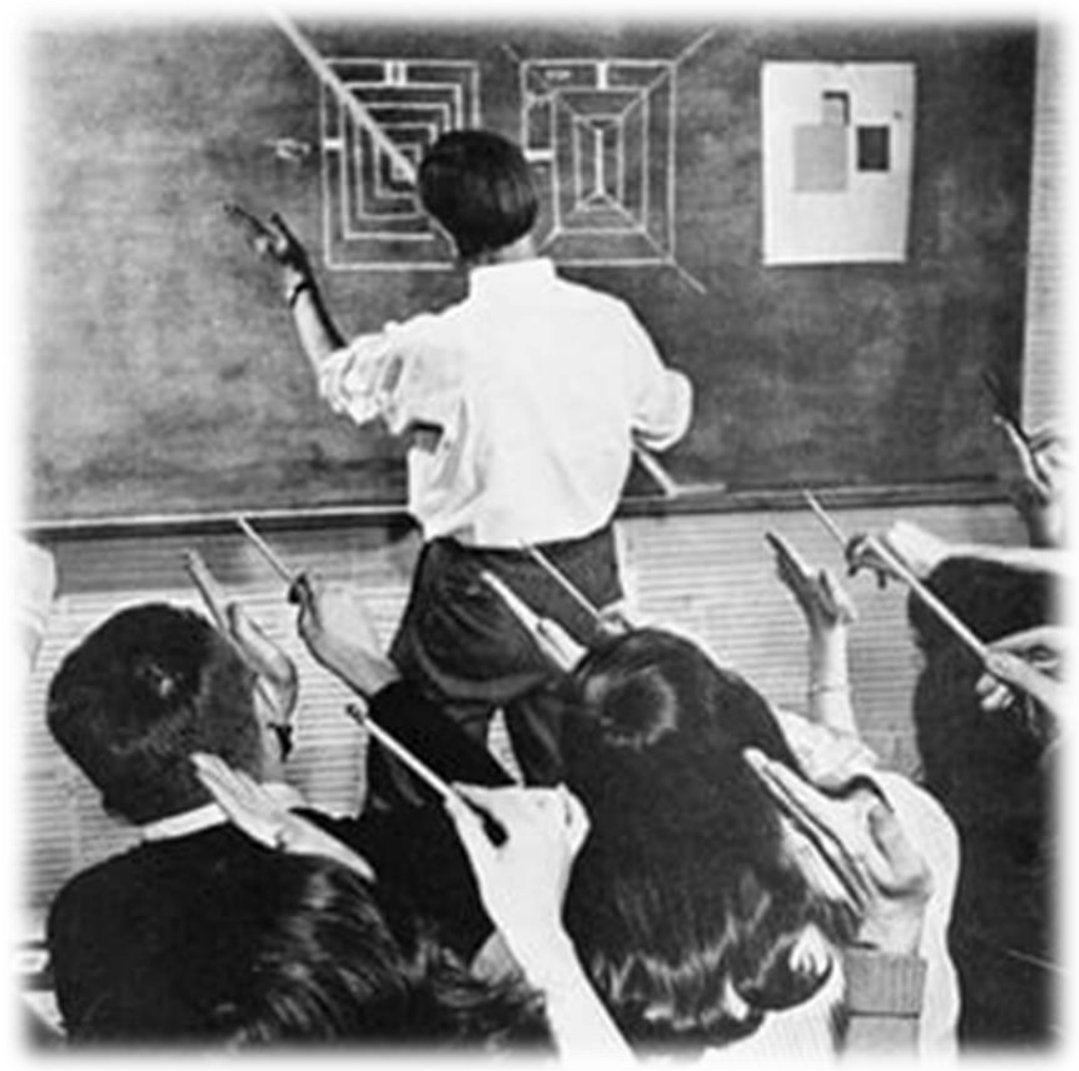

Josep Albers (1888-1976), professor da Bauhaus

(http://media.bauhaus-movement.com/) 
O fim último de toda a atividade plástica é a construção. (...). Arquitetos, pintores e escultores devem novamente chegar a conhecer e compreender a estrutura multiforme da construção em seu todo e em suas partes; só então suas obras estarão outra vez plenas de espírito arquitetônico que se perdeu na arte de salão. As antigas escolas de arte foram incapazes de criar essa unidade, e como poderiam, visto ser a arte coisa que não se ensina? Elas devem voltar a ser oficinas. Esse mundo de desenhistas e artistas deve, por fim, tornar a orientar-se para a construção. Quando o jovem que sente amor pela atividade plástica começar como antigamente, pela aprendizagem de um ofício, o 'artista' improdutivo não ficará condenado futuramente ao incompleto exercício da arte, uma vez que sua habilidade fica conservada para a atividade artesanal, onde pode prestar excelentes serviços. Arquitetos, escultores, pintores, todos devemos retornar ao artesanato, pois não existe 'arte por profissão'. Não há nenhuma diferença essencial entre artista e artesão, o artista é uma elevação do artesão, a graça divina, em raros momentos de luz que estão além de sua vontade, faz florescer inconscientemente obras de arte, entretanto, a base do "saber fazer" é indispensável para todo artista. Aí se encontra a fonte de criação artística. Formemos, portanto, uma nova corporação de artesãos, sem a arrogância exclusivista que criava um muro de orgulho entre artesãos e 
artistas. Desejemos, inventemos, criemos juntos a nova construção do futuro que enfeixará tudo numa única forma: arquitetura, escultura e pintura que, feita por milhões de mãos de artesãos, se alçará um dia aos céus, como símbolo cristalino de uma nova fé vindoura (Gropius, 1919).

Em 1926, a escola muda-se para Dessau e depois para Berlim, até ser dissolvida em 1933. Desde o início, a Bauhaus contou com a colaboração de artistas plásticos. Gropius conseguiu reunir um corpo docente formado por mestres como Wassily Kandinsky, Paul Klee e Oskar Slemmer. Seu legado ainda encontra eco em projetos de desenho industrial e de design da atualidade.

\subsection{A produção artesanal no Brasil moderno}

A América Latina e o Brasil do início do século XX importam com voracidade o ideário racionalista europeu pós-Revolução Industrial. O desejo deliberado de abolir o objeto feito à mão correspondia a um anseio modernizador que considerava as manualidades como ofícios do passado, do subdesenvolvimento, do atraso. O design erudito brasileiro nasce da ruptura com os saberes ancestrais do povo. O historiador Rafael Cardoso observa que houve uma importação acrítica 
das ideias bauhasianas por países latino-americanos como a Argentina, o Chile e o Brasil:

A experiência da Bauhaus acabou contribuindo para a consolidação de uma atitude de antagonismo dos designers com relação à arte e ao artesanato. Apesar de ser uma escola cheia de artistas e artesãos - ou talvez por causa disso - acabaram prevalecendo aquelas opiniões que buscavam legitimar o design ao afastá-lo da criatividade individual e aproximá-lo de uma pretensa objetividade técnica e científica (Cardoso, apud Borges, 2011, p.63).

A industrialização do país e o nacionalismo favorecem o interesse pelas culturas das classes populares. Surge o termo folclore, cunhado na Inglaterra por William Jonh Thoms, para designar os saberes dos estratos da população de baixa renda. Nos estudos sobre folclore brasileiro se destaca, como precursor das pesquisas e resgates das tradições populares, o filósofo, crítico literário e poeta Silvio Romero (1851-1914). É o primeiro pesquisador a atribuir valor a uma produção cultural que, até aquele momento da história nacional, não era reconhecida como expressão de um povo. 
Quase uma década após a morte de Silvio Romero, o movimento modernista brasileiro, que ganha expressão pública na Semana de 22, retoma valores da arte tradicional e do fazer artesanal. Com expressiva atuação e liderança no movimento, o poeta, romancista, crítico de arte, musicólogo, professor universitário e ensaísta Mário de Andrade (18931945), reconhecido como o mais importante intelectual brasileiro do século XX, buscou uma profunda compreensão do folclore em diálogo com as ciências humanas e sociais, então nascentes no Brasil.

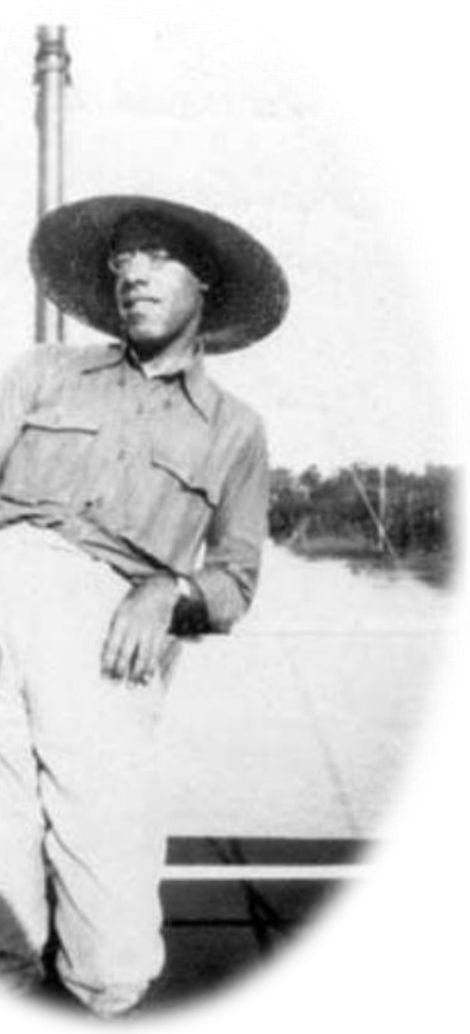

Mário de Andrade em viagem à Amazônia (Acervo do Instituto de Estudos Brasileiros - USP)

Em 1938, a frente do Departamento de Cultura da cidade de São Paulo, Mário de Andrade reúne uma equipe com o objetivo de viajar aos recônditos do país e catalogar músicas do Norte e Nordeste brasileiros. A Missão de Pesquisas 
Folclóricas resultou em um vasto acervo registrado em vídeo, áudio, imagens, anotações musicais, dos lugares percorridos pela equipe, o que pode ser considerado como um dos primeiros projetos multimídia da cultura brasileira.

As décadas de trinta e quarenta do século passado foram emblemáticas de uma primeira revisão do eurocentrismo (Carvalho, 2010). Esse modelo de incorporação da diversidade cultural do país admitia o símbolo indígena ou africano, porém se absorvido pelo padrão epistêmico ocidental. O modernismo brasileiro foi paradigmático dessa absorção seletiva e excludente. Segundo o autor, "os conhecimentos tradicionais eram documentados e mesmo digeridos, mas os criadores e detentores desses conhecimentos continuavam de fora do processo decisório e também do acesso pleno aos bens e serviços que o Estado concedia a esses intelectuais sensíveis à diferença estética cognitiva e simbólica até então negada" (Idem, p. 4).

Em 1947, na Biblioteca Castro Alves do Instituto Nacional do Livro, no Rio de Janeiro, é inaugurada a "Exposição de Cerâmica Popular Pernambucana", tornando pública a obra de uma dos maiores ceramistas figureiros do país: Vitalino Pereira dos Santos (1909-1963), conhecido como Mestre Vitalino. Essa exposição é emblemática na história da arte no Brasil porque representa o início da 
descoberta das artes populares pelas elites intelectuais: "a passagem dessas figuras de barro para a categoria do estético corresponde a uma mudança nas mentalidades provocada pelas transformações na vida socioeconômica e cultural do país, concomitantemente ao desenvolvimento industrial" (Frota, 2010, p. 54).

No mesmo ano em que ocorre a exposição de Vitalino, é criada a Comissão Nacional de Folclore que consolida sua atuação institucional em 1958, transformando-se em Campanha de Defesa do Folclore Brasileiro, órgão subordinado ao Ministério da Educação e Cultura. Em 1980, passa a denominar-se Instituto Nacional do Folclore e hoje constitui o Centro Nacional de Folclore e Cultura Popular, órgão do IPHAN, Ministério da Cultura, com sede na cidade do Rio de Janeiro. 


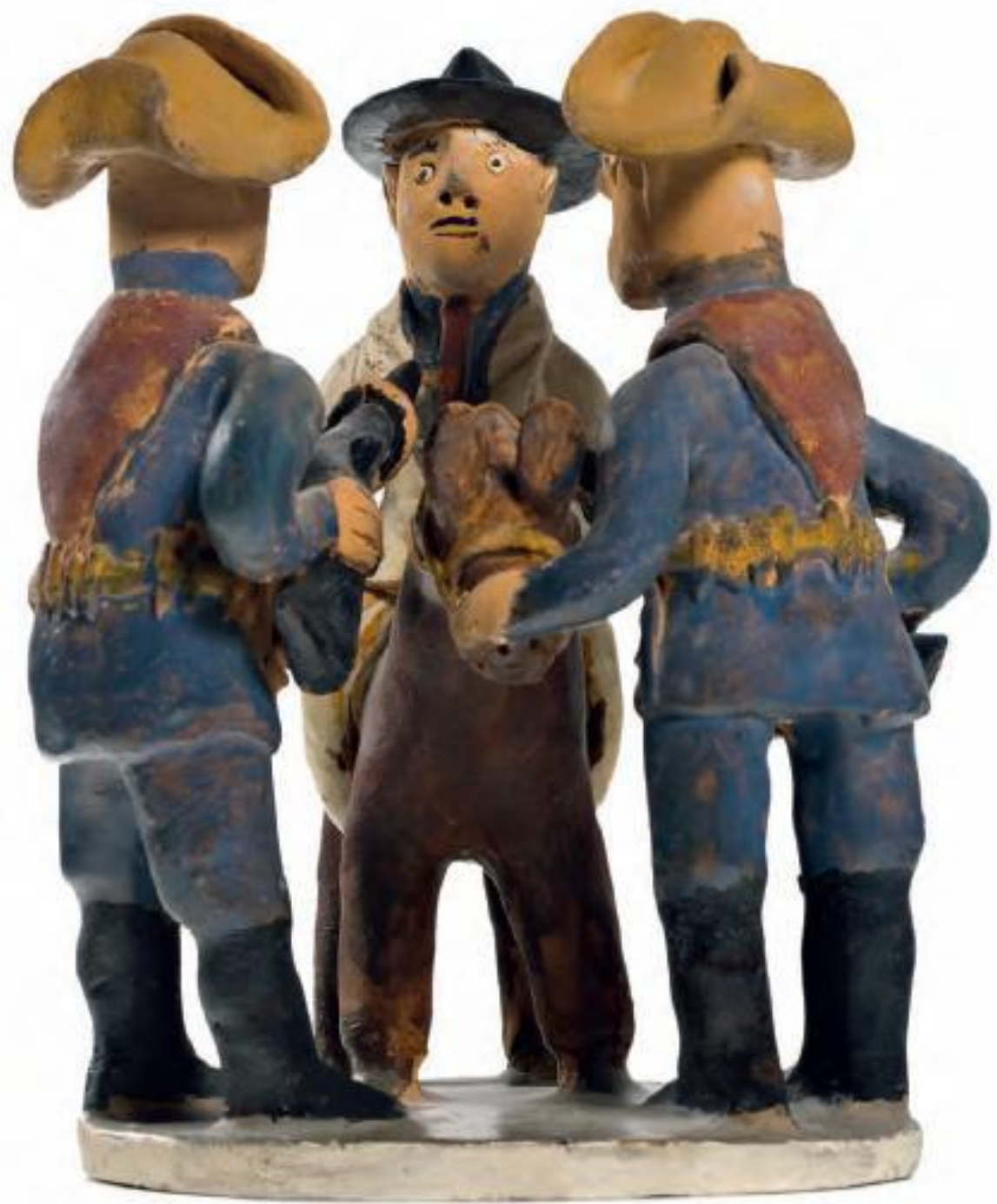

Mestre Vitalino - “Emboscada”

Reprodução fotográfica: Soraia Calrs/ Evandro Carneiro 


\subsection{Ambiguidades na fronteira entre artesão e artista}

Muito embora o campo de estudos do folclore tenha consolidado uma nova visão dos ofícios artesanais, atualmente, no Brasil, a ruptura entre artesanato e arte continua a ser justificada por visões hegemônicas e etnocêntricas. Por isso, as belas artes seguem consideradas por muitos como eruditas e universais e as artes populares, produzidas nas ruas, na periferia das grandes cidades e no interior do país, classificadas como primitivas.

Hoje, na esteira do Modernismo, proliferam políticas de valorização dos conhecimentos das comunidades tradicionais, entretanto a maioria dessas políticas orienta-se para uma espécie de multiculturalismo unilinear, em um movimento de mão única, ou seja, é a cultura ocidental que detém os parâmetros para valorizar a diversidade que inclui o não ocidental.

Valores artísticos renascentistas sobrevivem entre nós: algumas pessoas acreditam que a arte é pura imaginação e criatividade do artista e que, secundariamente, necessita de conhecimentos técnicos e habilidades. Para elas, a obra de arte é única e irrepetível, deve possuir a estirpe inconfundível do seu criador. A marca distintiva da obra é a originalidade, a autonomia, a inutilidade, ou 
seja, ter um fim em si mesma sem ter de adaptar-se a alguma função. Reduzem o artesanato, por sua vez, à mera atividade manual isenta de criatividade, baseada na reprodução e aplicação de conhecimentos e de regras técnicas.

Na opinião de Coomaraswamy, não se pode estabelecer distinção estrita entre uma arte bela e inútil e uma arte aplicada e útil, muito menos entre as artes cultas e as populares. As diferenças que há entre elas se restringem mais à elaboração às vezes, ao refinamento - do que ao conteúdo. O artista não difere do homem comum:

Ainda que possamos encontrar-nos com leis suntuárias, correspondentes à hierarquia funcional, as necessidades fundamentais da vida, sejam físicas ou espirituais, são as mesmas para todas as classes. Portanto, os usos e significado das obras de arte nunca necessitam ser explicados, pois o artista não é distinto do homem, mais que pela possessão de um conhecimento específico e uma tecnica específica (Coomaraswamy, 2001, p. 18-19).

No âmago da cisão entre artesão e artista está a separação entre trabalho intelectual e manual. O artista contemporâneo, de alguma forma, busca um lugar de distinção intelectual na sociedade, apartado da classe operária. Já o artesão 
considera-se um operário e assume a condição de ter de comercializar sua obra, fator imprescindível para a sua sobrevivência e que marca a ambiguidade de sua posição social.

Para o oleiro Nelinho Mota, de Maragogipinho, artesão e artista encontram-se reunidos em uma mesma pessoa:

Eu acho que o artista tem que estar no artesão e o artesão no artista. 0 artesão está no trabalho mais árduo, nessa coisa de ter que produzir porque é o nosso meio de sustento, de sobrevivência. E o artista está naquela outra parte de você criar algo que encante, certo? Que as pessoas cheguem e gostem. (...). É como esta peça aí, eu não tenho compromisso nenhum com ela, não terminei, não sei quando vou terminar e eu fico tranquilo, não quero vender ela assim, quero até terminar... Então, esse é um pouco do artesão misturado com o artista.

Mário de Andrade (1975) defendia que uma forma para a superação do individualismo típico da modernidade estava em fazer o artista retornar à sua vocação artesanal original, que não há distinção entre artesanato e arte porque ambos constituem fazeres submetidos ao material e às suas determinações. 
A discussão que tenta diferenciar artesão e artista é profundamente complexa porque envolve juízos de valor, hegemonia e divisão de classes. Evidentemente, não almejamos aprofundá-la neste trabalho. Durante a pesquisa de campo, o contato mais estreito que mantive com os oleiros e as pintoras de Maragogipinho me permitiu, apoiada em Andrade, religar os significados amalgamados das duas palavras.

Artista que não seja bom artesão, não é que não possa ser artista: simplesmente, ele não é artista bom. E desde que vá se tornando verdadeiramente artista, é porque concomitantemente está se tornando artesão (Andrade, 1975, p. 47).

Concordamos com Porto Alegre quando afirma que:

Toda a discussão sobre fronteiras entre 'arte' e 'artesanato', entre 'artista' e 'artesão', a partir do discurso dominante, carece de sentido dentro da perspectiva do indivíduo que exerce essa atividade, pois ele raramente separa a instância do trabalho manual ou mecânico (artesanal) do trabalho intelectual e confere a ambos igual dignidade (Porto Alegre, 1985, p. 10). 
Por isso, nossos sujeitos são artesãos e artesãs, pessoas que trabalham e produzem artefatos com as mãos.

Diante da extensão das mudanças do mundo contemporâneo, do modelo de sociedade calcado no consumo desenfreado e na apropriação depredatória dos recursos naturais, esses artesãos e artesãs não são, absolutamente, agentes passivos. Seus fazeres e modos de vida mudam e se atualizam constantemente. No entanto, possuem uma incrível capacidade de resistência, uma "teimosia resiliente", como afirma Montes (2014, p.21), pois seus saberes passam constantemente pela prova do tempo e da experiência, e sobrevivem em modos de vida regulados pela harmonização entre homem, natureza e tempo. 
Estavam na olaria, alinhados na bancada os seis bonecos pareciam aquilo que dramaticamente eram, seis objetos insignificantes, mais grotescos uns do que outros pelo que representavam, mas todos iguais na sua lancinante inutilidade. A fim de que o marido pudesse vê-los, Marta havia retirado os panos molhados que os envolviam, mas quase se arrependia de o ter feito, era como se aqueles obtusos manipansos não merecessem o trabalho que tinham dado, aquele repetido fazer e desfazer, aquele querer e não poder, aquele experimentar e emendar, não é verdade que só as grandes obras de arte sejam paridas com sofrimento e dúvida, também um simples corpo e uns simples membros de argila são capazes de resistir a entregar-se aos dedos que os modelam, aos olhos que o interrogam, à vontade que os requereu. Saramago, 2000, p. 166. 


\section{Potes no interior de uma olaria}

(https://farm4.staticflickr.com/3272/2551718940_c9eb2aef28_z.jpg?zz=1) 


\section{A VOZ SILENCIOSA DOS OBJETOS}

Barriga de mulher grávida, pescoço de pássaro. Se lhe tapas e destapas a boca com a palma da mão, ela te responde com um murmúrio profundo,

borbotão de água brotando; se Ihe golpeias a pança com os nós dos dedos,

solta um riso de moedinhas de pratas caindo sobre as pedras.

Tem muitas línguas,

fala o idioma do barro e do mineral, o doar correndo entre as muralhas do vale, o das lavadeiras a lavar, o do céu quando se zanga.

O da chuva.

Octávio Paz

Desde que vi pela primeira vez uma fotografia de Maragogipinho, senti que havia naquele lugar várias camadas de significados a serem descortinadas. Nas duas ocasiões em que lá estive, confirmei a sensação inicial de espessura. A visão de objetos de barro por toda parte transporta o visitante para outra dimensão. Os potes, vasos, panelas, pratos, jarras, porcos, bois, burrinhos, além de povoarem o interior das olarias, se estendem pelas calçadas e ruas, nos carrinhos de mão das 
crianças, nos parapeitos das janelas, no chão das varandas, nos quintais, na beira do rio, no colo das brunideiras e pintoras, em cima dos telhados.

As vozes silenciosas desses corpos cerâmicos clamam por um olhar mais agudo, que alcance as suas profundezas, muitas delas impenetráveis para o pesquisador. Bachelard revela que toda a matéria imaginada, meditada, torna-se imediatamente a imagem de uma intimidade:

Esta intimidade é considerada remota; os filósofos nos explicam que ela será sempre oculta, que mal se retira um véu, estende-se um outro sobre os mistérios da substância. Mas a imaginação não se detém ante essas boas razões (Bachelard, 2003, p. 3).

Um vaso ou um boneco de barro podem encerrar mistérios indizíveis: "A terra é um elemento muito apropriado para ocultar e manifestar as coisas que lhe são confiadas" (Le cosmopolite, apud Bachelard, 2003, p. 1). 


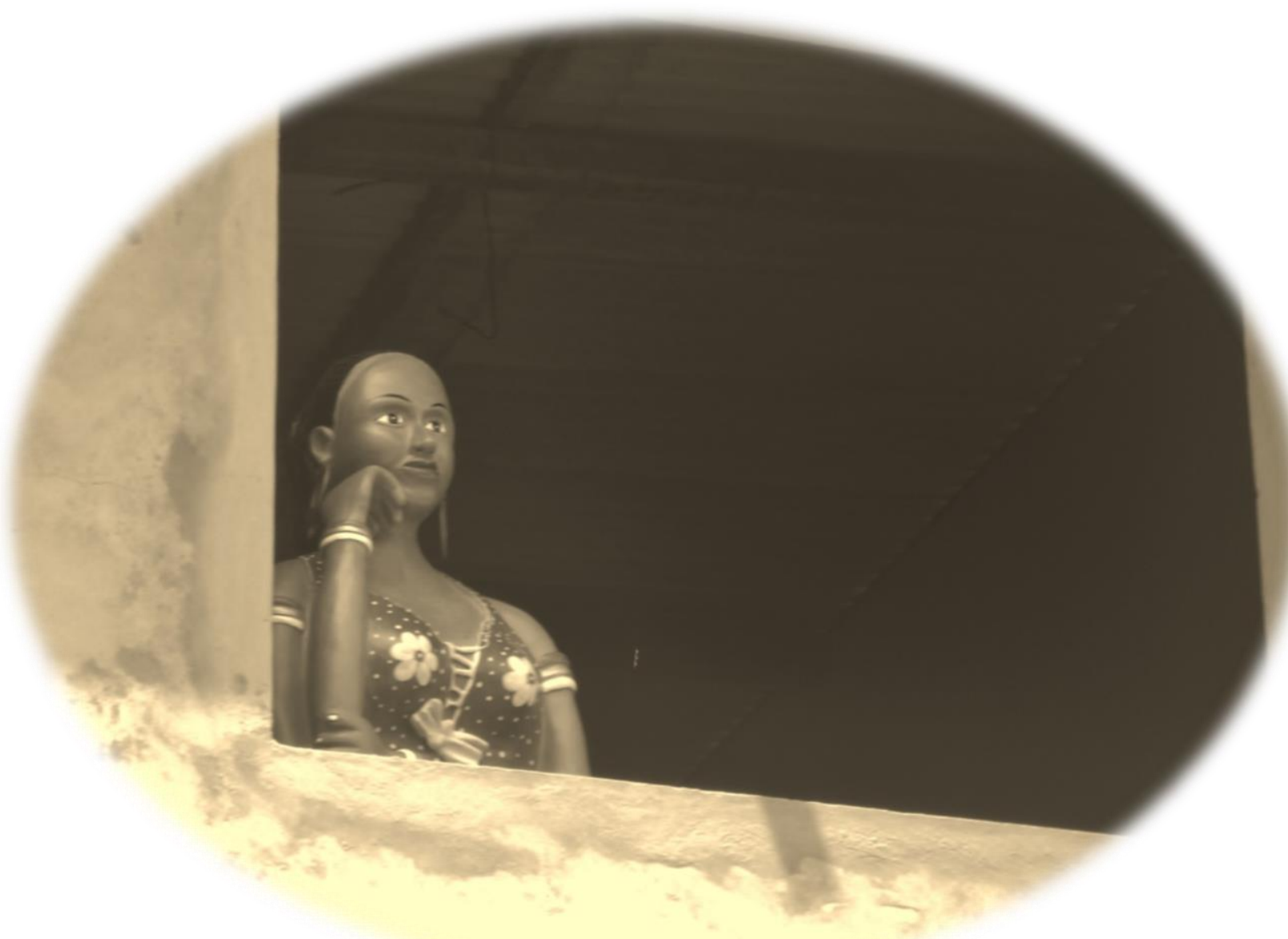

Boneca de barro na janela da olaria de Seu Zé

Os objetos de barro convivem intimamente com as pessoas e os animais nesse povoado, resguardando a sua paisagem da vertigem imagética dos objetos 
industrializados do mundo urbano, trazendo a sensação amena de que a voracidade do consumo e a velocidade com que as mudanças ocorrem nas cidades encontram ali um escudo. De um ano para o outro, é certo, percebi alterações visíveis no cenário do povoado: o calçamento dos caminhos entre as olarias, a pintura de uma ou outra casa, a construção de uma olaria com blocos, porém permanecia a impressão de que estava suspensa em uma esfera diferente de tempo e de espaço. Ali, uma atmosfera de ancestralidade emana da terra, e essa atmosfera só aos poucos se desanuvia e se revela ao visitante, como se o povoado fosse se abrindo lentamente à visualização das camadas de integridade que envolve natureza, homem e sociedade.

No mangue, nos fundos das olarias, em terrenos baldios avistei fragmentos desses objetos, cacos de peças cerâmicas que pereceram e foram descartadas. Da terra nasceram e à terra voltaram. Diferentemente do plástico (matéria onipresente e eterna), com o tempo, os cacos se decompõem e se reintegram ao meio ambiente.

Muito ao contrário dos artefatos industrializados, os produtos artesanais não se propõem à permanência. Podem durar, mas podem desaparecer, sem que sua perda seja irreparável. Não ensinam apegos, ensinam a 
vida - pois nasceram para ser parte da vida, como o homem que os faz e, portanto, como ele, são perecíveis (De Vives, 1983, p. 138).

O passado transpira em Maragogipinho, assim como a água represada em um pote de barro. A argila permanece sendo processada, torneada, modelada e queimada, por meio de formas seculares de produção e organização do trabalho, numa cadeia produtiva em que cada atividade deve completar-se para passar à seguinte. $\mathrm{O}$ artesão e a artesã executam uma parte do trabalho sem perder a dimensão do todo, detêm técnicas e executa ações que causam transformações radicais no material.

Son actos profundos porque operan una metamorfosis en cada fase: de materia prima en su estado natural a material maleable, y de objeto formado a objeto decorado y terminado (Turok, 1988, p. 56).

Ao conectar sujeitos e mundo, os objetos cerâmicos narram camadas de significados éticos e estéticos, neles ressoam a metamorfose da matéria, a gestualidade dos autores, os processos de sua feitura e o modo como são usufruídos no cotidiano. 
O objeto reflete simbolismo que envolve universos mentais, em atribuições de sentidos caracterizados por fluxos imagéticos de diferentes graus de subjetividade, desde simples experiências de "estar no mundo" até a aura criada pelo próprio artefato, em sua condição de ícone, na tarefa de comunicar experiências culturais (Dohmann, 2010, p. 72).

Em Maragogipinho, a produção de objetos permanece voltada para os artefatos domésticos e religiosos, utilitários que vêm perdendo a sua função, alguns viram objetos

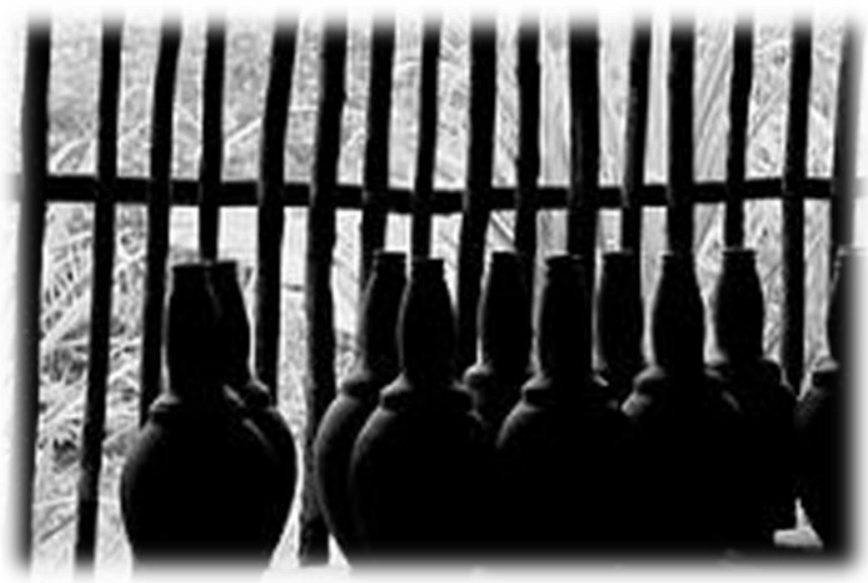

decorativos, que, por Moringas insistência ancestral, continuam a ser fabricados manualmente. São inúmeras as peças utilitárias confeccionadas por lá, para atender a uma demanda local intensa. Nas olarias e lojas do vilarejo, podemos encontrar esses utensílios para a venda, classificados em diferentes tamanhos. 
O porrão e a talha são objetos consagrados pelo tempo, que servem para armazenar água.

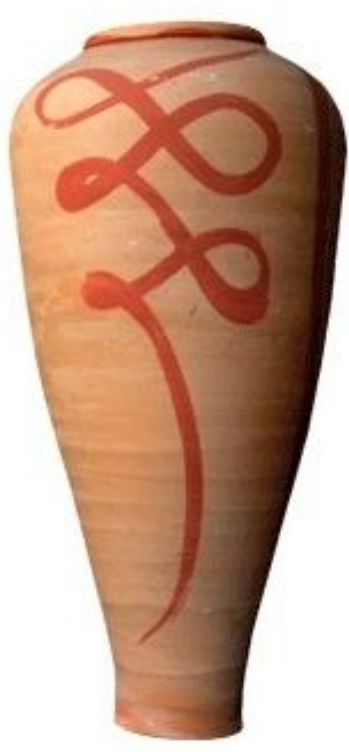

Porrão

(Oleiro: Nené)

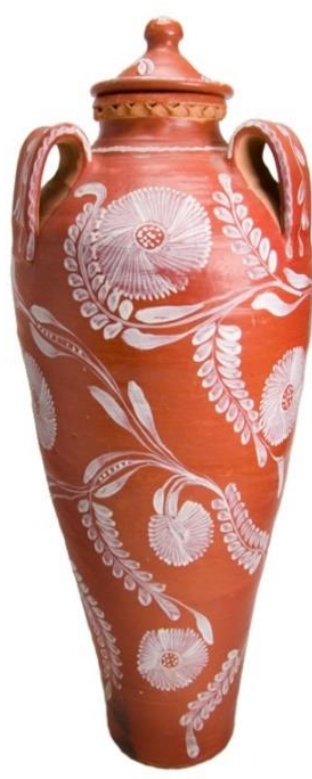

Talha

(Oleiro: Miro/ Pintora: Zelita)

Nelinho explica a diferença entre os dois, na função e na forma: 
O porrão, que é o rústico, era pra colocar água para gastos. Porque como não existia tanque de PVC, esse era de água para banho, para gastos normais da casa. A talha era específica para água de beber e cozinhar os alimentos. Numa casa, qualquer pessoa que chegava via um porrão e uma talha. $O$ porrão é o que não tem polimento nenhum. $A$ talha é toda polidinha, a que tem as alças do lado com a tampinha. $O$ porrão tem aqueles desenhos bem africanos. Já na talha as pinturas são bem portuguesas, este vermelho e branco, estas flores, o desenho é bem português.

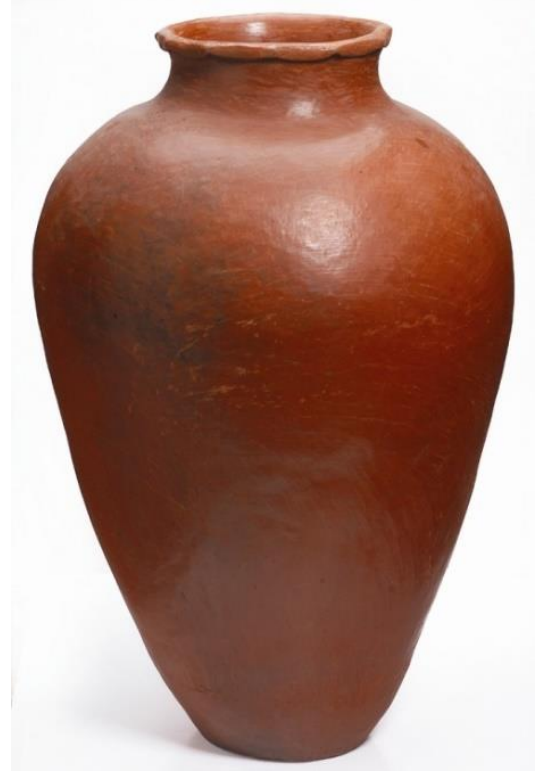

Bujão
A talha é um objeto que continua a ser produzido em larga escala. O oleiro Tutuna me mostrou vários tamanhos de talhas: talhinha zero, $\mathrm{n}$ 을 $1, \mathrm{n}$ 은 $2, \mathrm{n} 03$, talha pequena, meia-talha, talha grande. As maiores são comercializadas atualmente para fins decorativos. As menores são amplamente requisitadas pelos devotos da umbanda e do candomblé para as lavagens e outras finalidades religiosas. 
O bujão tem a forma de um bojo, é também torneado em tamanhos diversos, assim como ocorre com o quartião e a quartinha, artefatos utilizados em rituais de candomblé: tiriri (pequena), obrinha, quartião pequeno, quartião médio, quartião grande, quartião GG $(90 \mathrm{~cm})$. A variedade é imensa: potes, panelas, pratos, travessas, moringas, alguidares, bilhas, bois-bilhas, baianas, bonecas, animais, luminárias, lajotas, incensadores, caqueiros (vaso para plantas), mealheiros. Cada artesão imprime variações nas formas originais desses objetos: detalhes, alças, bocas, pés e, dessa maneira, proliferam e se multiplicam estilos variados de modelagem e pintura das peças tradicionais.

Alguns desses utensílios tiveram lugar de destaque no Brasil do passado, usados em residências de classe média e em solares aristocráticos, ao lado da mais fina porcelana europeia. Pereira (1957a, p. 62) conta que as quartinhas eram artigos de primeira necessidade na casa de nossos bisavós e que seu uso se estendeu até mais ou menos a metade do século XX. Tinham dupla finalidade: servir de copo e refrescar a água. Para elas havia no mobiliário das casas o "quartinheiro" ou "aparador", um tipo de estante com duas prateleiras: as moringas ficavam em cima e as quartinhas (uma para cada membro da família) em baixo. O autor descreve alguns desses móveis como suntuosos, torneados em madeira jacarandá, com a parte superior coberta de mármore. 


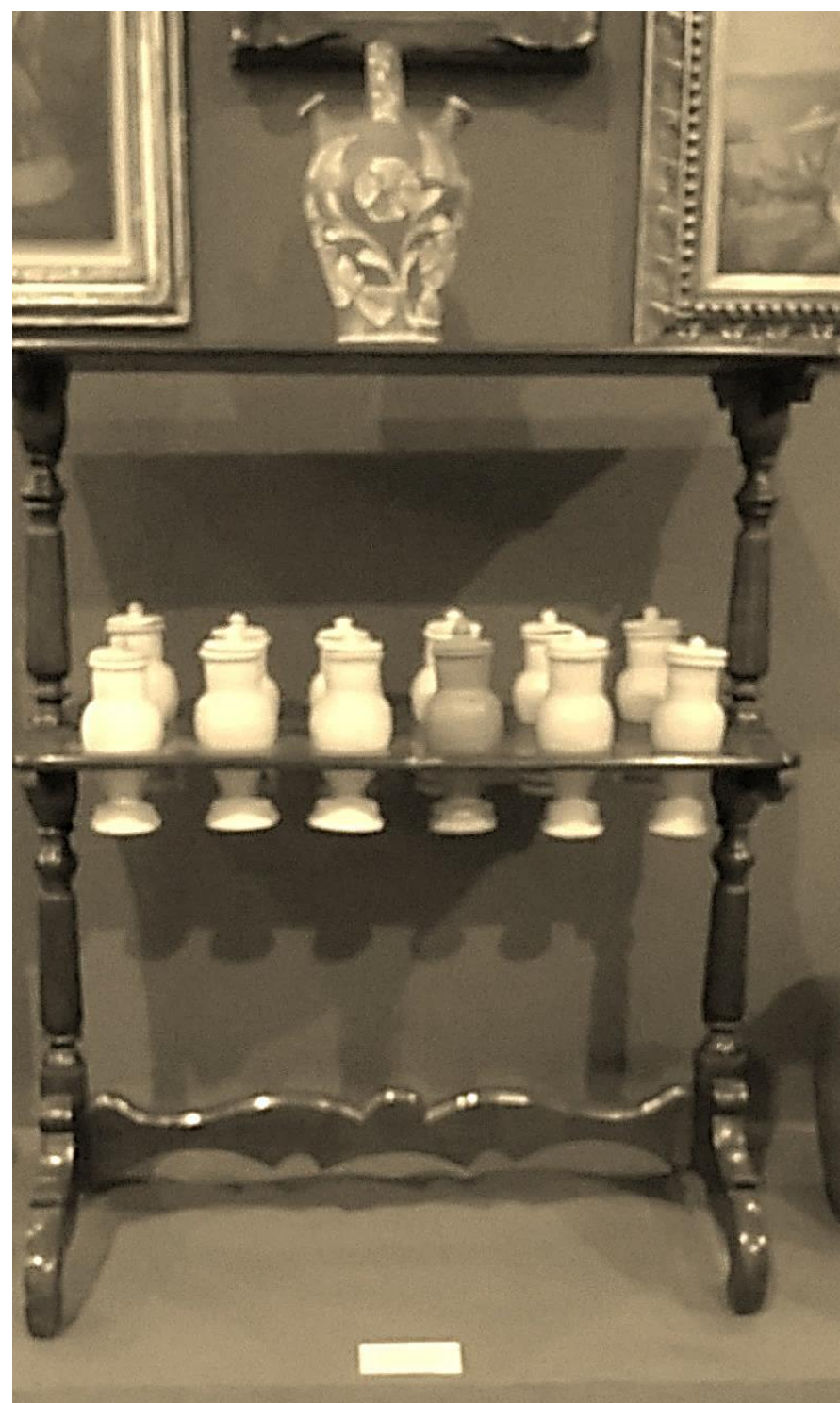

Quartinheiro

(Acervo Museu Afro-Brasil) 
Nos lares mais humildes havia também um mobiliário específico para guardar os objetos de barro essenciais do dia a dia. Nelinho lembra que convivia com eles na casa do seu avô:

Eu lembro que na casa de meu avô, tinha um suporte de madeira com um pezinho, onde se encaixava a talha no meio. $\mathrm{O}$ do porrão era um pezinho de ferro.

Em um passado recente, os objetos de barro para conter água eram artigos dotados de afetividade, como enaltece o mexicano Dr. Atl, em 1922:

El jarro ocupa un lugar proeminente en todas las vendímias de los mercados y fiestas populares, decora las cocinas, es eterno compañero del mendigo, consuelo del prisionero, vasija indispensable en todos los hogares, prenda de amor entre los amantes pobres... crátera donde se vacía la pasión - o donde nace - entre las viscosidades del pulque ${ }^{6}$ (Dr. Atl, apud Turok, 1988, p. 65).

Os porrões, talhas, jarras, moringas foram utensílios essenciais quando não havia água potável dentro de casa e seguem sendo usados hoje em muitos locais onde

${ }^{6}$ Bebida alcóolica feita do suco fermentado do agave, consumida em larga escala na Mesoamérica. 


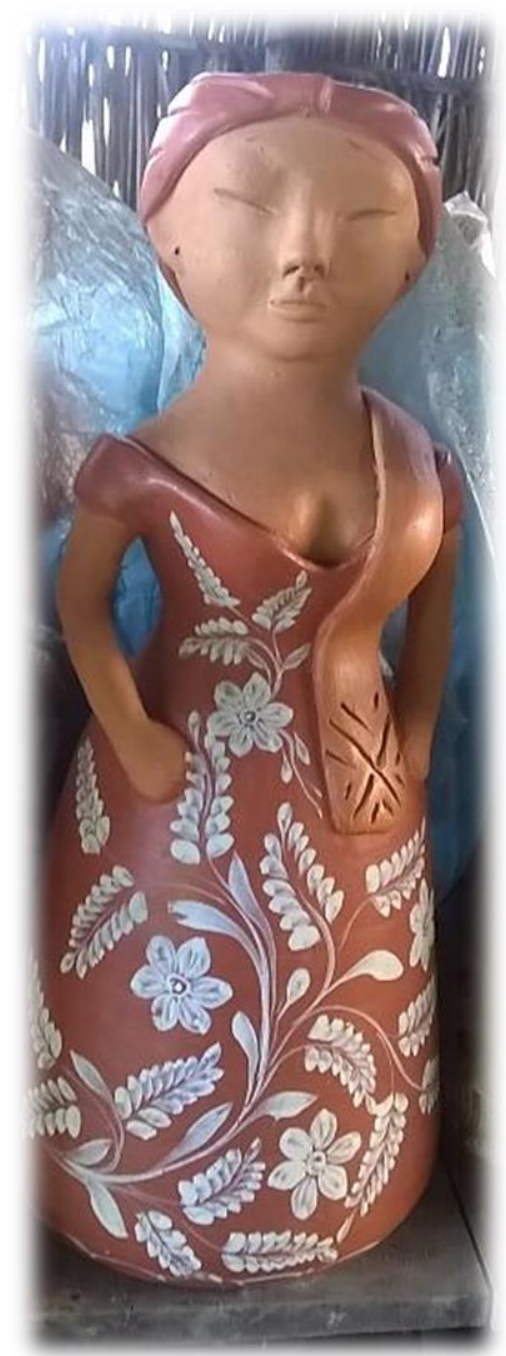

Baiana

(Oleiro: Padre) ainda não há água em torneiras. Caracterizam-se, em primeiro lugar, como "objetos-continentes" porque impedem que o líquido que contêm se derrame. Como? Seu corpo possui uma base, um bojo e um pescoço com a boca pequena. Quando o líquido é vertido, essa boca precisa direcioná-lo para que não escorra pelo pescoço.

Uma segunda característica é que não podem ser objetos pesados porque são carregados, na maioria das vezes, por mulheres, que os acomodam na cabeça ou no ombro para transportar por largas distâncias o líquido que encerram. As alças, ou asas, ajudam a levantá-los e a abaixá-los.

Em terceiro lugar, além da beleza que deles emana, a sua água é deliciosamente fresca porque o calor transpira pelas paredes do barro cozido. Por séculos, os objetos criados pela mão atenderam a fins utilitários e estéticos, concomitantemente. 
Em Maragogipinho, juntamente com os utensílios coexistem objetos antropomorfos, como as tradicionais baianas e zoomorfos como o boi-bilha e o porco-cofre. $\mathrm{O}$ boi-bilha é pintado com tauá e tabatinga e confeccionado em diversos tamanhos.

O boi-bilha é reconhecido nacionalmente e internacionalmen-te como um símbolo de Maragogipinho. Foi criado pelo oleiro Vitorino Moreira, hoje com 95 anos, com quem conversei longamente. Contou-me que queria inventar uma coisa diferente, então viu o boi de Mestre Vitalino, ceramista pernambucano, já falecido. Adaptou a bilha, artefato tradicional de origem portuguesa, puxando um dos lados para compor a cabeça do boi e o outro para formar o rabo. O boi de Vitorino, pintado no tauá e na tabatinga, recebeu menção honrosa da ONU em 2004, no Festival de Artesanato dos Países da América Latina e Caribe. 


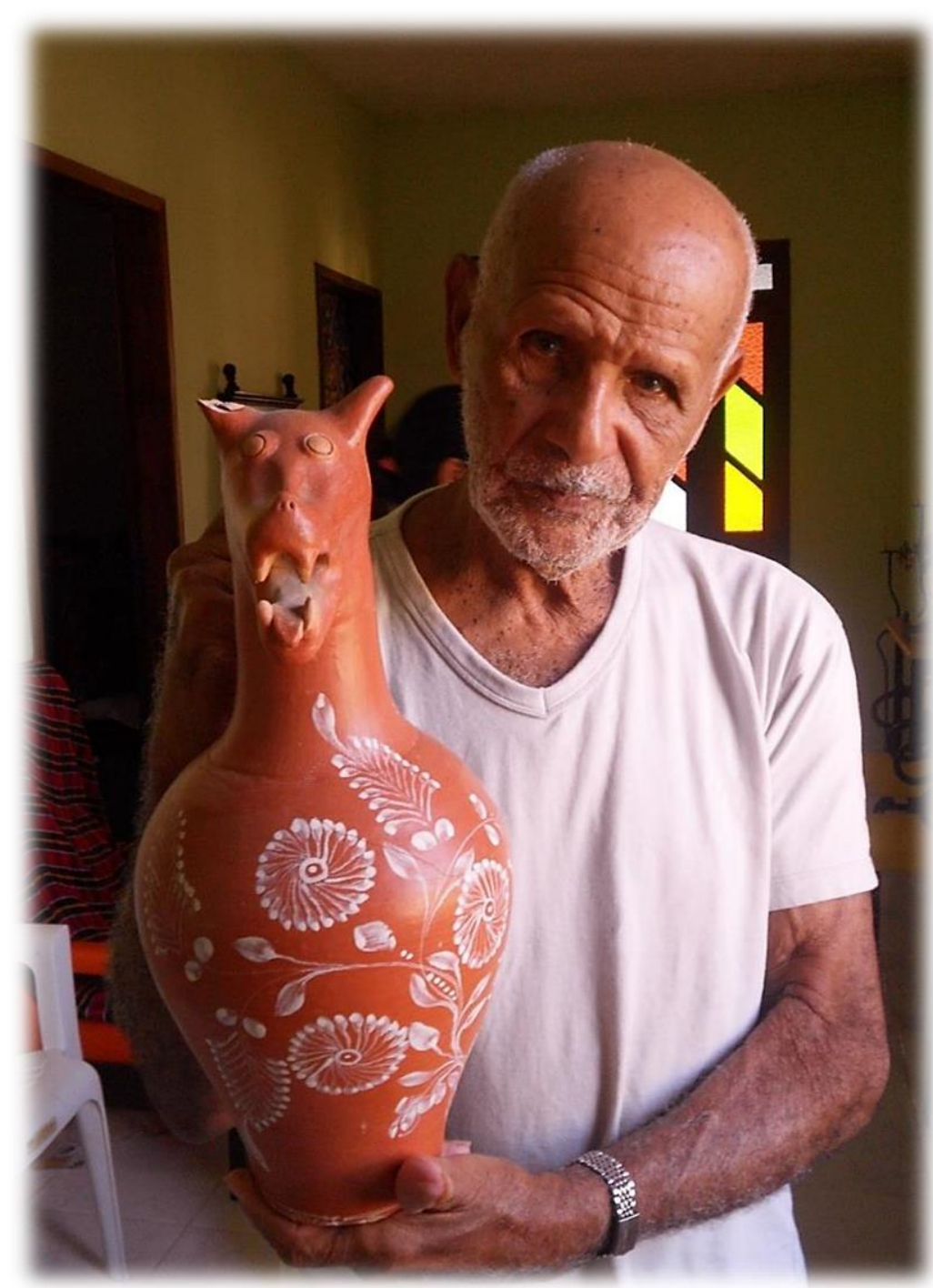

Mestre Vitorino com seu boi-bilha 


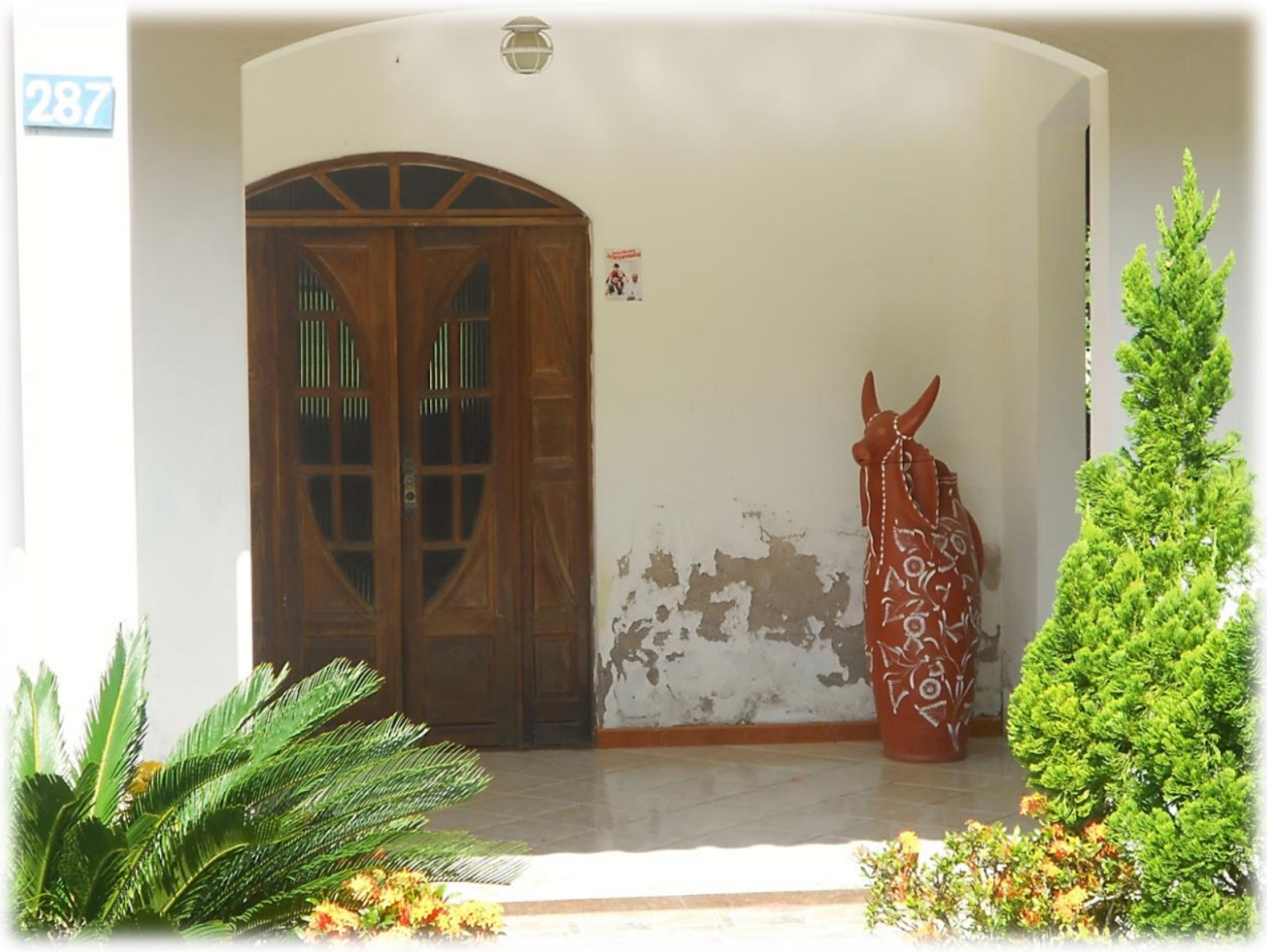

Boi-bilha feito por Seu Zé na varanda de sua casa

O porco-cofre vem sendo produzido, há bastante tempo, em quase todas as olarias do vilarejo. Coimbra (1980) faz menção ao porco-cofre já na década de 80. 
Em nossas conversas, o oleiro Nené afirmou mais de uma vez: "hoje o porco virou febre".

Os porcos são também classificados pelo tamanho, há uma vasta nomenclatura para qualificá-los, que vai desde o ratinho, ao porco pequeno, porco médio, porco intermediário, porcão até chegar ao porco gigante. O porco-cofre ou mealheiro se transformou em um emblema da cerâmica de Maragogipinho, sua produção atende a uma demanda grande de compradores locais e de turistas.

O fenômeno porco merece consideração. Ao lado dos objetos tradicionais, o porco vem se consolidando como mais um deles, inegavelmente. Por que o porco sobrevive com tanta força no mercado? É bem provável que não seja tanto pela sua função, que também vem se tornando obsoleta. No entanto, ouvi falar que alguns turistas ainda mantêm o hábito de poupar em porcos de barro comprados em Maragogipinho. A produção intensa de porcos me intrigou.

Investiguei as origens e descobri que o primeiro a criar um porco-cofre em Maragogipinho fora o oleiro Almerentino de Souza. Há cerca de 50 anos, foi procurado por uma professora que the encomendou porquinhos para ensinar os alunos a poupar. 
Numa reportagem para o Programa Globo Repórter, em 2013, Almerentino fala que nunca tinha feito um porco-cofre, mas arriscou e deu certo.

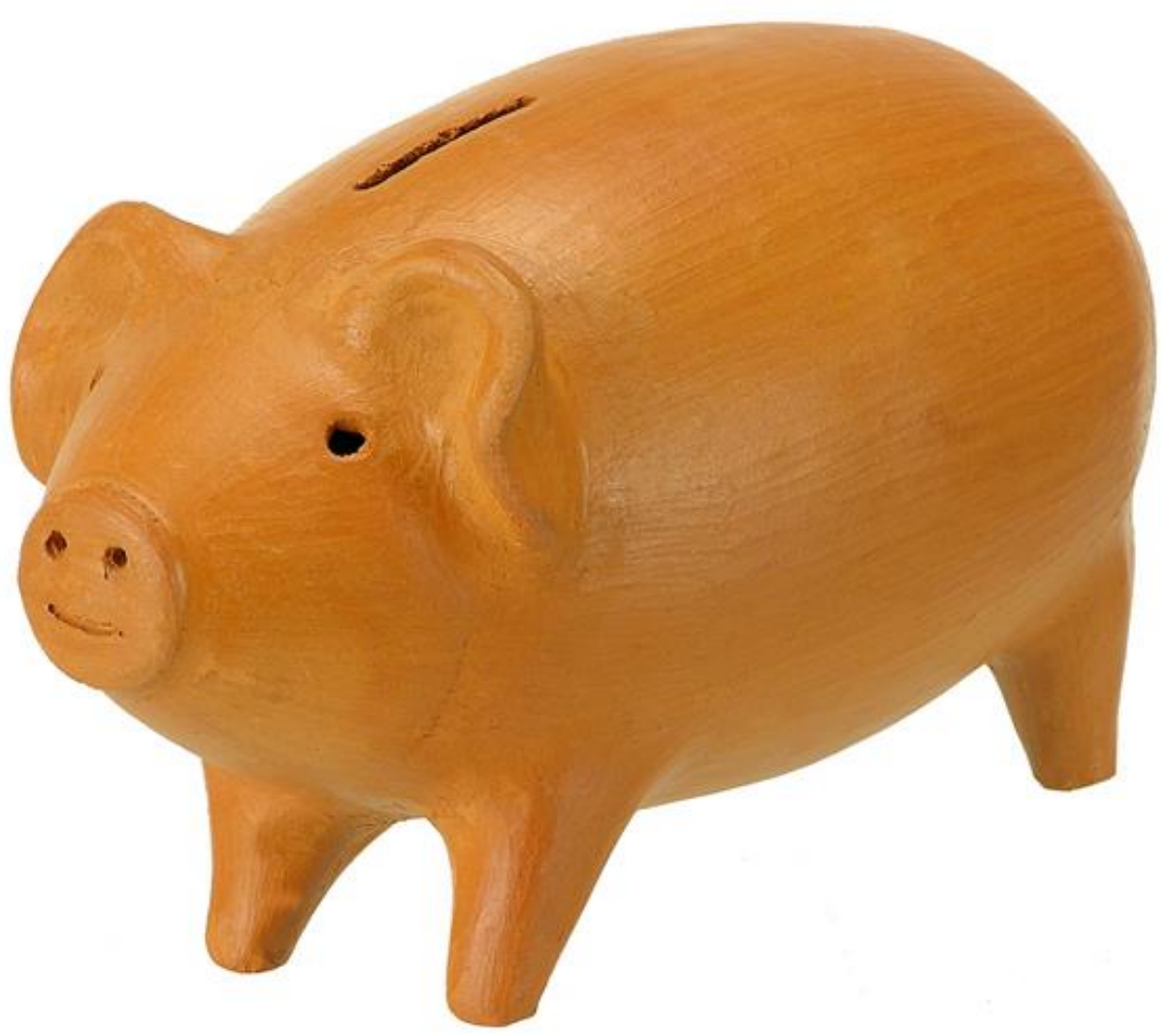

Porco-cofre 
Nené me disse que hoje em dia existe muita competição entre quem faz porco. Como não vi porcos em sua olaria, perguntei-Ihe por que não os fazia:

Eu fiz a conta e vi que não dava lucro, me dava era prejuízo.

Então, ele justificou descrevendo minuciosamente o quanto gastaria para fazer um porco e como a sua venda não compensava. Além do mais, não poderia subir o preço porque muita gente ali faz e vende barato.

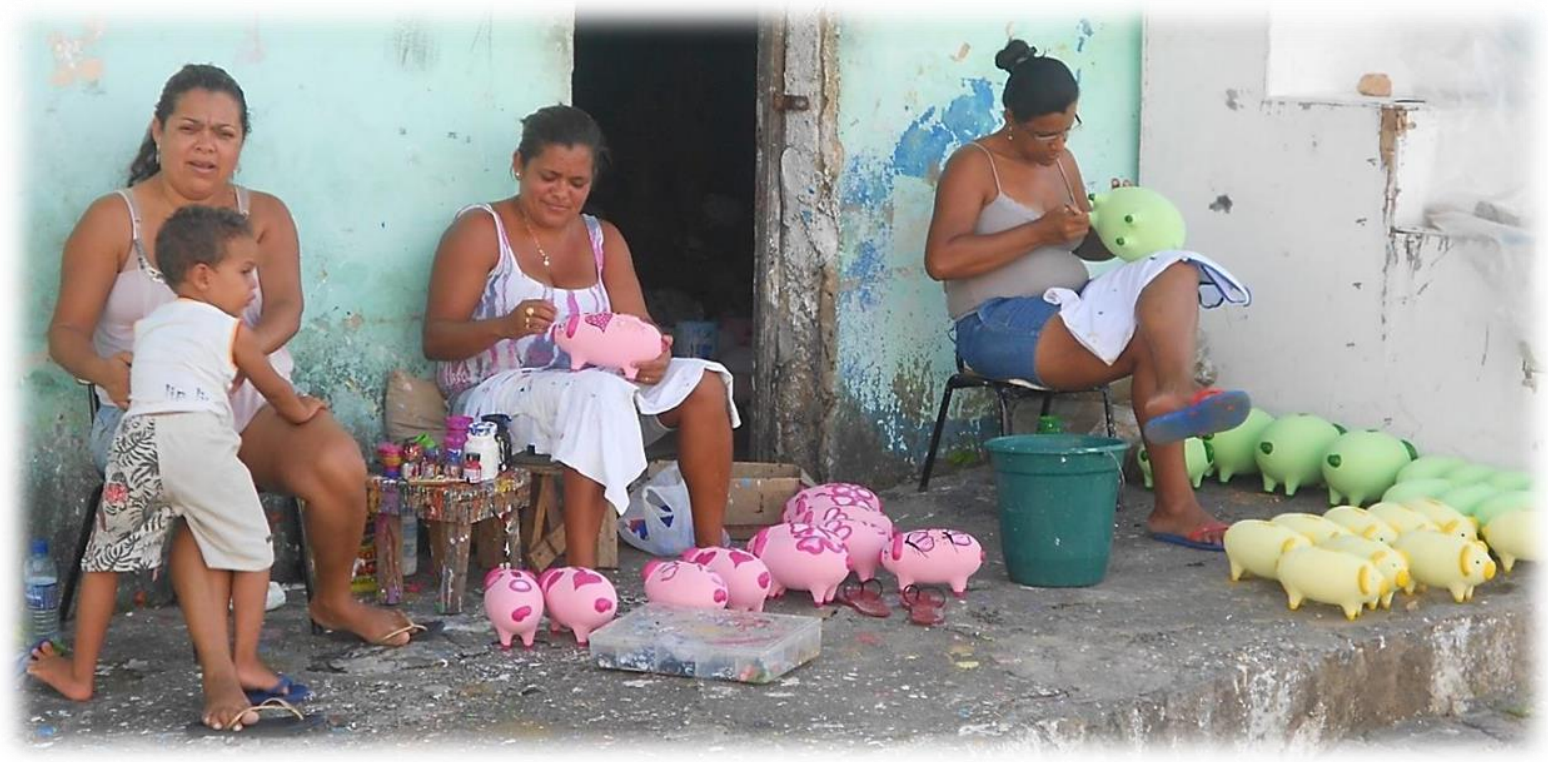

Mulheres pintando porcos-cofres com tinta acrílica 
Nesse sentido, a produção de objetos artesanais experimenta mudanças constantes para satisfazer a um público anônimo que os compra para guardar como recordação do lugar onde foram criados. O mercado, de uma hora para a outra, se inunda dessas peças que barateiam o trabalho do artesão.

As peças do artesanato testemunham as transformações pelas quais as culturas passam, a exclusão e inclusão de significados que se perdem ou se incorporam, inaugurando uma nova tradição. Para Lima (2010), os objetos artesanais são atemporais e as novas formas que surgem de tempos em tempos não implicam o menosprezo, nem a substituição daquelas já consagradas. "A elas se somam. E desta composição resulta o crescimento socioeconômico do grupo e a certeza da continuidade do saber que está contido e se expressa nesses objetos" (p. 34).

Eu acreditava que o fato de Nené não produzir porcos era por opção estética. Ledo engano. Foi assim que mudei meu ponto de vista sobre a produção de porcos. Entendi que o porco é um objeto artesanal que imprime identidade àquela comunidade. Se ele mobiliza, por um lado, a competição entre os artesãos, por outro, promove um elo que os une porque os representa. O porco é patrimônio cultural de Maragogipinho. 


\subsection{Caxixis}

Os caxixis são pequenos objetos, miniaturas da louça que se produz em Maragogipinho. Assim como o porco-cofre, o boi-bilha, a baiana-moringa, os caxixis constituem uma marca identitária da comunidade, podem ser vistos geralmente dentro de cestos de palha ou tachos de barro nas olarias, lojinhas e nos carrinhos de mão circulando pelas ruas.

Essas pecinhas lúdicas têm sua origem na tradição oleira de Portugal, provavelmente em Bisalhães, Niza e Estremoz. "São verdadeiros mimos de graça", enuncia Lucena (apud Pereira, 1957a, p. 78), "tão pequenos e tão lindos que talvez Ihe pudéssemos chamar a infância da louça de barro porque os seus modelos extremamente diminutos reproduzem toda a escala da louça grande".

A confecç̧ão de caxixis originalmente é relacionada ao processo de aprendizagem das crianças. Os meninos confeccionam caxixis para treinar o torno e as meninas ensaiam a pintura nesses pequenos objetos. Os caxixis consagram o aprendizado lúdico, imprimem relevo social às crianças, que são os verdadeiros iniciados. 
Essas miniaturas deram nome à tradicional Feira de Caxixis, em Nazaré das Farinhas. A Feira de Caxixis é muito antiga. Na opinião de alguns, existe há mais de duzentos anos, ocorre toda semana santa, de quinta-feira a domingo. Caxixis são fartamente expostos na feira em balaios, caixas, ou mesmo espalhados pelo chão.

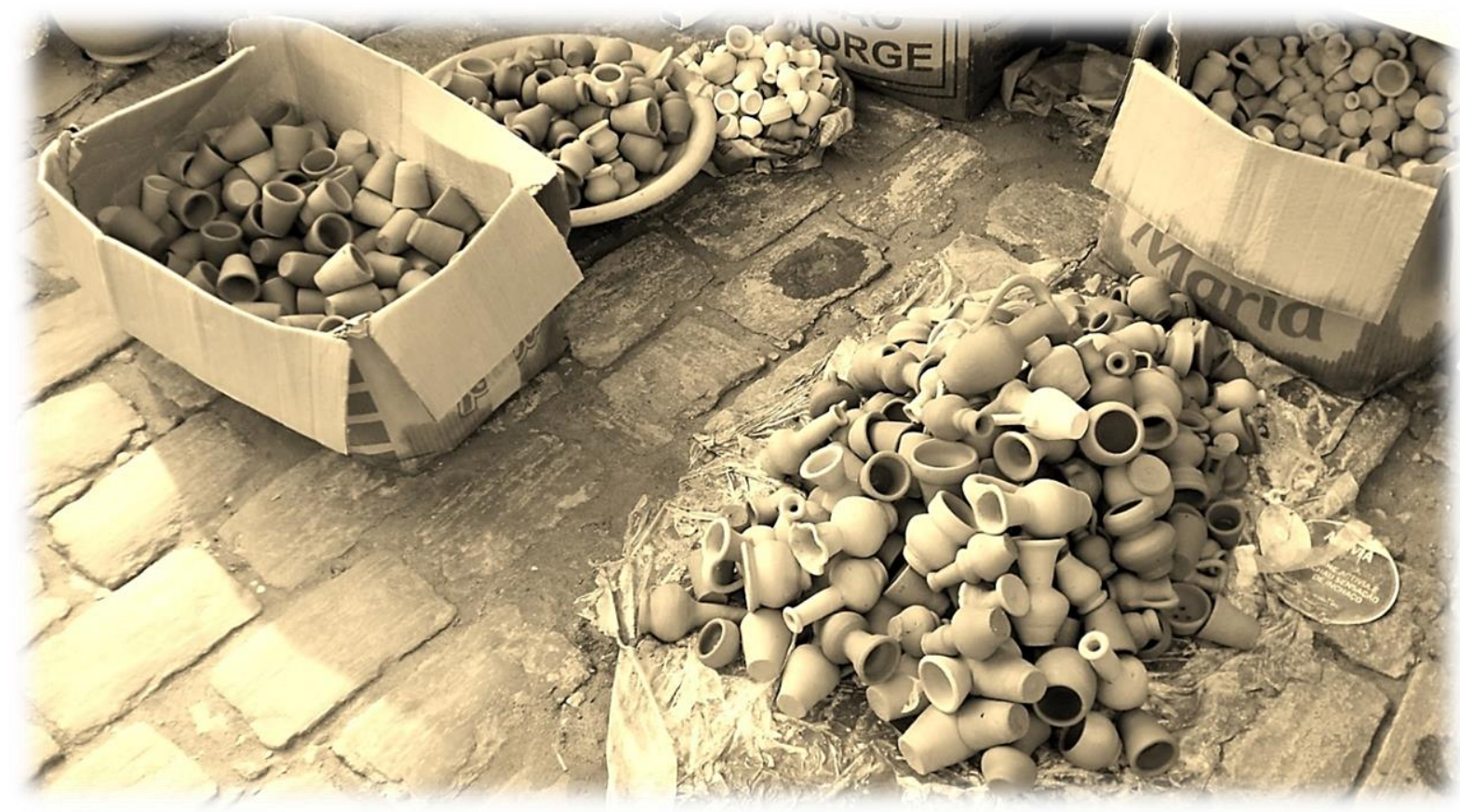

Caxixis na Feira de Caxixis

A primeira vez que visitei Maragogipinho era semana santa e pude conhecer a Feira de Caxixis. Na verdade, escolhi esse período no calendário para tomar 
contato com a produção de cerâmica a partir da feira. Sabia que os artesãos e artesãs de Maragogipinho produziam suas peças com bastante antecedência para a Feira dos Caxixis e depositavam nela boa parte das suas expectativas de venda para o ano.

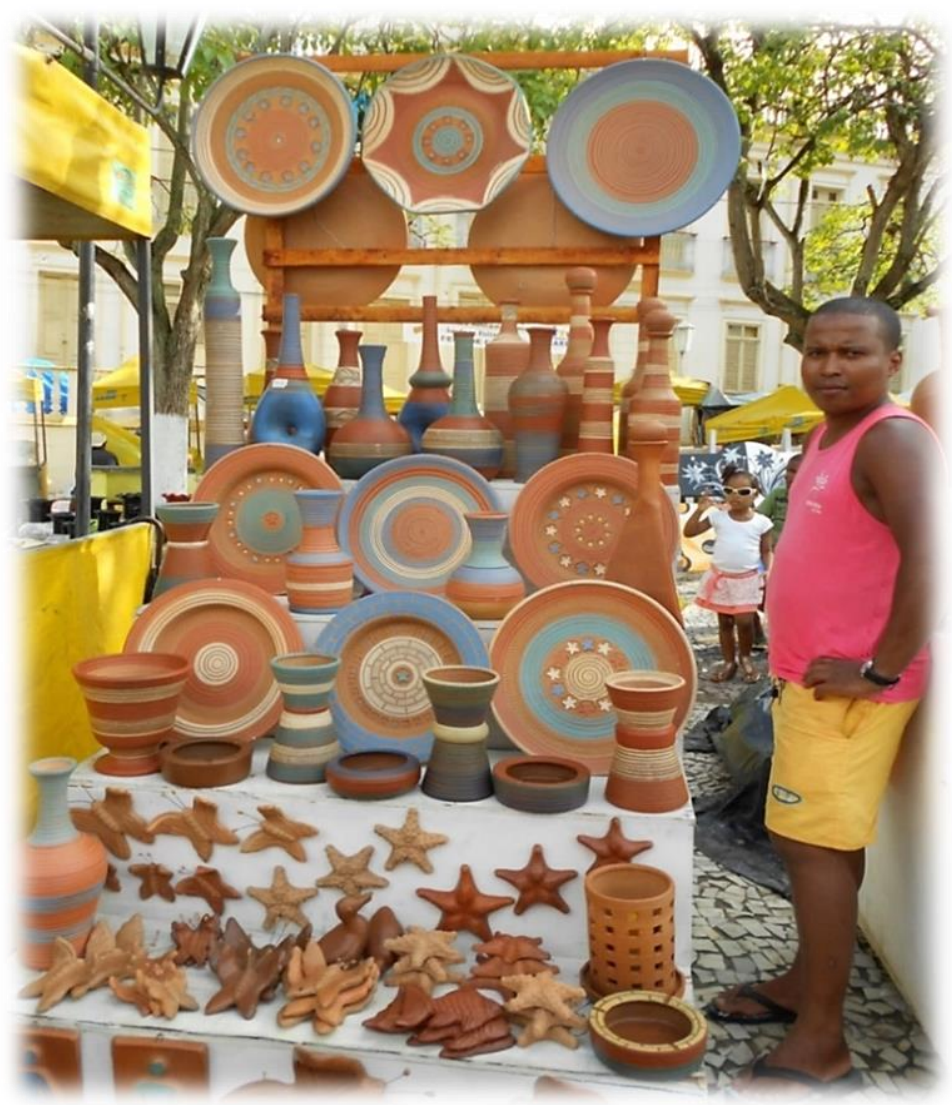

Sebinho, artesão de Maragogipinho na Feira de Caxixis 
Ao visitar a Feira, percorri as barracas com calma, conheci a cerâmica de vários artesãos e artesãs e reconheci a de outros tantos, com quem já havia travado contato. A feira mobiliza bastante gente entre artesãos, comerciantes e compradores. A pacata cidade de Nazaré fica cheia e barulhenta, a música nos alto-falantes ressoa em cada esquina.

Nelinho, Seu Zé e outros com quem conversei fazem duras críticas à Feira dos Caxixis, principalmente no que se refere à falta de subvenção e cuidado do poder público e a competição desenfreada, o que desvaloriza consideravelmente as peças. As barracas são precárias e grande parte dos objetos fica exposta no chão. Senti, realmente, um clima de ansiedade e competição entre os que vendiam.

Em 1957, Pereira já comentava que a Feira vinha decaindo:

Falam-nos com um certo regozijo porque ela é a festa deles [os artesãos]; mas não deixam de exprimir um certo descontentamento, uma espécie de desilusão... Tudo anda muito difícil - o barro está caro e à medida que o preço aumenta, o tamanho das pélas diminui. Não dá para quase nada. O preço do produto não permite que eles façam as obras suntuosas de antigamente. A prefeitura de Nazaré cobra-lhes uma taxa pelo pouco espaço que ocupam na praça durante os três dias, e 
aumentou-a agora. Por isso a feira vem decaindo e já não é como nos velhos tempos. Há oleiros que perderam o interesse e não se fazem representar. (...) O importante, entretanto, é que ainda existe e, apesar de decadente, deixa-nos a impressão de que viverá por longo tempo, com possibilidades até de se renovar e engrandecer, desde que a compreensão dos poderes públicos estimule e oriente a disposição popular (Pereira, 1957a, p. 89-90).

Certamente, a Feira dos Caxixis tornou-se maior se comparada à da década de 50 . Quanto aos antigos problemas, não se pode dizer que foram resolvidos.

\subsection{Beleza e utilidade}

Jarra de vidro, cesta de vime, 'huipil' de algodão barato, caçarola de madeira: objetos bonitos não a despeito de, mas graças a sua utilidade. Sua beleza é inseparável de sua função: são bonitos porque são úteis. Os objetos artesanais pertencem a um mundo anterior à separação entre o útil e o belo 
A afirmação de Paz de que o objeto artesanal pertence a um mundo anterior à separação entre utilidade e beleza instiga uma reflexão mais acurada. A beleza é um conceito bastante amplo e discutível, que assumiu diversas faces segundo a época e o lugar. A beleza encontrada nos artefatos nasce do uso cotidiano do objeto, feito para ser olhado e tocado com intimidade, diz Yanagi (1972). O autor refere-se a uma qualidade especial de beleza que concerne aos objetos artesanais:

A qualidade especial da beleza nos artesanatos é que consiste numa beleza da intimidade. Desde que os artefatos foram feitos para habitarem as casas cotidianamente, esta qualidade de intimidade é uma condição natural. Semelhante beleza estabelece um mundo de graça e sentimento. (...) As pessoas penduram suas pinturas no alto das paredes, mas colocam seus objetos de uso cotidiano perto de si e os acolhem em suas mãos (Idem, p. 198).

Sócrates foi um dos primeiros filósofos a relacionar a beleza à utilidade, seu fundamento estava na subordinação da forma à função. A beleza era, para ele, a expressão do bem em geral: o bem nos objetos é a sua utilidade e o bem no homem é a sua virtude. $O$ belo é a qualidade que atribuímos aos objetos que nos aprazem subjetivamente, mas esses objetos agradam porque nos são 
objetivamente úteis. Desse modo, o filósofo instala a beleza na esfera do útil: o objeto belo é aquele apropriado à realização de um fim.

Nos “Memoráveis", Sócrates explica a ligação entre o belo, o bom e o útil:

Pensas que uma coisa é o bom, outra o belo? Não sabes que tudo o que por uma razão é belo, pela mesma razão é bom! A virtude não é boa em uma ocasião e bela em outra. Assim também se diz dos homens serem bons e belos pelos mesmos motivos: o que no corpo humano constitui a beleza aparente constitui também a bondade. Enfim, tudo o que aos homens for útil será belo e bom relativamente ao uso que disso puder fazer-se.

Como? Então é belo um cesto de lixo? Pergunta Aristipo.

Sim, por Júpiter! E feio um escudo de ouro, já que um foi convenientemente feito para o seu uso e o outro não.

Dizes, pois, poderem os mesmos objetos ser belos e feios?

Como não! E podem também ser bons e maus: muitas vezes o que é bom para a fome, para a febre é mau, o que para a febre é bom é mau para a fome; o que é belo para a corrida não o é para a luta, o que para a luta é belo não o é para a corrida. Em suma, as coisas são belas e boas para o uso a que se destinam. Feias e más para usos a que não convenham (Xenofonte, apud Puls, 2006, p. 66). 
Com Sócrates, emerge uma estética fundada no uso, a beleza encontra-se nas necessidades primárias da humanidade, já que o filósofo considera belo um cesto de lixo, mas não um escudo de ouro. Puls explica que ao vincular beleza e utilidade, Sócrates elimina a distinção entre trabalho artístico e trabalho comum (idem, p. 72).

Os laços entre o belo e o bom, a estreiteza entre a estética e a ética, impregnaram a filosofia grega. Assim como Sócrates, Platão acreditava que havia interdependência entre o belo, o bom e o verdadeiro, que deveriam estar sempre conectados um ao outro. O bem é o que atribui verdade aos objetos cognoscíveis, o bem outorga ao homem o poder de conhecê-los, é o que confere luz e beleza às coisas. A beleza, ao produzir prazer, afeta nossa harmonia interior em direção à retidão, à boa conduta.

Nas sociedades ocidentais clássicas como a dos gregos e a dos egípcios, cita Andrade (1975), a produção de artefatos não se voltava apenas para um ideal de beleza, mas para uma beleza ideal porque a sensação de beleza não emanava apenas das linhas, dos volumes, dos claros-escuros, mas emergia, sobretudo, de exigências espirituais do indivíduo e de sua finalidade. Era um ideal necessário à coletividade. $\mathrm{O}$ autor cita os estudos do egiptologista Máspero que demonstraram 
que o princípio que regeu os mais de quarenta séculos da arte egípcia não se relaciona de forma alguma com a obtenção da beleza, mas com a eternidade, com a pesquisa do não perecível. Como articula Paz, na epígrafe deste capítulo: a utilidade esposou a beleza durante muito tempo, especialmente nos objetos adstritos a interesses religiosos e para atender a necessidades ligadas ao trabalho, à vida doméstica ou à diversão.

Nas culturas orientais, o sentido da beleza é também experiencial, liga-se ao uso. No Japão, os ceramistas contemporâneos conservam valores ancestrais no modo como se relacionam com as suas peças, dedicam a elas o mesmo tratamento que aos seres humanos, tanto na produção quanto no uso. Dessa forma, o objeto cumpre um trajeto de aprimoramento em que a beleza se funde com a utilidade.

Yanagi (1972) acreditava que a beleza dos objetos funcionais de uso diário tinha uma dimensão espiritual, budista, não dual. Para ele, contrários como belo/feio, perfeito/imperfeito, artesanato/arte, artesão/artista coexistem no mundo e, lamentavelmente, foram separados pelo tecnicismo.

Quando estudamos a cerâmica da dinastia Yi [Coréia, 1392-1910], descobrimos que sua beleza não é o que é alcançado através da eliminação da feiura, mas sim aquilo que eclode antes mesmo que a 
dualidade ocorra ao homem. A cerâmica não é o resultado de um conhecimento da natureza da beleza, mas é produzida antes que haja qualquer questão sobre entendimento ou não entendimento. Para aplicar à cerâmica, portanto, os critérios de beleza e fealdade, habilidade e inabilidade não fazem sentido (Idem, p. 142).

O objeto artesanal é considerado por Yanagi como ético e belo, feito por um autor anônimo sem obsessão consciente pela beleza e que, amorosamente, repete gestos incansáveis liberando, através da experiência e destreza, a sua força estética. Nakano $(1989$, p. 30) comenta que o ceramista dispensa ao seu pote os cuidados de uma mãe gerando um filho. Mais tarde, aquele que dele fizer uso o moldará através do convívio.

Otávio Paz (1991) enxerga com agudeza poética a relação orgânica que estabelecemos com os objetos artesanais:

Vasilha de barro cozido: não a coloques na vitrina dos objetos raros. Faria mau papel. Sua beleza está aliada ao líquido que contém e à sede que sacia. Sua beleza é corporal; vejo-a, toco-a, cheiro-a, ouço-a. Se está vazia, é preciso enchê-la; se está cheia, é preciso esvaziá-la. Tomo-a pela alça torneada, como a uma mulher pelo braço; levanto-a, inclino-a sobre 
uma bacia em que derramo o leite ou pulque - líquidos lunares que abrem e fecham as portas do amanhecer e do anoitecer, do despertar e do dormir. Não é um objeto para contemplar, mas para dar de beber (Idem, p. 45).

A peça artesanal naturalmente solicita de nós uma acolhida tátil, ela sobrevive e se realiza no contato humano, em um contínuo acalanto entre utilidade beleza.

$\mathrm{O}$ artesanato não nos conquista somente por sua utilidade. Vive em cumplicidade com os nossos sentidos, e daí ser tão difícil desprendernos dele. É como jogar um amigo na rua (Idem, p. 50).

Muitos dos objetos que vemos atualmente nos museus, prossegue Paz (1991), têm sua origem em uma época em que a beleza não era um valor isolado e autônomo. Nesses locais, as peças se apresentam fora de seu contexto original, intocáveis, se oferecem ao público como divindades enigmáticas que exigem adoração (p. 46). Aos olhos do poeta, os objetos artesanais são feitos para cumprirem o seu próprio tempo:

$\mathrm{O}$ artesanato corre junto com o tempo, e não quer vencê-lo. (...) O artesanato não quer durar milênios nem está possuído pela pressa de 
morrer logo. Transcorre com os dias, flui conosco, desgasta-se pouco a pouco, não busca a morte nem a nega: aceita-a. Entre o tempo sem tempo do museu e o tempo acelerado da técnica, o artesanato é a palpitação do tempo humano. É um objeto útil, mas também belo; um objeto que dura, mas que acaba e se resigna a acabar; um objeto que não é único, como a obra de arte, e que se pode substituir por outro objeto parecido mas não idêntico. O artesanato nos ensina a morrer e, assim, nos ensina a viver (Idem, p. 57).

\subsection{Anonimato}

O anonimato da peça artesanal marca ambivalências também no campo das identidades: o objeto geralmente não recebe uma assinatura ou firma do artesão ou artesã, ele representa em si mesmo, em sua corporeidade, o autor e a sua linhagem. Nos objetos artesanais, a própria comunidade reconhece o criador e seus ancestrais: as gerações de autores que partilharam estilos e modos de fazêlo. Paz lembra que, por mais que não contenham uma assinatura formal, esses objetos guardam as impressões digitais de quem os fez, seja concreta ou metaforicamente: 
Essas impressões são a 'assinatura' do artista, não um nome; nem uma marca. São antes um sinal: a cicatriz quase apagada que comemora a fraternidade original dos homens (Paz, 1991, p. 51).

No antigo Egito, aponta Andrade (1975), a impessoalidade dos artefatos constituía uma marca. O temperamento pessoal do autor não se manifestava senão por detalhes de feitura quase imperceptíveis e quem, por acaso, observar superficialmente a arte egípcia nada mais perceberá que não a noção de impessoalidade coletiva.

A virtude dos objetos artesanais está em que não se sente nenhuma imposição de personalidade neles, afirma Yanagi (1972, p. 200). O objeto brilha, não o seu autor. É no anonimato que as profundas raízes do grande artesão encontram sua sustentação.

Em Maragogipinho, os artesãos e artesãs não precisam assinar as peças para serem reconhecidos socialmente, nem se preocupam com isso, não manifestam necessidade de firmar sua autoria. Aos que perguntei sobre o assunto, me responderam que só de olhar a peça, já se sabe quem a torneou e quem a pintou. A rede de relações viva e compartilhada que mantêm lhes possibilita uma autenticação autoral que não se expressa numa assinatura, ou em um carimbo. 
Vamos ouvir o que disse o oleiro Zé Curu quando questionado sobre se assina ou carimba suas peças:

Eu já não estou vencendo, quanto mais carimbando... O cara conhece só no olho: "olha o trabalho de fulano aí!". Eu não acho importante assinar (...), o que é seu é seu, ninguém tira.

O sentimento de pertença não necessita de firma. Zé Curu continua:

Eu aprendi com um rapaz chamado Eduardo. O que ele fazia, eu faço. Aí, quando a filha dele falou: "o mesmo trabalho de meu pai", eu achei bonito. Se eles não aprenderem [referindo-se ao filho que estava trabalhando na olaria], quando eu partir, isto daí não vai ficar na história.

Alguns oleiros de Maragogipinho receberam orientações externas a respeito da importância de firmarem seus nomes nas peças e aderiram a esta prática. 0 curioso é ver que algumas assinaturas não ganharam pompa nenhuma, apenas constituem os apelidos literais de seus autores, a forma como são conhecidos na comunidade, como a de Seu Zé. 
A controvérsia sobre se as peças devem ou não ser assinadas tem a ver com a questão dos direitos autorais e os direitos da coletividade, afinal esses conhecimentos e modos de fazer constituem os patrimônios culturais dos povos. No Brasil, não há uma legislação específica para o artesanato. Lima (2010, p. 48) acha que devemos colocar em pauta, com urgência, os direitos patrimoniais, em defesa das comunidades e de seus patrimônios imateriais.

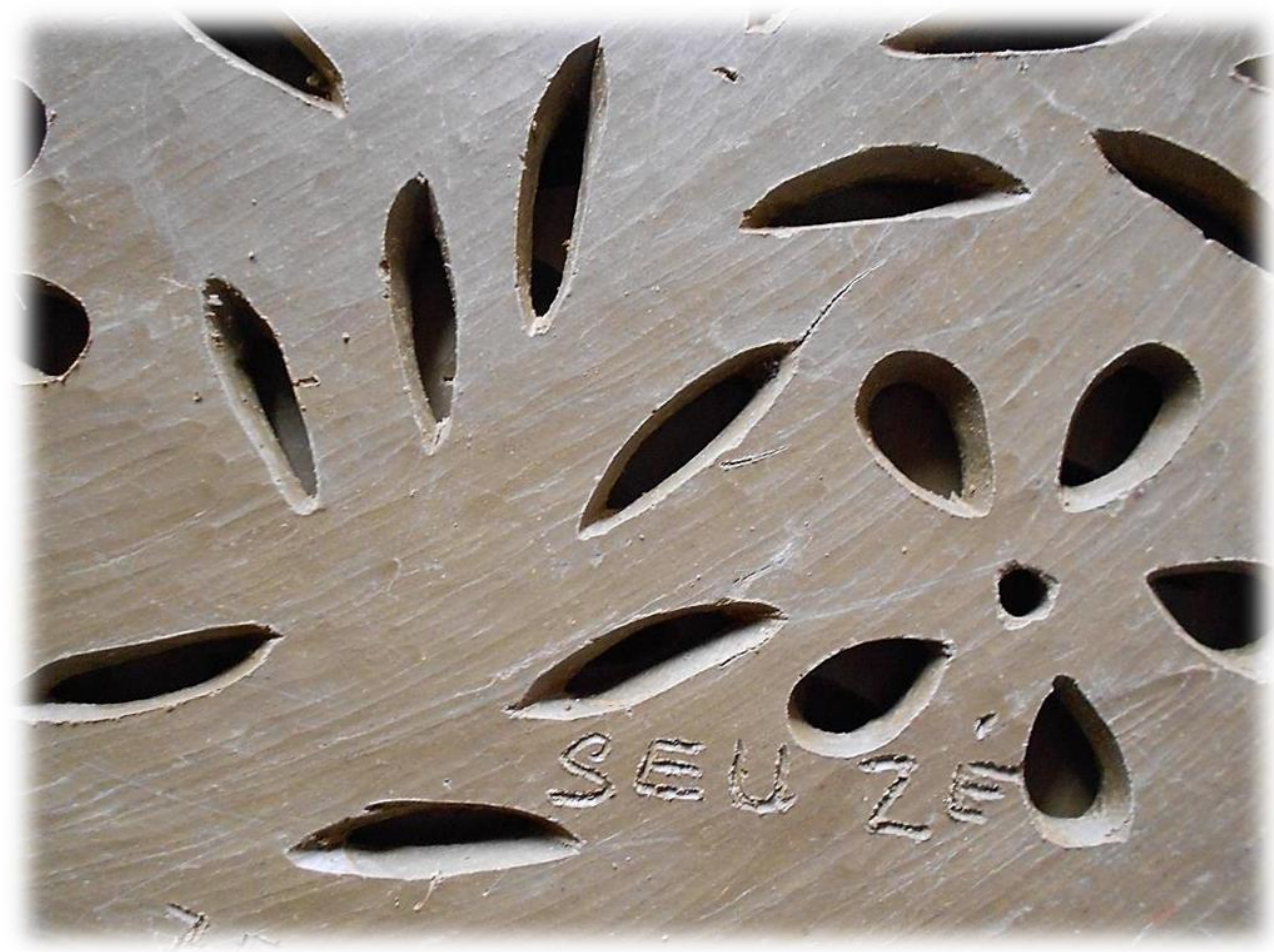

Detalhe de uma peça de Seu Zé 
175

(...) não se pode mais trabalhar a olho nem a palmo, por apalpação ou farejando, segundo os atrasados procedimentos tecnológicos de Cipriano Algor, que acaba de comunicar à filha com o ar mais natural do mundo.

A pasta está boa, úmida e plástica no ponto, fácil de trabalhar, ora, perguntamos nós, como ele poderá estar tão seguro do que diz se só lhe pôs a palma da mão em cima, se só apertou e moveu um pouco de pasta entre o dedo polegar e os dedos indicador e médio, como se, de olhos fechados, todo entregue ao sentido interrogador do tato, estivesse a apreciar, não uma mistura homogênea de argila vermelha, caulino, sílica e água, mas o urdume e a trama de uma seda. O mais provável, (...) é saberem-no os seus dedos, e não ele. Saramago, 2000, p. 148. 


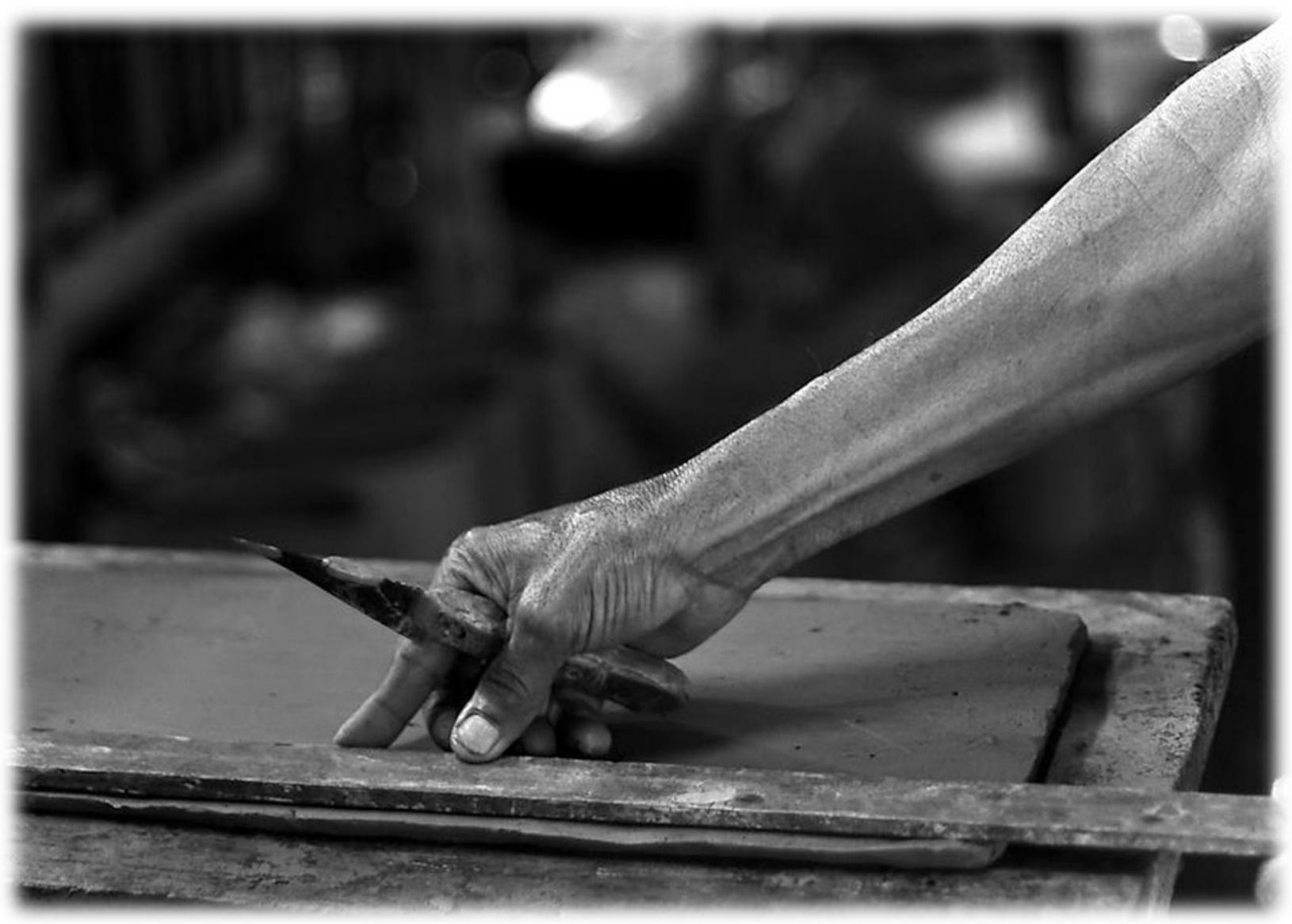

Artesão cortando uma placa de argila

(https://farm5.staticflickr.com/4057/4519222772_e48c335ebc_o.jpg) 


\title{
V. CADÊNCIAS: CORPO E CORPOREIDADE NO FAZER
}

\author{
ARTESANAL \\ El conocimiento y las habilidades \\ de las sociedades tradicionales \\ residen directamente en los sentidos y en los músculos, \\ en las manos que conocen, \\ que son inteligentes y que están directamente \\ alojadas y codificadas en los escenarios \\ y en las situaciones de la vida.
}

Juhani Pallasmaa

Nas culturas tradicionais, o mundo vital é construído inteiramente na experiência. Os conhecimentos do cotidiano possuem uma concretude, originam-se nas práticas sociais, no trabalho e nas atividades diárias. Constituem saberes da pele, dos ossos e músculos, dos cinco sentidos, das mãos, dos pés, da mente. Enfatizamos aqui a experiência do corpo como campo criador de sentidos, isto porque essa sabedoria não advém da ação exclusiva do intelecto, mas ocorre como um acontecimento da corporeidade e, assim, da existência. No movimento dos corpos podemos fazer a leitura, com lentes sensíveis, dos aspectos visíveis e invisíveis do ser humano, do conhecimento e da cultura. 
Os saberes corpóreos dos povos constituem seus patrimônios culturais imateriais, muitos deles preservados pela transmissão oral. Na América Latina e no Brasil, os conhecimentos assentados na vida, nos ofícios manuais e na oralidade ainda permanecem pouco valorizados. Os grupos culturais detentores dos diversos tipos de saberes - formados por não letrados e artistas que não circulam no meio acadêmico - historicamente vêm sendo tratados como primitivos. As suas práticas sociais, quando valorizadas, recebem um matiz folclórico de exotismo ou de tempo passado, remetem a uma ancestralidade que certamente reconecta as nações com as suas raízes, mas que não as atualiza. As culturas tradicionais são frequentemente consideradas como antigas e subalternas quando comparadas à modernização cultural que se impõe como meta para as sociedades latinoamericanas.

A instituição escola, por sua vez, não legitima os saberes não letrados e empreende amplas diligências no sentido de "substituir" esses conhecimentos advindos da vida, das práticas sociais e do trabalho. Os saberes aprendidos no cotidiano são desvalorizados no mundo urbano porque sua lógica fundada no realconcreto se contrapõe à lógica racionalista do conhecimento valorizado na escola, que tem na escrita a linguagem oficial e o meio de dominação e controle. 
A escrita é uma coisa, e o saber, outra. A escrita é fotográfica, mas não o saber em si. O saber é uma luz que existe no homem. A herança de tudo aquilo que nossos ancestrais vieram a conhecer e que se encontra latente em tudo o que nos transmitiram, assim como o baobá já existe em potencial em sua semente (Tierno Bokar, apud Hampáte Bâ, 1982, p. $1)$.

Há outras formas de expressar e conhecer o mundo que não somente pela linguagem escrita. É importante assinalar que esses saberes tradicionais são conhecimentos legítimos e válidos por si mesmos, não precisam ser suplantados, o seu valor sobrevém de um manancial ancestral que se atualiza constantemente e que demanda, com urgência, o reconhecimento da sua historicidade e importância cultural.

Como já foi dito, o desprestígio de uma sabedoria do corpo provém da estrita separação entre trabalho intelectual e trabalho manual, da cisão entre corpo e mente que se encontra fortemente cimentada na história do pensamento ocidental. No planeta globalizado, industrial, mecanizado, materialista e consumista, a vida cotidiana urbana, os processos de amadurecimento e educação, bem como o trabalho, se distanciam cada vez mais do mundo natural, do contato com os materiais, das intermitências do clima, dos fenômenos 
mutantes da natureza e do próprio corpo. Contudo, não é o que ocorre em Maragogipinho:

Nosso trabalho aqui é todo manual. A gente não tem aquela tecnologia, é um trabalho todo braçal, é um trabalho pesado, desde a preparação da argila bruta. A gente prepara a argila primeiro pisando com o pé, depois amassando com a mão. (...). O pessoal aqui não precisa de academia para ficar musculoso, este trabalho depende muito do corpo, o corpo precisa estar bem (Nelinho).

No século XXI, inúmeros povos dependem exclusivamente do corpo para executar o trabalho produtivo e da palavra falada (ou silenciada) para compartilhar conhecimentos. Os corpos das pessoas que trabalham com o barro são moldados pelas ações repetitivas, pela exposição ao sol e às intempéries, pelo contato direto com a natureza. Inúmeros labores são executados em grupo, de forma solidária, ritualizados por cadências, marcados em canções ou motes.

Em Maragogipinho, o barro desempenha uma função estruturante nas pessoas. Ele atua como extensão do próprio corpo, organiza o tempo, articula a sociabilidade, dá lastro para a vida familiar. O bailado dos pés e das mãos no torno, a cadência do corpo na pisa do barro, o tônus dos braços no amassamento 
constituem movimentos corporais extremamente expressivos, estéticos, que imprimem dignidade e beleza a quem os executa.

"Os ofícios tradicionais são os grandes vetores da tradição oral", diz Hampáte Bâ (1982, p. 11). O autor enfatiza que os próprios gestos dos artesãos são considerados uma linguagem nas sociedades tradicionais, que a gestualidade de cada ofício reproduz simbolicamente o mistério da criação primeira.

\subsection{O corpo-sujeito de Merleau-Ponty}

A corporeidade é a base de nossa relação com o outro e com o meio, é o substrato de nossas experiências. O ser humano está corporalmente inserido no mundo, ou seja, suas relações sociais, com a cultura e com a natureza são mediadas primordialmente pelo corpo. "O corpo é o sujeito da percepção", anuncia Merleau-Ponty (1999, p. 407), o corpo é nosso modo próprio de ser-no-mundo: não tenho um corpo, mas sou meu corpo. O corpo não é a morada do sujeito, não é algo de que possamos nos despir, nos desvencilhar.

Na filosofia cartesiana, a dualidade entre o sujeito e as coisas no mundo anula a relação originária entre o eu e o mundo, a experienciação efetiva do mundo. A 
filosofia merleau-pontyana se apoia na relação corpo-mundo: o corpo se realiza enquanto tal a partir de sua espacialidade e do desdobramento de seu ser no mundo.

Tudo o que sei do mundo, mesmo devido à ciência, o sei a partir de minha visão pessoal ou de uma experiência do mundo sem a qual os símbolos da ciência nada significariam. Todo o universo da ciência é construído sobre o mundo vivido, e se quisermos pensar na própria ciência com rigor, apreciar exatamente o seu sentido, e seu alcance, convém despertarmos primeiramente esta experiência do mundo da qual ela é expressão segunda (Merleau-Ponty, 1999, p. 6-7).

As coisas existem no mundo para mim que sou sujeito, na intrínseca relação que possuo com elas antes mesmo de se instalarem em meu pensamento, elas surgem para mim no momento em que eu as percebo pelos sentidos do meu corpo. 0 corpo-sujeito de Merleau-Ponty (1999) suscita a trama essencial entre o corpo e o mundo pré-reflexivo. O conhecer acerca do mundo surge de um corpo que percebe, que não é um pensante apenas, que não é a extensão das coisas e nem mesmo uma coisa entre as coisas. Mediador da relação entre o sujeito e o mundo, o corpo unido à consciência torna-se uma consciência corporificada, fundada na experiência sensorial do sujeito. 
Ser corpo no mundo é ser um corpo-próprio que ganha sentido por estar no mundo e ser totalmente apreendido por ele. "Nosso corpo não está primeiramente no espaço: ele é no espaço" (Idem, p. 205). Assim, o filósofo apresenta uma concepção que considera o corpo não como objeto para um "eu penso", mas como um conjunto de significações vividas que caminha para seu equilíbrio. A cada percepção enriquecemos o corpo-próprio, a nossa entidade sensorial.

No ato da percepção, os sentidos se comunicam no interior do corpo, articulados a um sistema sinestésico. O olhar não só vê, mas ouve, toca, cheira e saboreia. Nossos sentidos, portanto, não constituem meros receptores de estímulos. Já o mundo, com os movimentos de reciprocidade e reversibilidade, se oferece aos sentidos englobando o ser. Corpo e mundo são um "campo de presença".

Merleau-Ponty (Idem, p. 262) compara o corpo a uma obra de arte: meu corpo se desdobra em seus sentidos, é um estilo dos gestos de minha mão que acaba por implicar um conjunto de movimentos. Todas as minhas percepções são ligadas por uma configuração corpórea que, como num quadro em que o campo de presença está na combinação das cores, nasce das relações entre o corpo visual e o corpo tátil, constituindo um conjunto que reúne braços e pernas, que vê e que toca. 0 corpo-próprio, o Leib, é no mundo uma interpretação de si mesmo que se 
desenvolve pelos seus gestos, através dos seus sentidos e por meio do acontecimento corporal.

No "O Olho e o Espírito", Merleau-Ponty (2004) reflete sobre as relações entre o corpo e a arte, tomando como exemplo especialmente a pintura. Para o autor, os gestos da mão que pinta transubstanciam para a tela um certo impacto do mundo sobre o pintor. É oferecendo seu corpo ao mundo que o artista transforma o mundo em arte. A metamorfose do mundo se faz através do pintor. A expressão criadora é resposta ao mundo, não é incondicional.

O conhecimento, depois de ser convertido em um ingrediente do corpo, pode ser esquecido. Concordo com Bachelard quando afirma que "é preciso que o saber vá acompanhado por um esquecimento equivalente ao saber ele mesmo. O nãosaber não é uma forma de ignorância, senão um difícil ato de superação do conhecimento. Somente a este preço, uma obra é, a cada instante, essa espécie de começo puro que faz de sua criação um exercício de liberdade" ( Bachelard apud Pallasmaa, 2012, p. 163). No ato da produção, o artesão se esquece da teoria, aciona um saber corporal que entra em sintonia com a sua subjetividade e a essência da cultura, constrói um universo que reconstitui a ele próprio como corpo-sujeito no mundo. 


\subsection{A sabedoria das mãos}

A palma da mão é uma prodigiosa floresta muscular.

A menor esperança de ação a faz estremecer.

Gaston Bachelard

Aristóteles se equivocou ao afirmar que os humanos tinham mãos porque eram inteligentes; Talvez Anágoras estivesse mais certo ao sustentar que os humanos eram inteligentes porque tinham mãos.

Marjorie O’Rourke Boyle

Luz e mãos moldaram a impossível fronteira entre oceano e ventre. Luz e mãos me consolaram da incurável solidão de ter nascido.

Mia Couto

Heidegger associa a mão diretamente com a capacidade humana de pensar, a mão capta a materialidade do pensamento e a converte em imagem concreta (Pallasmaa, 2012, p. 14). Por meio das mãos, o homem trava contato com a dureza do pensamento. 
Talvez seja a própria mão quem imagina, admite Bachelard aludindo aos sonhos da mão:

Se a poesia deve reanimar na alma as virtudes da criação, se deve nos ajudar a reviver, em toda a sua intensidade e em todas as suas funções, nossos sonhos naturais, precisamos compreender que a mão, assim como o olhar, tem seus devaneios e sua poesia (Bachelard, 2001, p.66).

Etimologicamente o termo poiein significa "fazer". Essa palavra está na raiz da palavra poesia (Sennett, 2008, p.34). Assim, os poetas aparecem também como artífices. 


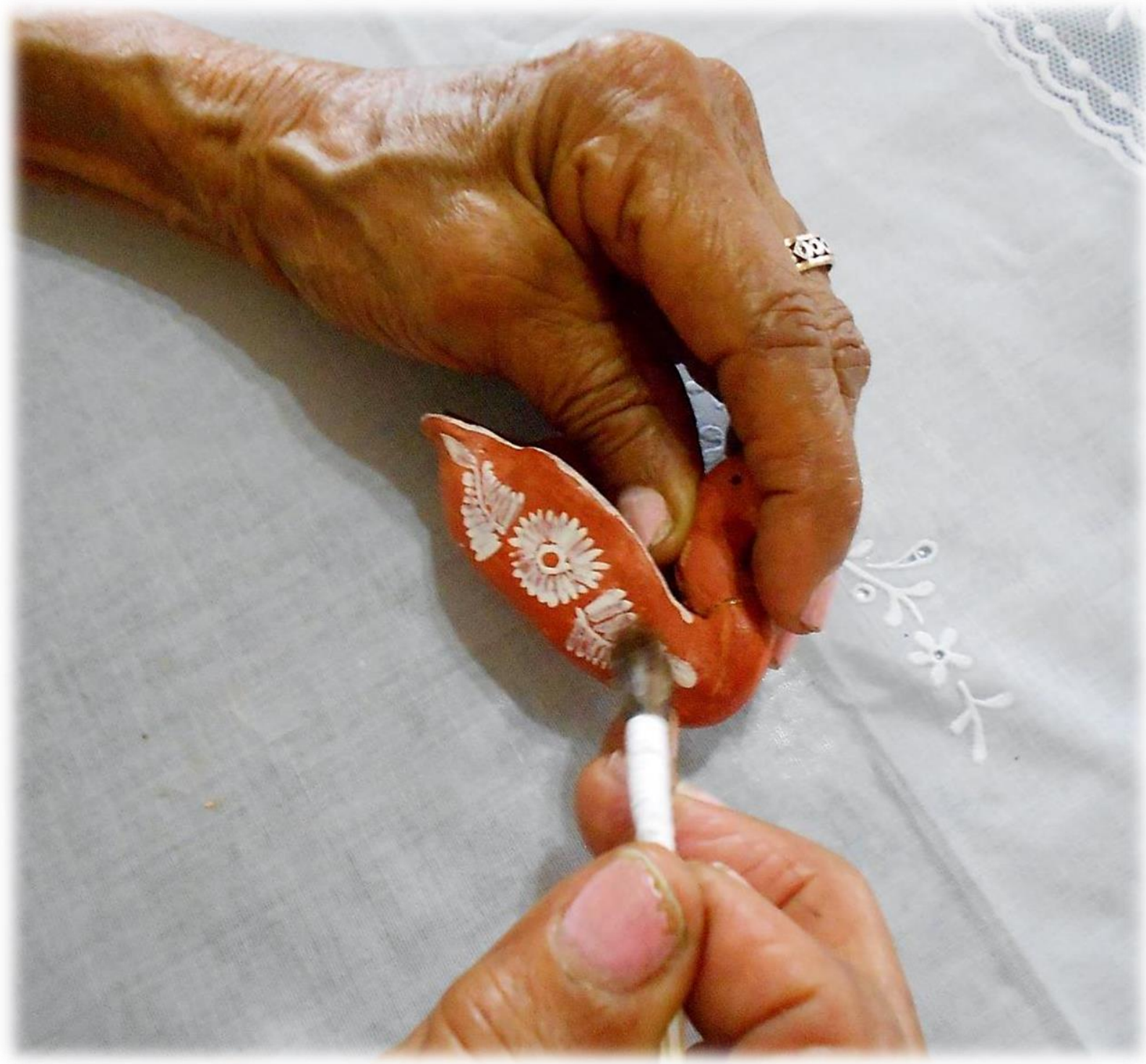

Mãos sonhadoras de Dona Santa, pintora de 87 anos 
Focillon (2012) considera o escritor Victor Hugo como o próprio artífice, um tipo de homem que faz uso das mãos para atacar a matéria e trabalhá-la. Ao citar "Trabalhadores do mar", descreve as mãos com que Victor Hugo teceu o romance:

Livro escrito com mãos de marinheiro, de carpinteiro e de ferreiro, que toma posse rudemente da forma do objeto e que o modela no mesmo ato de se moldar a ele (Idem, p. 28).

$\mathrm{Na}$ evolução da mão, a oposição entre o polegar e os demais dedos foi se tornando cada vez mais articulada. "Agarrar com força é anterior a agarrar com precisão" (Pallasmaa, 2009, p. 37).

O homem fez a mão, isto é, destacou-a pouco a pouco do mundo animal, libertou-a de uma antiga e natural servidão, mas a mão também fez o homem. Permitiu-Ihe certos contatos com o universo que os outros órgãos e partes do corpo não facultavam (Focillon, 2012, p. 9).

A mão ativa é capaz de se distender ou se encolher para alcançar, recolher e conter o objeto. Porém, não Ihe basta apenas apanhar, empunhar, agarrar, segurar ou largar, a mão deseja sempre mais, ela almeja transformar, trabalhar no que ainda não há. E, para saciar as mãos, o ser humano inventou a arte. 
A arte começa pela transmutação e continua pela metamorfose. A arte não é o vocabulário do homem falando ao Senhor, mas a renovação perpétua da Criação. É invenção de matérias, ao mesmo tempo que é invenção de formas. A arte constrói para si uma física e uma mineralogia. Mete as mãos nas entranhas das coisas para lhes dar a figura que lhe aprouver. É antes de tudo artesã e alquimista (Focillon, 2012, p. 18).

Comumente consideramos as mãos como membros triviais, apêndices que somente executam atividades ditadas pelo cérebro, esse sim dotado de funções superiores. No entanto, ao longo deste trabalho já demonstramos em diversos momentos que as mãos exercem uma preeminência sobre outros órgãos do nosso corpo e que, muito além de apenas perceber o mundo e executar tarefas, as mãos detêm conhecimentos, pensam, se emocionam, desejam, imaginam e sonham.

No campo mais concentrado, segura de si mesma e de seus movimentos, essa mão que sujeita às dimensões do microcosmo as enormidades do homem e do mundo é um prodígio por direito próprio. Não é uma máquina de reduzir. O que lhe importa é menos o rigor de uma medida estreita e mais a sua própria capacidade de ação e de verdade (Idem, p. 32). 
As mãos revelam a idade, a altura, o peso, a personalidade, o estado de espírito, a profissão de alguém. As impressões datilares garantem a identidade, na ponta dos dedos está representada toda a pessoa. São praticamente inexistentes os trabalhos humanos que não utilizam as mãos. A mão é a executora de labores.

Nos ofícios artesanais, o artesão dedica milhares de horas de sua existência concentradas nas mãos. Quanto mais bem feito for o trabalho, mais a mão do trabalhador está presente, a destreza das mãos funciona como referência para a qualidade da produção humana.

Teremos banido de nossas reflexões, como artesãos de habilidade em tudo maquinal, aquelas que, com uma paciência delicada e infalível, despertaram em matérias seletas e sob formas refinadas os sonhos mais concentrados? (Idem, p. 32).

Poetas, filósofos, pintores, escultores de todas as épocas e lugares reverenciam incessantemente as mãos humanas. Em um belo trecho de "A caverna", José Saramago desfia poeticamente a primazia das mãos sobre o cérebro:

(...) Na verdade, são poucos os que sabem da existência de um pequeno cérebro em cada um dos dedos da mão, algures entre a falange, a 
falanginha e a falangeta. Aquele outro órgão a que chamamos cérebro, esse com que viemos ao mundo, esse que transportamos dentro do crânio e que nos transporta a nós para que o transportemos a ele, nunca conseguiu produzir senão intenções vagas, gerais, difusas e, sobretudo, pouco variadas acerca do que as mãos e os dedos deverão fazer. Por exemplo, se ao cérebro da cabeça lhe ocorreu a ideia de uma pintura, ou música, ou escultura, ou literatura, ou boneco de barro, o que ele faz é manifestar o desejo e ficar depois à espera, a ver o que acontece. Só porque despachou uma ordem às mãos e aos dedos, crê, ou finge crer, que isso era tudo quanto se necessitava para que o trabalho, após umas quantas operações executadas pelas extremidades dos braços, aparecesse feito. Nunca teve a curiosidade de se perguntar por que razão o resultado final dessa manipulação, sempre complexa até nas suas mais simples expressões, se assemelha tão pouco ao que havia imaginado antes de dar instruções às mãos. Note-se que, ao nascermos, os dedos ainda não têm cérebros, vão-nos formando pouco a pouco com o passar do tempo e o auxílio do que os olhos veem. $\mathrm{O}$ auxílio dos olhos é importante, tanto quanto o auxílio daquilo que por eles é visto. Por isso o que os dedos sempre souberam fazer de melhor foi precisamente revelar o oculto. $O$ que no cérebro possa ser percebido como conhecimento infuso, mágico ou sobrenatural, seja o que for que signifiquem sobrenatural, mágico e infuso, foram os dedos e os seus 
pequenos cérebros que tho ensinaram. Para que o cérebro da cabeça soubesse o que era a pedra, foi preciso primeiro que os dedos a tocassem, Ihe sentissem a aspereza, o peso e a densidade, foi preciso que se ferissem nela. Só muito depois o cérebro compreendeu que daquele pedaço de rocha se poderia fazer uma coisa a que chamaria faca e uma coisa a que chamaria ídolo. O cérebro da cabeça andou toda a vida atrasado em relação às mãos, e mesmo nestes tempos, quando nos parece que passou à frente delas, ainda são os dedos que têm de the explicar as investigações do tacto, o estremecimento da epiderme ao tocar o barro, a dilaceração aguda do cinzel, a mordedura do ácido na chapa, a vibração sutil de uma folha de papel estendida, a orografia das texturas, o entramado das fibras, o abecedário em relevo do mundo. (...) Toda a arqueologia de materiais é uma arqueologia humana. $O$ que este barro esconde e mostra é o trânsito do ser no tempo e a sua passagem pelos espaços, os sinais dos dedos, as raspaduras das unhas, as cinzas e os tições das fogueiras apagadas, os ossos próprios e alheios, os caminhos que eternamente se bifurcam e se vão distanciando e perdendo uns dos outros. Este grão que aflora à superfície é uma memória, esta depressão a marca que ficou de um corpo deitado. $\mathrm{O}$ cérebro perguntou e pediu, e a mão respondeu e fez (Saramago, 2000, p. 82). 
A insinuação de Saramago de que são os cérebros das mãos e não o cérebro da cabeça quem dialoga com o material, no caso o barro, faz todo o sentido. Quando modelamos uma peça, cada pequena parte das nossas mãos conduz um movimento diferente sobre a argila originando uma orquestra de ações táteis que se sincronizam para estruturar o objeto.

\subsection{Relações fraternas mediadas pelo fazer artesanal}

Ser uma consciência, ou, antes, ser uma experiência, é comunicar interiormente com o mundo, com o corpo e com os outros, ser com eles em lugar de estar ao lado deles.

Merleau-Ponty

A força da alienação vem dessa fragilidade dos indivíduos que apenas conseguem identificar o que os separa e não o que os une.

Milton Santos

Em Maragogipinho, uma peça de cerâmica que passa por distintas mãos, é geralmente o resultado de afazeres comunitários dos corpos masculinos e femininos. O corpo de quem labuta com barro tem tônus, é forte, ágil. Por lá, ouvi 
várias vezes a mesma fala sobre os benefícios estéticos que o ofício traz para o corpo: "aqui a gente não precisa de academia, trabalhar com barro deixa qualquer um sarado". Neste pequeno vilarejo, vi corpos esculturais, dos quais emana naturalmente beleza física e vigor, como saldo do trabalho diário.

Nos meios urbanos, o culto a um corpo jovem e erotizado, bem como a uma mente inteligente e brilhante, refletem um modo cada vez mais autocentrado, narcisista e individualista de ser e estar no mundo. A noção cartesiana de sujeito universal resiste ainda na afirmação do indivíduo como ponto de vista sobre todos os outros pontos de vista, do sujeito que profere verdades fora do tempo e que reduz o outro a objeto: "Como então eu posso, eu que percebo e que, por isso mesmo, me afirmo como sujeito universal, perceber um outro que no mesmo instante me subtrai esta universalidade?" (Merleau-Ponty, 1999, p. 482).

Todo outro é um outro eu mesmo, afirma o filósofo. Só apreendo o outro através de uma analogia comigo mesmo. Percebemos outra sensibilidade e é a partir disso que percebemos outro pensamento. Nesse sentido, na experiência do mundo, a experiência do corpo consigo mesmo é atravessada pela experiência do outro corpo, instauradas em uma relação de intercorporeidade. 
Uma mão que posa no ombro ou na coxa de outro corpo, já não pertence de todo ao corpo de que procede (Rilke, apud Pallasmaa, 2012).

Se por exemplo, avisto uma paisagem ao lado de outra pessoa, através da intercorporeidade ela deixa de ser minha e torna-se uma paisagem que é nossa. Reconheço no mar que ele vê o mar que vejo e vice-versa, porque o meu mar passa em seu corpo e o mar dele no meu. "Eu e outrem comungamos sobre um mesmo panorama que vemos por dois pontos de vista diferentes. Vejo que ele vê. Reconheço que meu mundo sensível é também o dele, pois assisto à sua visão. Meu verde passa nele e o seu em mim" (Merleau-Ponty, 1999, p. 276). No entanto, a visão dele não é igual à minha, elas se penetram, mas são verdadeiramente distintas.

Merleau-Ponty apresenta-nos um mundo potencialmente solidário, nele nossa relação originária com o outro é visceral, nossos corpos e almas estão urdidos em um mesmo tecido. O termo solidariedade provém do latim solidus, que significa firme, inteiro, completo e salvus, que quer dizer seguro, salvo. Por meio da relação solidária mantemos a integridade de nossa humanidade, nos completamos e ficamos a salvo. 
Nas comunidades indígenas, nos povos rurais, nas favelas e na periferia das grandes cidades é comum subsistir o convívio solidário pautado na ajuda mútua como modo de amenizar as injustiças provocadas pelas situações de desigualdade, a cooperação como forma de resistência às adversidades econômicas e sociais. Nesses grupos, prevalecem as máximas de que a união faz a força, ninguém é tão autossuficiente que não precise da ajuda do outro.

As relações solidárias paradoxalmente dão substância às identidades individuais. Induzem a uma maior aceitação da diversidade, fazem reconhecer que somos distintos, mas que pertencemos a uma mesma matriz. Nos mitos cosmogônicos, há aspectos que se repetem em diferentes culturas, como a produção do primeiro homem a partir do barro. A cosmologia ioruba reforça o princípio da igualdade na diferença. Ferreira-Santos é quem conta a história:

Olorum encomenda a Ogum a continuação da criação dos homens, aos quais Ihes insufla vida. Ogum é o orixá senhor do ferro, da agricultura, da caça e da guerra, protetor de todos os que executam trabalhos manuais e com instrumentos de ferro. Recolhido o barro de Nanã, a grande mãe ancestral, senhora da água e da terra fecundadas, o ferreiro modela e cria o ser humano em seu forno, enquanto bebe aguardente. Um dos aspectos mais belos desta cosmovisão matriarcal é a inclusão da 
alteridade no seio do próprio mito de origem, como também ocorre com os mitos de matriz ameríndia. Enquanto bebe ao trabalhar Ogum, assim como todos os deuses trabalhadores, se confunde com o tempo de cozinhar os seres humanos em seu forno. Retira-os em momentos inadequados e, ao invés de desfazer-se deles, remete-os para outras regiões conforme a coloração do barro cozido: os mais brancos para o norte, os mais amarelos para a região da nascente, os mais vermelhos para a região do poente e aqueles em que acertou o ponto de cozimento, os frutos negros da criação, espalha-os pela terra-mãe África (Ferreira-Santos, 2008, p. 239).

Na cosmovisão ioruba, não se trata de excluir o outro nem de eliminá-lo, trata-se de conceber este outro como diverso, como faceta múltipla de uma mesma origem. Inúmeros mitos de povos de diferentes épocas e lugares fazem alusão ao barro como matéria-prima geradora do homem (idem, ibidem). Realmente, o barro é um material que suscita a criação, a peça de barro invita a relação com o outro, convoca à partilha. Nós a agasalhamos em nossas mãos, em nosso colo e a intercorporeidade se materializa no objeto.

A jarra de água ou de vinho no centro da mesa é um ponto de confluência, um pequeno sol que une os comensais. $\mathrm{O}$ artesanato é uma 
espécie de festa do objeto: transforma o utensílio em signo de participação (Paz, 1991, p.52).

Para Paz (1991), os objetos feitos pelas mãos expressam vida física compartilhada em sua constante oscilação entre beleza e utilidade, prazer e uso. Eles nos dão lições de sociabilidade. As mãos que amassam a massa experimentam, nas palavras de Bachelard (2001, p. 66), uma maleabilidade da plenitude, uma alegria que se espraia ao outro, companheiro de amassadura. 0 pancalismo ${ }^{7}$ da matéria oferece imagens que congregam as pessoas e exaltam valores humanos. Bachelard nos remete a uma bela passagem de Moby Dick, em que Melville descreve o amassamento do espermacete ${ }^{8}$ no barco:

Nossa função era esmagar aqueles grumos na mão para fazê-los voltar a ser líquidos. Um doce e untuoso trabalho. (...) Eu banhava as mãos e o coração naquela indescritível matéria. (...) Apertar! Apertar! Apertar! Passei a manhã inteira apertando o espermacete, tanto que no fim eu mesmo me fundi nele. Eu apertava até que uma estranha loucura se

\footnotetext{
${ }^{7}$ Pancalismo, na concepção de Bachelard, consiste na vontade de querer e de ver em tudo o belo.

${ }^{8}$ Substância oleosa, semelhante à cera, extraída da cabeça e da gordura que fica sob a pele do cachalote. $O$ espermacete é usado como ingrediente de certas pomadas e cremes para o rosto. Antigamente era usado na fabricação de velas. Nas fábricas, o espermacete é usado para lubrificar máquinas. Também é utilizado para amaciar o couro.
} 
apoderasse de mim. Surpreendi-me apertando sem querer as mãos de meus companheiros, tomando-as por suaves grumos. Essa ocupação fez um sentimento tão forte, tão afetuosamente amigável, tão terno que, finalmente, sem interrupção, eu apertava as mãos deles, olhando-os nos olhos com ternura como para lhes dizer: Ó bem-amados semelhantes, por que continuar alimentando as injustiças sociais e a nos demonstrar reciprocamente o menor mau humor ou ciúme. Vamos, apertemo-nos as mãos em roda; fundamo-nos universalmente uns nos outros até nos tornarmos um espermacete, um leite de beleza! (Melville, apud Bachelard, 2001, p. 67).

O amassamento do espermacete despertou o altruísmo entre as pessoas, no barco. Altruísmo é um vocábulo cunhado por Augusto Comte ${ }^{9}$ para caracterizar as disposições individuais e coletivas dos seres humanos a dedicarem-se aos outros. Uma pessoa altruísta age de modo a conciliar sua satisfação pessoal com o bem estar e a satisfação dos outros, de sua família e de sua comunidade. Os instintos de benevolência são tipicamente humanos. A expressão "dar uma mão" materializa o gesto de ajudar o outro e concretiza o sentido da solidariedade no trabalho das mãos.

\footnotetext{
9 A primeira vez que a palavra altruísmo apareceu foi no livro "Catecismo" de Augusto Comte, publicado em 1954.
} 
A cadeia produtiva que se criou no passado e que sobrevive até hoje entre os trabalhadores do barro, em Maragogipinho, favorece o altruísmo entre os artesãos. Mesmo ante as queixas de alguns de que atualmente a nova geração não quer saber do barro e os que vêm de fora desconhecem e desrespeitam aspectos tradicionais de manufatura dos produtos, o clima entre os oleiros mais antigos, em que as olarias se avizinham, é de solidariedade. Ainda dividem os fornos para a queima e muitos trabalham em família, como Zé Curu e Almerentino.

Outros trabalham sozinhos, já sem filhos para compartilhar o ofício, porém resistem bravamente como Padre que só produz ao modo tradicional, com o acabamento do tauá e da tabatinga. As peças confeccionadas desta maneira são imensamente mais trabalhosas.

Não tenho ajudante. Meu ajudante é Deus. Eu faço tudo, tudo do meu trabalho, tudo! Se precisar, eu contrato só o empelador. Burnir, se depender de burnição eu mesmo vou burnir (Padre).

Ainda que trabalhe solitariamente, Padre partilha o forno com outros dois artesãos. Nesse território mais antigo das olarias de Maragogipinho, em que passei vários dias, notei que os homens, além de parentes, mantêm uma parceria, 
todos se conhecem com certa intimidade e nenhum deles me falou mal do outro. Por vezes, nossa conversa era interrompida por algum comprador que entrava na olaria procurando determinado artefato ali inexistente. O oleiro prontamente recomendava o trabalho do compadre, isto aconteceu mais de uma vez.

A produção artesanal solicita que uns complementem o trabalho dos outros, como maneira de conservação da integridade do grupo social. As demandas materiais, simbólicas e afetivas dificilmente podem ser satisfeitas sem uma base em interesses comuns, em laços consanguíneos ou de companheirismo.

$\mathrm{O}$ artesanato tradicional roça o tempo todo a fronteira entre o eu e o outro. Ao criador, não cabe apenas dominar um material através da técnica e saber fazê-lo expressar-se. Seu ofício leva-o inevitavelmente a relacionar-se com o que outros criaram. Resulta quase incompreensível que um artesão possa trabalhar somente para expressar-se a si mesmo. Ele se relaciona sempre, consciente ou inconscientemente, ao que antes foi e ao está sendo feito por outros.

A arte é o social em nós, e se o seu efeito se processa em um indivíduo isolado, isto não significa, de maneira nenhuma, que as suas raízes e essência sejam individuais (Vygotsky, 2001, p. 315). 


\subsection{A cadeia produtiva da cerâmica de Maragogipinho}

No povoado, os laços de parentesco tecem as relações sociais e de trabalho. A cerâmica em Maragogipinho mantém características de produção basicamente familiar. A organização da família geralmente se articula em torno dos papéis que seus membros exercem no trabalho: o pai é o oleiro e a mãe a pintora, os filhos homens aprendem a olaria com $o$ pai e as filhas mulheres aprendem 0 acabamento e a pintura com a mãe. É no seio da família que as crianças observam, imitam, mexem no barro, brincam e trabalham, tudo ao mesmo tempo.

Os saberes da cerâmica demandam a sinergia do corpo inteiro, exigem concentração, paciência, tempo e, acima de tudo, dedicação. No século $X X I$, era da velocidade, estas são qualificações que estão se tornando cada vez mais raras entre nós.

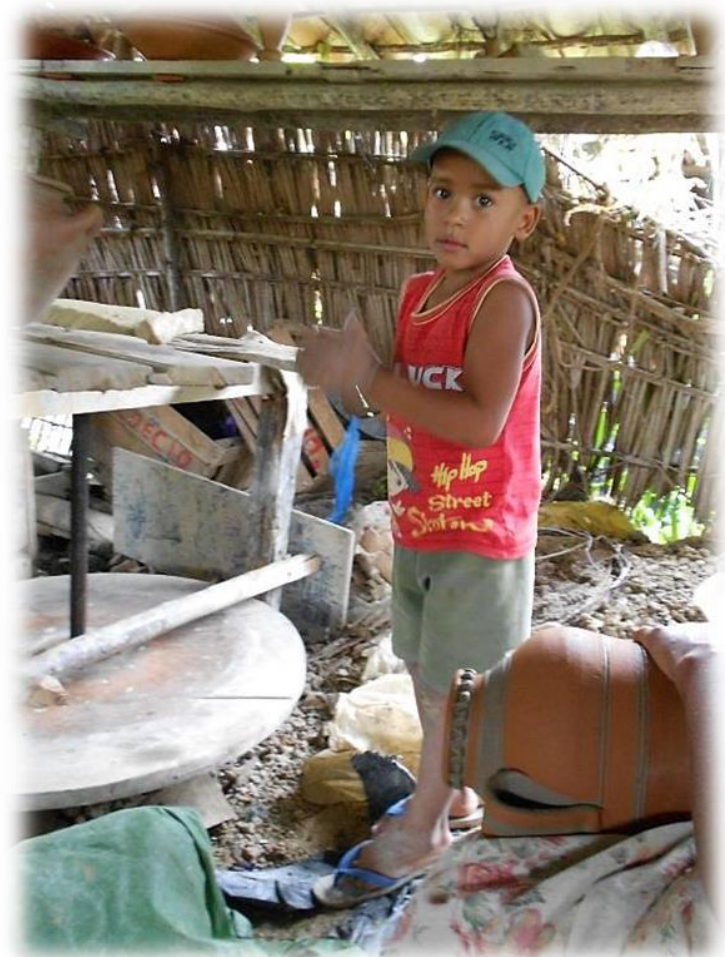

Menino brincando com o barro numa olaria 


\subsubsection{Divisão do trabalho entre homens e mulheres}

Em Maragogipinho, a divisão e a partilha do trabalho entre os homens e as mulheres são determinadas pela tradição. No decorrer dos anos, vêm ocorrendo mudanças significativas na estrutura social e econômica do trabalho com barro nessa comunidade. No que tange ao gênero nas relações de trabalho, constatei, por exemplo, que ainda hoje muito poucas mulheres vão para o torno ou fazem queimas, essas tarefas permanecem na alçada dos homens. Se, em tempos remotos os limites de cada atividade eram mais definidos, como a organização do trabalho vem ocorrendo atualmente?

Hoje está mais misturado, um está fazendo a coisa do outro. Mas antes era bem específico o que a mulher fazia e o que o homem fazia, nenhum entrava no departamento do outro. A mulher sempre foi, antes, pra brunir e pintar, certo? O homem sempre foi para produzir as peças, preparar a argila, a mão de obra braçal, lidar com a lenha, essas coisas, queimação de forno e tudo o mais. Hoje não. Hoje tem mulher que queima forno, hoje tem mulher que se arrisca até a querer ir ao torno, são poucas, mas tem. Hoje, se precisar, o homem dá polimento na peça dele, até pinta! Tem um rapaz aqui na frente que ele pinta (Nelinho). 
Descobri que há certo preconceito com relação às mulheres entrarem numa olaria, ou os homens pintarem a cerâmica, principalmente porque na divisão do trabalho repousam valores arraigados da sociedade de Maragogipinho:

Hoje ainda tem um pouco de preconceito. Ontem você viu, a minha irmã estava aqui. Na época de meu pai, ele não queria nenhuma mulher aqui. O trabalho da mulher tinha que ficar em casa. As peças iam até a mulher, eram os meninos que carregavam. De primeiro, aqui se carregava no balaio, naquele cesto de palha que colocava na cabeça e levava. O pessoal mesmo que trabalhava com essas peças grandes, como talha e porrão, tinha gente já específica para carregar. Depois que surgiu o carrinho de mão, todo mundo quer carregar no carrinho de mão. Agora não, agora as mulheres vêm fazer o trabalho na própria olaria. Ainda tem algumas para quem se leva em casa. Mas hoje, a própria mulher está vindo para a olaria. Eu mesmo fico aqui, aí as meninas resolvem tudo para mim, se tem uma encomenda elas vêm e pegam as peças (Nelinho).

Na sociedade patriarcal de Maragogipinho, a ocupação de espaços nitidamente masculinos ainda é considerada como transgressão feminina. Nem sempre tranquila, a presença das mulheres no ambiente das olarias abala costumes e regras construídas por leis consuetudinárias. 


\subsubsection{Extração do barro}

Do início ao fim, o trabalho com a cerâmica é corporal. O processo começa com a extração manual da argila nas fazendas próximas de Maragogipinho. A época para a extração obedece às leis da natureza e à tradição, deve ocorrer quando a lua está crescente ou minguante. Se retirado em dias de lua cheia ou nova, o barro fica 'envenenado', podendo influenciar negativamente na resistência da peça, tornando-a frágil e quebradiça (Moreira, 2010, p. 37-38).

Os locais de extração são chamados de barreiros, e os fornecedores de barreiristas. O barreirista indica o lugar onde será feita a escavação e, geralmente, são contratados um ou mais escavadores que extraem o barro com a ajuda de ferramentas simples, como pás e enxadas. 


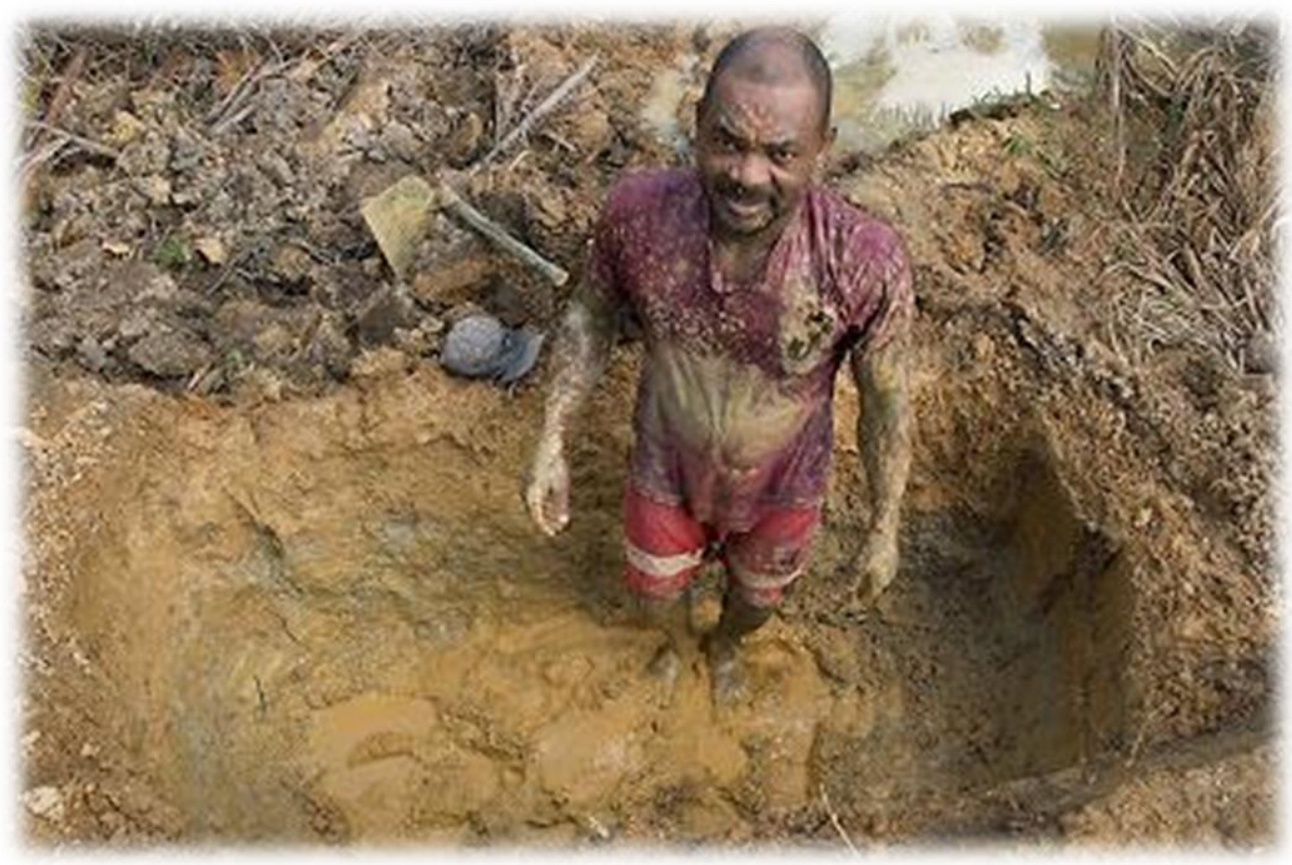

Sr. Natal extraindo barro

(Foto de Israel Kinslansky - http://kislansky.blogspot.com.br/)

O escavador cava até conseguir uma profundidade que permita a obtenção de um barro de boa consistência. Essa operação é realizada com a ajuda de uma vareta de madeira introduzida dentro do poço e quando retirada traz na extremidade uma amostra da qualidade do barro, esse instrumento é que dirige o trabalho do escavador e determina a profundidade do poço a ser explorado. Os oleiros vêm encontrando certa dificuldade em recrutar mão de obra para realizar a extração, 
pois o barro de boa qualidade está localizado em cavas fundas, que chegam a ter de cinco a oito metros, onde é necessário colocar estacas para evitar desmoronamentos. $O$ trabalho é perigoso para quem não tem experiência, muitos já sofreram acidentes. A escavação que dá origem ao poço de extração provoca algum tipo de degradação ambiental, dependendo da conformação do terreno e do tamanho dos poços.

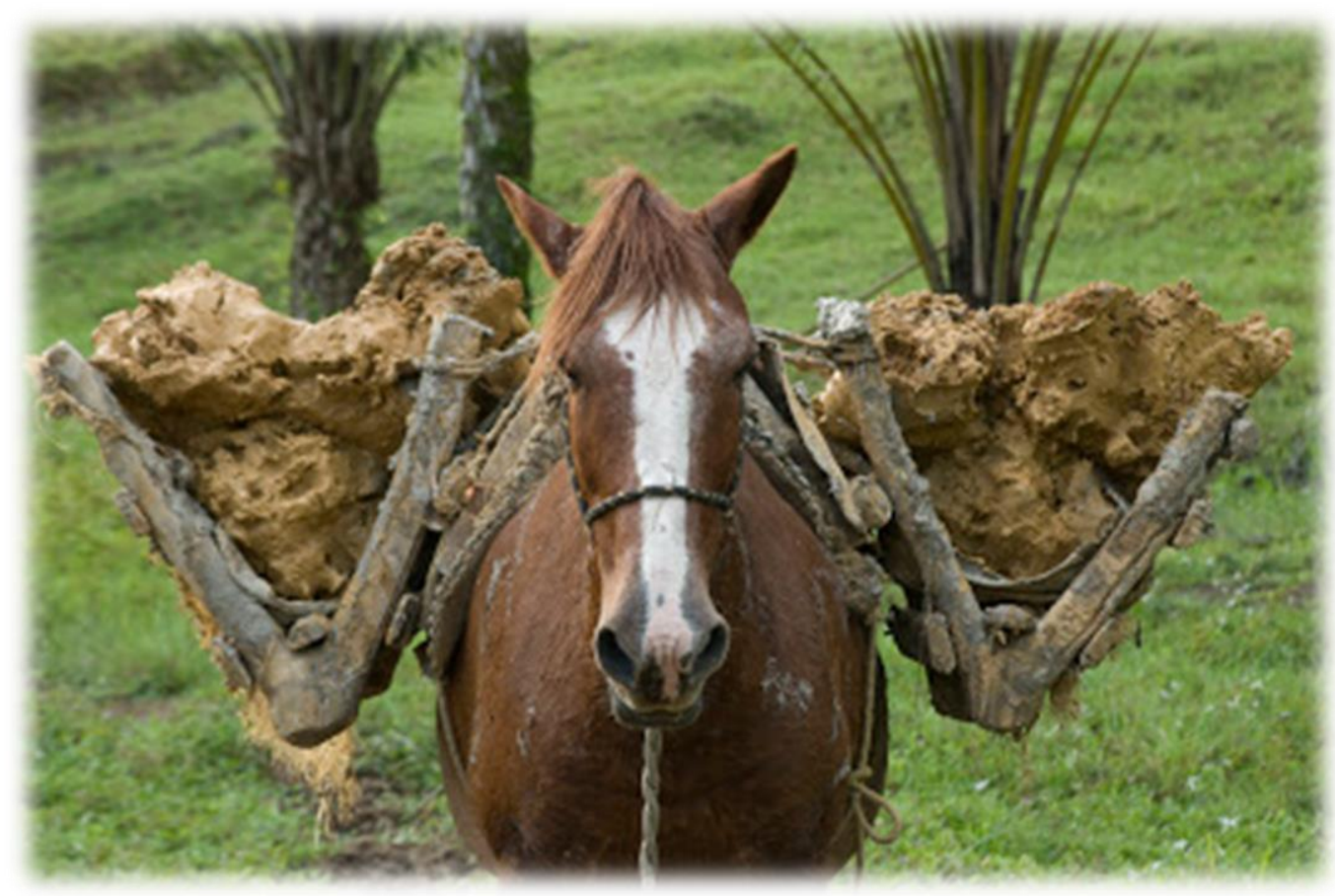

Transporte em animais de carga, que levam, em média $300 \mathrm{Kg}$ de barro

(Foto de Israel Kinslansky - http://kislansky.blogspot.com.br/) 
O oleiro Nené relata que na região há principalmente três tipos de barro: o barro branco, que quando queimado permanece branco, o amarelo que fica creme, e o caboclo que adquire um tom rosado. Quanto à consistência, existe o barro gordo e o barro magro: o gordo é liso, escorregadio, o magro contém muita areia, é "ariento", conforme Nené. O barro vai escurecendo conforme a profundidade do poço. O barro magro é claro, tirado em áreas superficiais. Os barros devem ser misturados de acordo com a peça que se quer fazer:

Este barro aqui é liso, este daqui é ariento. Tem que botar $\mathrm{x}$ deste mais $\mathrm{x}$ deste pra fazer a talhinha, pra ela sair boa. Se a senhora fizer com o este daqui [liso] puro, ela não vai prestar, com este [ariento] puro também não presta. Vai botar $10 \%, 20 \%, 30 \%, 50 \%$ dependendo da peça (Nené).

\subsubsection{Processamento do barro}

Atualmente, o transporte do barro até Maragogipinho é feito em caminhão, com capacidade para até quatro toneladas. Há pouco tempo, era transportado em pequenas embarcações. O barro chega dentro das olarias em carrinhos de mão, armazenado em um canto ou mesmo no centro, e molhado com frequência. 


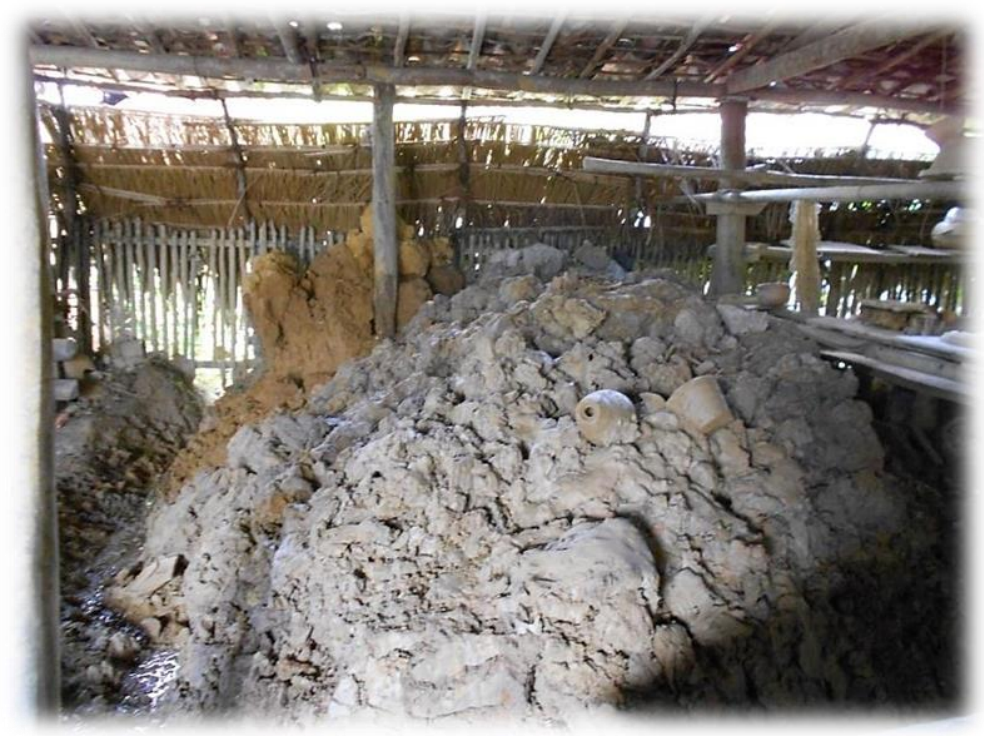

Depósito de barro dentro de uma olaria

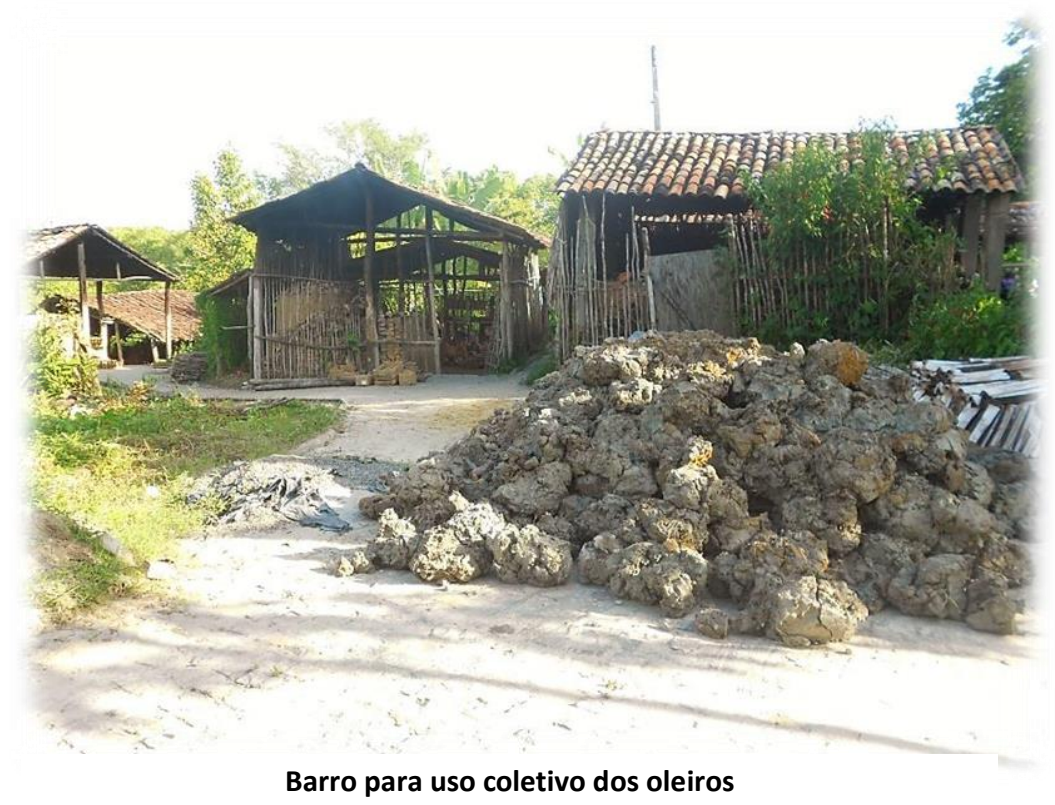




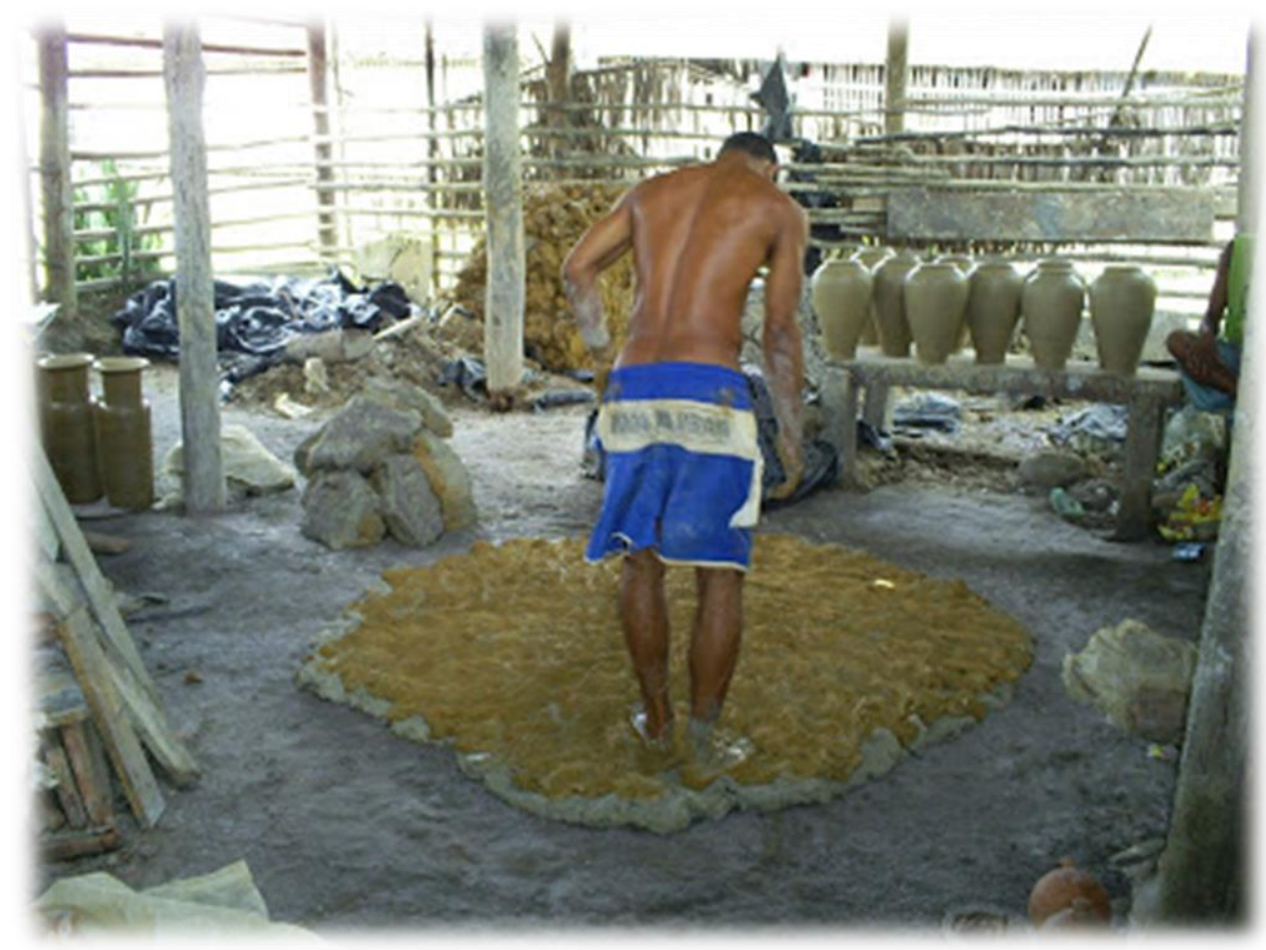

Pisa do barro

O processamento do barro se inicia com a pisa, executada pelo amassador, figura imprescindível na olaria. O local da pisa é dentro da própria olaria. O oleiro, após decidir o que vai produzir, determina a quantidade que será retirada para a atividade. $\mathrm{O}$ amassador forra o chão com uma camada de areia fina, coloca o barro úmido e, descalço, pisoteia-o durante longo tempo, numa espécie de dança sobre o barro. "A dança dos pés amansa o barro" (Maragogipinho, 1968). Nessa 
fase podem ser misturados alguns tipos de barro e são retiradas impurezas como raízes e pedras.

Os pés se movimentam em busca da massa ideal. Vívidos, inteligentes, perspicazes, esmagam a terra úmida auferindo sua densidade, uniformidade e resistência.

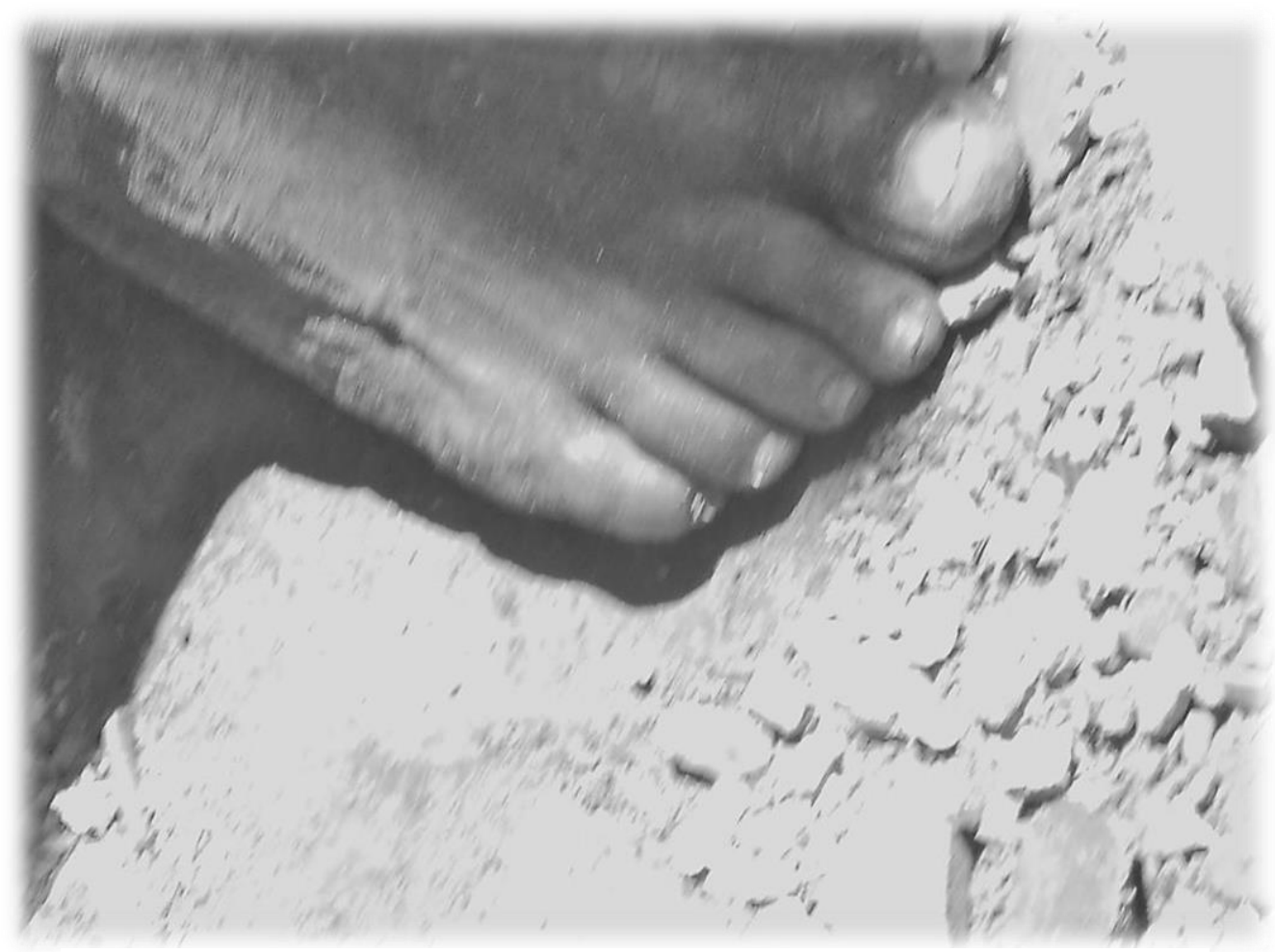

Pé do oleiro Nené 
Depois dos pés, inicia-se o profundo e poético trabalho das mãos.

\title{
5.4.4. Amassamento do barro
}

\author{
A esfera cotidiana do trabalho e da vida \\ significa uma transmissão infinita \\ das destrezas manuais e de seus produtos \\ a outras pessoas; \\ um mundo vital tradicional constitui um encontro \\ e uma união contínuos das mãos de gerações sucessivas.
}

Pallasmaa, 2009, p.55.

Após pisar, o amassador leva o barro para uma mesa baixa chamada de empelador, onde é amassado com as mãos. Nessa etapa, o amassador continua limpando o barro de impurezas, pedras e raízes que, se não retiradas, podem fazer com que a peça estoure no momento da queima, levando tudo a perder.

A construção de qualquer objeto requer sempre o amassamento do barro. Esse contato inicial já deflagra um primeiro embate da mão com a matéria. É no movimento de amassamento que exploramos minuciosamente a massa, apertando-a com vigor expulsando qualquer bolha de ar ou grumo que esteja impedindo a sua uniformidade, a sua integridade. 


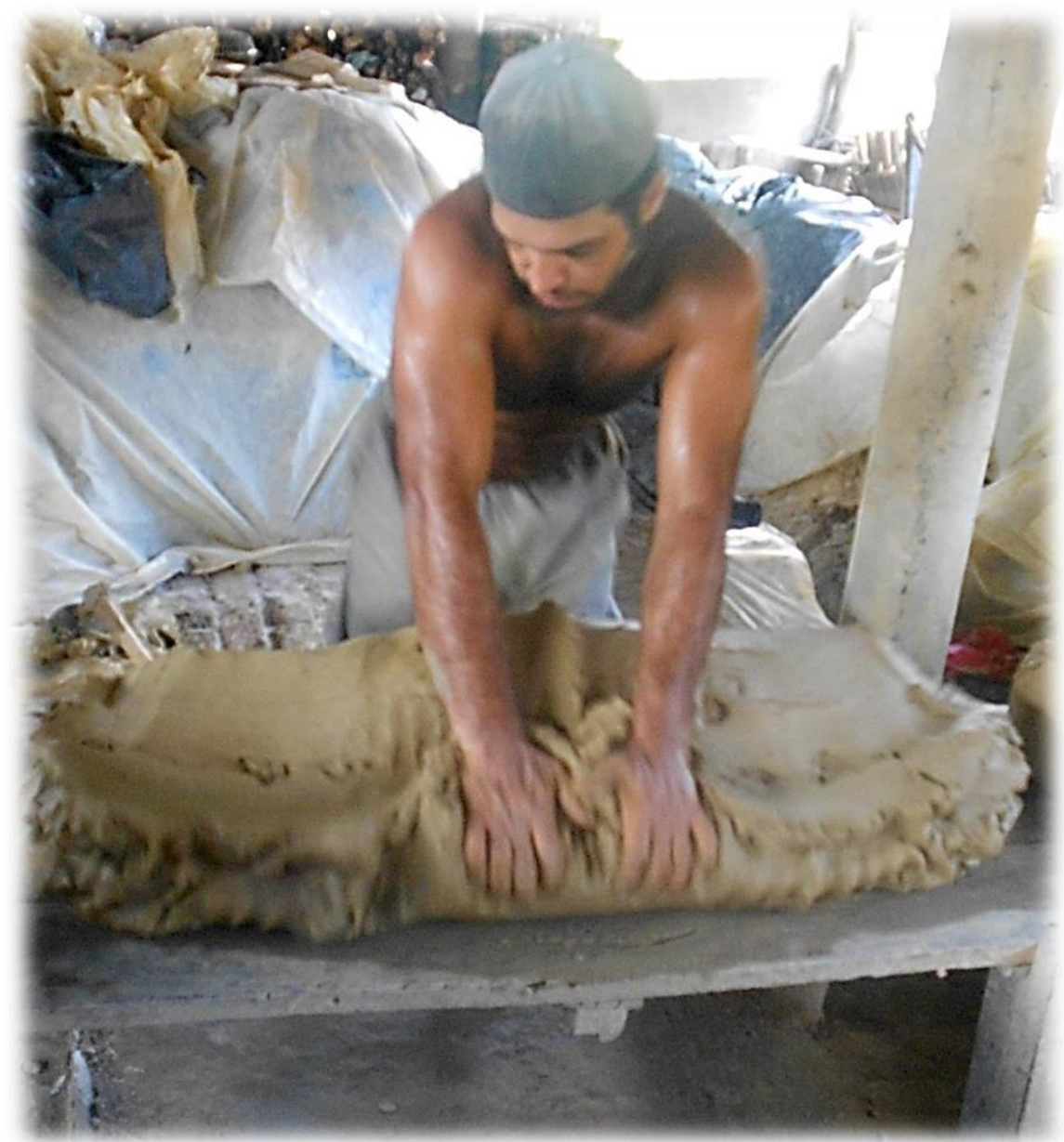

Amassador Irapuã amassando o barro no empelador 
O amassamento estabelece o relacionamento vivo com o barro, momento em que ocorre o despertar do cógito amassador, na busca por uma massa perfeita. O filósofo-poeta diz que as alegrias da mão que amassa emanam do equilíbrio alcançado no embate com a matéria, do sonho de uma massa perfeita.

A intimidade do sonho de uma massa perfeita vai tão longe, as convicções que ele proporciona são tão profundas, que se pode falar de um 'cógito' amassador. Os filósofos nos ensinaram a estender a outras experiências que não o pensamento o 'cógito' cartesiano. Falam-nos particularmente do 'cógito' biraniano no qual o ser encontra a prova da sua existência no próprio ato do seu esforço. A consciência da atividade para um Maine de Biran é tão direta como a consciência de um ser pensante. Mas as mais belas experiências será preciso obtê-las nos esforços bem sucedidos. A fenomenologia do 'contra' é uma daquelas que nos fazem melhor compreender os envolvimentos do sujeito com o objeto (Bachelard, 2001, p.65).

Entre os extremos do mole e do duro, do úmido e do seco, do pastoso e do rijo a mão conhece o barro justo. 
Matéria e mão devem estar unidas para formar o ponto essencial do 'dualismo energético', dualismo ativo que tem uma tonalidade bem diferente daquela do dualismo clássico do objeto e do sujeito, ambos enfraquecidos pela contemplação, um em sua inércia, outro em sua ociosidade (idem, ibidem).

O amassamento perscruta o interior do barro. O interior das coisas possui um espaço afetivo, diz Bachelard (2001, p.6), o trabalho com o barro busca tocar nesse mistério da matéria, em movimentos animados por belezas prometidas (grifos do autor). "De imediato, a imaginação material nos abre os porões da substância, nos entrega riquezas desconhecidas" (Idem, p.26). 


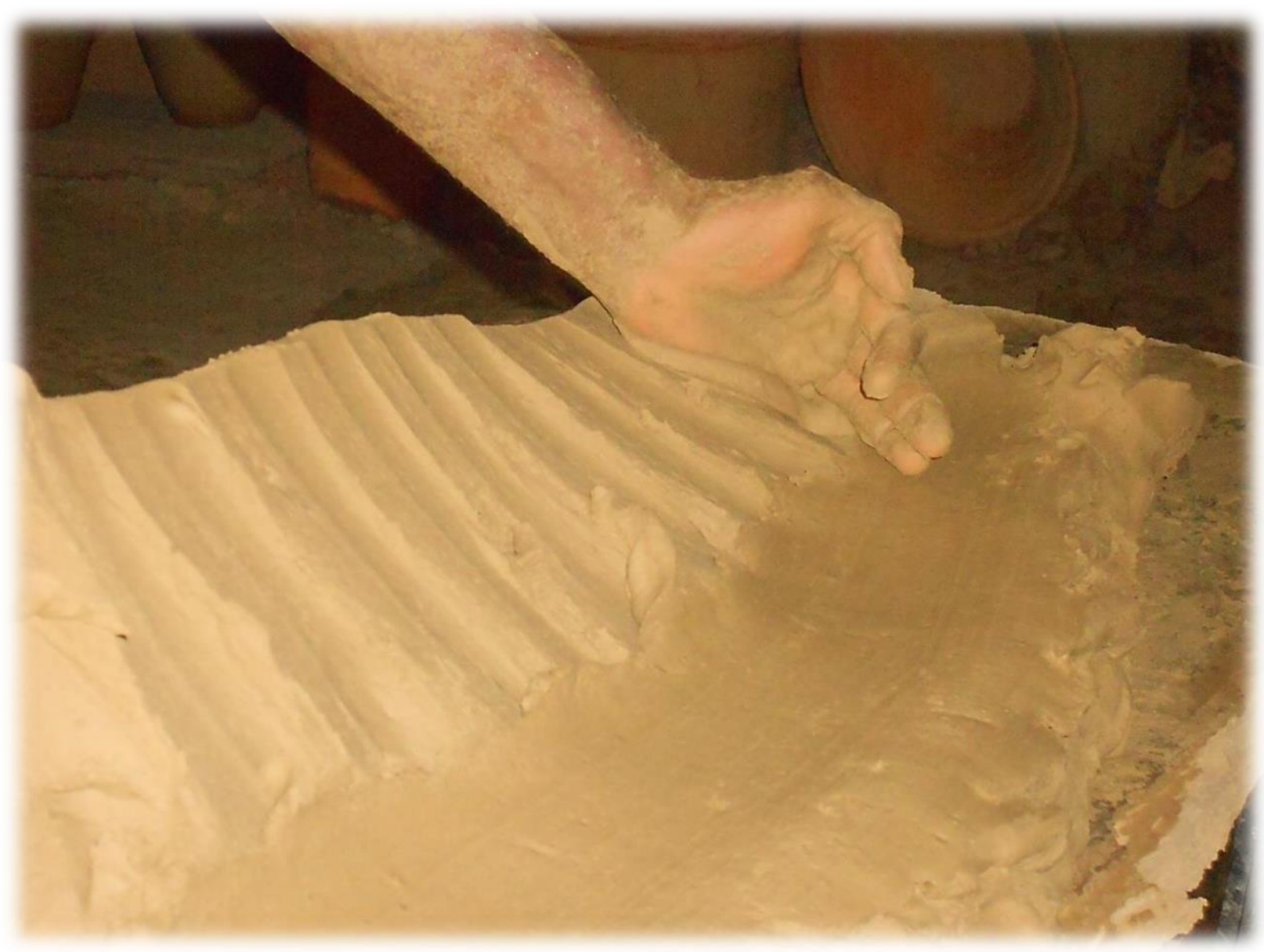

Mão do amassador em busca do barro justo 
No amassamento do barro, o "campo de presença" definido por Merleau-Ponty (2011), ou seja, a interação entre corpo e matéria descortina um território de possibilidades de exploração tátil que convoca todos os outros sentidos a esquadrinhar a massa. Bachelard $(2001$, p. 26) sustenta que a imaginação material dinamicamente vivida representa uma abertura em todas as direções e leva à superação do ser imediato, ao aprofundamento do ser superficial. No trabalho da matéria, as intimidades do sujeito e do objeto se tocam e se trocam.

$\mathrm{O}$ amassador divide o barro em pélas, medidas maragogipianas de tamanho e volume. São cinco as medidas das pélas, numeradas de 1 a 5 , de acordo com a peça que será realizada pelo oleiro. A péla recebe a forma de ovo achatado, um formato próprio para ir ao torno. Ela deve ser utilizada em pouco tempo, ou coberta por plástico para não ressecar. 


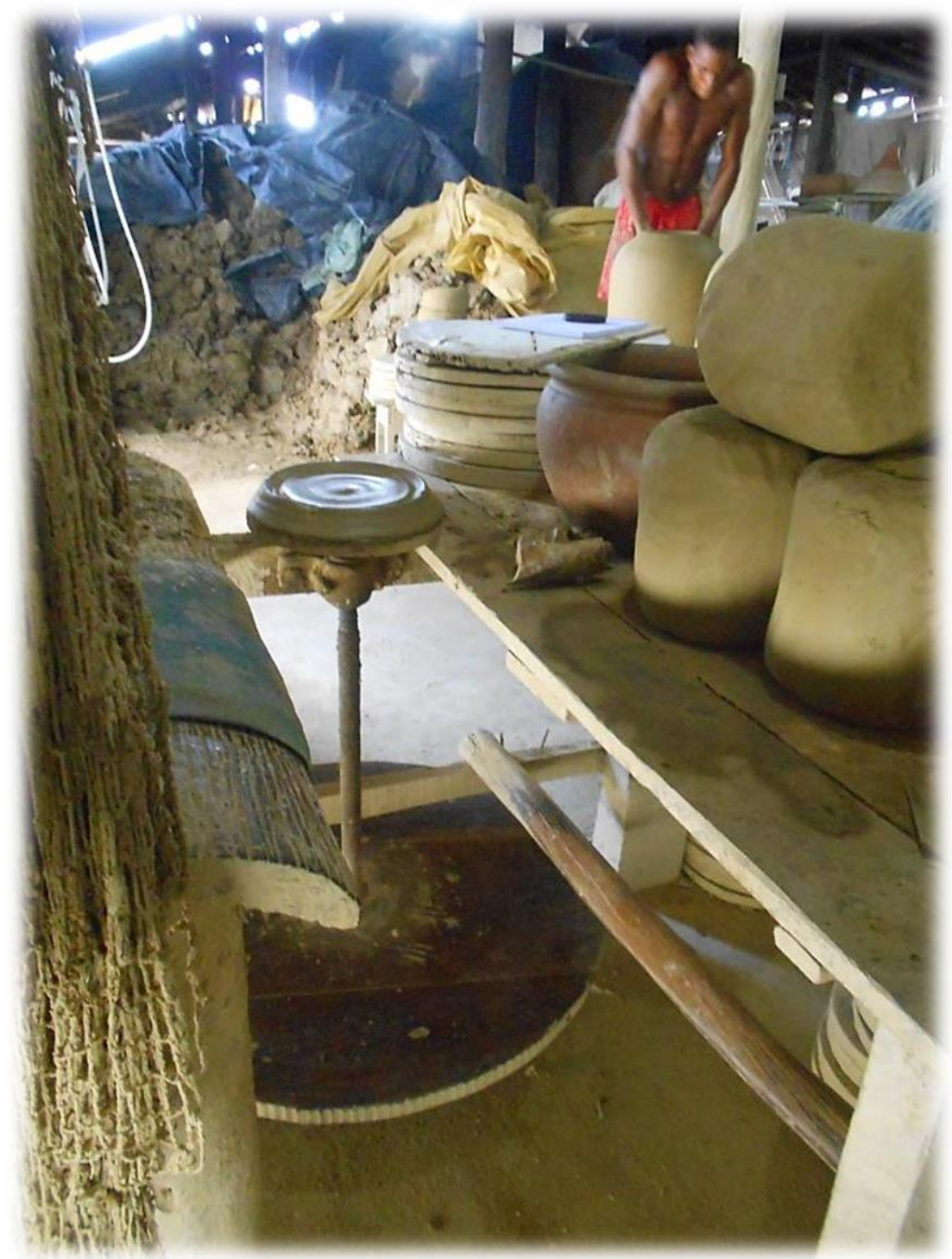

Pélas prontas para o uso na bancada do torno (amassador ao fundo) 


\title{
5.4.5. Fabricação das peças
}

\author{
O ceramista é um homem fora dos tempos \\ que, todos os dias, reatualiza a gênese \\ entre suas mãos, \\ inventando, organizando as formas e cumprindo, \\ em algumas horas de coç̧ão, \\ a metamorfose das noites geológicas. \\ Estranha é sua posição social - suspeita \\ para o honesto cidadão comum por sua cumplicidade \\ com o fogo e o mistério alquímico, \\ e em descrédito frente ao artista e ao intelectual \\ devido ao utilitarismo e à tecnicidade de seus produtos. \\ É, ao mesmo tempo, pai do objeto que se usa no cotidiano \\ e criador do material mais indestrutível que há, \\ tesouro e referência para os arqueólogos. \\ O ceramista vive esquartejado \\ entre seus quatro elementos. \\ Mas é por meio deles que estabelece \\ um contato cósmico que lhe é essencial \\ e que constitui, ao mesmo tempo, \\ sua humildade e sua riqueza.
}

Antoine de Vinck

Com as pélas prontas, o oficial oleiro começa seu trabalho, que pode ser no torno ou manualmente. O oficial é a autoridade dentro da olaria. Intérprete de sua cultura, ele atua como um reprodutor de práticas recolhidas em seu meio social, bem como um criador. O oficial possui elevada destreza e disciplina manual. 
O barro, por seu lado, produz fascinação em quem nele se embrenha. O oleiro adentra um mundo cujos segredos ancestrais se revelam a partir do domínio da técnica. A ação de transformar a matéria (e de ser transformado por ela) vasculha raízes, esferas de seu passado biológico e cultural. No tempo presente, o barro recebe dos sonhos do criador todo um futuro de quefazeres e oferece-lhe esquemas temporais bem definidos à sua paciência.

\footnotetext{
Uma matéria-duração é aqui uma emergência dinâmica acima de um espaço-tempo. E mais uma vez, nessa matéria-duração, o homem se realiza antes como devir do que como ser. Conhece uma promoção de ser (Bachelard, 2001, p. 19).
}

Quando damos forma ao barro, o tempo assume uma realidade material: há um tempo da terra, um tempo da água, um tempo do fogo, um tempo que se dialetiza no esforço do trabalhador e na resistência da matéria. "Através do duro e do mole aprendemos a pluralidade dos devires, recebendo provas bem diferentes da eficácia do tempo (idem, p.16)." O santeiro Rozalvo conhece bem os tempos da cerâmica: 
Tem que ser sem pressa. Porque, repare, se eu levar uma semana pra fazer a peça, se chegar lá e quiser queimar com pressa eu vou perder aqueles dias que eu trabalhei, a peça, o valor que eu ia ganhar, vou ter que fazer outra. Então, tem que pensar que a pressa é inimiga da perfeição.

Os tempos da cerâmica são diversos e respeitam profundamente a coexistência entre os tempos da terra, do ar, da água, do fogo e do humano. Modelamos e torneamos a argila em um estado de moderada hidratação, uma massa úmida no ponto de descolar das mãos. Fazemos acabamentos, pintamos com engobe, agregamos ornamentos, alças, tampas, bicos, quando a peça está em "ponto de couro", ou seja, encontra-se ainda úmida, mas já estruturada, em estado semiduro. Polimos quando a peça encontra-se em "ponto de osso", isto é, praticamente seca, mas com um mínimo de umidade, com a temperatura ainda fria. Queimamos, quando a peça encontra-se bem seca, sem mais água em suas entranhas.

Nakano diz que a importância do relacionamento do ceramista com a terra, a água, o ar e o fogo não está apenas no fato de lidar com matéria e energia: 
Compondo minerais, manipulando a ação do calor e do ar sobre a argila, ele [o ceramista] busca o equilíbrio entre esses elementos no seu plano material e energético e acaba encontrando seu próprio equilíbrio no mundo. O ceramista lida incessantemente com polaridades: as energias conservadoras e intensivas da terra e as energias manipulativas e expansivas do fogo; a plasticidade da argila e a volubilidade do fogo; a horizontalidade da terra e da água (que estão relacionados com a gravidade) e a verticalidade do fogo (que é leve, sobe e se espalha). Cabe ao ceramista a manutenção do equilíbrio entre essas duas polaridades que está em atuação contínua e recíproca (Nakano, 1989, p. 73).

A atividade de um oleiro requer muito tempo de prática e dedicação. Geralmente, eles chegam à olaria com o nascer do sol e saem somente quando ele se põe. $A$ maioria trabalha aos domingos, quando a frequência de turistas aumenta. Seu Zé me disse que "mesmo que você não queira, o barro fica te chamando para o trabalho":

Eu já pesquei, sei plantar uma roça, já fiz todo o tipo de coisa. Agora, eu me dedico mesmo é só para o artesanato. Uma vez eu disse uma coisa e me responderam: 'não diga isto!'. Mas é verdade: o artesanato é quase um trabalho escravo. Eu gosto, eu me jogo pra aquilo. Quando eu falo 
determinadas coisas... A gente que trabalha com cerâmica sabe que é assim, você puxou aqui uma peça, se não vir dar o término, perdeu a peça. (...) Botou o pé na olaria, tem sempre trabalho pra fazer. (Seu Zé).

Observei nos oleiros a aspiração pela excelência no trabalho manual. Sennett (2008, p. 30) afirma que o artífice representa uma condição humana especial: a do engajamento, a da obsessão pelo bem feito.

Você sempre tem que ter qualidade no seu produto, é a sua marca. Eu produzo do meu jeito, mas com qualidade (Nelinho).

Sempre devagar para poder atingir a perfeição (Rozalvo).

\subsubsection{A mão-ferramenta e as ferramentas}

No trabalho com o barro muitas vezes, desprezamos ferramentas em prol das mãos: há certas ocasiões em que a ponta do dedo indicador ou polegar, o nó do dedo médio, um canto de unha ou a palma da mão podem mais bem ajudar a dar forma ao barro do que qualquer ferramenta. 
De maneira geral, os oleiros de Maragogipinho usam poucas ferramentas. A táfica é uma das ferramentas mais utilizadas para ajudar a erguer a peça no torno, ou para raspá-la na fase de acabamento. Consiste em um pedaço de bambu afiado, ou cano de PVC. A simplicidade das ferramentas pode ser visualizada abaixo.

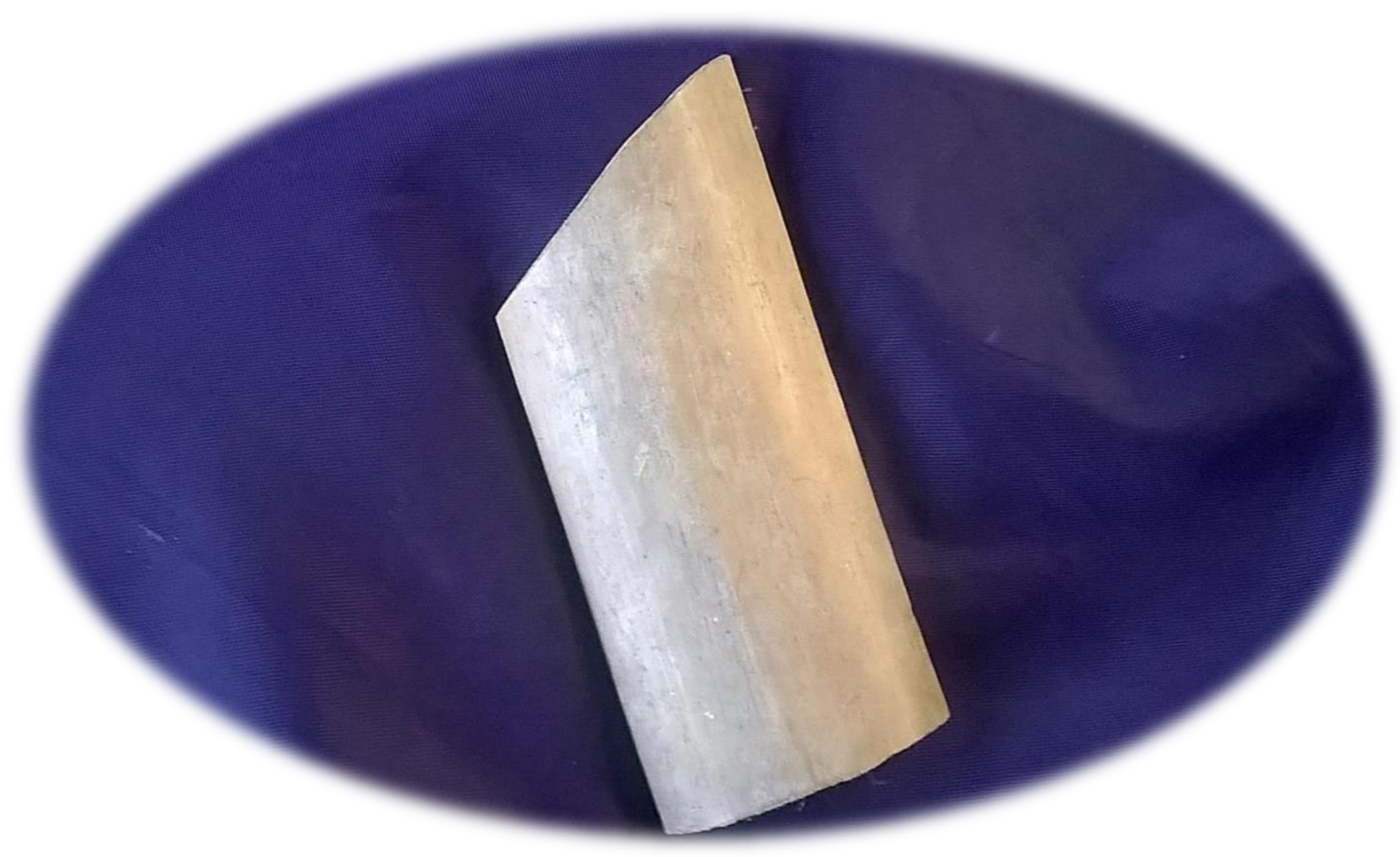

Táfica do oleiro Padre 


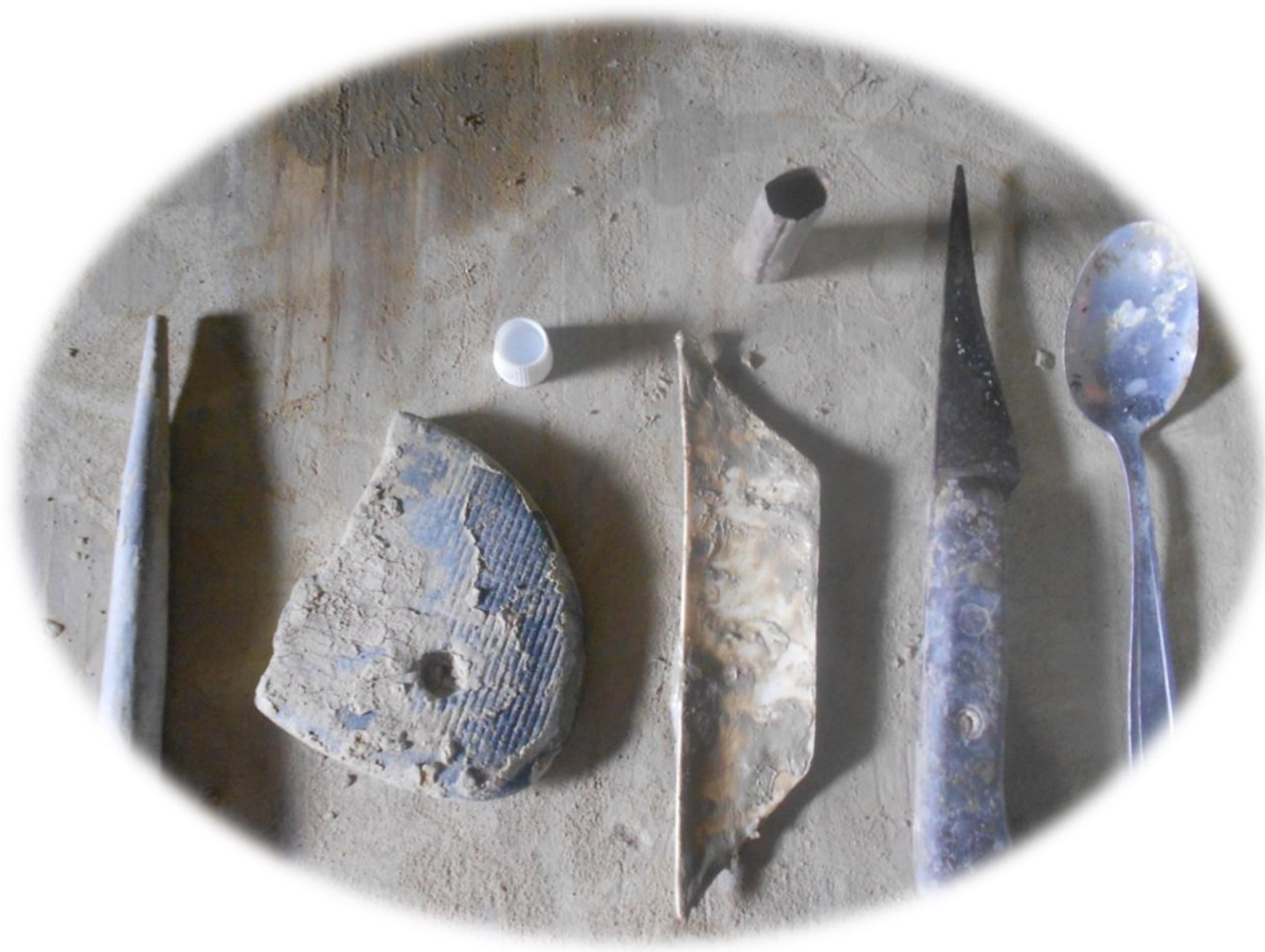

Ferramentas do oleiro Tutuna

O oleiro emprega a mão, os dedos tornam-se ferramentas e as ferramentas externas passam a ser extensões de seu próprio corpo. O uso da ferramenta 
possibilita uma expansão da mão. Quando utiliza uma ferramenta, o artesão não pensa na mão e na ferramenta como entidades diferentes e separadas.

A mão já não é uma mão quando agarra o martelo, é o martelo mesmo, que já não é um martelo, senão que voa transparente entre o martelo e o prego, desaparece e se dissolve; minha própria mão fugiu enquanto escrevo. A mão e o pensamento, como a língua, desaparecem em suas determinações (Serres, apud Pallasmaa, 2009, p. 51).

A ferramenta se desenvolveu para ser parte da mão. O uso e o descarte, bem como o aperfeiçoamento, vêm possibilitando um processo evolutivo das ferramentas. As ferramentas básicas, como a faca, o martelo, a tesoura, o serrote, foram refinadas ao longo do tempo pelas diferentes culturas.

Pallasmaa (2009, p. 52) identifica uma linha genética em determinadas ferramentas, como por exemplo, as ferramentas japonesas, que são facilmente diferenciadas das ferramentas escandinavas ou norte-americanas. Para o autor, o funcionamento e a aparência da ferramenta refletem inevitavelmente a atitude particular de uma cultura para o trabalho e o valor social que lhe é outorgado. 

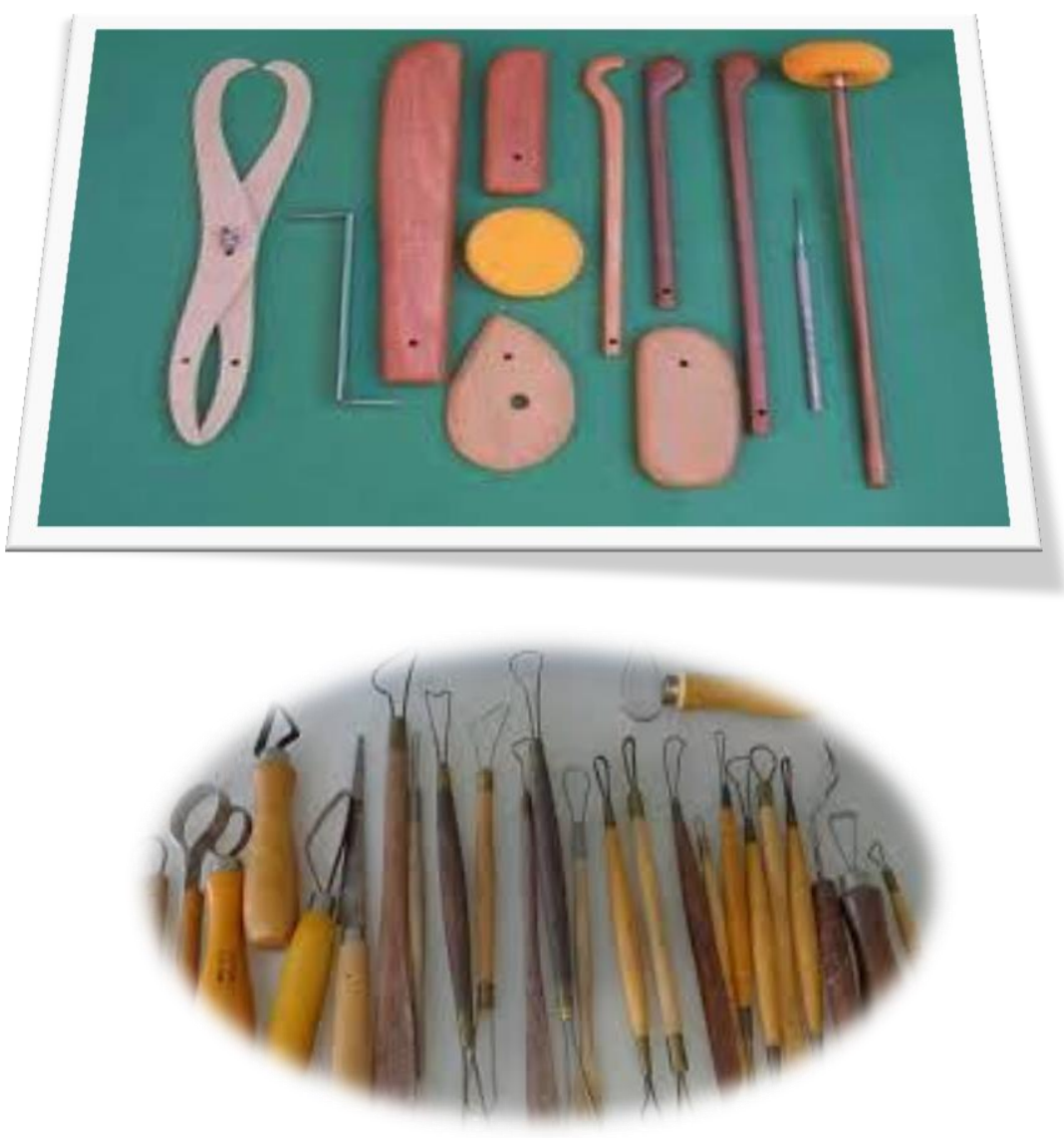

Ferramentas fabricadas para cerâmica

As ferramentas possuem beleza e convidam para o seu manuseio. Na história, deparamo-nos com inúmeras ferramentas que agregam ornamentos, inclusive em 
utensílios de pedra primitivos. Esses enfeites não são geralmente funcionais, porém respiram sofisticação e atendem a necessidades estéticas primordiais. Em seu reino de funcionalidade e beleza, as ferramentas oferecem prazer ao usuário. Comumente são objetos anônimos de uma longa tradição de uso e de aprimoramento sucessivos.

\subsubsection{O torno, ferramenta viva}

O torno de roda é a ferramenta de excelência em Maragogipinho. Geralmente fica localizado no melhor espaço da olaria, ou logo na entrada, beneficiando-se da ventilação e da iluminação natural. Os tornos são feitos de madeira, com o eixo central de ferro.

O artesão que sabe tornear, o oleiro, tem certo prestígio social na comunidade. Ele fica semi-sentado em uma bancada, o corpo permanece na vertical para poder fazer o eixo do torno girar com um dos pés, enquanto as mãos se ocupam do objeto torneado. Alguns oleiros trabalham descalços, outros calçam um sapato velho. 


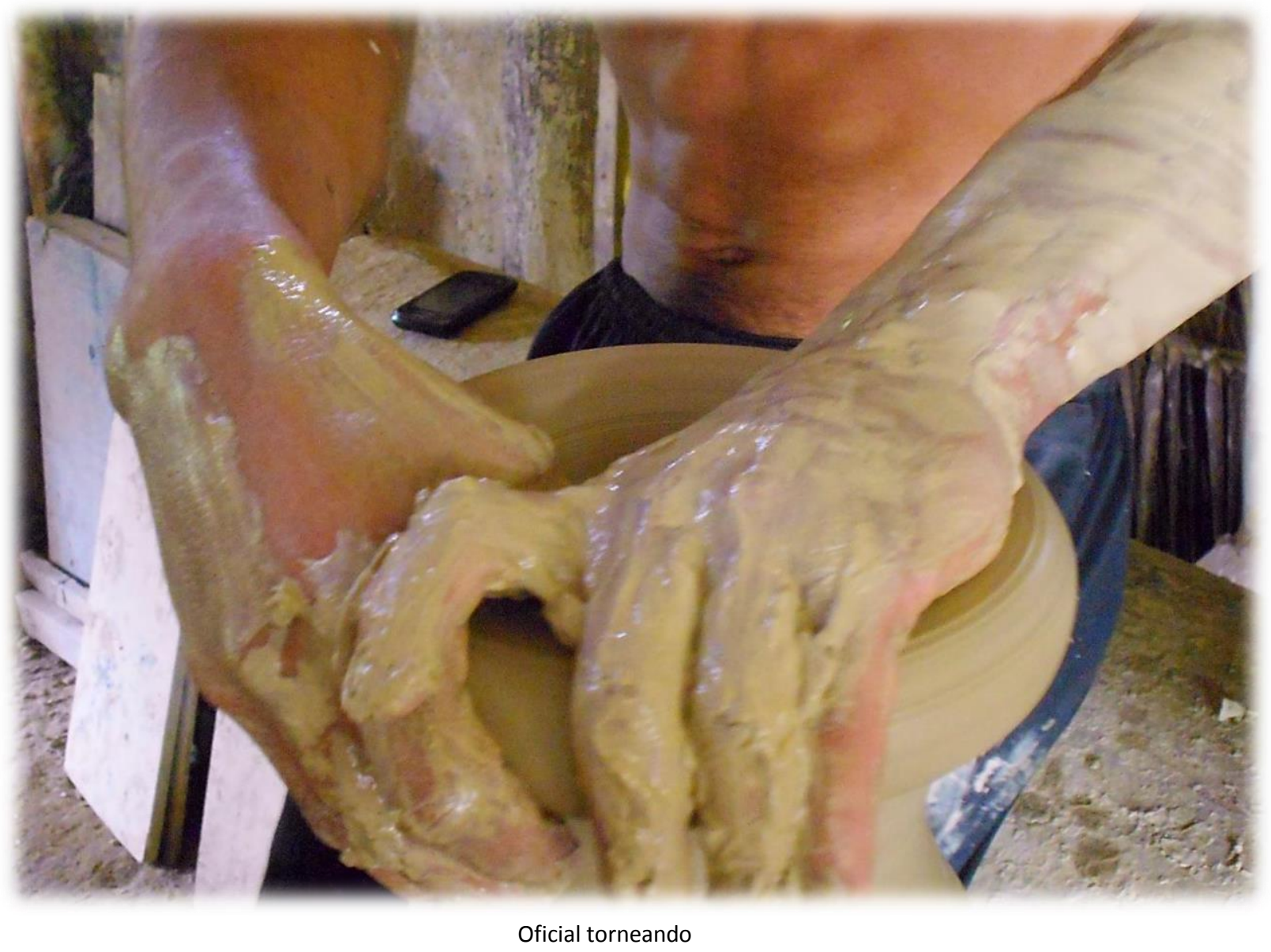


A invenção do torno ocorre por volta de 6000AP em território hoje ocupado pelo Iraque (Sennett, 2008, p.139). Na Grécia antiga, os tornos dos oleiros eram pesados discos de madeira ou pedra, girando ao redor de um suporte pontiagudo

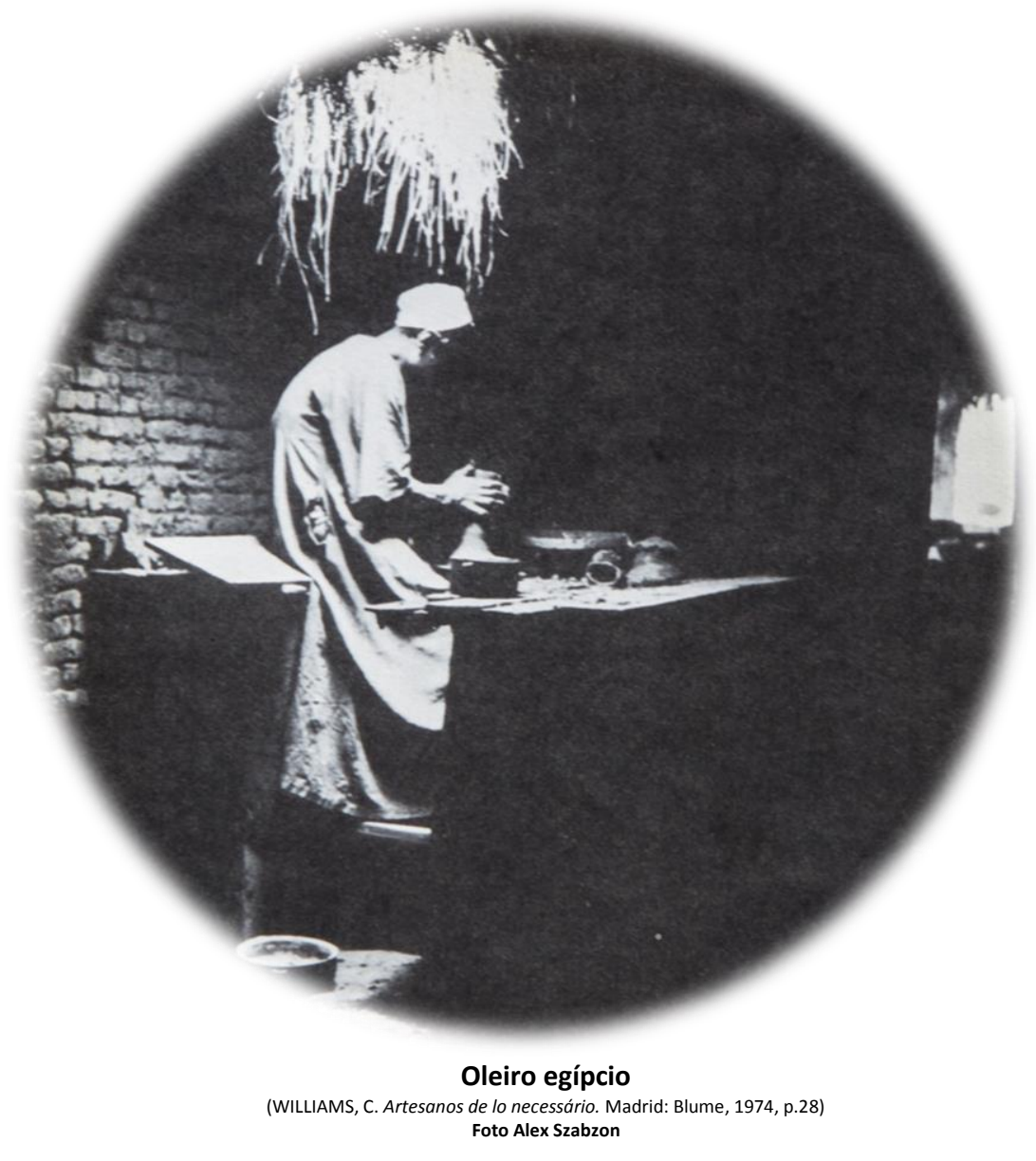
de pedra. Antes do torno, pratos, potes e panelas eram feitos a partir de rolos de barro que iam sendo sobrepostos. O torno representou um passo importante na confecção dos objetos utilitários, permitiu ao artesão erguer sua peça a partir de um único bloco de argila.

de lo necessário. Madrid: Blume, 1974, p.28) 


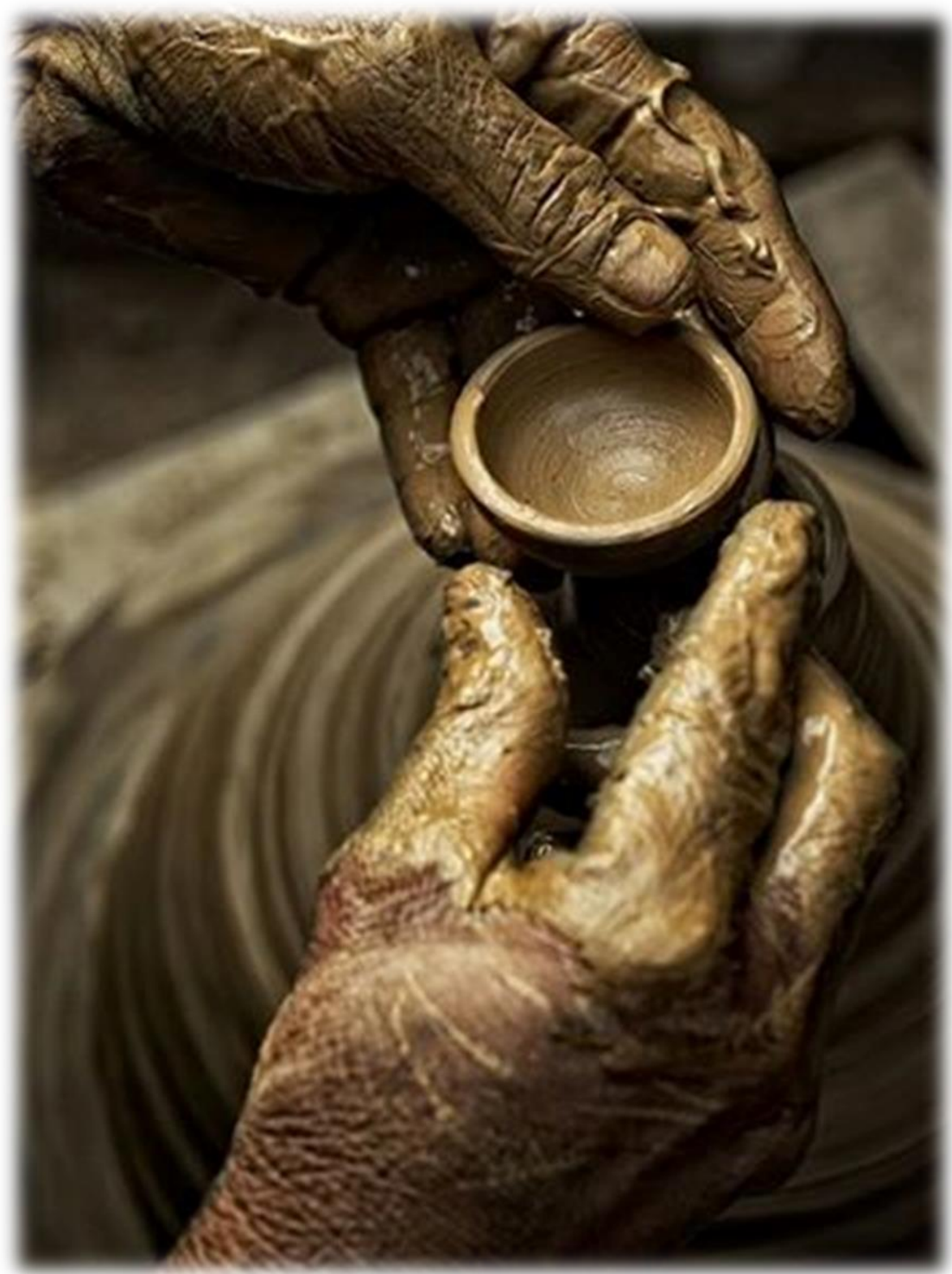

O torno é uma ferramenta que exige habilidade das duas mãos. A assimetria manual é algo a ser superado quando se trabalha no torno. A mão mais fraca (a esquerda, na maioria dos seres humanos) necessita se fortalecer e aprender movimentos que antes eram exclusivos da outra mão. A mão direita, para muitos a mais hábil, cede espaço para a esquerda, 
numa espécie de cooperação fraterna. A cooperação entre as duas mãos é descrita sensivelmente por Focillon:

\begin{abstract}
Elas não são um par de gêmeas passivamente idênticas. Não se distinguem uma da outra à maneira da caçula e da primogênita ou como duas moças de dotes desiguais, uma afeita a todas as destrezas, a outra, serva embotada na monotonia prática dos trabalhos grosseiros. Não faço fé, em absoluto, na eminente dignidade da direita. Quando a esquerda Ihe falta, ela recai numa solidão difícil e quase estéril (Focillon, 2012, p.8).
\end{abstract}

No torno, precisamos primeiro centralizar o barro antes de erguer as paredes. A centralização demanda grande força e habilidade das mãos. O corpo contém e dociliza a massa enquanto ela gira sobre o eixo. Esse movimento é também centrípeto, faz com que a argila revele todas as suas regiões mais recônditas, o seu centro, zona de difícil acesso, mas que precisa ser alcançado para que as moléculas da matéria obtenham um estado de equilíbrio, antes que voltem a mover-se novamente para dar forma ao objeto.

Eliade (1992, p. 26) nos mostra que o centro é o âmbito do sagrado, a região da realidade absoluta. Em geral, os símbolos da realidade absoluta (árvores da vida, 
fontes da juventude) encontram-se em lugares centrais e o caminho até eles é penoso já que representa a passagem do profano para o sagrado, da morte para a vida, do homem para a divindade. $\mathrm{O}$ ato da criação, a partir do centro, realiza a passagem daquilo que não é manifesto para o que é manifesto. Para o autor, toda criação repete o ato cosmogônico preeminente, a criação do mundo e, consequentemente, qualquer coisa que é constituída tem a sua fundação no centro do mundo.

O torno é uma ferramenta que oferece ao corpo experiências indescritíveis de extensão das mãos e de expansão da mente. As mãos que torneiam se amalgamam ao barro e atingem uma dimensão em que quase deixam de serem mãos, como se dissolvessem entre o torno e o barro. Em lugar de tornear o barro, o torno possibilita ao torneiro tornear-se a si mesmo.

Depois de torneada, a peça vai para a secagem dentro da olaria, na sombra. Comumente, é o ajudante quem retira as peças da bancada e as coloca numa tábua chamada pará, no interior da olaria, à sombra, para que o ar inicie o processo de secagem. Grande parte delas necessita de retoques como a colagem de alças, pés, tampas, orelhas, chifres, ou a emenda de outras partes em objetos grandes. Essa etapa do trabalho tem de esperar pelo momento certo da secagem, 
pode ser feito pelo próprio oleiro ou pelo emendador. Algumas peças, como o porrão, por exemplo, ainda precisam voltar para o torno antes de secarem totalmente, para tirar o excesso do fundo e dar a forma final. Outras, ainda passam pelo processo de tapação, em que são tampadas eventuais imperfeições.

Quando as peças estão praticamente enxutas, podem ser levadas ao sol e ao vento para finalizar o processo de secagem. 


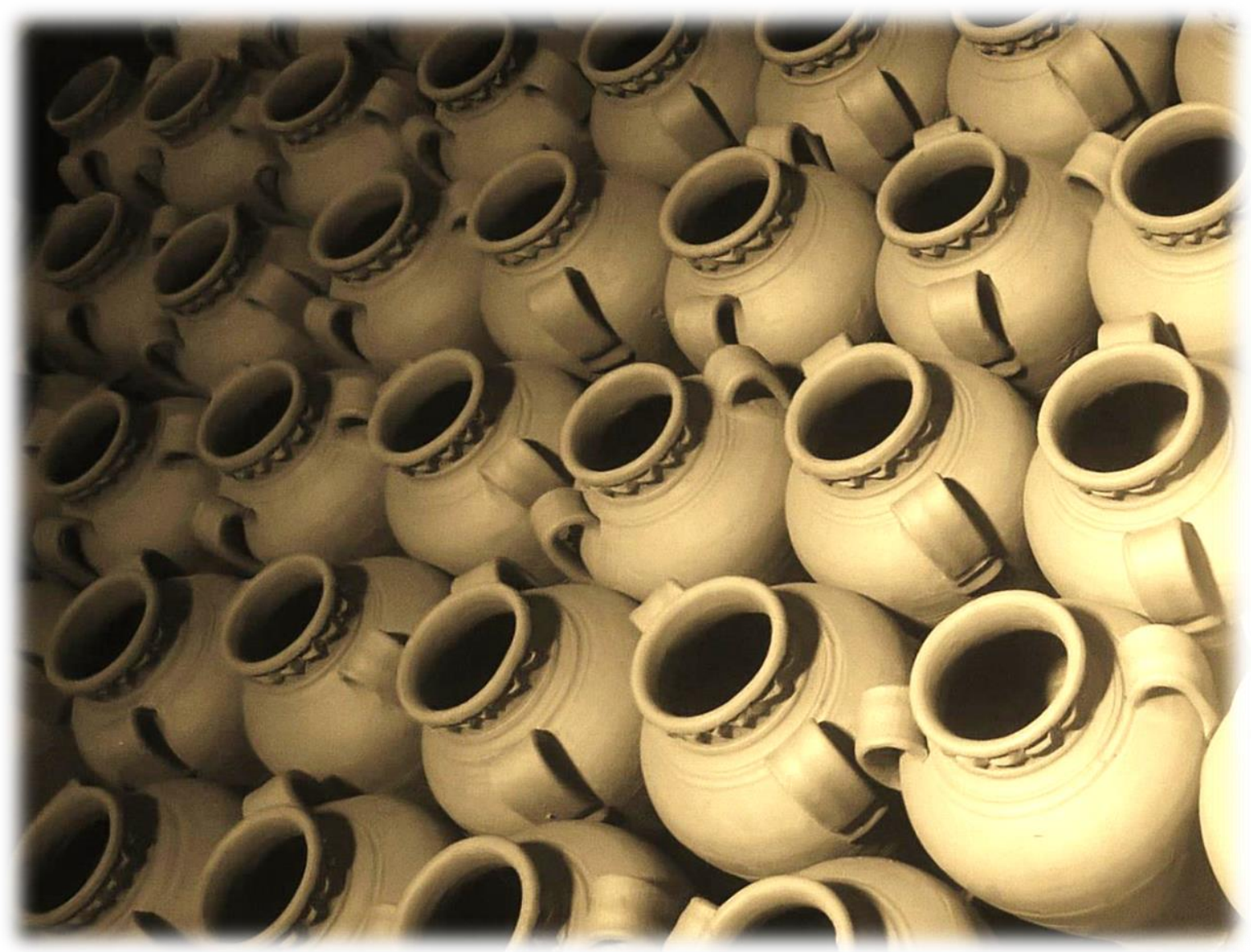

Talhas secando no interior da olaria 


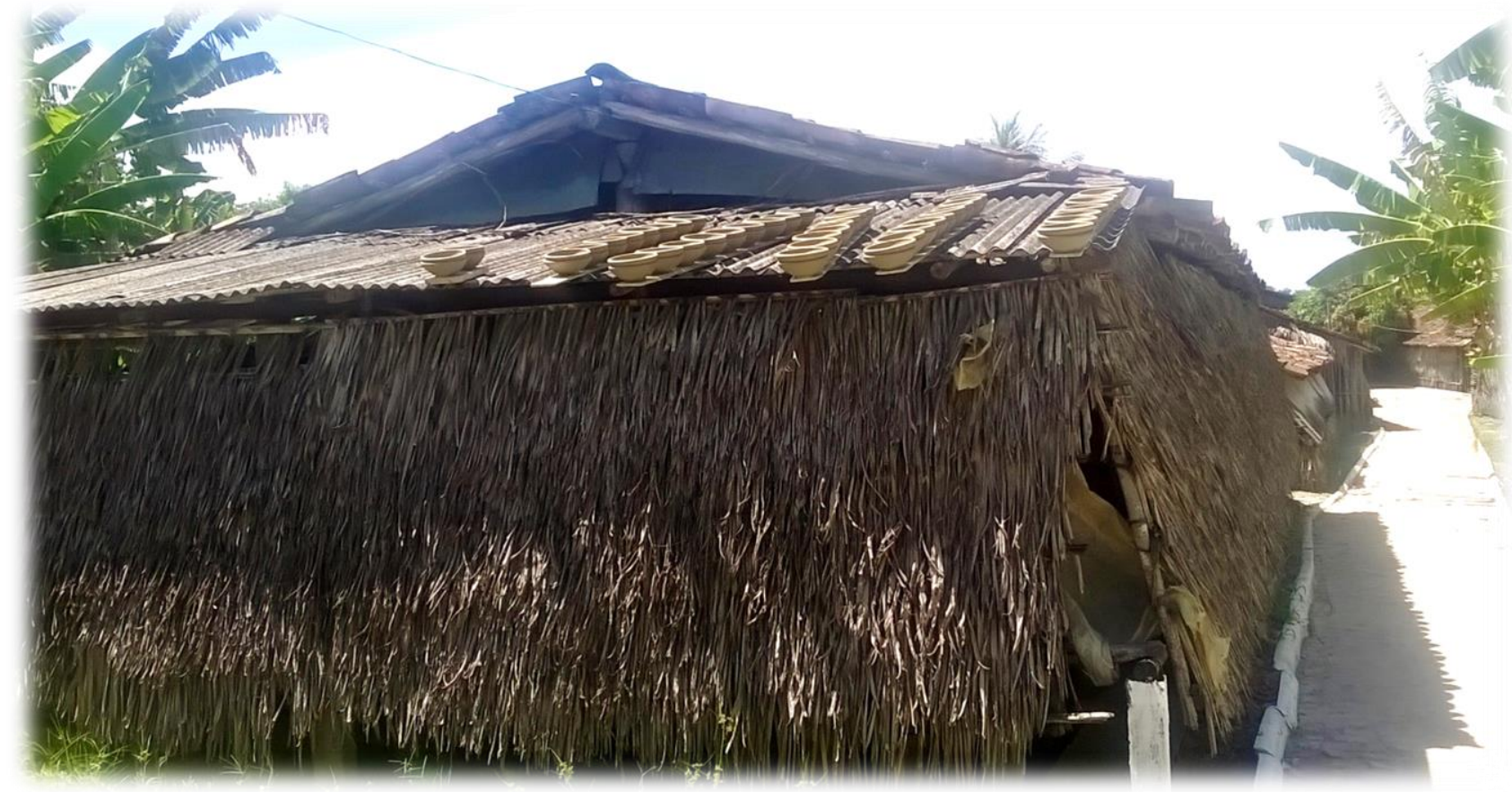

Vasos secando ao sol

\subsubsection{Brunição}

Com as peças semi-secas, inicia-se o trabalho feminino. A brunição, brunimento, ou ainda burnição, consiste no polimento do objeto de barro com uma pedra lisa (seixo ou quartzo) e um trapo ou saco plástico enrolado nos dedos. A brunideira ou burnideira pode realizar esse trabalho na olaria ou em sua residência. É mais 
comum que as mulheres que brunem nas olarias sejam parentas do oleiro, esposas ou filhas. As que trabalham por conta própria geralmente o fazem em casa.

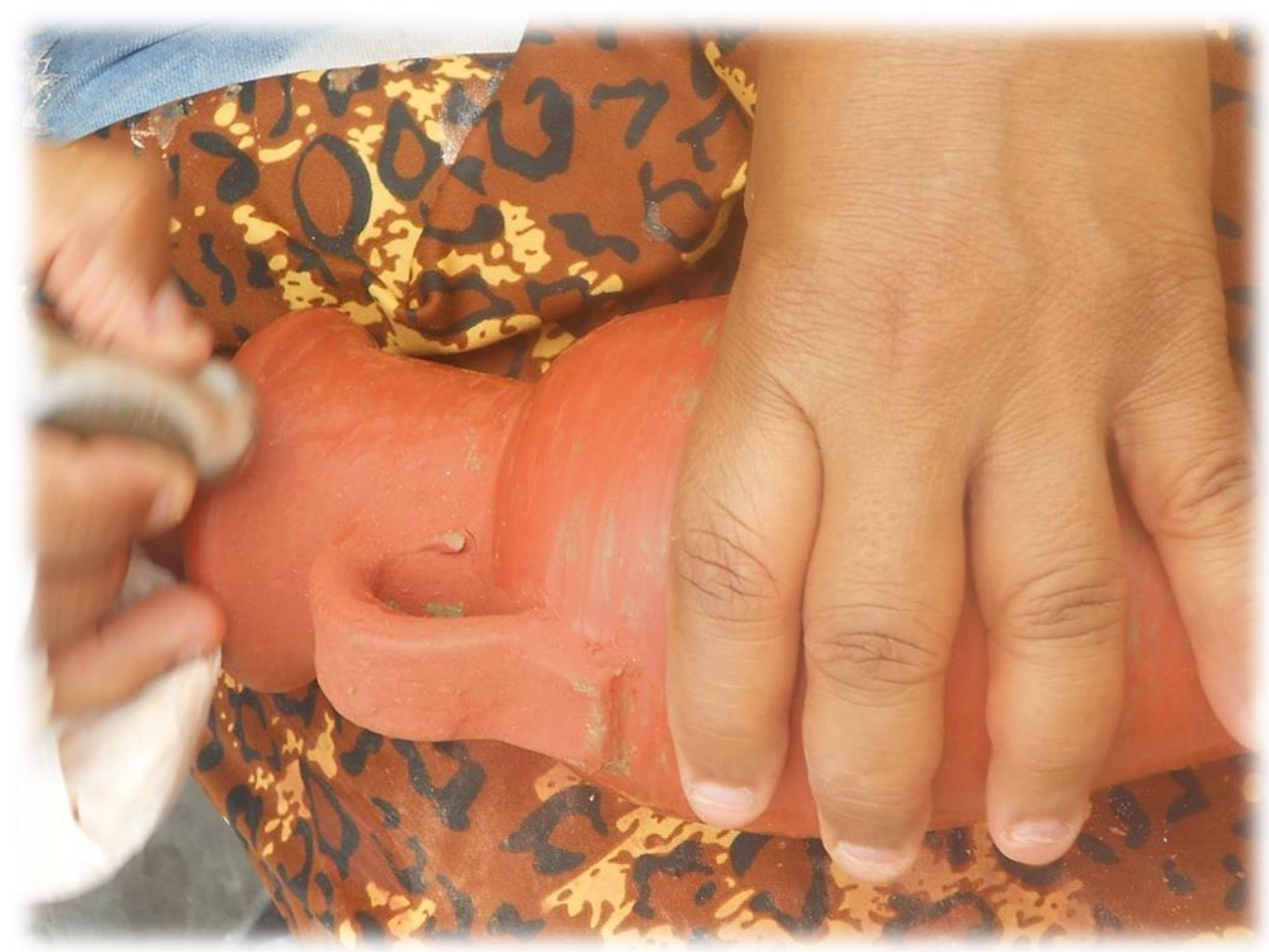

Brunimento de uma talhinha pintada com tauá

O oleiro é quem decide como quer o acabamento, que pode ser: 
- $\quad$ Ao natural, sem pintura. A brunição realça a cor natural do barro.

- Com a pintura do tauá, que dá um tingimento vermelho. A brunideira aplica o engobe vermelho com o auxílio de um pincel grosso de fios de barbante, a panata, feita por ela mesma. Deixa a peça secar um pouco e em seguida dá brunimento.

- Com a pintura do tauá e da tabatinga. A brunideira aplica o tauá, espera secar, brune e depois pinta detalhes com a tabatinga, engobe branco.

- A pintura com tinta a frio, depois de queimada a peça.

Atualmente, a maioria dos oleiros aplica o tauá. A pintura requer conhecimento da técnica. Algumas brunideiras não a executam.

\subsubsection{Pintura}

A pintura das peças é uma atividade exclusivamente feminina. Muitas pintoras são esposas ou filhas de oleiros. Na maioria das vezes, elas pintam em suas próprias casas, dividindo seu tempo entre a decoração do barro e os afazeres domésticos.

O reconhecimento da cerâmica de Maragogipinho se faz, principalmente, pelas características tradicionais da pintura com motivos florais pintados com pigmentos 
minerais: tabatinga sobre tauá. Cada pintora tem seu estilo próprio, o movimento das pinceladas em tabatinga oferece infinitas possibilidades de exploração gráfica e transmite um valor cultural significativo para a identidade local. A pintora delineia diretamente com o pincel, sem passar por esboços. Os motivos pintados são geralmente flores: margaridas, dálias, miosótis. Esses motivos constituem o fator responsável pela originalidade da louça de Maragogipinho: quanto mais fino for o traço dos desenhos, mais valorizada ficará a peça (Ferraz, 2009, p.18).

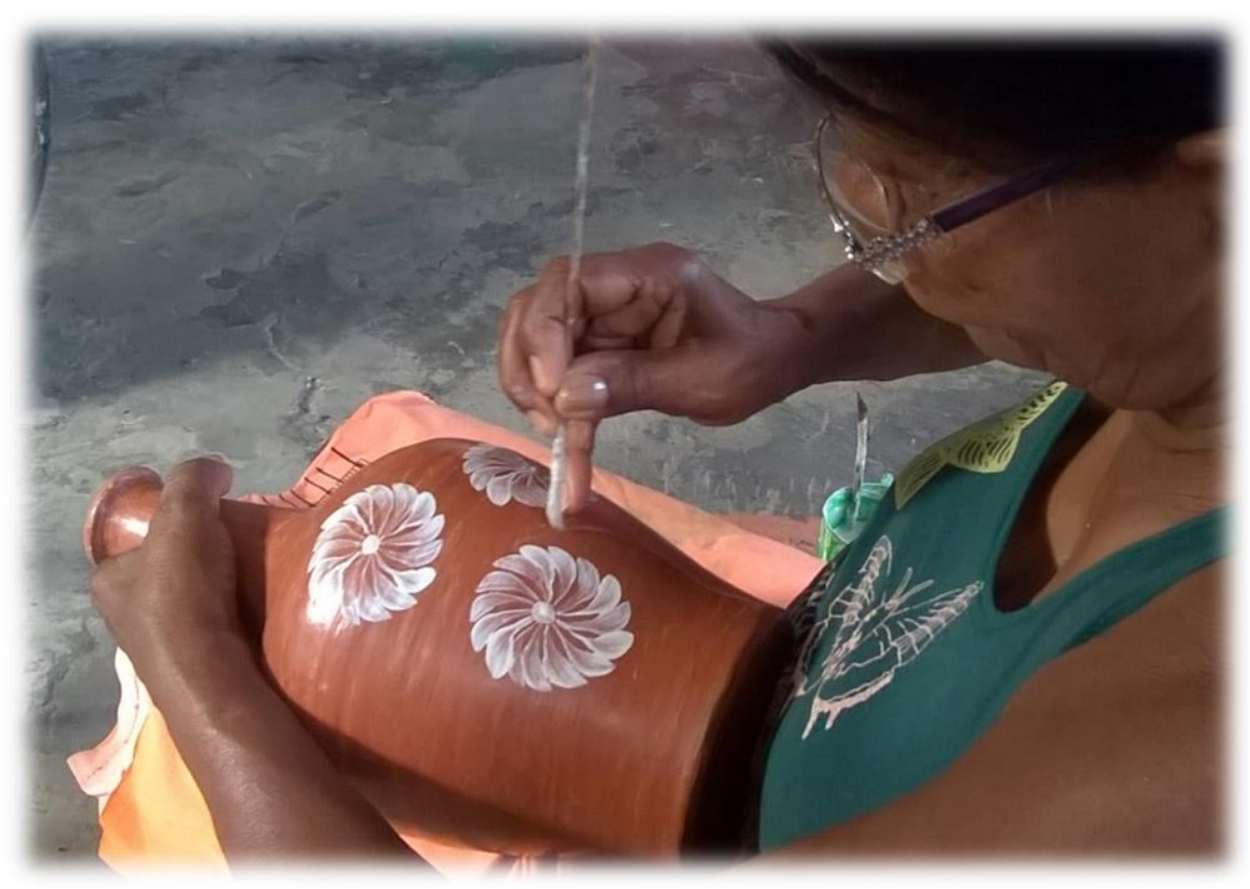

Zelita pintando uma moringa com tabatinga 
A pintora é quem prepara o tauá e a tabatinga, guardados posteriormente em garrafas pet. Esses engobes passam por processos de decantação e limpeza antes de poderem ser utilizados.

O pincel artesanal é também fabricado pela pintora, com pelos do lombo do gato amarrados a taliscas de palha de coqueiro. Algumas delas me revelaram que esse tipo de pincel é mais apropriado para a pintura em tabatinga por causa da maciez e caimento do pelo. Ele ajuda numa confecção mais minuciosa dos detalhes.

Pincel de talisca de palha de coqueiro com pelo de gato 
Os ornatos, cuja estilização é resultado do uso da talisca em traços rápidos sobre o fundo vermelho da peça, produzem um efeito dos mais singulares da arte popular brasileira (Ferraz, 2009, p. 20).

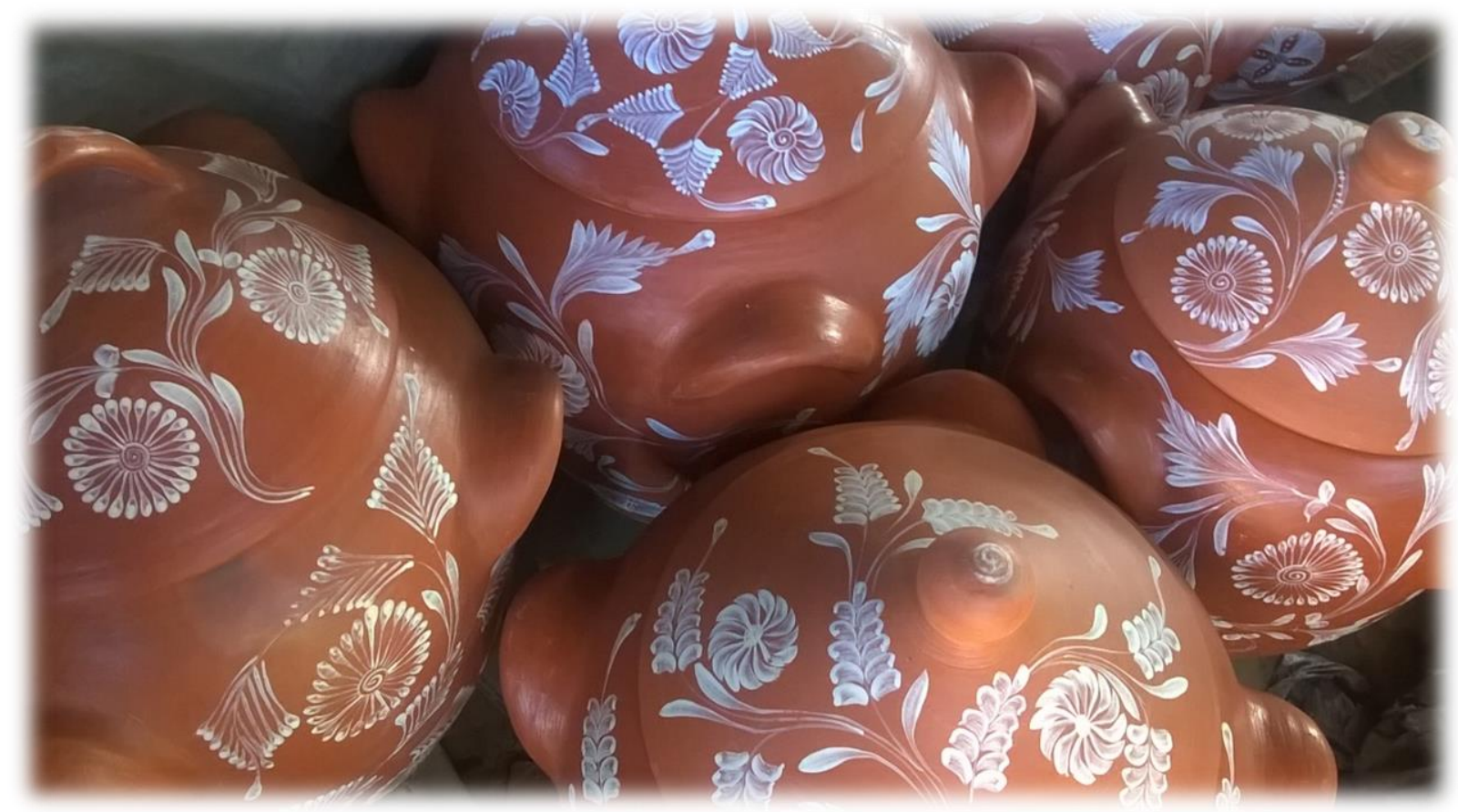

Sopeiras pintadas com tauá e tabatinga

(oleiro: Padre, pintora: Zelita) 
Algumas pintoras utilizam a tinta a óleo, que também tem tradição na pintura das peças. De um tempo para cá, começaram a utilizar em larga escala a tinta acrílica, que tem bastante aceitação pela rapidez de secagem.

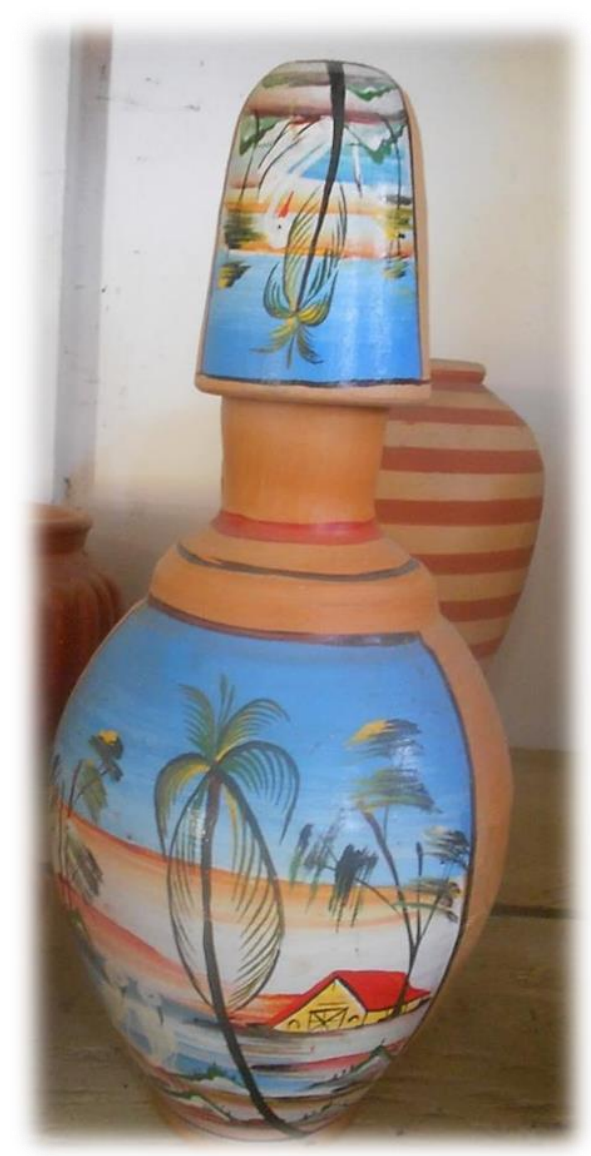

Moringa pintada com tinta a óleo Acervo da AAMON 


\subsubsection{Queimas}

Consoante a pá se ia aproximando do fundo da cova, as cinzas tornavam-se mais quentes, mas não tanto que queimassem, estavam simplesmente tépidas, como pele humana, e macias e suaves como ela.

Cipriano Algor pôs de parte a pá e afundou as duas mãos nas cinzas. Tocou a fina e inconfundível aspereza dos barros cozidos.

Então, como se estivesse a ajudar a um nascimento, segurou entre o polegar e os dedos indicador e médio a cabeça ainda oculta de um boneco e puxou para cima.

Calhou ser a enfermeira.

Sacudiu-lhe as cinzas do corpo, soprou-lhe na cara, parecia que estava a dar-Ihe uma espécie de vida, a passar para ela o hausto dos seus próprios pulmões, o pulsar do seu próprio coração.

Saramago, 2000, p. 202

Em Maragogipinho, é mais comum que os objetos recebam uma monoqueima, ou seja, vão ao forno uma única vez. A queima é efetivada depois da pintura com tabatinga ou antes da pintura a frio com tinta acrílica. As peças retornam da casa da pintora para a olaria, onde são organizadas dentro do forno. A arrumação do forno é feita pelo arrumador de forno e/ou pelo oleiro, e representa uma etapa 
importante. Uma boa arrumação pode garantir a resistência e durabilidade das peças depois de queimadas.

Se houver muitas ou grandes peças a serem queimadas, o oleiro utiliza o forno de capela, fechado, com teto abobadado, que consome mais lenha e horas de queima. Para pouca quantidade, ou para peças pequenas, utiliza o forno caieira, aberto, que consome menos lenha e tempo de queima.

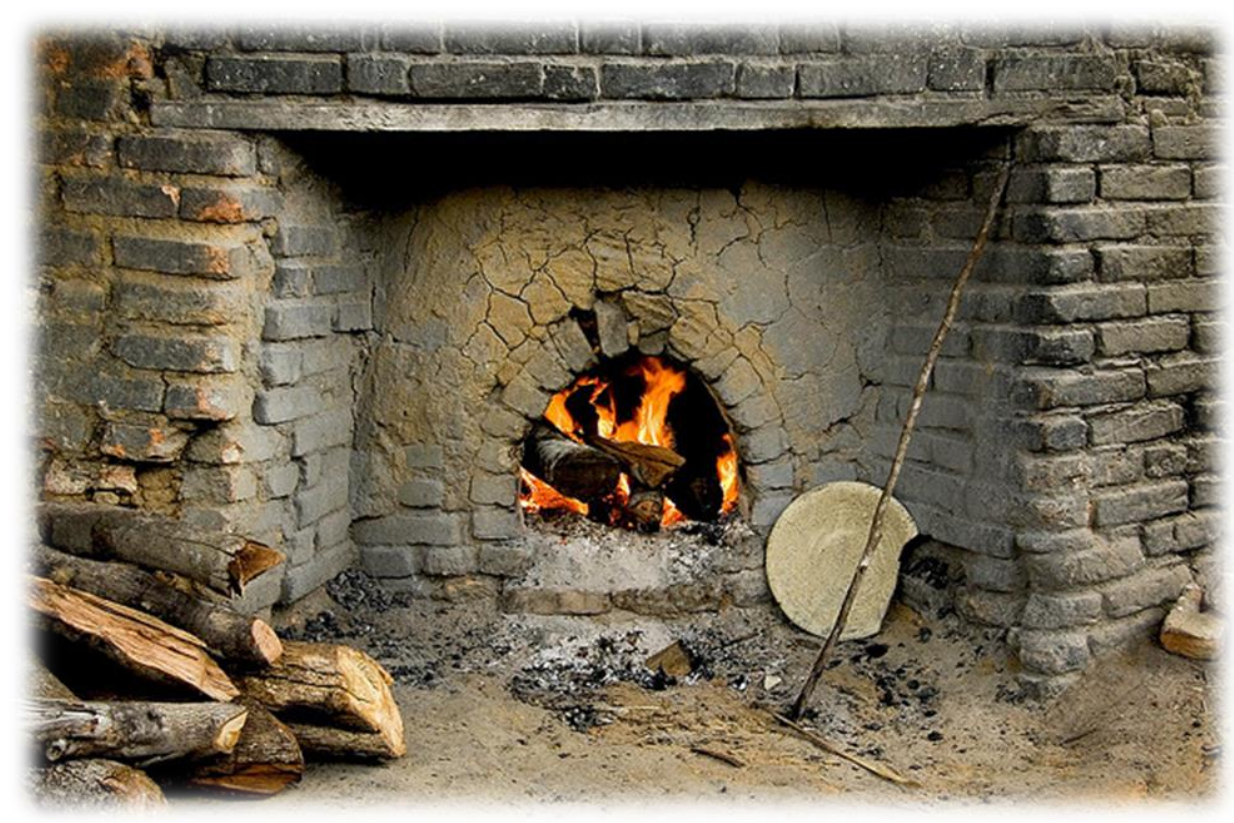

Queima em forno caieira 
A lenha utilizada para as queimas é retirada na região. Há um terreno atrás da igreja com livre acesso para a retirada de lenha, mantido pela associação AAMOM (Associação de Ajuda Mútua dos Oleiros de Maragogipinho). Nesse terreno, são plantadas árvores nativas para abastecerem as olarias. Os oficiais também compram lenha de atravessadores.

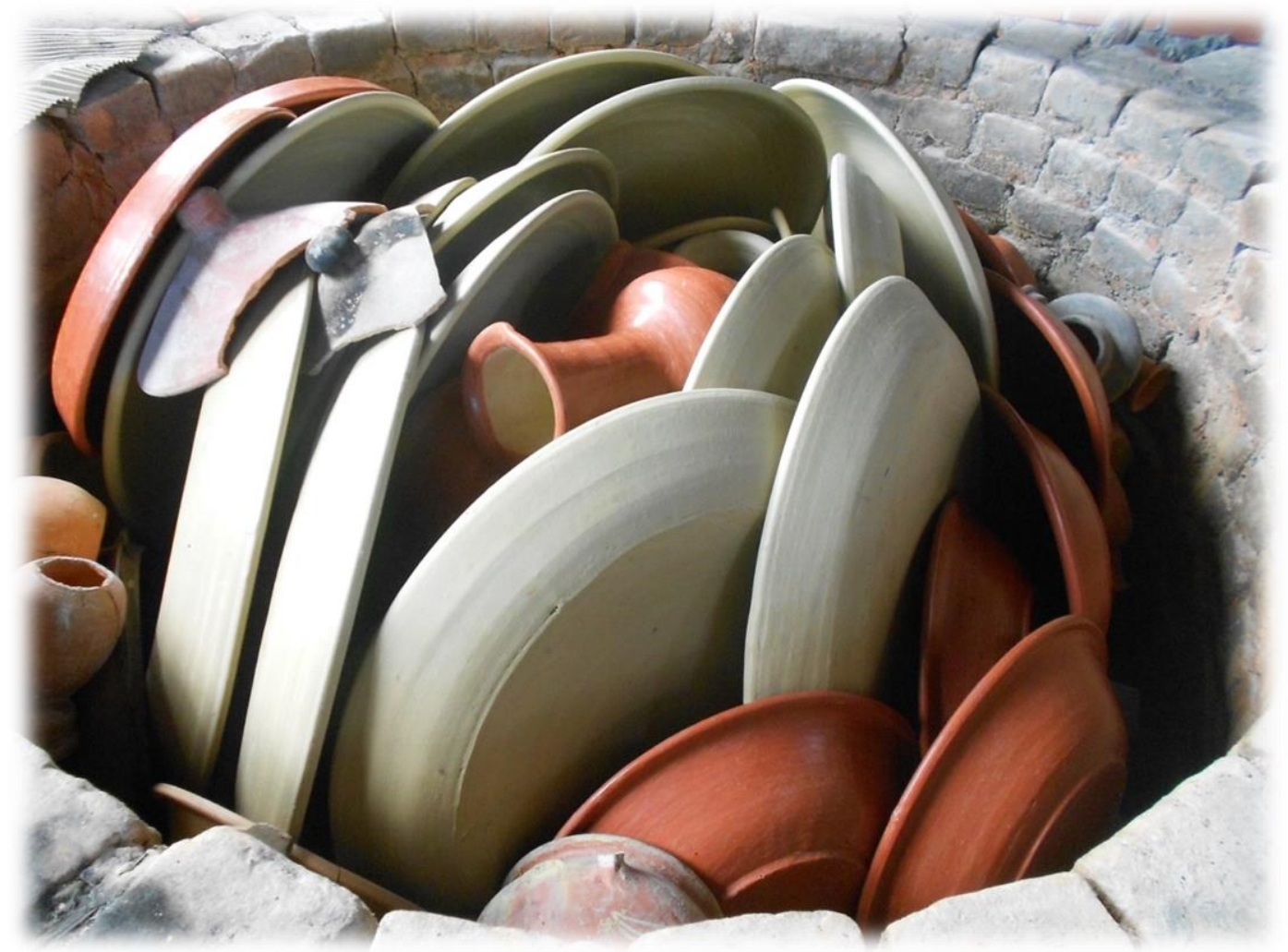

Arrumação do forno caieira 


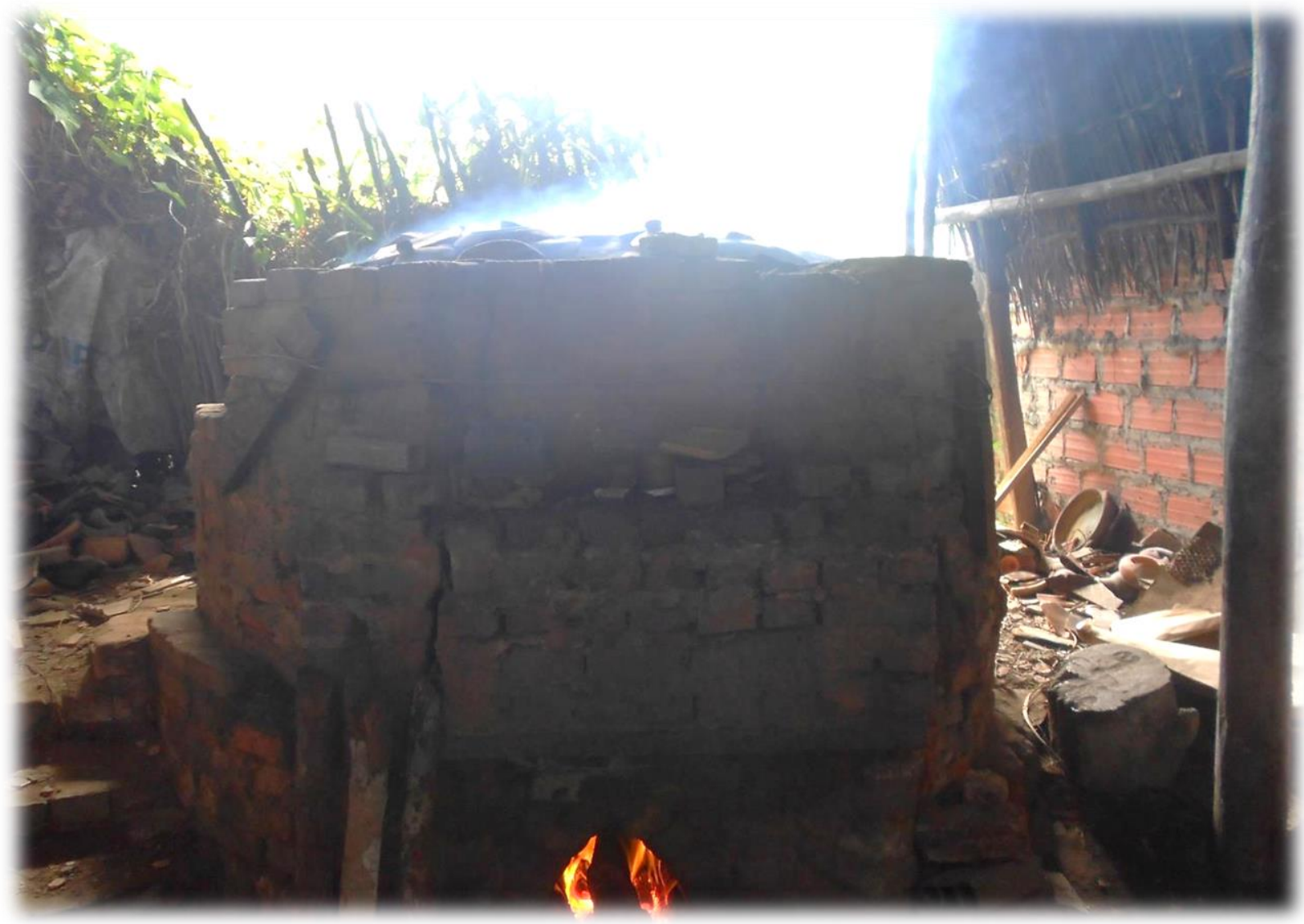

\section{Queima no forno caieira}




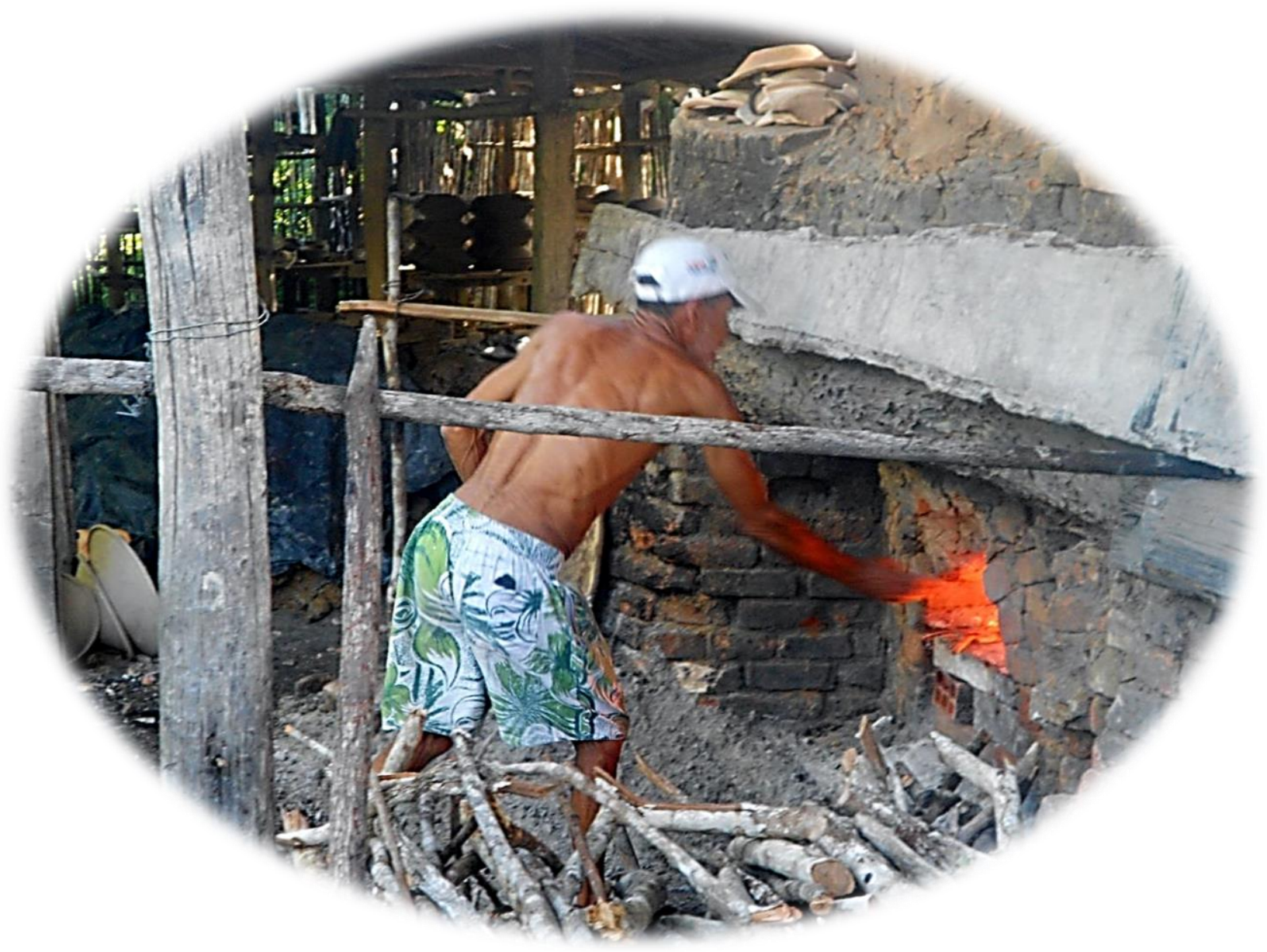

Queimador Jorge dos Santos alimentando forno caieira 
Um dos fatores importantes para uma boa queima é o esquente, período em que as peças recebem calor de forma gradativa para perderem a umidade que lhes resta. Sem um bom esquente, os objetos podem estourar durante a queima. No forno maior, de capela, o esquente demora em torno de oito a dez horas, enquanto a queima propriamente dita dura de duas a três horas, informou Nené. No forno menor, o caieira, o esquente dura mais ou menos quatro horas e a queima de quarenta a sessenta minutos.

A queima é feita pelo queimador ou pelo oleiro. Ele deve permanecer o tempo todo ao lado do forno, alimentando o fogo até atingir a temperatura almejada. Nené calcula que, em queimas corriqueiras, o forno de capela alcance de 400 a 500 graus e o forno caieira de 250 a 300 graus. Se a queima for para objetos vidrados, o forno pode atingir até mil graus. Não há medidores de temperatura. Os sinais de que as peças estão prontas vêm da cor que o barro adquire, vista pelos suspiros do forno de capela e pelos cacos colocados em cima das peças no forno caieira. Padre me explicou que o barro vai clareando:

Tem que ficar na observação. Vai clareando, vai vendo do lado. Se tá escuro ainda, mas não alvejou direito, vai jogando lenha, jogando, jogando. Aí, quando começa a clarear a gente vai parando, não pode jogar a mais. Se jogar a mais, o que vai acontecer? Vai torrar o forno. Se 
queimar demais, a peça fica toda alinhada. Não é quebrar. O som fica bom, mas ela fica toda com aquelas veiazinhas (Padre).

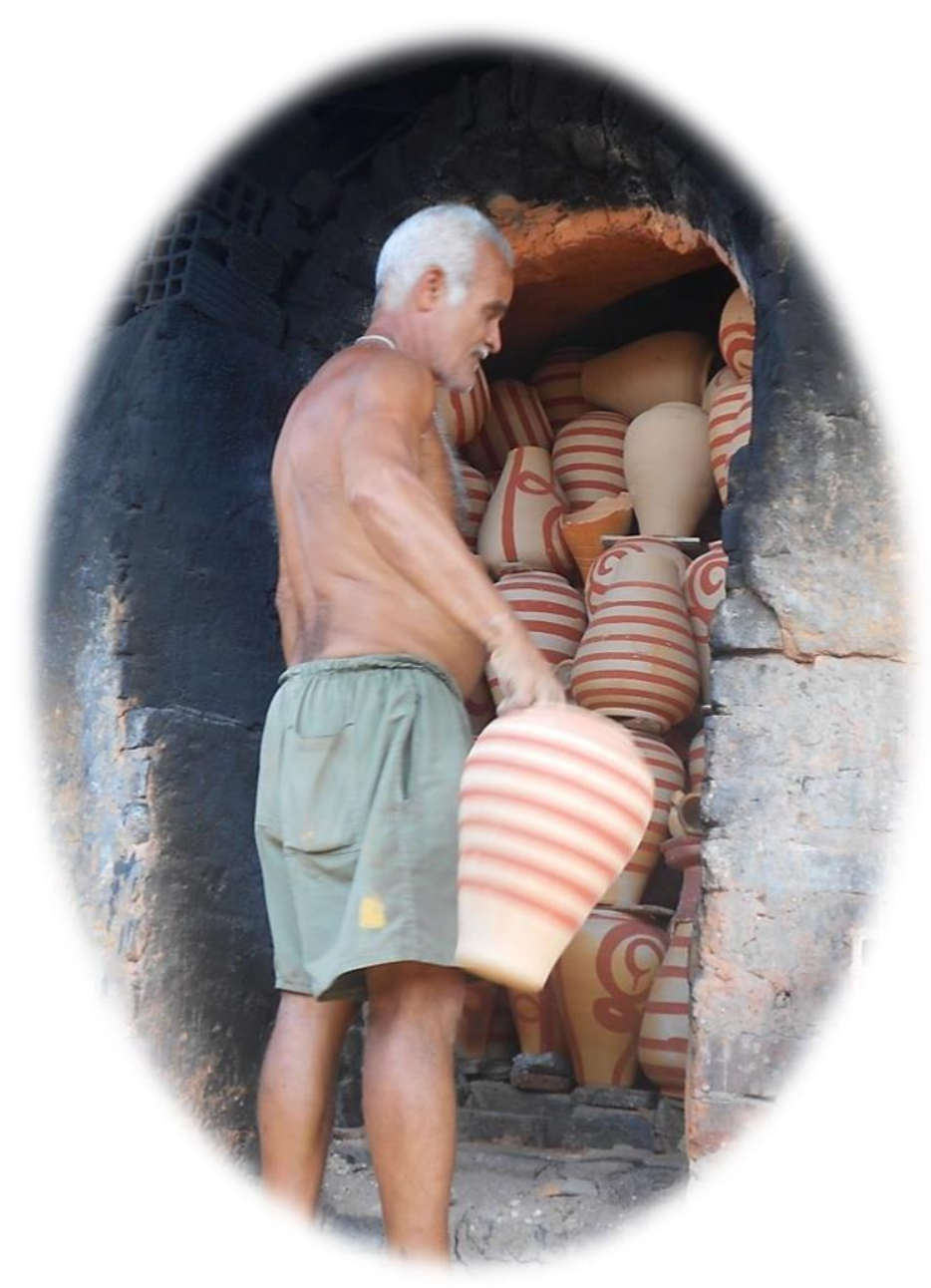

Oleiro Dilton Duarte desenfornando forno de capela 
Depois da queima, o forno permanece fechado durante várias horas, antes de ser aberto, para o esfriamento das peças. No forno de capela, os objetos demoram até três dias para esfriarem e serem retirados. Os utensílios são desenfornados numa temperatura morna.

\subsubsection{Vitrificação}

Um processo de queima bastante utilizado pelos oleiros é o da vitrificação. Nele, as peças recebem duas queimas. A primeira queima, chamada de biscoito, é realizada em baixa temperatura, a mais ou menos 300 graus. Após esse cozimento inicial e o esfriamento, é passada uma mistura de chumbo com lamugem (argila mole) e a peça é enfornada novamente, dessa vez em temperatura bem mais alta: de 800 a 1000 graus. O resultado é uma superfície esmaltada, com brilho, impermeável à água.

A vitrificação é comumente utilizada em panelas e pratos que depois podem ir ao fogão a gás. O chumbo é um metal tóxico, que produz danos à saúde humana. $\mathrm{A}$ prática tem mais de duzentos anos e a maioria dos artesãos sabe desses perigos. 
Padre não faz louça vidrada. Mas seu pai produzia:

Meu pai trabalhava com louça vidrada, louça esmaltada, que tem chumbo. Meu pai trabalhou muito com aquilo. Mas eu disse: "eu não vou trabalhar com óxido de chumbo". Não sei, a ciência já evoluiu toda. Eles dizem que todo material pesado é ruim pro estômago. Meu pai trabalhou muito.

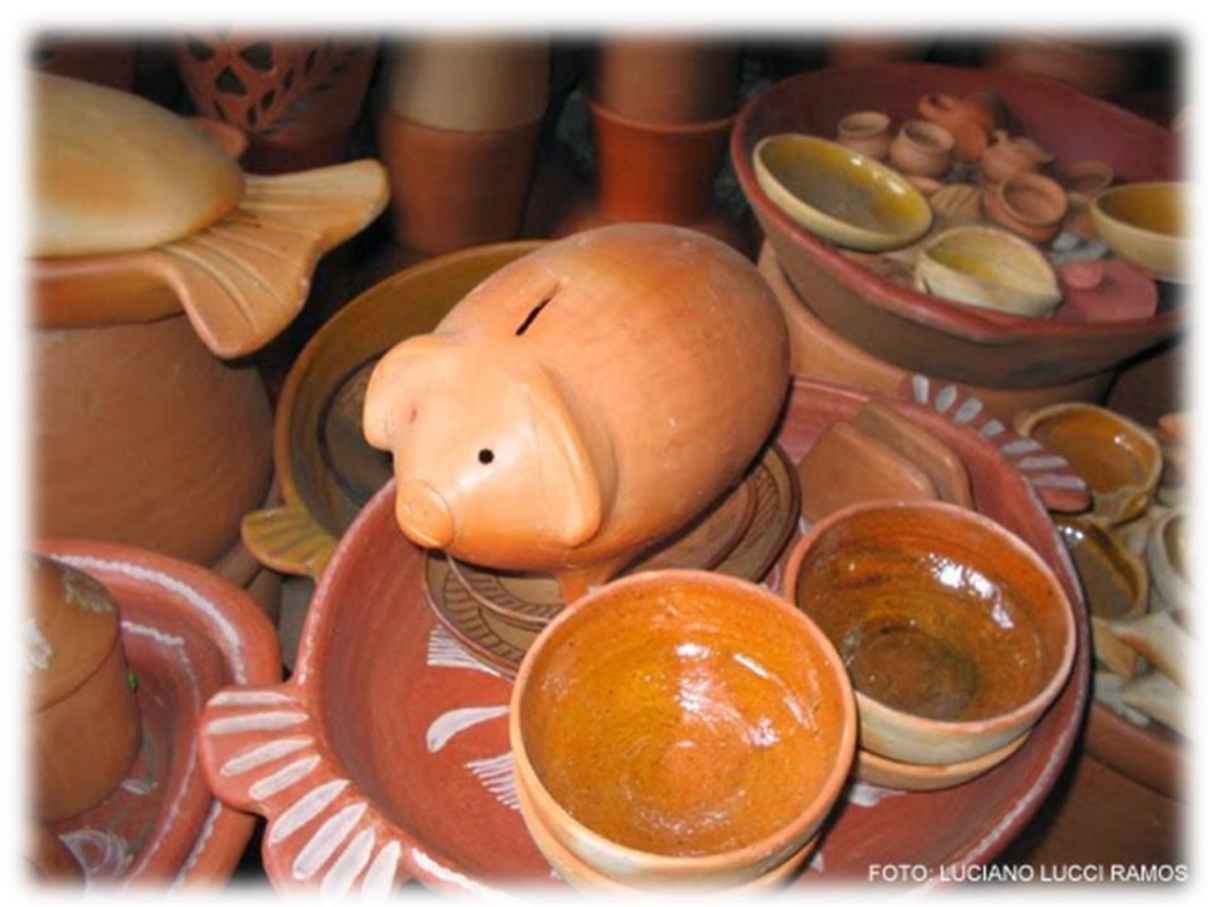

Pratos vitrificados

(Foto: Luciano Lucci Ramos) 


\subsubsection{Comercialização das peças}

A sobrevivência econômica dos artesãos de Maragogipinho depende dos insumos inconstantes de políticas públicas, da comercialização da cerâmica para particulares e, sobretudo, das vendas em feiras permanentes e esporádicas.

A tradicional Feira dos Caxixis que ocorre uma vez ao ano, na semana santa, de quinta-feira a domingo representa uma boa oportunidade para que o próprio artesão comercialize sua produção, sem atravessadores. Em Maragogipinho, homens e mulheres se revezam para a venda durante os quatro dias que dura a feira.

Nelinho diz que a Feira dos Caxixis não é tão lucrativa assim:

Essa Feira do Caxixi tem uma concorrência estúpida. (...) este é um período de baixa estação, ninguém compra nada. Baixa estação, então, é um período em que a gente corre atrás de uma graninha porque, como eu te falei, o que a gente faz aqui dá só para manutenção nossa, a gente não ganha pra juntar dinheiro, pra ter um caixa extra, aquela coisa, a gente não ganha dinheiro pra isso. Então, aí é oportunidade. A Feira do Caxixi é uma feira que, mesmo não vendendo, é uma feira que vende. 
Nesta feira se ele diz: "Pô, a feira deu péssimo!", a gente sabe que, em compensação, rolou alguma graninha que dá para, quando nada, manter a semana dele.

Já o Mercado de São Joaquim, em Salvador, é para onde escoa de forma permanente a maior parte da produção cerâmica de Maragogipinho. Alguns produtores possuem locais estáveis no mercado, porém é ampla a atuação dos comerciantes, o que contribui em alto grau para desvalorizar as peças, pois pagam aos artesãos baixos preços pelos objetos. Outros aspectos que desvalorizam as peças são o fato de as atuais cerâmicas conservarem pouco a pintura com o tauá e a tabatinga e a exposição das peças ser feita de forma descuidada, comumente são "jogadas” no chão do mercado.

Um fator de peso para a degradação da cerâmica de Maragogipinho, na opinião de Nelinho, é que, de uns anos para cá, se intensificou a migração procedente de outras regiões do estado. Os recém-chegados logo vão se engajando na produção da cerâmica como ajudantes, muitas vezes até constituindo suas próprias olarias na periferia, onde a produção passou a se concentrar nos cofres-porquinhos.

De primeiro, Maragogipinho era formado só de pessoas nativas. Hoje não. Hoje, existe um pessoal clandestino que veio de fora, que se 
infiltrou no trabalho, que produz e não conhece as raízes de como começou isto, do valor que isto tem pra o lugar, certo? E aí essas pessoas não procuram fazer um produto de qualidade, fazem um produto sem qualidade... Hoje mesmo, eu não coloco nem mais uma peça pra São Joaquim. São Joaquim era uma vitrine de Maragogipinho. Hoje, se você chega a São Joaquim é horrível. São Joaquim era uma vitrine, porque a gente fazia essas peças que são vermelho e branco: com tauá e tabatinga (Nelinho).

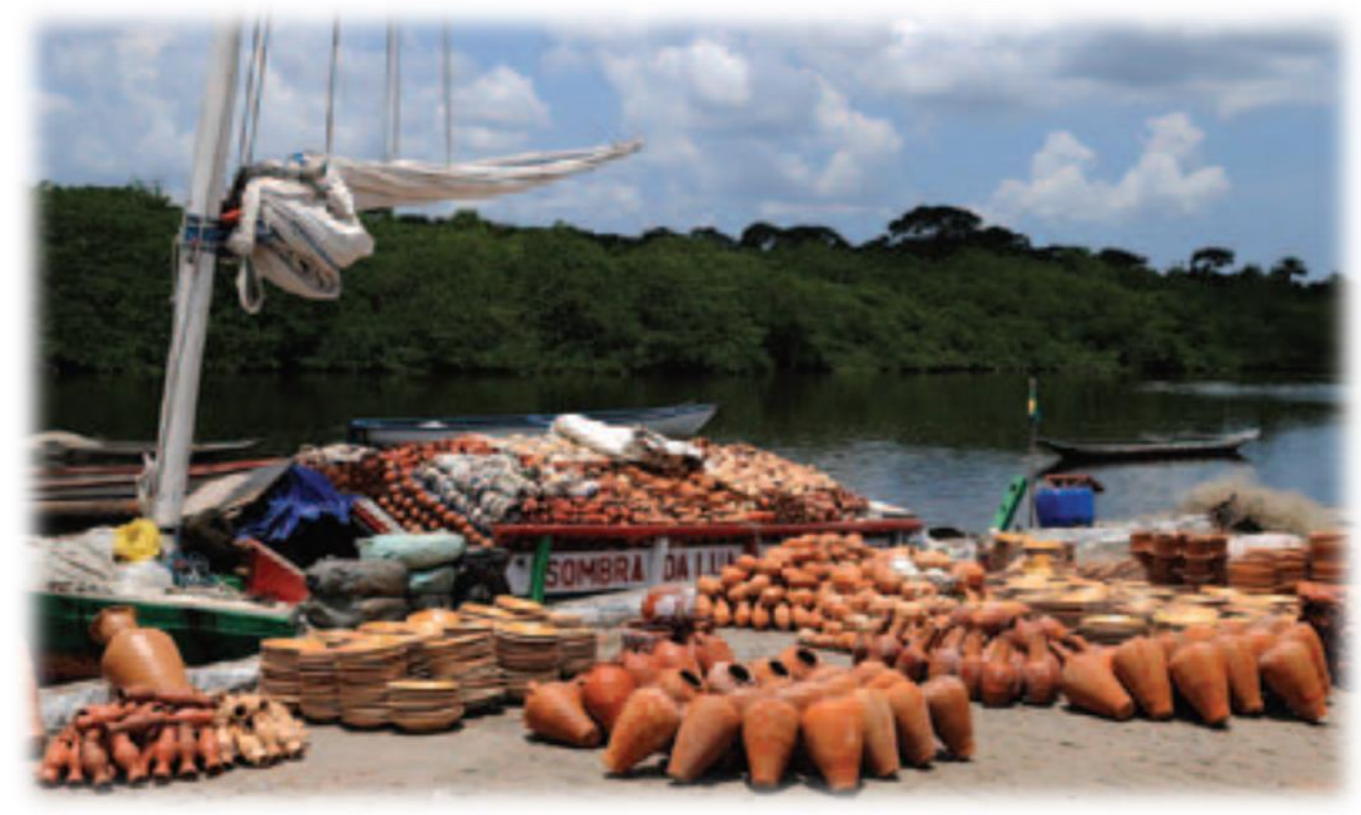

Peças no cais esperando pelo transporte

(Ferraz, 2009, p. 26) 
O transporte das cerâmicas para lojistas de outros centros e para atender a encomendas particulares das olarias representa um problema crucial e ainda insolúvel no escoamento da produção. Até há bem pouco tempo, a mercadoria destinada a Salvador era transportada pelos saveiros. Esse tipo de embarcação é bem antigo e foi tombado pelo governo estadual. Hoje, vem sendo feito exclusivamente por terra, através de camionetes e caminhões. O custo do transporte, tanto fluvial como terrestre, é caro e é de responsabilidade exclusiva do artesão, não há subsídio para ele.

Houve uma tentativa da AAMOM para obtenção de um caminhão junto à administração municipal de Aratuípe. O projeto foi aprovado, mas o caminhão nunca operou. Conforme Ferraz (2009, p. 16), uma caçamba fora doada à entidade para o deslocamento do barro das jazidas aos produtores, contudo, só atendia aos oleiros nos finais de semana, exatamente no seu período de descanso, o que gerou grande insatisfação entre as pessoas da comunidade. Quando comenta os efeitos desses entraves, Nelinho vai direto ao ponto:

Eu vejo assim: Maragogipinho é considerado o maior centro cerâmico da América Latina, isto já foi pesquisado e já foi dito: aqui é o maior centro cerâmico da América Latina. Mas é esquecido. É esquecido pela 
prefeitura, pelo município, isto aqui é esquecido pelo governo e por tudo. Porque se a gente aqui, talvez, tivesse uma maneira melhor pra se trabalhar, e para que não deixassem os jovens saírem pra procurar trabalho fora, certo? Vai chegar um ponto que isto aqui vai ficar sem trabalho.

Em 2013, a Associação agenciou um contrato de venda com a loja Tok\&Stok, que atualmente continua ativo. No entanto, o problema do transporte não foi amenizado, continuou na alçada dos artesãos e, pior, à responsabilidade pelo transporte das peças foram acrescidas outras tarefas burocráticas que lhes oneram: compra de plástico-bolha, de etiquetas e tags, preparação de embalagens, enfim, tarefas que nada têm a ver com a natureza do seu trabalho.

O menino que estava vendendo para a Tok\&Stok tinha que entregar em Salvador. Entregava de carro mesmo, às vezes, ia de Kombi ou de caminhonete. (...) Porque quem vende para a Tok\&Stok é a associação, só que da maneira que a loja quer, eu nem fiz questão de trabalhar com eles. Porque, veja bem, a gente aqui é artesão, a gente não é empresário. O que acontece: a gente tinha que comprar código de barra, etiqueta, tag, embalagem, isso, aquilo e aquilo outro, certo? Tudo para repassar no valor do produto. Mas a gente é que tem que investir, a gente tem que estar buscando empresa, o código de barra estava sendo 
feito por uma empresa lá de Santa Catarina, a outra estava sendo feita por uma empresa de São Paulo e isso é complicado. A gente é artesão, a gente não tem tempo para estar manipulando coisa de empresa (Nelinho).

De tempos em tempos, órgãos federais e estaduais investem em programas de incentivo aos artesãos. Ao longo de anos, a Bahiatursa promoveu várias feiras e exposições da cerâmica de Maragogipinho. O Instituto Mauá realizou diversas aquisições diretamente com os artesãos e eles passavam períodos extensos produzindo para a instituição. No entanto, essas compras sempre ocorreram de maneira inconstante e irregular, provocando insegurança nos produtores:

Quando eu era garoto, o Mauá comprava aqui duas, três, quatro vezes, ou mais. Ele comprava o produto, ele levava, ele vendia o produto na loja, tinha uma loja ali na Barra e tem outra no Pelourinho. Então, ele vendia colocando só uma porcentagem, que era pequena, vendia o produto quase que no mesmo preço da gente. O Mauá chegava aqui, comprava na mão da gente e o próprio comprador do Mauá já vinha pagando todo mundo, em dinheiro. Depois passou um tempo em que o Mauá esquecia que a gente existia aqui, levava meses e meses para a gente receber esse dinheiro... Hoje, o Mauá compra, paga com 30 dias, mas acho que ele só compra uma vez, de dez em dez anos (Nelinho). 
Recentemente o Instituto Mauá foi extinto pelo Governo do Estado da Bahia. Em Maragogipinho, a extinção desse órgão que os amparava significativamente foi bastante comentada e lamentada pelos artesãos. As políticas públicas se mostram cada vez mais instáveis no atual modelo de civilização urbano-industrial disseminado pelo planeta. A globalização gerou uma crise contemporânea que coloca em cheque valores essenciais desses povos, gente que sempre ganhou o sustento com o trabalho de suas mãos. 
Quanto ao oleiro, esse leva vividos anos mais do que suficientes para saber que a melhor maneira de fazer morrer uma rosa é abri-la à força, quando ainda não passa de uma pequena promessa em botão. Saramago, 2000, p. 110. 


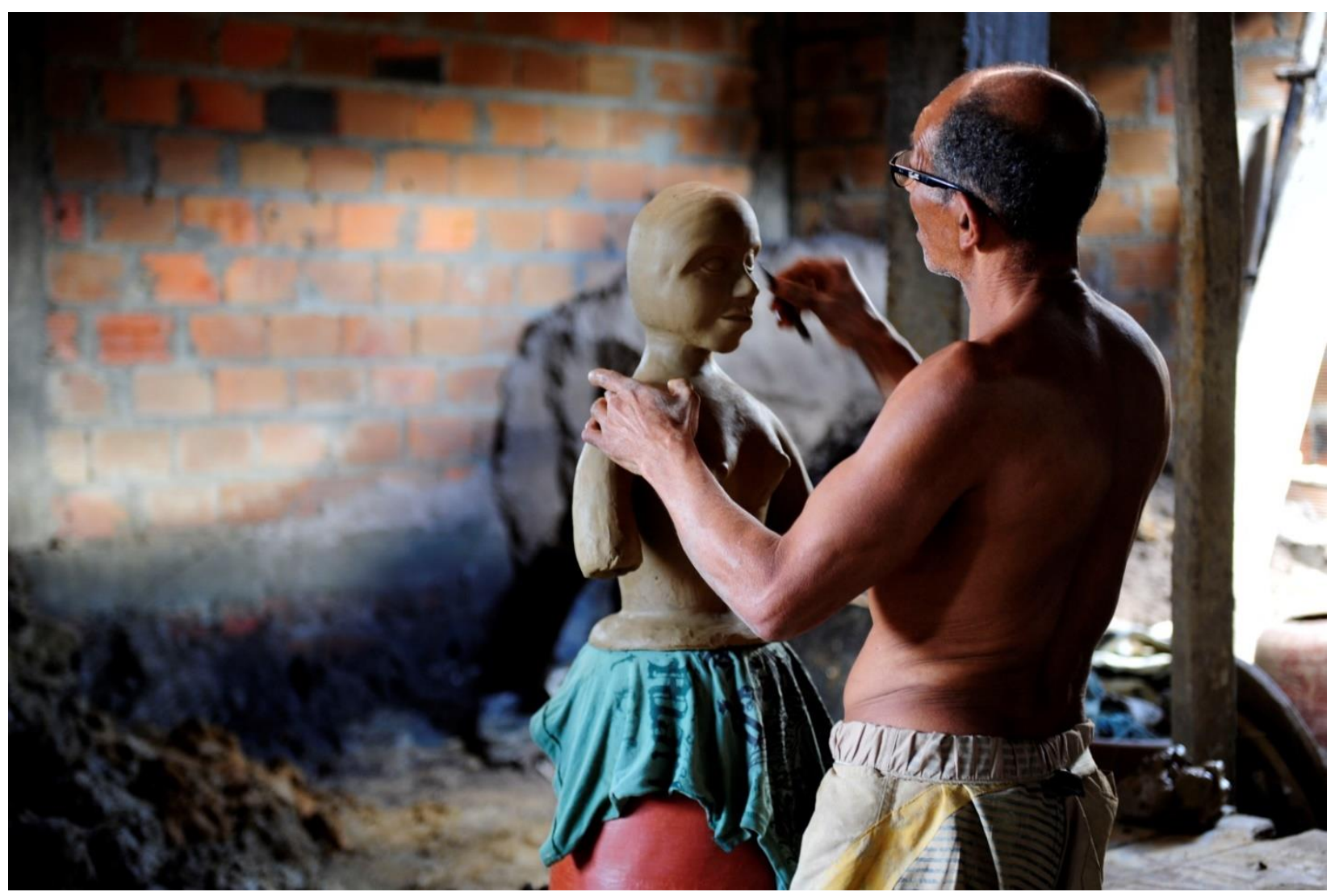

Mestre Seu Zé modelando uma baiana

(https://farm4.staticflickr.com/3733/9579760662_ecc3e6058b_o.jpg) 


\section{VOZES DOS MESTRES}

Os artesãos são os verdadeiros professores de uma educação de classe

e, quando se educam a si próprios com a prática de que são parte, fazem avançar a cultura e a consciência de que são os guias.

Carlos Rodrigues Brandão

\subsection{Maestria}

Em comunidades tradicionais, a maestria não requer diplomas nem certificados. Sua legitimação se faz no cotidiano, no tempo, no seio da história oral. O mestre ou mestra é geralmente uma pessoa mais velha, que exerce o ofício artesanal há bastante tempo. Como inicia a atividade em tenra idade, na maturidade já possui significativo conhecimento, represa em si práticas ancestrais. Outra qualidade do mestre é que faz seu trabalho com prazer e esmero.

Pode-se vir a ser mestre sem o ter desejado ou procurado. "A afirmação do poder do mestre inscreve-se numa hierarquia ontológica, fora de qualquer sanção 
administrativa", elucida Gusdorf (2003, p. 103). O mestre assume uma responsabilidade não somente material e intelectual, mas também espiritual. Do mestre, emanam dignidade e sapiência:

Tornamo-nos mestres no dia em que descobrimos que já não há mestres. Houve, é certo, heróis, pensadores, gênios e santos. Mas apesar de suas auréolas, aparecem como homens que, longe de possuírem a verdade, lutaram pela verdade, ou melhor, contra ela. Fizeram o que puderam, cada um por seu lado. E essa partida que travaram até o fim, sem saber se a ganharam ou perderam, é que é preciso hoje voltar a travá-la, cada um para si, numa certeza idêntica. Esse é o debate de todo mestre, em que cada um está em jogo. Vemos facilmente que a relação com o discípulo permanece exterior a esse afrontamento, a essa luta com o anjo da verdade, de que o herói solitário pouco falará, mesmo ao aluno mais amado, porque a palavra não tem alcance sobre essa realidade íntima de um destino em gestação, em vocação, cujos inícios e termos se perdem na penumbra, para lá dos confins do discurso (idem, ibidem).

O trabalho e os ensinamentos do mestre artesão congregam valores e signos da cultura a que pertence. 0 mestre detém, socializa e recria saberes que trespassam gerações, unifica em seu fazer artesanal a identidade social de seu povo. Além de 
possuir elevada destreza manual e disciplina, é um profundo conhecedor do meio onde vive.

Acima de tudo, o mestre artesão é um criador. Ao reproduzir incessantemente práticas ancestrais, exerce seu fluxo criativo individual, mantendo conexão direta com sua comunidade. $\mathrm{O}$ mestre dá forma a ideias e a expectativas que, mesmo coletivas, recebem sua marca pessoal. Os objetos que produz não são singulares, mas jamais idênticos a outros criados com a mesma finalidade.

A confirmação do mestre artesão reside num conjunto de saberes e fazeres que não necessariamente é uno, padronizado. Cada indivíduo se destaca pelo que tem de mais evidente e se afirma a partir dessas potencialidades. Tais saberes não se ordenam numa hierarquia de importância; são competências que de acordo com o contexto impactam de maneira distinta nas relações interpessoais, interorganizacionais e produtivas. Os saberes potencializados de cada mestre se distinguem um do outro e isso não lhes descredencia o mérito do reconhecimento, da afirmação social. Como característica peculiar está o sentimento de pertencimento, de integralidade no ser-fazer, no compromisso de manter viva a chama da tradição com iniciativa de neófitos (Nascimento, 2012, p. 88). 
O que sucede entre mestre e discípulo é mais do que o ensino das técnicas entre pessoas da mesma família. Saber tornear ou pintar bem, construir um estilo ou traço próprio constituem fatores que dependem do grau de aproximação e da afinidade com o mestre - seja ele um parente consanguíneo ou não. O aprendiz não aprende somente como tornear ou pintar um objeto, para além disso, aprende a relacionar-se com a peça artesanal por meio da posse de um repertório, cuja partilha de saber implica uma tomada de consciência de seu modo de ser e de estar no mundo.

Na cultura quéchua, a figura do mestre é conhecida como amauta. O amauta, ele próprio, já é o ensinamento, a maneira como vive, como se relaciona com o mundo e com a comunidade. A ação do mestre é pautada pela busca de coerência. Os mestres artesãos do barro atuam como amautas em suas comunidades. Gentis e generosos, são pessoas cuja integridade se evidencia como referência porque se constituíram a partir de uma inexorável dívida com a tradição. Esse é o verdadeiro legado que partilham com seus aprendizes, que não se restringe meramente a ensinar uma técnica.

Em Maragogipinho, vários artesãos e artesãs são reconhecidos e legitimados como mestres pelos seus pares. Quando conversei sobre maestria, ouvi com frequência 
os nomes de Vitorino, Padre, Nené, Almerentino, Nelinho, Miro, Zé Curu, Seu Zé, assim como Rosalina, Santa e Zelita. Cada uma dessas pessoas se destaca por um conjunto de saberes e modos de ser e se afirma a partir dessas potencialidades. No povoado, vários oleiros e pintoras aprenderam seu ofício com esses mestres e mestras.

\subsection{Repetição: a força motriz}

O fazer artesanal é repetitivo. São também repetitivos o ensino e a aprendizagem do artesanato. "A repetição torna-se o elo de todos os instantes" (Frade, 2006, p. 44). Repetir infinitas vezes o mesmo gestual sobre a matéria barro não acarreta, absolutamente, em um adestramento. Ao contrário, a repetição incansável proporciona um estado de transcendência, a entrega de um corpo que, em seu fazer estético, pensa através da forma.

Quando perguntei a Nené se não enjoava de repetir diariamente os mesmos gestos e plasmar no barro as mesmas formas, negou enfaticamente, disse-me que, quando está trabalhando no torno, sua mente esvazia-se: 
Se eu estiver trabalhando sozinho, sem ninguém para conversar, esqueço de tudo, fico ligado somente no barro. Podem passar dez pessoas que eu nem vejo. (...) Problema, todo mundo tem. Mas quando se está ali, se esquece, dá um branco na gente, a gente fica ligado somente naquilo.

O gestual repetitivo proporciona uma imersão profunda, apartada da busca pela originalidade. De certo, originalidade não é uma palavra de relevo em Maragogipinho. Entre os oleiros e as pintoras não há uma preocupação explícita em criar objetos originais. Assim como seus pais, avôs e bisavôs seguem reproduzindo modos de produção convencionais. "Na matéria barro a gente não inventa nada, a gente copia. Tudo já fizeram!", afirmou Nené. Questionei-Ihe se há momentos em que gosta de inventar alguma coisa no torno. Respondeu-me que raramente tem essa vontade e quando, certa vez, se empenhou, efetivamente, em criar uma peça inédita, veio a descobrir depois que já a haviam inventado:

Eu fiz, numa ocasião... A peça tá até ali. Eu fiz uma moringa sem fundo, pra botar água. Algo que me deu, assim, na cabeça: 'vou fazer uma moringa sem fundo'. A senhora sabe que essa moringa já tinha sido inventada? Eu vi depois pela internet. Ela já existia. Pra mim, eu achei que tinha criado essa peça, mas não foi, ela já existe (Nené). 

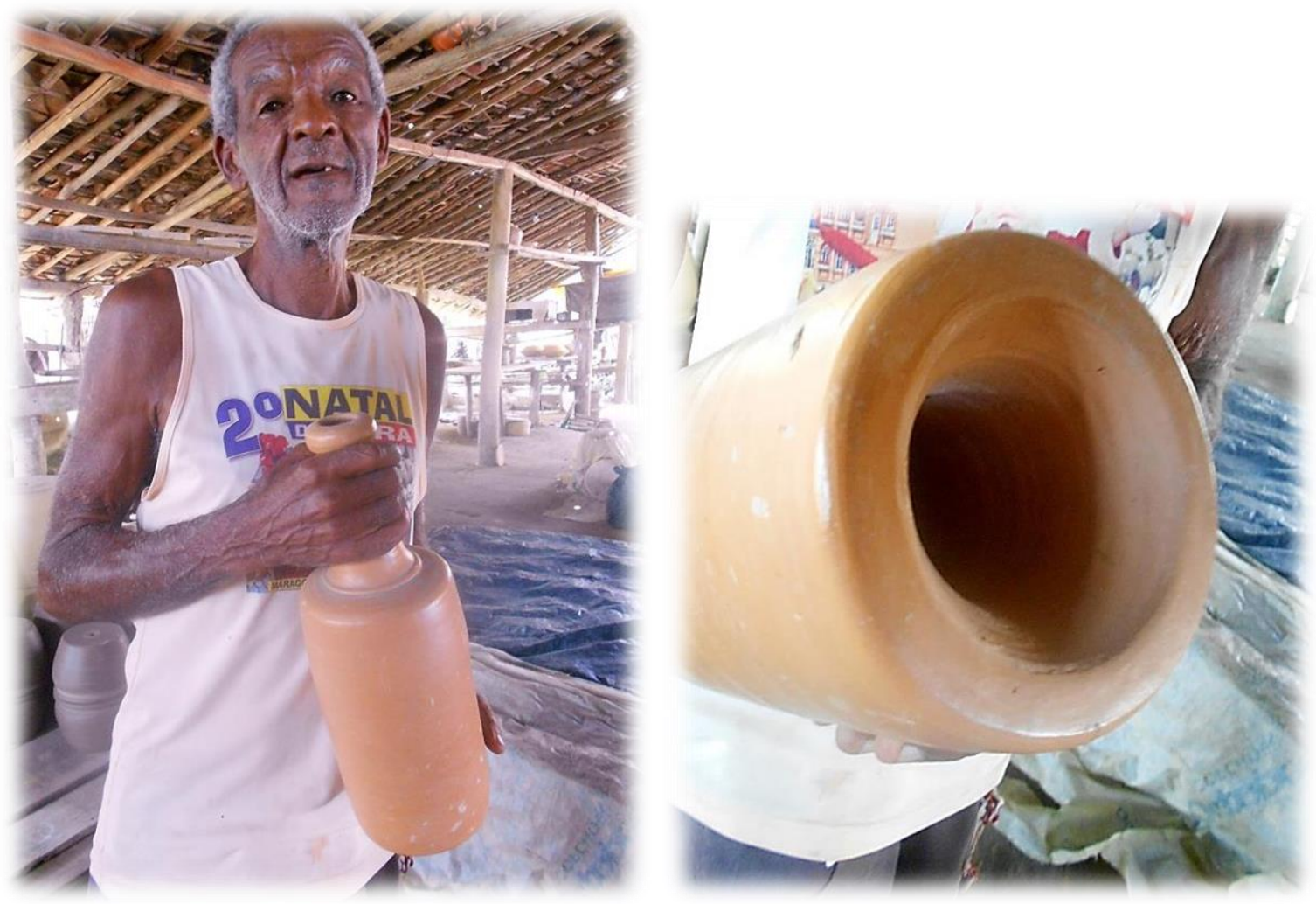

Nené com sua moringa sem fundo

Por meio da repetição e, consequentemente, do domínio da técnica, o mestre alcança a maturidade e consolida um estilo. Esse processo é contrário ao que ocorre nas sociedades que valorizam a arte como expressão individual, em que a 
busca pela novidade calcada em uma estética que incentiva a mudança acaba por negar a tradição:

Pode-se dizer que enquanto nas sociedades unânimes há variedade na semelhança, nas sociedades individualistas há uma uniformidade em toda a variedade (Coomaraswamy, 2001, p.38).

Na China, por exemplo, a originalidade não constitui um valor estético porque o artista atua como participante no processo da criação universal. A tarefa suprema do artista consiste em captar o dinamismo interno da criação cósmica, o Qi, e injetá-lo na sua obra. Leys (1998, p. 195) esclarece que Qi significa "sopro", "energia", etimologicamente o termo designa o vapor do arroz ao ser cozido. Na medida em que é capaz de animar a obra com esse sopro universal, a expressão do artista reproduz a expressão do criador universal. A manifestação do Qi, portanto, ocupa um papel privilegiado na arte chinesa. O que importa é se o artista consegue transmitir o Qi. O meio formal pode tanto ser inédito, como tomado de empréstimo. Em última instância, uma cópia pode até ultrapassar o seu modelo se conseguir mostrar melhor o influxo do Qi.

Um bom exemplo disso, demonstra Leys, encontra-se na caligrafia, que é considerada na China como a arte suprema do pincel. A caligrafia incorpora uma 
linguagem artística estritamente governada pelas convenções formais e técnicas, que quase não dá espaço à iniciativa criativa do artista, mas que mesmo assim expressa a sua personalidade:

Não só não é permitido ao calígrafo inventar a forma de um único caractere, mas ainda o número de pinceladas, e mesmo a orientação e a ordem exata segundo as quais estas diversas pinceladas devem sucederse, são rigorosamente pré-determinados. Ao mesmo tempo, a caligrafia é também a arte que pode permitir a um indivíduo expressar mais diretamente, mais liricamente, a sua personalidade própria, o seu temperamento singular e mesmo os matizes íntimos e sutis da sua sensibilidade (Idem, p. 200).

Dentro desta perspectiva, o plágio constitui a cópia de formas extrínsecas, que verdadeiramente não são do autor, não Ihe pertencem, explica Coomaraswamy (2001, p. 36). O plagiário é aquele que faz de um estilo seu amo - a exemplo das construções administrativas de nossa época, de arquitetura greco-romana - e não aquele que persegue "fins fixos" (aspas do autor). O artista ocidental contemporâneo quando recorre à tradição, comumente busca-a fora de sua cultura, na arte dos povos primitivos ou de outras civilizações. 
Marijose Pinto, artesã e presidente da AAMOM, relata que uma pesquisa descobriu que no povoado há mais de cinco mil peças diferentes, porém, segundo ela, muitas pessoas se restringem ao plágio, a copiar formas que não lhes pertencem. Diferentemente de Nené, ela se preocupa em produzir peças únicas.

Aqui é assim: hoje surge uma peça nova e logo eles procuram copiar aquela peça. Não botam a mente para funcionar, para idealizar peças novas. Eu sempre procurei fazer alguma coisa diferente para que, na verdade, dificultasse e não facilitasse [o plágio]. Eu trabalho com tudo um pouco, com a linha tradicional também, mas procurei me diferenciar. (...) As minhas esculturas seguem essa linha, por mais que alguém tente se aproximar daquilo que eu faço, não vai conseguir. Até porque são peças únicas (Marijose).

A discussão sobre plágio é complexa e não a aprofundaremos nesta pesquisa. 0 que nos interessa extrair do tema é o lugar que ocupa a imitação no processo de ensino e aprendizagem artístico. Observar e imitar o modo de fazer do mestre constituem duas capacidades básicas no aprendizado do artesanato. A imitação, mais do que um recurso no processo de ensino e aprendizagem, viabiliza a apropriação de uma linguagem e o desenvolvimento de um traço pessoal. Não se 
imita somente a forma externa, também se imita o conteúdo, o que contribui na manutenção e na continuação da cultura.

Ao imitar, o aprendiz não executa uma cópia mecânica do mestre. A imitação, portanto, não se reduz à mera reprodução, pois, quando imita, o imitador mobiliza as referências culturais que traz consigo e que sustentam o estabelecimento de novas associações e novas combinações, de acordo com interesses e necessidades. Nesse sentido, existe uma unidade dialética entre imitação e criação. Nelinho explica que, no início, quando aprendeu a tornear com o pai, imitava e repetia incansavelmente cada peça com os mesmos gestos do professor. Mais tarde é que foi desenvolver uma maneira própria de trabalhar o barro:

Eu aprendi a trabalhar muito do jeito dele [o pai]. Ele fazia e eu fazia, então eu cheguei a um ponto de fazer as peças de um jeito tão igual a ele que só eu e ele sabíamos qual era a minha e qual era a dele. (...). Hoje eu não gosto muito do risquinho certo, mas na época dele eu tinha que fazer aquele risquinho bem certinho.

Em meu processo de aprendizado com o barro, descobri que a criatividade habita os interstícios da repetição. Quando comecei a frequentar aulas de cerâmica, tinha predileção por produzir esculturas, pois buscava um caminho criativo ligado à 
originalidade, ao que eu, então, concebia como arte. Tinha preconceito com a repetição e com as formas utilitárias. Foi o torno que me cativou e revelou que o território da arte transcende esses paradigmas. O movimento do torno é exaustivamente repetitivo, ele gira, gira e gira. As formas que produz, por um ponto de vista, podem também ser consideradas análogas, todas arredondadas. Contudo, de tanto repetir formas arredondadas, descortinei alguns segredos desses objetos-continentes, de alguma forma percorri o anel que une utilidade e beleza, ampliei meu entendimento da arte.

O desenvolvimento das habilidades artísticas depende da maneira como é organizada a repetição, afirma Sennett, pois à medida que desenvolvemos nossa capacitação, mudamos o conteúdo daquilo que repetimos:

A educação moderna evita o aprendizado repetitivo, considerando que pode ser embotador. Temeroso de entediar as crianças, ávido por apresentar estímulos diferentes, o professor esclarecido pode evitar a rotina, mas desse modo impede que as crianças tenham a experiência de estudar a própria prática e modulá-la de dentro para fora (Sennett, 2008, p. 49). 
"Fazer algo repetidas vezes é estimulante quando se olha para frente" (idem, p. 196). A recompensa do fazer de novo se projeta para o futuro, muitas vezes para um novo trabalho:

Às vezes eu estou confeccionando uma peça, mas meu pensamento está em outra, em fazer outra peça, eu tenho que fazer alguma coisa ali, vamos ver se vai dar certo (Nelinho).

$\mathrm{Na}$ repetição, mora o prazer do enfrentamento entre mão e matéria. Na construção incessante de bolas, ovos, pratos, tigelas, xícaras, garrafas fui me apropriando da técnica, movida pelos fios que estimulam concomitantemente a imaginação da matéria barro e as forças da mão, enfim, os devaneios da vontade, parafraseando Bachelard (2001).

O oleiro Vitorino, de 95 anos, me explicou que o fato de repetir formas não o impedia de inventar coisas novas como moringas com formato de frutas, azulejos com texturas. Foi ele quem criou o reconhecido boi-bilha, adaptando a tradicional bilha portuguesa à forma de boi.

Repetir fórmulas transmitidas é algo inerente e inexorável ao fazer artesanal e não deveria ser encarado de uma maneira depreciativa, afirma Coomaraswamy. O 
observador moderno pensa que essas artes, em que se expressam os mesmos motivos e se empregam os mesmos símbolos durante milênios, são monótonas, submissas, repetitivas, que pertencem a sociedades estáticas, de conhecimento inferior. No entanto, é por meio das artes tradicionais que nos damos conta do quanto a arte é uma imitação da natureza, em seu modo de operar:

Pois, assim como uma primavera sucede a outra primavera sem monotonia, assim também o povo, em quem desenhos 'idênticos' foram transmitidos de geração em geração, durante milênios, produz coisas do mesmo tipo que nunca são iguais (Coomaraswamy, 2001, p. 36).

Claudel afirmou: "A arte imita a natureza, não precisamente nos seus efeitos, mas nas suas causas, na sua 'maneira', nos seus procedimentos, que não são mais do que uma participação e uma derivação para as coisas da própria arte divina: ars imitatur naturam in sua operatione" (Claudel, 1968, p. 473).

\subsection{A gênese de um estilo}

Quando nos referimos ao estilo, não podemos restringi-lo apenas à maneira particular do artesão expressar-se, sem articulá-lo à cultura. Um estilo não se 
desenvolve como algo apartado da pessoa, corresponde ao seu modo de dar e de dar-se, é essência e integração, é doação e expressão.

Ao estilo, corresponde uma visão de mundo pessoal e coletiva, nela confluem a unicidade da experiência do autor e os valores de sua comunidade. O estilo é forma de cultura, afirma Ostrower (2004, p.102): "ainda que para o indivíduo o sentido íntimo de cada evento não precise derivar diretamente das valorações coletivas ou nelas se resumir, todavia nelas se elabora".

O aprendiz começa a aprender a técnica tentando imitar o estilo do mestre, ou seja, com uma ordem interna e uma expressividade que ainda não lhe pertencem, só mais tarde é que vai construir seu próprio estilo:

Como professor eu te passo um jeito, mas você pode descobrir o seu jeito de trabalhar, o seu jeito de confeccionar as peças. Eu te passo a minha técnica: como segurar, modelar o barro, o jeito que eu pego e tudo o mais, mas você pode descobrir que tem uma maneira melhor de fazer (Nelinho).

Dona Santa, 86 anos, pintora, começou a trabalhar aos 14 anos com a mãe. Ela construiu um estilo que Ihe permite hoje, ao pintar uma peça, acionar um gestual 
incorporado e um repertório próprio, gestados nos fazeres das mulheres pintoras de Maragogipinho, na urdidura do tecido social:

A gente não tem desenho para olhar, não, vem da cabeça. (...). A gente vai levando o pincel e o raciocínio vai chegando naquele momento, ali, quando puxa o ramo, assim, já surge outro, a gente vai criando, sempre vai surgindo alguma coisa. Cada uma faz a sua.

Arleide tem 21 anos e já é exímia pintora. Ela aprendeu com Zelita, sua sogra. Quando observei as pinturas das duas encontrei forte semelhança na pincelada, tive dificuldade em reconhecer diferenças entre a pintura de cada uma. Elas apreciam essa parecença. Como moram juntas, os próprios oleiros muitas vezes não sabem distinguir o traço de uma e da outra. Zelita, a mestra, revelou:

Eu conheço a minha pintura de longe. Quando vou a Salvador, que eu vejo a minha pintura: "olha a minha pintura ali, a minha e a de Arleide!". $A$ da gente é igual.

Arleide me fez ver duas peças pintadas por elas: 
Olhe, é igual! Repare! Se hoje eu e ela pintarmos e entregarmos pra Miro, por exemplo, pra quem ela pintava antigamente, ou para meu padrinho, Seu Zé, eles não sabem dizer se fui eu ou se foi ela.

O estilo, apesar de marcar o fazer singular do artesão, está embebido em seu legado gestual. O cultural e o biológico participam da constituição do processo criativo humano:

O meu pai de tanto me passar as técnicas dele e, também, por herdar geneticamente, eu trabalho igual a ele: o jeito, tudo. Eu só deixei de ser radical nas coisinhas muito certinhas como ele gostava. É porque essa coisa eu peguei dele, eu achava que tudo deveria ser assim, certinho, tudo muito bonitinho, mas depois a gente descobre que pode fazer outras formas, que a gente pode ter outro jeito de trabalhar, e que o pessoal também gosta. É, hoje tenho essa linha que eu criei aí. Não sei se eu criei ou se... Não sei, a gente tenta muito mudar uma coisa com outra, termina surgindo outra coisa. Essa linha eu criei, tem uns três anos que eu venho produzindo, o pessoal aceitou bem, todo mundo gosta (Nelinho).

O próprio artesão não sabe bem se foi ele quem inaugurou um estilo. Muito antes da concepção de uma peça, em profundas regiões onde os valores pessoais se 
entremeiam aos valores de seu grupo social e às decisões voluntárias, já se encontram os enfoques que irão determinar a conduta do artesão em todo o seu fazer.

\begin{abstract}
A imaginação de um tema, a escolha do formato apropriado ou de materiais e técnicas viáveis, até o próprio modo de trabalhar, as hesitações, as dúvidas e descobertas, as ordenações formais e as próprias referências ordenadoras, tudo está impregnado por considerações estilísticas. Intuitivas na maioria das vezes, sem precisarem alcançar o nível do consciente, tais considerações irão orientar integralmente o fazer artístico (Ostrower, 1983, p. 295).
\end{abstract}

A experiência criativa desenvolve no mestre artesão uma habilidade para escolha de combinações dentro de um repertório balizado por modelos culturais compartilhados e pelas próprias determinações e sujeições que a matéria inflige. A obediência às fontes e aos modos artesanais de fatura provém dos limites que 0 barro impõe. Em geral, o mestre artesão respeita profundamente a matéria. "A técnica é um fenômeno de relação entre o artista e a matéria que ele move. E se o espírito não tem limites na criação, a matéria o limita na criatura" (Andrade, 1975). 


\section{4. $O$ ensino e a aprendizagem da cerâmica}

Em Maragogipinho, as crianças aprendem olhando, fazendo e, sobretudo, desejando aprender. A estrutura desejante sustenta o processo de ensino e aprendizagem da cerâmica. De um lado encontra-se o mestre artesão que deseja partilhar seus conhecimentos, do outro está o aprendiz, que deseja saber. Alguns artesãos me relataram que quando pequenos, seus pais, mães, educadores, não os deixavam tocar nos materiais. Tinham que esperar o tempo certo para a iniciação. O mestre sabe alimentar, desde o princípio, a curiosidade e o desejo no aprendiz. Alguns dos meus entrevistados expressaram que sentiam tanta vontade de aprender que, frequentemente, praticavam escondido, quando o adulto se afastava.

É o caso de dona Rosalina Motta que hoje tem 85 anos e já não pinta mais porque quase não enxerga. A pincelada delicada e firme marcou sua maestria na pintura tradicional de Maragogipinho. Rosalina é referência entre as pintoras e os oleiros. Quando criança, era curiosa e enxerida. Ferreira Santos, em uma de suas aulas, revelou que o arquétipo do aprendiz vasculha onde menos se espera, até encontrar algo que possibilite a simbiose com o mestre para que o mestre, assim, 
se torne aprendiz do alto de sua maestria. Rosalina recorda da sua irreverência e do desejo que tinha de aprender a pintar na infância:

Eu pegava as peças quebradas, moringa, fogareiro e começava a treinar escondido de minha mãe, pois ela falava logo: "Olhe, não vá botar defeito em meu pincel". Mas eu era desobediente, toda vez que ela saía, eu pegava o pincel e mandava brasa! (Ferraz, 2011, p. 22).

Nelinho também se lembra de que, quando começou a tornear, aos dez anos, aproveitava os momentos em que o pai saía do torno. O pai, já falecido, era oleiro consagrado na comunidade. Ele mantinha o filho sob seus olhos, dentro da olaria. Quando o garoto manifestou o desejo de tornar-se aprendiz, o mestre mandou confeccionar-lhe um pequeno torno de madeira:

Sou filho de oleiro. Meu pai se chamava Nilson, ele é falecido. Minha mãe também sempre trabalhou com barro, no polimento, na pintura. No interior, a criação antes era assim: o pai tomava conta dos meninos e a mãe das meninas. Como na minha família, só tem eu de homem, o que acontecia: quando eu não estava no colégio, eu estava aqui na olaria com ele. Mas meu pai nunca me forçou a trabalhar. Ele só queria que eu estivesse ali, aos olhos dele. E eu sempre fui curioso, encostava aqui e aí 
começava a mexer, queria fazer e tal, e ele sempre observando. Quando ele saía do torno, eu então sentava no torno dele. Só que as minhas pernas eram curtas e não alcançavam o tripé, o apoio dos pés. Então, eu ficava pendurado. E às vezes eu caía em cima do tambor do torno e o torno me jogava e eu saía por baixo. E ele sempre observando, mas eu encarava. Ele então perguntou: “você quer aprender?" Eu disse: "eu quero", eu era curioso. Aí ele mandou confeccionar um torno menor, que dava pra mim. Eu era um garotinho ainda, não tinha nem noção do que eu queria da vida. Eu tinha nove pra dez anos. Aí ele começou a me ensinar. Eu aprendi a centralizar o barro, comecei então.

Esse pai foi um mestre severo, exigente, deixava uma peça sua de modelo para que o menino copiasse e, ao final do dia, retornava para verificar a produção. Com uma varinha na mão, ele ia batendo, desmanchando peça por peça, até restar somente uma: a do professor. Nelinho recorda que aquilo o entristecia, mas que no dia seguinte voltava ao torno animado para vencer o desafio. Até que um dia, o pai deixou uma peça do menino sem desmanchar, depois outra, outras, mais outras e, desse modo, Nelinho aprendeu a tornear:

Acho que não demorei a aprender porque o meu professor era muito radical. O meu professor era daquele tipo que só aprendia com ele 
quem queria aprender mesmo. Então, ele fazia uma pecinha, colocava em cima da bancada do torno, aquela bancada que a gente chama de 'Duquina', colocava ali e dizia: "faça igual a ela, a mostra está ali e você vai fazer igual". Aí eu levava a manhã toda naquilo. Às vezes era a tarde, porque dependia do turno em que eu estudava. Ficava ali. Quando eu já estava com uma quantidade já grande, assim, mais de dez ou quinze peças, chegava ao final daquele turno, ele aí pegava um pauzinho e vinha: pan, pan, pan, pan, pan, pan. Quebrava todas e só deixava a que ele fez. Dizia: "olhe, eu falei a você que eu quero que faça assim, como esta aqui!" Aquilo era uma dor, era uma dor! Eu chegava em casa e dizia: "eu não vou mais não, não vou mais". Mas no outro dia eu estava aqui... E aí ele batia, eu estava lá de novo. Até o dia em que ele começou a deixar algumas.

A marca do mestre manifesta-se na exigência incansável: "se o mestre pode exigir tudo dos discípulos, é porque nunca deixou de exigir tudo de si mesmo, sem alcançar a plena satisfação" (Gusdorf, 2003, p. 109).

Já Nené, aprendeu a tornear com avô, Cláudio Manuel Nazaré. O método do avô era semelhante ao do pai de Nelinho, só que um pouco mais brando. O mestre mandava que o próprio aprendiz desmanchasse as peças. 
Ele mandava a gente quebrar, dizia: “quebre que tá mal feito!” Ele não quebrava. Tinha uns que iam chegando e quebrando tudo. Mas ele não. Ele vinha com aquela calma dele: "quebre, que tá ruim, tá assim, assim...", mostrava o defeito (Nené).

E, apesar do desgosto, Nené quebrava as próprias peças, praticando o desapego, lição essencial para o aprendizado da cerâmica.

Dominar o barro no torno leva tempo. O corpo precisa repetir o gestual muitas vezes até aprender, até incorporar. Centralizar o barro é o primeiro movimento a se aprender e um dos mais difíceis, requer bastante prática.

É, porque o torno, ele depende de tempo e de paciência. Torno é incrível, torno é aquela história que eu te contei: se eu não tenho paciência, eu não aprendo. (...) O meu pai me ensinou todo o processo, como centralizar o barro (...). Mas ele perdia o tempo, às vezes ele deixava de fazer alguma coisa para me ensinar (Nelinho).

Assim como ocorria nas guildas medievais, os aprendizes da cerâmica aprendem imitando o mestre-artesão, que tem como foco o ensinar a fazer bem feito. Os mestres geralmente orgulham-se da qualidade que transparece em suas peças. 
Só que depois que eu centralizei e que ele viu que eu já tinha equilíbrio em centralizar o barro, foi que ele começou a ensinar a parte crítica mesmo, de querer que eu confeccionasse as peças com qualidade. Sempre o importante pra ele era qua-li-da-de. Qualidade para ele era que as peças estivessem perfeitas, com bom acabamento (Nelinho).

A simples imitação não gera satisfação duradoura no discípulo (Sennett, 2009, p. 328). O investimento no amadurecimento das habilidades é lento e esse vagar do tempo artesanal é fonte de satisfação porque abre largos espaços para a imaginação e a reflexão. "Maduro quer dizer longo; o sujeito se apropria de maneira duradoura da habilidade" (idem, ibidem). O aprendizado da cerâmica permite que o saber seja absorvido sem pressa pelo aprendiz, e passe a habitar os recônditos da sua memória.

O mestre não dá aulas, à maneira escolar, a não quando convocado por algum órgão público ou instituição para ministrar cursos. Só nesses casos, o ensino ocorre de modo mais formal. No dia a dia, porém, os mestres são observados e imitados pelos aprendizes em seus próprios locais de trabalho.

A maneira como o mestre ensina está estreitamente ligada à maneira como aprendeu. Nené relata que ensinou o filho a tornear com a mesma calma e com o 
mesmo método com que aprendeu com o avô, mandando-o quebrar as peças mal feitas. Já, Nelinho pôde atuar como professor em cursos formais. Desenvolveu uma metodologia própria para ensinar um grupo de crianças a tornear com apenas um torno. Fora de sua comunidade, fora dos espaços e tempos em que aprendeu a trabalhar o barro, ensinando um público de estrangeiros, teve de reinventar seu repertório de ensino:

Já dei aula lá em Salvador. Uma vez eu dei um curso de uma semana para uns garotos de 12, 13 anos. Só que foi meio complicado porque tinha menino japonês, tinha menino francês, tinha menino alemão, eu tinha só um intérprete. Era incrível, porque eles faziam perguntas todos de uma vez. Tinha só um torno e parece que eram 10 meninos. Mas o interessante era isso: enquanto um estava fazendo, os outros estavam observando, eu fazia isso com eles: faz a roda e vai observar. Eu fazia uma peça pra eles sentirem como era fazer, tudo direitinho. Mas eles ficaram tão empolgados, que eu acho que se o curso demorasse um ano, eles ficariam empolgados durante um ano. 


\subsection{A educação artesanal: do desígnio à liberdade de escolha}

Nascido em Maragogipinho, Nelinho tem quatro irmãs e é o único filho homem da família. Nelinho veio ao mundo com um desígnio: o de ser oleiro. Tornar-se um oleiro, em Maragogipinho, possui um significado amplo, não circunscrito apenas à atividade profissional. Mais do que dominar uma técnica e ter um meio de ganhar a vida, ser oleiro significa ocupar uma posição social de referência na comunidade, de protagonismo cultural.

Assim como a sociedade asiática, em geral, está firmemente baseada na vocação e só pode ser entendida sob o ponto de vista do desígnio, em Maragogipinho a prática e a tradição da cerâmica descendem de uma sucessão de mestre a discípulo, de uma geração a outra, em que o pai inicia o filho nos mistérios do ofício. No entanto, esse desígnio não pode ser entendido como um futuro preestabelecido. Nos depoimentos que colhi, depurei que esses mestres e mestras criam os filhos para o mundo, para as escolhas, para a autonomia. A educação nas comunidades tradicionais visa à formação, em seu sentido mais amplo, diferente de formatação. Nelinho aprendeu a arte do torno com o pai quando ainda era criança. Na juventude, fez uma tentativa para seguir carreira em outra profissão, 
foi para Salvador trabalhar em um escritório de contabilidade. O pai aceitou sua escolha:

Quando concluí meu segundo grau, eu disse: "vou embora". Falei para o meu pai: "vou morar em Salvador". E ele disse: "você vai fazer o quê lá?" Ele tinha um compadre que trabalhava lá, que disse: "manda Nelinho para cá que eu vou arrumar um emprego pra ele". Fui para lá, comecei a trabalhar num escritório de contabilidade. Estava até gostando, eu tinha uns dezoito para dezenove anos.

No entanto, seu desígnio possibilitou-lhe outra escolha:

Aí, meu pai teve um problema aqui, problema de saúde. Ele foi se tratar em Salvador. Foi uma dor de cabeça que apareceu nele do nada, fazia todos os exames e não dava nada. Nada, nada, nada. E ele estava cheio de encomendas aqui pra entregar. Meu patrão disse; "vá, resolva o problema da sua família que quando quiser você volta, a sua vaga vai estar aqui." Aí, eu vim para cá, eu já fazia quase tudo, comecei a fazer as encomendas, a entregar as mercadorias e tal. Meu pai chegou até a ser desenganado pelo médico, mas melhorou. Aí eu olhei assim e disse: "não, não vou deixar mais ele enfrentar isso tudo". Então fiquei, tomei a frente, produzia, entregava as encomendas dele (...). Depois de um bom 
tempo, meu pai adoeceu de novo e aí foi indo, foi indo, dessa vez ele... Bem, aí tive que arcar com tudo, porque só eu de homem na família, a sobrevivência da gente era isso aqui, toda sobrevivência nossa era isso aqui e aí eu produzia aqui.

Nelinho nasceu com o desígnio de ser oleiro, ele escolheu ser oleiro. Nesse sentido, desígnio assume o sentido de destino: de historicidade autêntica, segundo Heidegger. Para o filósofo, o destino é a decisão autêntica do homem de voltar a si mesmo, de transmitir-se a si mesmo e de assumir a herança das possibilidades passadas (Abbagnano, 2007, p. 286). O oleiro foi educado para ser livre para escolher ser ele mesmo.

Nelinho admite que cultivou o sonho de querer ser engenheiro, entretanto não teve chance. Hoje, com um filho ainda bebê, investe na formação do sobrinho, que acabou de terminar o Ensino Médio e vai prestar vestibular para engenharia em Salvador:

Sempre foi meu sonho fazer engenharia, mas eu nunca tive oportunidade na minha vida. (...). E tem ele [o sobrinho] que está querendo fazer, eu estou vendo se a gente consegue porque, quando nada, se eu não realizei o meu sonho, consigo ajudá-lo a realizar o dele. 
O artesão tradicional habita na contemporaneidade um território de ambiguidades. Tem consciência de seu desígnio, do valor histórico e social de seu ofício, mas por outro lado, não consegue garantir a partilha dos conhecimentos de que é portador. No Brasil, uma intrincada complexidade de fatores socioeconômicos contribui para minorar e degradar os saberes e a produção artística dos artesãos, impedindo que arte e trabalho permaneçam em planos equivalentes.

As novas gerações têm abandonado paulatinamente a cerâmica. Isso ocorre por diversos motivos, principalmente por causa do apelo econômico que os centros urbanos oferecem aos jovens. Com a crescente escolarização, muitos almejam fazer um curso superior e para isso necessitam abandonar o lugarejo.

Eu tenho dois sobrinhos, só que eles não querem ficar aqui. (...). Aqui ou vai ser servidor público, para ficar nessa luta, ou então vai trabalhar com o barro, que até pescaria aqui não é tão forte, agricultura também, nem se fala. O forte mesmo daqui é a cerâmica, (...). Eles gostam de trabalhar, mas querem coisa diferente... (Nelinho)

Dois netos adolescentes de Nené estavam na olaria em uma das ocasiões em que fui visitá-lo. O oleiro me explicou que estavam de férias e aproveitavam para 
aprender um pouco com o avô. Logo que começamos a conversar, os dois se aproximaram timidamente e perguntaram a Nené se já podiam ir embora. Ele ficou um pouco desconcertado porque a pergunta revelava nitidamente a falta de interesse dos jovens pela olaria. Dispensou os garotos.

Por sua vez, muitos dos rapazes e moças que permanecem em Maragogipinho fazendo cerâmica e, principalmente, os que vêm de fora em busca desse ofício, carecem de domínio técnico e de conhecimento sobre os modos de trabalhar com o barro. Um lamento geral que ouvi da voz dos mestres foi de que a qualidade da cerâmica vem decaindo.

Políticas públicas e ações educativas de ONGs são extremamente necessárias para salvaguardar esse patrimônio cultural, por meio do reconhecimento e da valorização de práticas, representações, técnicas, bem como dos próprios objetos artesanais, instrumentos e locais de trabalho. Nelinho e Nené tiveram uma oportunidade para ensinar o torno aos artesãos da comunidade, em um curso promovido pela PROMOART - Programa de Promoção do Artesanato de Tradição Cultural - com o intuito de resgatar e preservar os saberes da comunidade:

Eu fiz uma oficina para o pessoal daqui mesmo, para meninos que já trabalhavam no torno aprenderem técnicas diferentes. A gente montou 
os tornos lá na frente. Eles gostaram, eles aprenderam um bocado de coisas, justamente direcionadas a esse trabalho nosso, que é o tradicional, porque ele está morrendo! Nem todo mundo sabe trabalhar com ele. E eles não sabiam como é que fazia uma baiana, como é que fazia um boi, a gente foi passar as técnicas para eles. Aí fui, precisava de dois instrutores, eu chamei o meu vizinho, o Nené, um senhor bem mais velho. Ele tinha até mais experiência do que eu. Aí foi legal, a gente fez, eles gostaram e produziram muitas peças, produziram bem, foi bom.

Cursos de pintura para as mulheres também foram oferecidos na AAMOM para preservar a memória e a continuidade dos ofícios. Os mestres e mestras que ensinaram os jovens da comunidade descobriram que há uma demanda real para esses ensinamentos. As ações educativas, portanto, constituem um modo de alimentar o sentido social desse tesouro, são de valor inestimável:

Tem um [dos rapazes que fez o curso] que me disse: "Pô Nelinho, eu gostei muito do curso!" Ele trabalha assim: vai às olarias e faz as peças para outras pessoas. Só que ele não tinha bem um conhecimento de como fazer, vamos dizer, de como fazer uma bacia menor, ele fazia da maneira que achava que deveria ser. $E$ olhe que o pai era um profissional excelente, morreu, mas não passou para ele. Eu achei até que o curso não ia dar muita repercussão, porque era para meninos 
daqui, eu pensei: "eles já sabem tudo, trabalham direto". Mas não, funcionou legal e eu vi que eles estavam precisando e precisam demais. Precisam ainda muito mais porque foram poucas aulas, não dá para se passar muita coisa. Você trabalha com torno, sabe que é uma coisa que depende de tempo.

Em Maragogipinho, assim como em várias comunidades rurais, enquanto muitos jovens partem, os mais velhos se mantêm enraizados. Aceitam a inexorabilidade da dispersão do seu grupo original, porém fixam-se na terra materna protagonizando a resistência de sua cultura. O enraizamento é uma das necessidades humanas mais vitais, conforme Simone Weil:

O enraizamento é talvez a necessidade mais importante e mais desconhecida da alma humana. É uma das mais difíceis de definir. O ser humano tem uma raiz por sua participação real, ativa e natural na existência de uma coletividade que conserva vivos certos tesouros do passado e certos pressentimentos do futuro (Weil, apud Frochtengarten, 2009, p. 96).

Nessa perspectiva, a educação artesanal assume mais um sentido que transcende a instrumentalização para o ofício. Frente à dispersão do grupo original, para além 
da transmissão de conhecimentos, a educação artesanal vai ao encontro de uma educação que tem um fim em si mesma, que faz brotar e desabrochar o singular na pessoa. É o "torna-te o que tu és" nietzscheano, que se expressa como amor fati (Ferreira-Santos, 2012, p. 70). Nietzsche vê a grandeza do homem na necessidade do devir cósmico como vontade de reafirmação: "é preciso fazer o voto de retorno de si mesmo com o anel da eterna benção de si e da eterna afirmação de si; é preciso atingir a vontade de querer retrospectivamente tudo o que aconteceu, de querer para frente tudo o que acontecerá" (Nietzsche apud Abbagnano, 2007, p. 286).

A educação artesanal não mira somente para o passado e para a sua preservação, dentro de uma noção linear e unívoca de tempo. Assim como na tradição quéchua, em que o passado está à frente da pessoa porque lhe conforma o olhar e o futuro está às suas costas porque é desconhecido, a educação artesanal se funda na ancestralidade e na criação, no constante diálogo entre a tradição e a emergência do novo.

Paul Ricoeur afirma que a nossa dívida com a ancestralidade é que temos que ser nós mesmos, "na medida em que somos o futuro que este passado tinha e nos cumpre atualizar suas energias mobilizadoras e fundadoras" (Ricoeur apud 
Ferreira-Santos, 2012, p. 61). A educação artesanal, portanto, se consagra na liberdade de escolha da pessoa por ser ela mesma, por protagonizar a sua história e a de seu grupo cultural.

\subsection{Mestres e mestras}

Uma pesquisa acadêmica obedece a um tempo delimitado, muitas vezes exíguo para o pesquisador das ciências humanas transpor camadas mais profundas do tecido social e dos aspectos identitários da comunidade que investiga. Os ritmos de uma sociedade tradicional rural, como Maragogipinho, são vagarosos, o trabalho com o barro imprime um tempo desacelerado, que alonga a percepção da subjetividade dos fenômenos. A fenomenologia nos dá a dimensão do valor de cada pessoa na afirmação da identidade da comunidade, o que justifica meu interesse na continuidade deste estudo em um futuro próximo. Portanto, as vozes dos mestres e mestras, abaixo, soam ainda módicas para a potência sonora que podem alcançar. 


\subsubsection{Vitorino}

Vitorino é o mestre dos mestres. Foi citado por quase todos os oleiros e pintoras. Conversei com ele duas vezes. Na primeira vez, passei em sua casa pela manhã e a filha Nádia me orientou a voltar na parte da tarde. Ele havia saído. Um pouco mais adiante, no caminho, cruzei com um senhor de cabelos brancos e olhos claros, altivo e simpático. Sorriu para mim sem saber quem eu era.

Quando retornei, percebi as singularidades da casa do mestre: fica numa esquina e se destaca pelas belas paredes de cerâmica. Por fora, é toda revestida de azulejos cerâmicos texturados, sem colorido, da cor do barro cozido. Uma trepadeira de rosas cresce entre as janelas da frente.

Mestre Vitorino me esperava com ansiedade. Nádia havia me dito que ele adorava dar entrevistas. Notei duas cadeiras na varanda para que conversássemos. Quando Vitorino apareceu, reconheci o homem que havia encontrado pela manhã. Estava lindo: vestia camiseta e bermuda, com o cabelo e a barba cuidadosamente aparados, cheirando a banho recém-tomado. É um senhor de porte pequeno, e olhos fulgentes. Aos 94 anos, move-se com destreza e esbanja simpatia. 


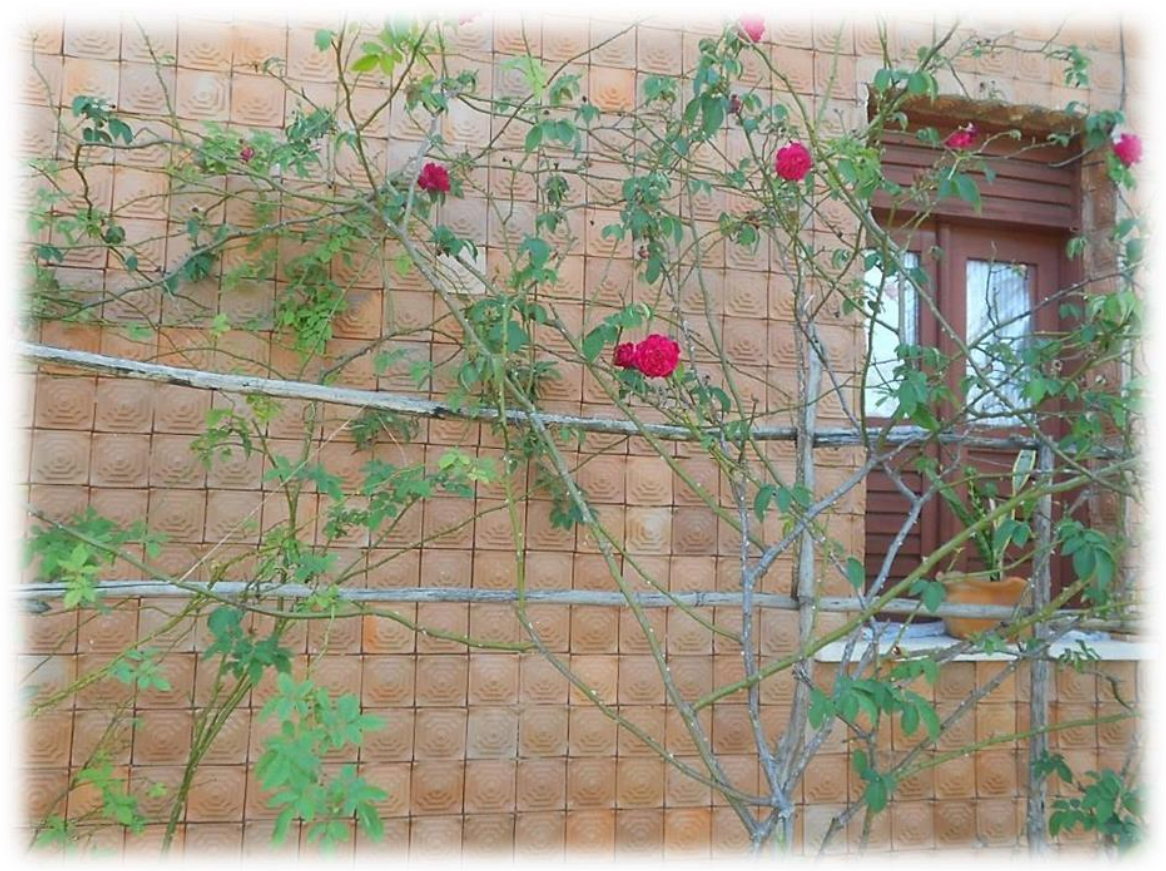

Parede externa da casa de Mestre Vitorino

Vitorino está surdo e quase cego. Fui orientada a escrever as perguntas numa prancheta que, prontamente, me foi oferecida por Nádia. Por escrito, me apresentei e pedi a Mestre Vitorino que me contasse a sua história. Ele demonstrou ter gostado da pergunta - tão genérica - e logo começou a falar. Dava tom calmo à narrativa, articulava bem os fatos, como se já tivesse contado a sua vida mais vezes. Demonstrou vivacidade e bom humor, riu solto por várias vezes. 
Apesar da idade avançada, é um homem totalmente lúcido, se expressa bem oralmente, encadeando os episódios em sequência e, nas vezes em que foi interrompido, retomou a narrativa exatamente do ponto em que havia parado.

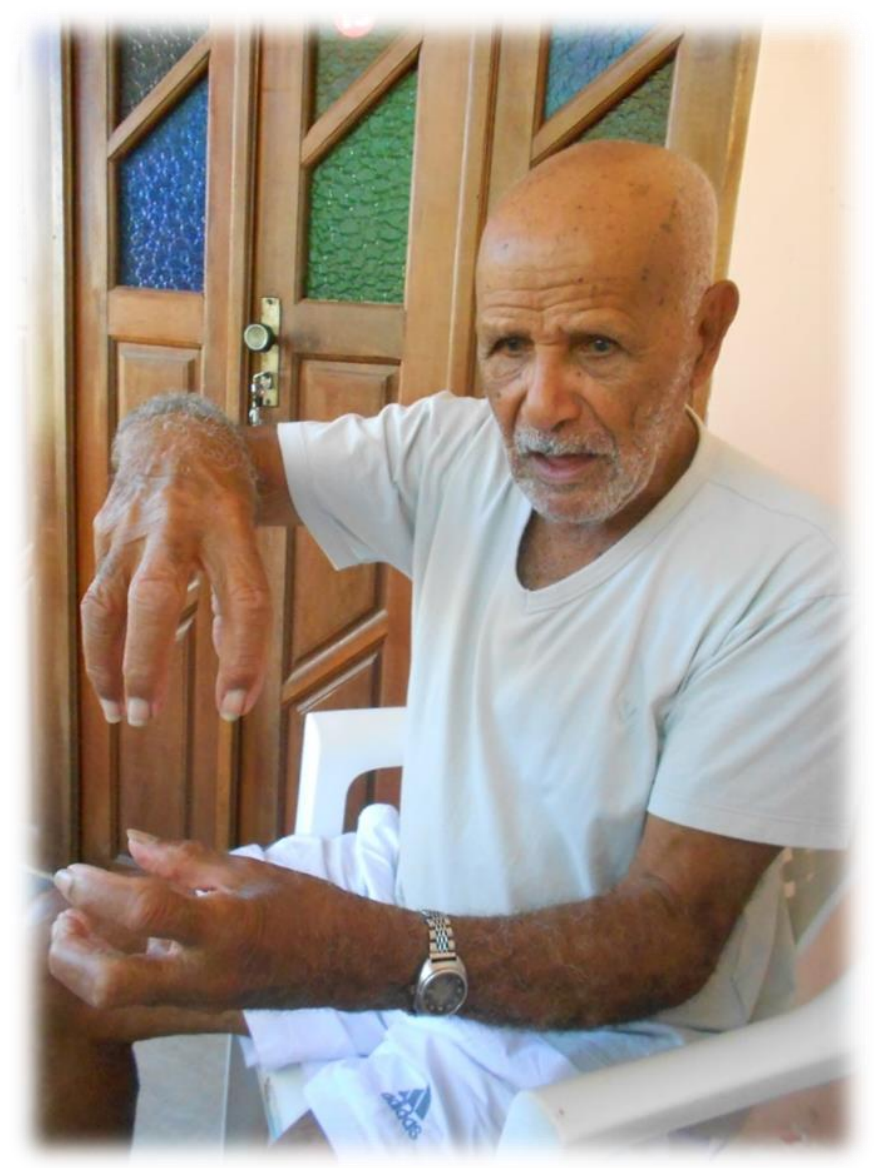

Mestre Vitorino 
Vitorino Bertoldo Moreira nasceu em Maragogipinho em 29 de março de 1920. Aos dez anos de idade começou a trabalhar no barro, como quase todas as crianças da comunidade. Aprendeu o ofício com Silvestre Costa, um reconhecido mestre do lugar. Foi com ele que adquiriu amor pela cerâmica. A distância da escola e as condições econômicas de seus pais não permitiram que continuasse os estudos além do quinto ano primário. Ele fez questão de justificar porque não completara a escolarização: a escola ficava em Nazaré das Farinhas e, naquela época, o caminho de terra até lá era difícil, precisavam ir de canoa, o que demorava demasiado.

Vitorino é reconhecido nacionalmente e internacionalmente. Disse-me que nunca plagiou nada, sempre gostou de inventar coisas novas. Foi ele quem criou o boibilha, símbolo de Maragogipinho. Queria conceber uma coisa diferente, então viu o boi de Mestre Vitalino, ceramista pernambucano, já falecido. Adaptou a bilha, artefato tradicional de origem portuguesa, puxando um dos lados para compor a cabeça do boi e o outro para formar o rabo.

Eu estava na Feira de Água de Meninos e o povo procurando pelo boi de Vitalino. Eu vi o boi de Vitalino. Aí eu disse: 'Não quero o boi de Vitalino, não quero a bilha de origem portuguesa, vou criar o meu'. Pronto. Aí 
criei o meu boi-bilha. (...) Eu levei uma média de seis meses para fazer a forma oval, porque toda a peça no torno, só faz redonda.

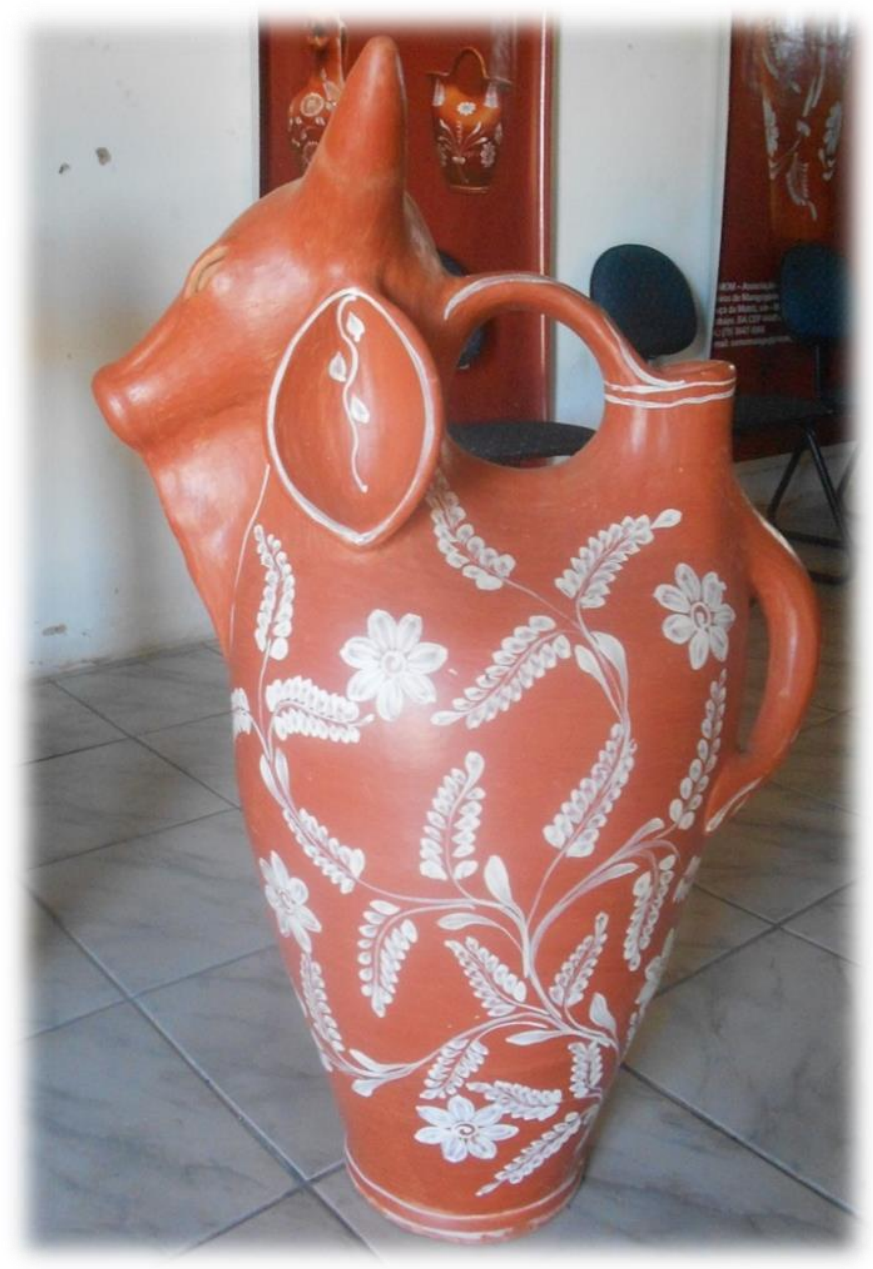

Boi-bilha de Mestre Vitorino

(Acervo AAMON) 
Resultado de pesquisas e de amadurecimento técnico, o boi de Vitorino, pintado no tauá e na tabatinga, recebeu menção honrosa da ONU em 2004, no Festival de Artesanato dos Países da América Latina e Caribe. Vitorino foi à Nova lorque receber o prêmio. Ele já levou suas peças para vários lugares, participou de feiras e exposições. Entretanto, considera que não teve uma justa recompensa pelos mais de 80 anos de trabalho na cerâmica:

Eu não tive recompensa, de nada. Trabalhei a vida toda. Em todos os eventos eu participava. Se a Bahiatursa me chamava: 'vamos fazer um evento no Rio', eu estava lá. Se dissesse: 'vamos pra Rio Grande do Sul', eu estava lá. Vamos para... Para onde fosse... Nunca me chamaram foi pro inferno, mas pra todo canto me chamaram (risadas) $!^{10}$

Enquanto falava, fazia caretas e gesticulava muito, de modo bastante expressivo. Demonstrava orgulho de sua trajetória. Revelou que a minha era a 51 ำ entrevista que concedia.

Inventou moringas com forma de frutas: pitanga, cacau, mamão. Outra criação sua são os azulejos texturados, que revestem as paredes da sua casa. Também

${ }^{10}$ Depoimento dado no documentário: “Mestre Vitorino: histórias do barro", 2008. 
criou azulejos de barro pintados com tauá e tabatinga., No Hotel Catharina Paraguaçu, em Salvador, há uma sala de comer toda decorada com azulejos e peças de Vitorino, pintadas por Rosalina.

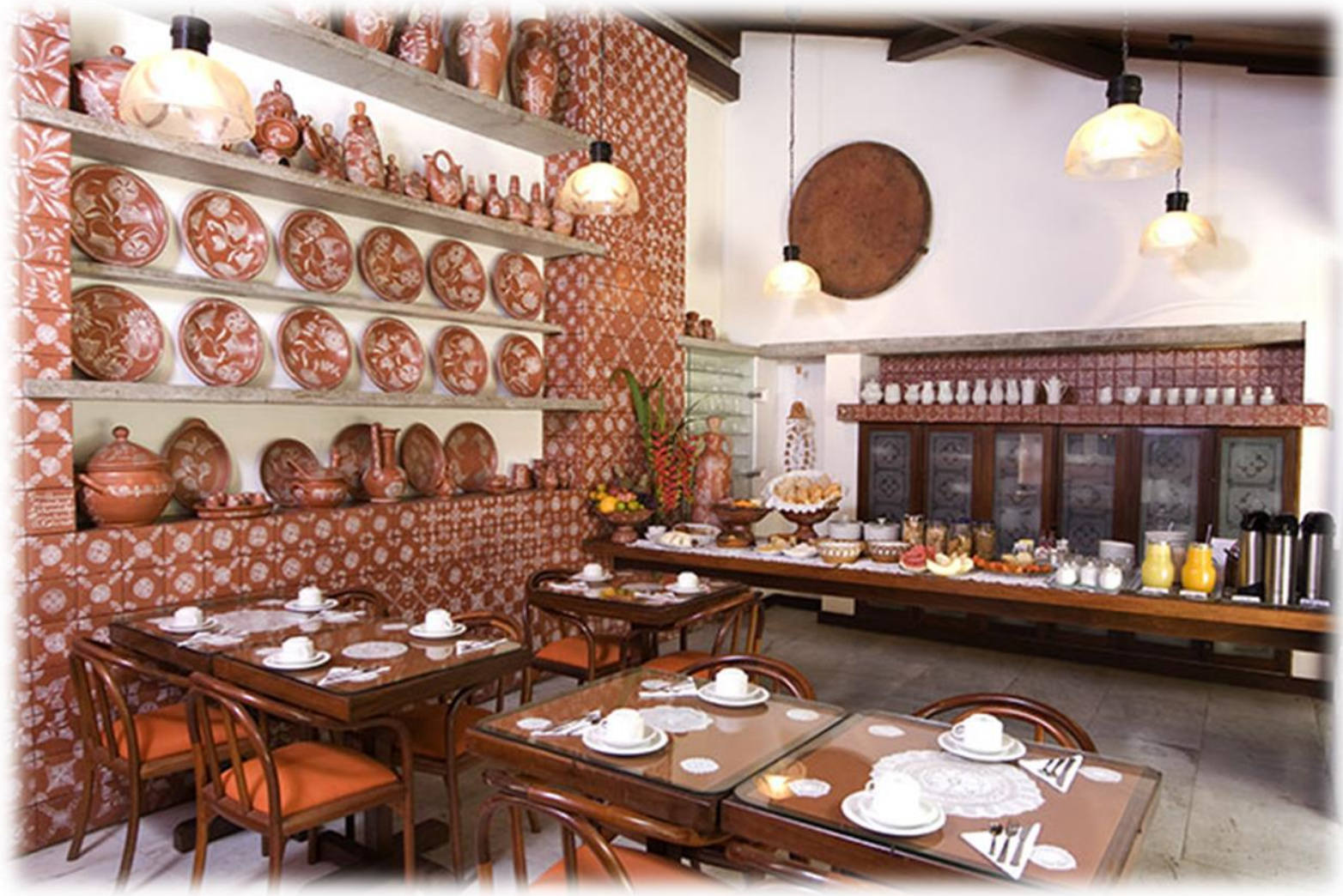

Comedor do hotel Catharina Paraguaçu 
Durante muito tempo, Vitorino teve uma barraca na Feira de São Joaquim, em Salvador, onde vendia as suas peças e as de artesãos de Maragogipinho. Além de produzir, também comercializava a sua cerâmica e, pelo seu jeito comunicativo, devia vender bem. O mestre também foi presidente da AAMOM, vereador e presidente da Câmara dos Vereadores de Maragogipinho. Diz ter abandonado os cargos por não possuir vocação política. Pensei comigo que, pelo contrário, com aquela simpatia e facilidade de comunicação, ele deve ter sido um bom político.

Vitorino teve quatro filhos biológicos e alguns adotivos. Seu único filho homem não quis ser oleiro. Quando chegou neste tema, logo desviou o assunto e revelou, com orgulho, que tem um filho adotivo que seguiu na profissão, mas que não se tornou um oficial. Guilherme herdou a olaria do pai, modela e emenda as peças, porém não vai ao torno.

Ele não me falou nada sobre a sua saúde, mas pude perceber que não está mais trabalhando e que tem muita energia represada. Contou-me lamentoso que recentemente mandara um trabalho de barro para o Projeto Talentos da Maturidade, em São Paulo, porém não fora premiado. 
Encontrei em Vitorino vitalidade e alegria, uma força de mestre, de quem olha pra trás e constata que a vida valeu a pena. Por meio do barro, ele construiu toda uma existência de dignidade, de protagonismo e de reconhecimento social.

\subsubsection{Nelinho}

Conheci Nerivaldo Moreira Mota, o Nelinho, no primeiro dia em que visitei Maragogipinho. Já havia assistido a um vídeo na internet em que ele aparecia ao torno, dando um depoimento. Mas somente ali, no momento em que o vi na olaria, é que percebi que contribuiria muito com a minha pesquisa. Receptivo e atencioso, sem saber nada de mim, imediatamente me fez sentar e principiou a falar de seu ofício, sua origem, sua família, seu lugar.

Com 47 anos, porte pequeno, corpo forte, Nelinho vestia bermudas e camiseta. Notei-Ihe o tônus vigoroso dos músculos dos braços, bem proeminentes, assim como os das pernas. A pele grossa e a aspereza das mãos me revelaram o grau de intimidade que mantém com o barro. 


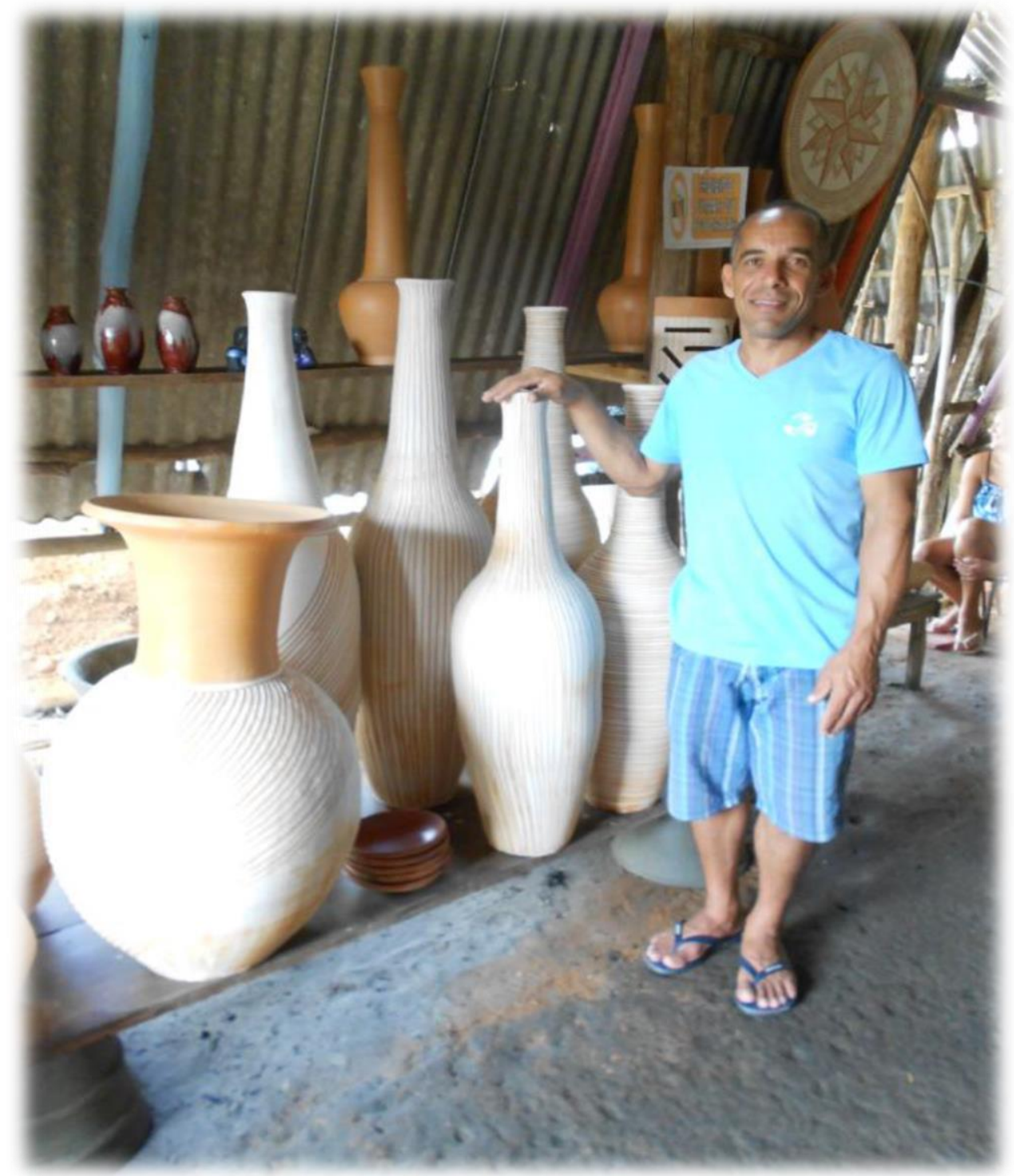

Mestre Nelinho em sua olaria 
Se a aparência, por um breve momento, transpareceu rudeza, isso logo se desfez quando começou a expressar-se. De fala mansa, doce, Nelinho articulava as palavras com clareza. É um homem suave, demonstra uma sensibilidade aguçada. A delicadeza que vi em Nelinho e que, posteriormente, reconheci em outros oleiros me remeteu a uma afirmação de Bachelard (2001, p. 67):

A matéria suave suaviza as nossas cóleras. Como a fúria não tem nenhum objeto no trabalho dessa esplêndida moleza, o sujeito torna-se um sujeito de suavidade.

Trabalhador, Nelinho fica na olaria de sol a sol. Contou-me que é muito curioso e que gosta de experimentar novas possibilidades com o barro:

Tudo eu quero testar, tudo eu quero ver se consigo fazer, nessa brincadeira vou fazendo um pouquinho de tudo. (...) Eu tenho mil e uma profissões. (...) A gente trabalha aqui e termina sendo um pouquinho arquiteto, um pouquinho engenheiro, um pouquinho decorador.

As obras desse artesão são de uma beleza singular. Além de desenvolver a técnica tradicional de Maragogipinho, também produz uma cerâmica de estilo próprio: 
grandes vasos, fruteiras e talhas com um riscado de linhas brancas, contínuas e paralelas, sobre o fundo âmbar. Pratos coloridos enfeitavam as paredes da olaria:

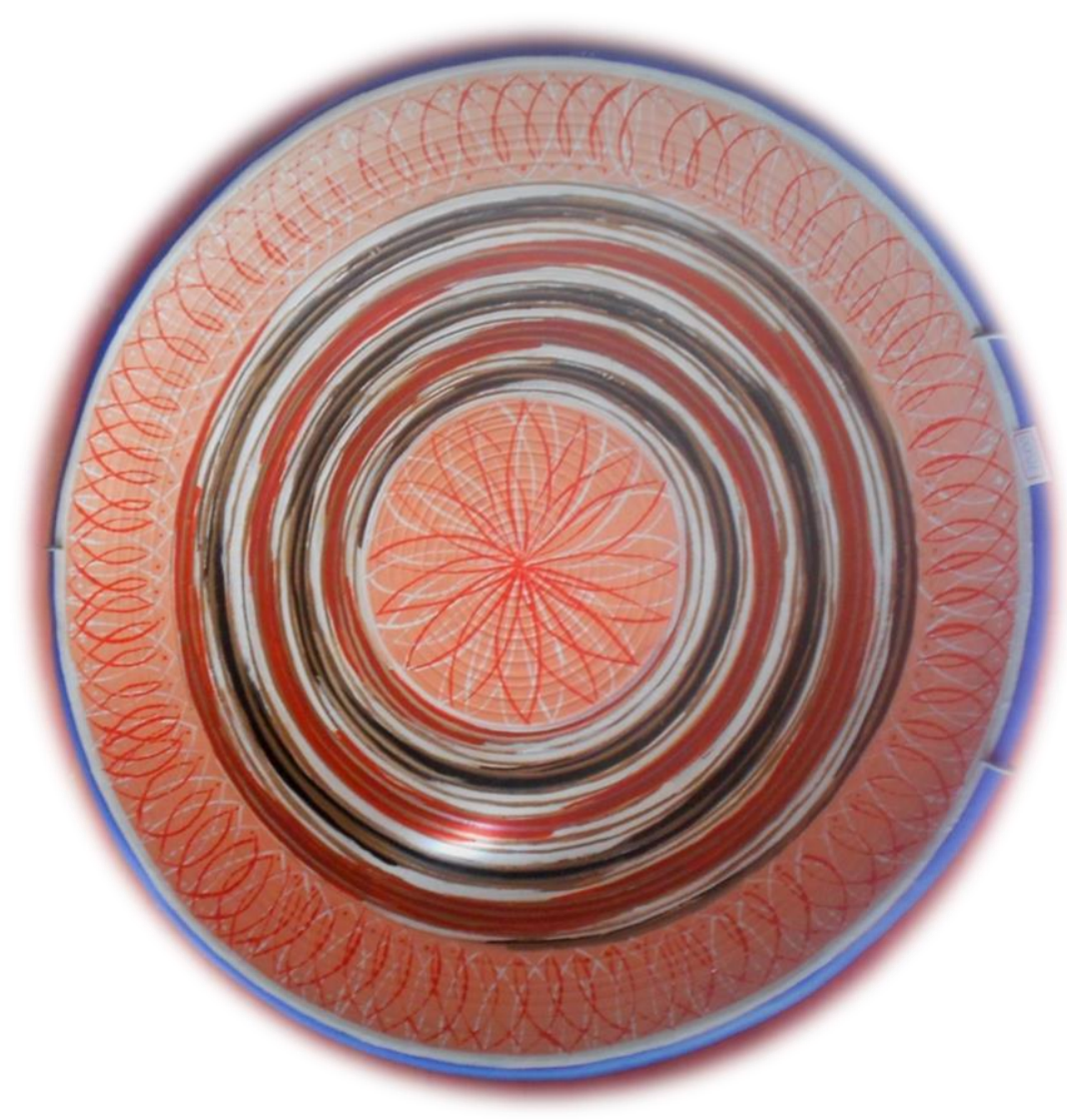

Prato confeccionado por Mestre Nelinho 
Durante o primeiro bate-papo com Nelinho, quase não falei palavra. Também não quis gravar seu depoimento para não formalizar a conversa. Deixei que a prosa fluísse. Em vários momentos, me comovi, ele disse coisas sobre seu caráter, seus valores, seu trabalho, que me tocaram profundamente. Ao seu lado, experimentei novamente aquele sentimento que nutria por meus alunos da EJA, de amor pelo humano, de admiração pelo modo como as pessoas desfavorecidas mantêm sua dignidade. Tive a certeza de que retornaria para conhecê-lo melhor, e à sua família também.

Nos dias que se seguiram, voltei a dialogar com Nelinho. No total, foram três longas conversas com ele. Conheci sua esposa, Rosângela, que é enfermeira em Salvador, duas de suas irmãs: Nailse e Neusa, ambas exímias pintoras; um sobrinho adolescente, Isaac, e a mãe, Dona Santa, a quem entrevistei também. A marca da família é a delicadeza, todos falam com polidez e tratam-se entre si com amabilidade e respeito.

- Nelinho, como é viver do barro?

É um trabalho infinito, a palavra é esta, porque a cada dia a gente aprende uma coisa nova, a gente descobre algo diferente. A gente pode saber de muitas coisas, mas a gente nunca sabe tudo. (...) Este trabalho 
daqui é bom, mas tem horas que a gente cansa, aí dá a louca e a gente diz: 'Eu vou parar, eu vou embora, eu não vou mais fazer isto não, eu tô cansado, eu trabalho aqui desde criança, tem que ter outro pra ocupar o meu lugar!' Mas depois a gente acalma e volta de novo.

A tensão vivida pelos artesãos tradicionais é constante, principalmente por aqueles que não asseguram herdeiros para ocupar o seu lugar. Na última vez em que nos vimos, recebi de Nelinho uma linda moringa torneada por ele e pintada com tabatinga por sua irmã. Fiquei extremamente grata por haver-lhe conhecido e com forte desejo de voltar a reencontrá-lo.

\subsubsection{Seu Zé}

Seu Zé foi o segundo artesão que conheci em Maragogipinho. Recebeu-me com simpatia e cordialidade. Seu nome é Taurino Silva, mas só atende por "Seu Zé", que é também como assina as peças de cerâmica.

Cinquenta e seis anos, de porte médio e pele morena, Seu Zé é forte e musculoso. Muito educado, me atendeu descalço e sem camisa nas três vezes em que conversamos. A simplicidade e o calor me sugeriram que esse é o modo apropriado dos oleiros apresentarem-se aos fregueses, a caráter. 


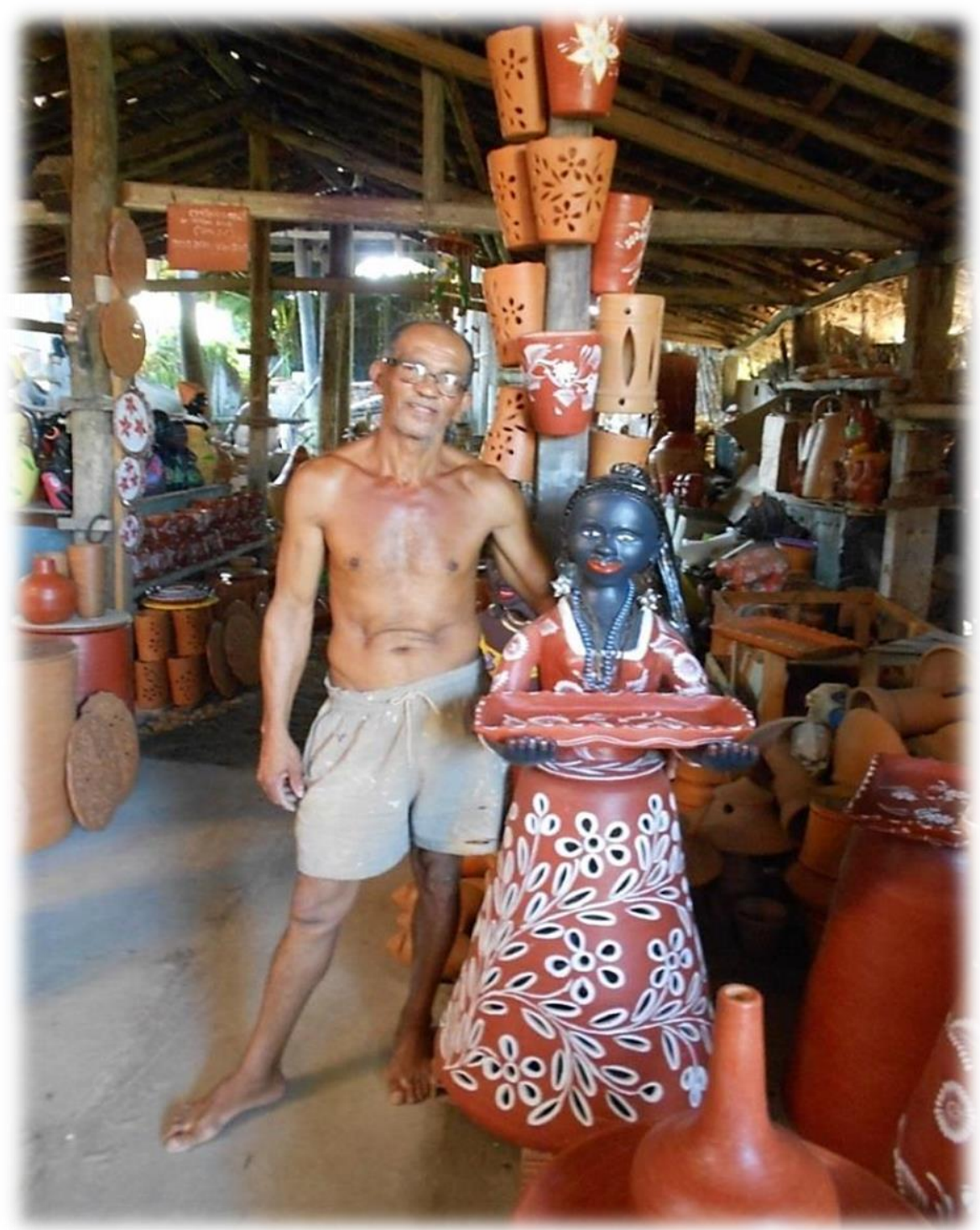

Mestre Seu Zé em sua olaria 
A grossura das mãos e o calejado dos pés contrastam com a sensibilidade e delicadeza desse homem. Mais de uma vez, atestei nele a suavidade de quem trabalha com o barro. Vi requinte e esmero nas grandes peças em estilo vazado que produz - baianas, bois-bilha, xícaras gigantes - pintadas pela esposa ao modo tradicional, com tauá e tabatinga.

Bem humorado e risonho, Seu Zé prontamente começou a desfiar a sua vida em nosso primeiro contato, antes mesmo de eu gravar qualquer palavra. Disse-me que, quando criança, carregava as peças para as mulheres brunirem. Mais tarde, na ordem dos aprendizados, amassava o barro com os pés e com as mãos. Seu Zé iniciou-se cedo no torno, aprendeu com seu pai de criação:

Eu comecei mesmo a trabalhar no torno com a idade de treze anos. Eu aprendi com o meu pai de criação, um artesão tradicional, o nome dele era José da Silva. O traçado veio mesmo de família. Aqui qualquer criança de dois, três anos, ele começou a andar, já começa a mexer com o barro. Começou a andar, chegou aqui na olaria e já não tem o que escolher, ele vai pegar no barro. Não vai pegar noutra coisa a não ser no barro. Qualquer criança já pequena vai se melar toda, é só ele vir na olaria, ele tem aqui na olaria coisa pra fazer com barro. 


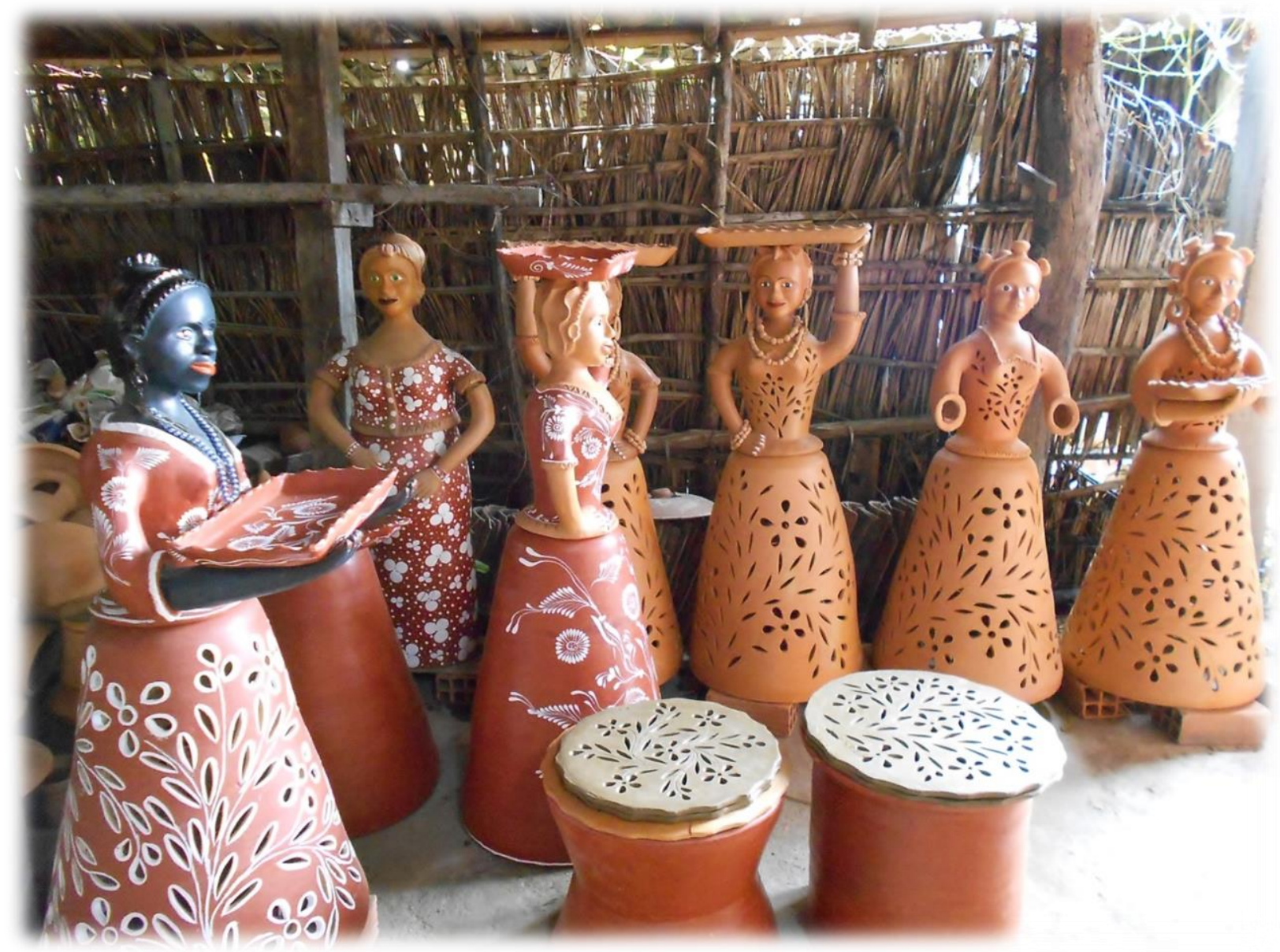

Baianas na olaria de Mestre Seu Zé 
Seu Zé me ensinou que o aprendizado da cerâmica se inicia pelo acabamento. 0 aprendiz não deve começar erguendo as peças. A iniciação no torno ocorre pelo acabamento em objetos semi-prontos, quando esses se encontram em "ponto de couro", um estado do barro entre o seco e o úmido.

Começa pelo acabamento antes do torno. O importante é começar pela parte mais difícil, a parte do torno é fácil e acabamento é a parte mais difícil.

Realmente, o acabamento é o que requer mais perícia e destreza do artesão. No acabamento aprende-se a enxergar o perfil da peça, se ela tem sobras, se as paredes estão muito grossas. O acabamento também inclui os detalhes, as minúcias, os ornamentos.

Em seu Zé, novamente pude atestar refinamento e densidade de caráter. Quando falamos sobre sua vida, me contou que tem um único filho, de vinte e poucos anos, que não seguiu a carreira de oleiro porque sofre de uma doença psíquica. Deduzi o quanto esse homem deve ter desejado que o filho aprendesse a trabalhar com o barro. Contudo, com resignação e amor incondicional pelo filho, contou-me que nunca forçou para que trabalhasse na olaria e que lhe dedica 
muitos cuidados, levando-o ao médico regularmente e deixando de dormir à noite quando ele não passa bem.

No final de nossos encontros, comprei dele umas peças. Quase levo "gato por lebre": um boi-bilha que não havia sido pintado com tabatinga e sim com tinta acrílica branca. Contudo, foi o próprio seu Zé quem me alertou, meio embaraçado, que eu não iria dar tanto valor àquele boi selecionado, já que a minha atração era pela pintura tradicional.

Escolhi, então, um grande boi-bilha pintado no tauá e na tabatinga. Esse boi viajou em caminhão quase dois mil quilômetros até chegar à minha casa. $O$ preço do transporte foi maior do que o preço da peça, o que é inadmissível: o ganho do artesão acaba sendo extremamente baixo para desonerar o consumidor, enquanto quem lucra é o transportador. Seu Zé me havia dito que um boi grande demora, em média, vinte dias para ser confeccionado.

Uns dias após deixar Maragogipinho, atendo o telefone e escuto uma voz bem disposta, com forte sotaque baiano... Era seu Zé informando que meu boi estava a caminho. 


\subsubsection{Dona Santa}

Dona Santa... é assim que a artesã Nair Moreira Mota é chamada por todos em Maragogipinho. Dona Santa tem 88 anos, é mãe do Mestre Nelinho, vive com duas filhas adultas e dois netos adolescentes. Conversamos dentro de sua casa e, assim que entrei, pude compreender melhor porque a delicadeza é a marca daquela família. Quando me aproximei da porta de entrada, ouvi um som suave de trompete que vinha lá de dentro. Achei que era procedente de um aparelho de som, no entanto a música parou e logo fui apresentada ao intérprete (que tocava muito bem por sinal): Isaac, um jovem neto de Dona Santa.

Extremamente amável, Dona Santa é uma mulher idosa, de corpo e mãos pequenos, porém ágil, graciosa. Desloca-se com leveza pelo espaço, fala calmamente, em tom baixo; é católica devota e manifesta o tempo todo a sua religiosidade. 


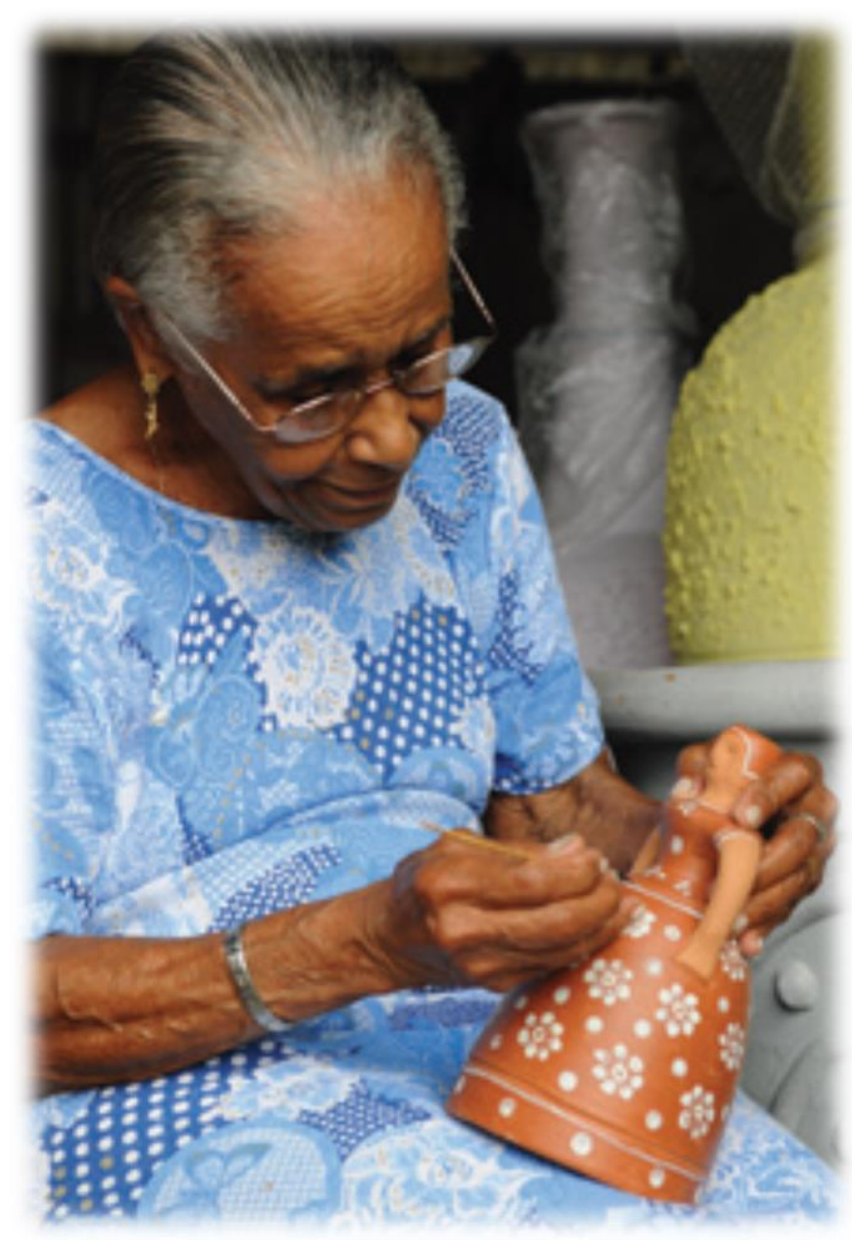

Mestra Dona Santa

(Ferraz, 2011, p.74)

A casa é ampla, se sobressai entre as outras casas da rua. Na parte da frente, há uma varanda adornada com duas grandes talhas, uma de cada lado. Essas peças 
foram confeccionadas por Nelinho para imitar o estilo do pai: um riscado de retângulos, como se fossem tijolos emparedados. Uma limpeza impecável transparecia no ambiente arejado e cuidadosamente decorado com flores artificiais. Não avistei objetos de barro, mas o piso da sala de azulejos cerâmicos antigos encheu meus olhos.

Sentamos as duas à mesa da sala. Neusa, a filha, também exímia pintora e mestra, juntou-se a nós e tomou parte na prosa, principalmente quando a mãe the demandava auxílio. O curioso é que passamos longo tempo falando sobre o trabalho de pintura das duas e não havia nenhuma peça delas na casa, somente um pequeno pato foi encontrado em um canto da sala para que Dona Santa me revelasse em uma peça como são os movimentos da pintura.

Nesse ponto da conversa, quis mostrar seu pincel que estava guardado a sete chaves, envolvido cuidadosamente em um pano. Foi como desembrulhar um tesouro: o pincel fora feito por ela mesma com pelos de gato retirados do lombo do animal e amarrados a um talo de palmeira. Uma preciosidade. Aquele simples instrumento transpirava sapiência, era parecido a um pincel chinês em que o caimento do pelo se atenua, gradativamente, até a ponta, e permite uma pincelada fina e precisa. 


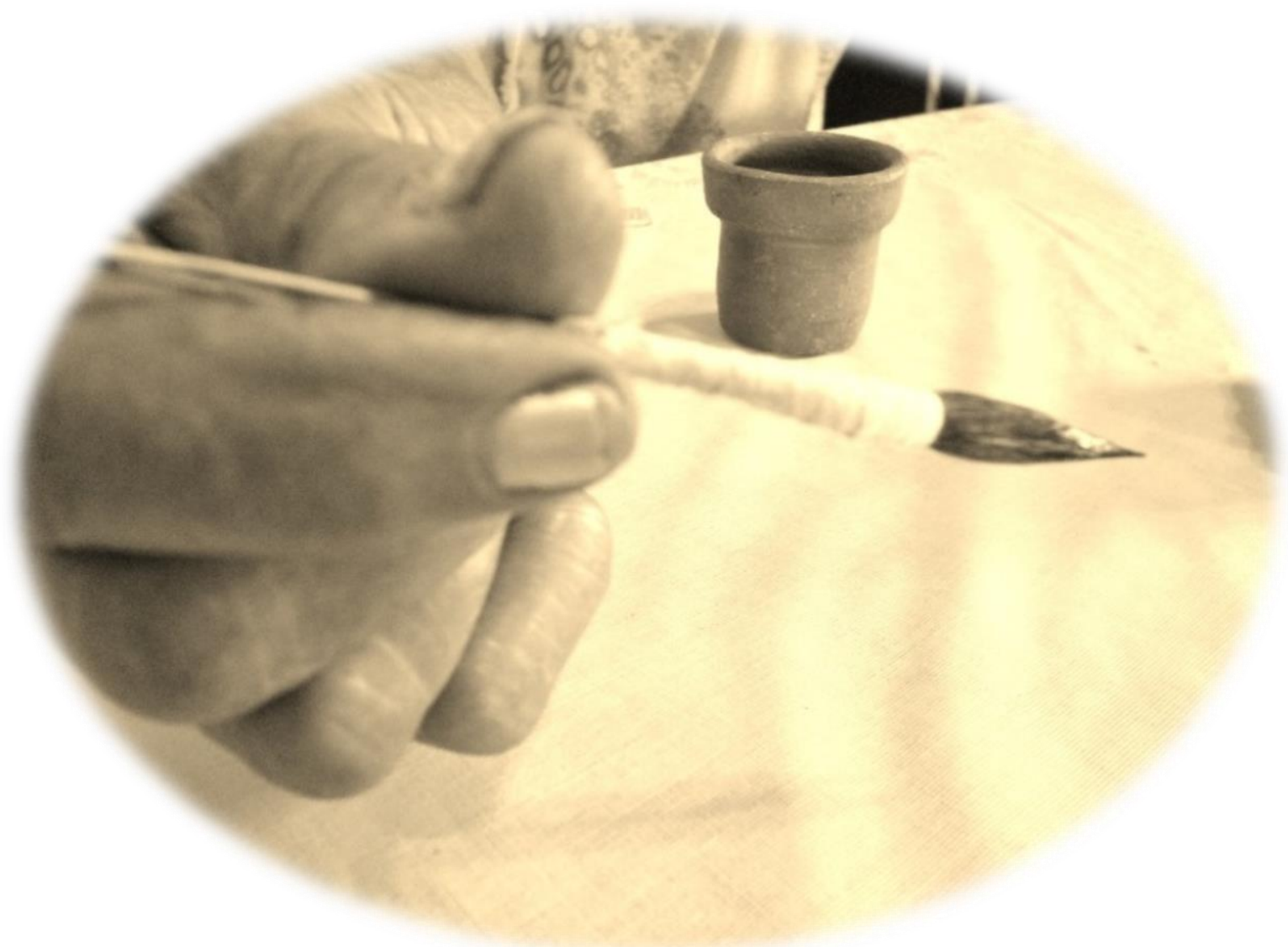

Pincel de pelo de gato, confeccionado por Dona Santa 
Dona Santa fingiu pintar, demonstrando como executa a pintura com tabatinga:

Tem que ter a mão leve. É este dedo aqui [o mínimo] que apoia e acompanha a pintura. (...) Quanto mais aliviar a mão, mais sai a pintura fina.

Os movimentos que a sua mão pequena e enrugada descreveram foram graciosos e ágeis, de quem possui amplo domínio da técnica de pintura. Ela contou-me que aprendeu com a mãe aos 14 anos e, mais tarde, ensinou as quatro filhas a pintar. 


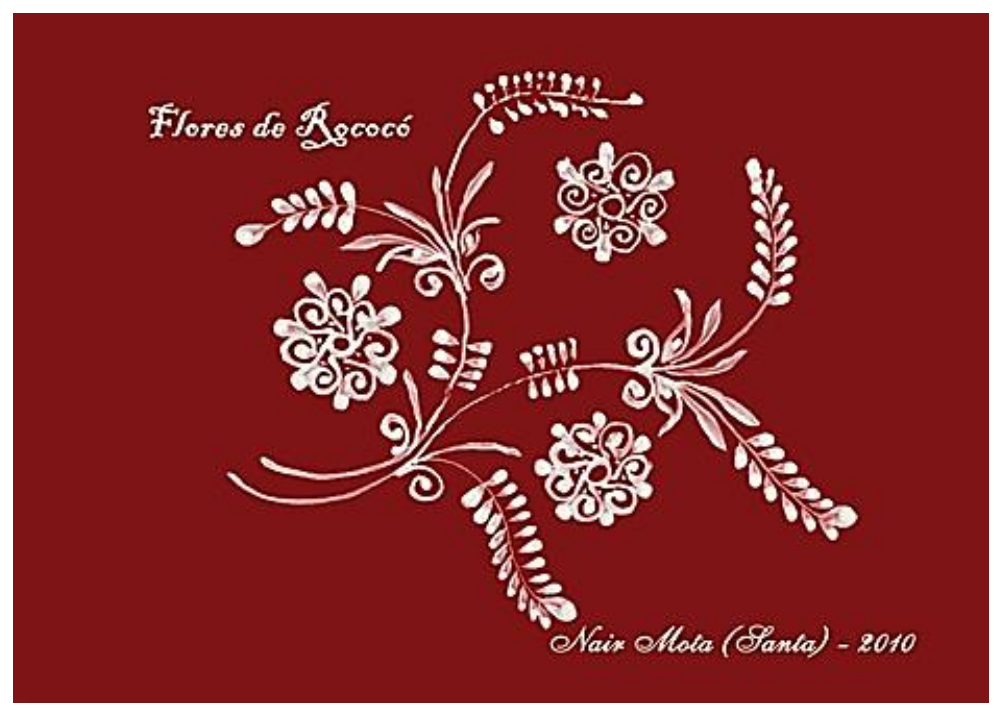

Pintura com tabatinga em papel, Dona Santa, 2010 (Ferraz, 2011, p.76)

Percebi na velha mestra o descanso de quem já tinha cumprido a sua parte. As filhas Neusa e Nailse, depositárias do legado da mãe, davam continuidade ao trabalho com pintura:

Ela é muito boa [apontando para Neusa], não é porque é minha filha não, mas pinta bonito mesmo. Hoje ela tá pintando melhor do que eu. 


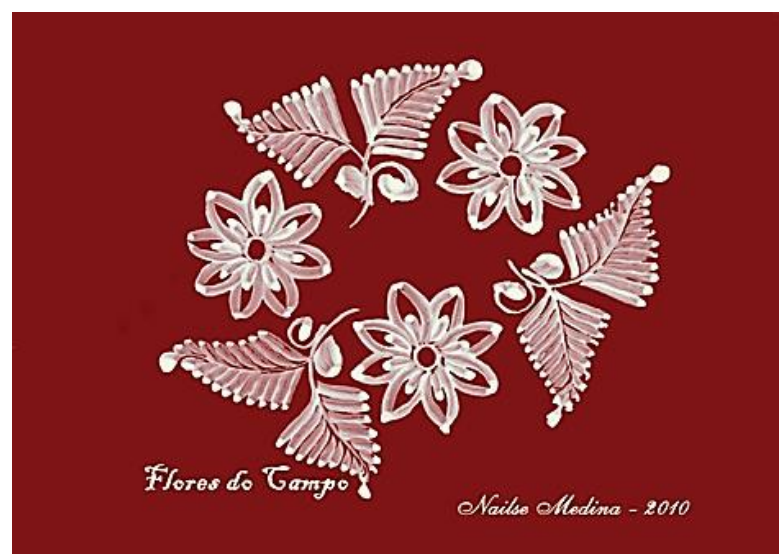

Pintura com tabatinga em papel, Nailse Mota , 2010

(Ferraz, 2011, p.104)

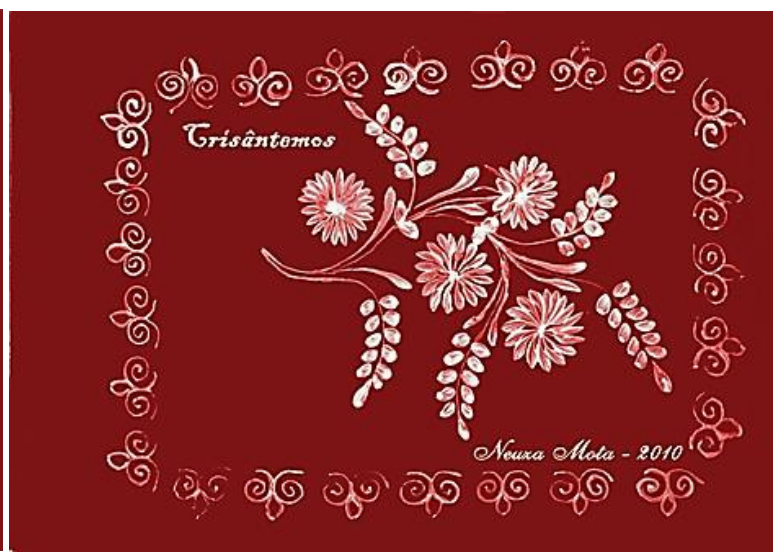

Pintura com tabatinga em papel, Neusa Mota, 2010 (Ferraz, 2011, p.88)

Soube também que Dona Santa é excelente cozinheira. Ela se desculpou várias vezes por não ter me convidado para saborear o almoço tradicional de Páscoa que havia preparado no sábado de aleluia, dois dias antes da minha visita. Foram servidos pratos típicos da cozinha baiana: camarão, vatapá, caruru, moqueca de siri catado. Fui embora com água na boca e com a promessa de que, em nosso próximo encontro, iria provar um prato preparado por ela. 


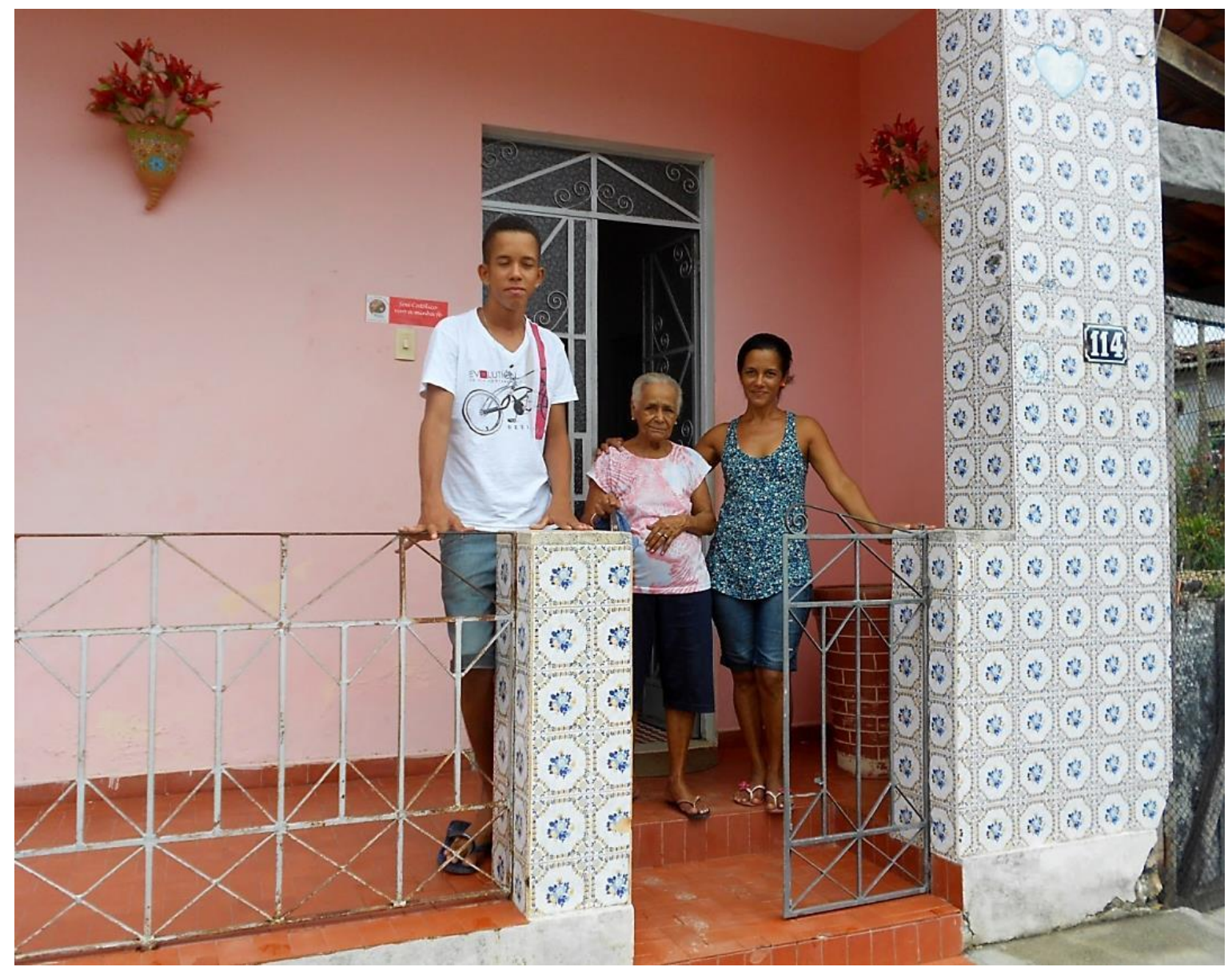

Isaac, Dona Santa e Neusa 


\subsubsection{Rozalvo}

Rozalvo Santana, Rozalvo Santeiro, ou simplesmente Rozalvo, é filho do falecido oleiro Aliordes Santana, o Roxinho. Rozalvo é um dos únicos santeiros de Maragogipinho. Suas belas e suntuosas esculturas religiosas exploram detalhes e nuances dos mantos em múltiplas camadas e dobras, criando efeitos de leveza esvoaçante, típicos do estilo rococó. Rozalvo é reconhecido internacionalmente pelo seu trabalho. Diferentemente da maioria dos artesãos do povoado, ele trabalha totalmente sozinho e assina as suas esculturas:

Hoje, algumas pessoas compram meu trabalho por conta da minha assinatura. Dizem: "Ah, quero se for de Rozalvo".

Conversei com Rozalvo apenas uma vez, em sua casa. Não visitei o seu ateliê porque estava em reformas. A casa onde vive com a mulher e os filhos é simples, pequena, sem forro, contrasta com a magnificência de suas peças. Na frente da casa, me deparei com a saia de um São Francisco de barro, em tamanho natural, secando ao sol, com as mãos separadas do corpo. 

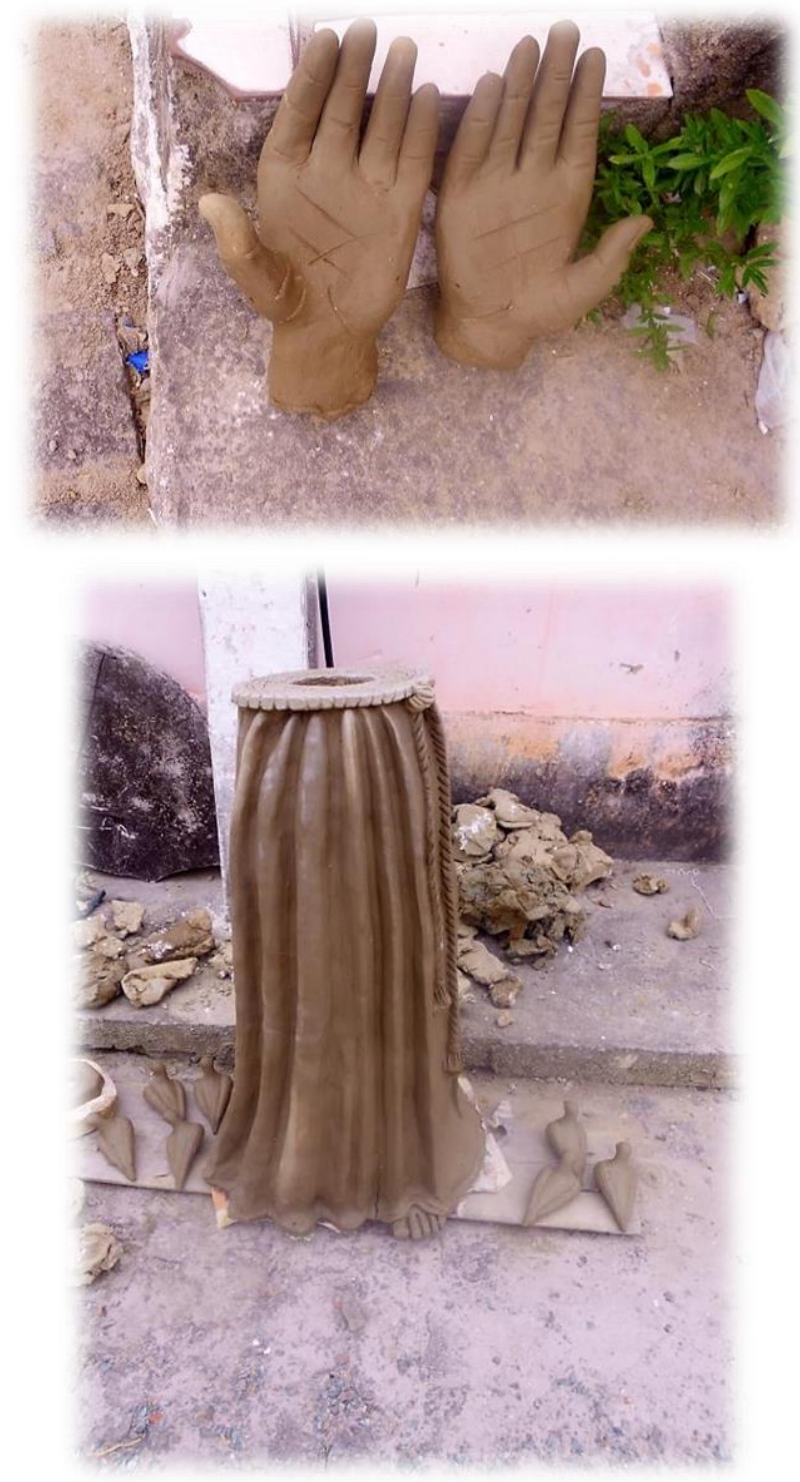

Escultura de São Francisco em processo de construção na frente da casa de Mestre Rozalvo 
À primeira vista, Rozalvo anuncia características semelhantes aos dos outros homens de Maragogipinho: o corpo é pequeno e forte, tem a voz suave, os gestos refinados e me recebeu com simpatia e cordialidade.

Suas

singularidades irromperam das histórias que me contou sobre a sua trajetória no barro:

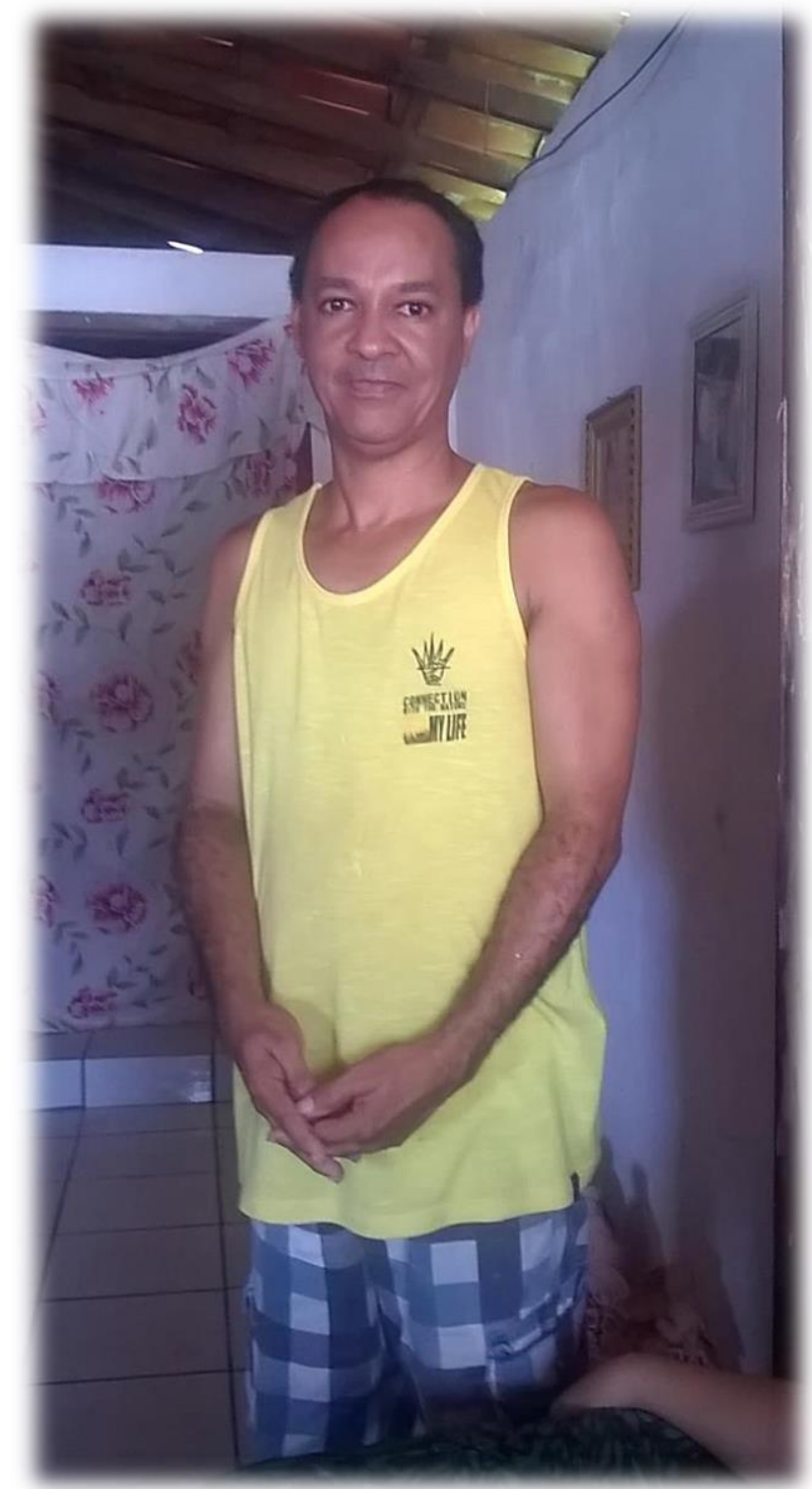

Mestre Rozalvo em sua casa 
Quando eu tava com 15, 16 anos uma pessoa me falou se eu poderia fazer um santo. Eu disse: "eu nunca fiz", mas só que por uma escultura que eu já tinha feito a pessoa viu e disse: "você faz, só precisa fazer a iconografia. Porque o rosto das peças é um rosto bonito. Então você precisa dar uma direção à escultura". Então eu comecei, fiz um teste, fiz uma Nossa Senhora da Conceição de $60 \mathrm{~cm} .60,70$. Era a primeira, nunca tinha feito. E aí ficou uma coisa bonita pra época.

Então, ele levou a peça da santa para a Feira de Caxixis, em Nazaré das Farinhas, onde as pessoas não costumavam ver santos, pois os objetos expostos eram utilitários e caxixis. Ele conta que veio muita gente observar a sua escultura de Nossa Senhora da Conceição, ela fez realmente sucesso.

Eu só fui ver o que eu tinha feito pela narração das pessoas.

Com o manuseio, na Feira, a peça acabou danificada, mas foi vendida mesmo assim. Dessa maneira, Rozalvo iniciou a carreira de santeiro, que já dura mais de 30 anos. Como não teve mestres em Maragogipinho, sua narrativa tece um discurso de quem galgou o aprendizado autodidata, de quem inaugurou uma modalidade expressiva na tradição cerâmica da comunidade. Desenvolveu várias técnicas de modelagem e de queima por tentativa e erro, entre outros caminhos. 
Quando eu ia fazer uma santinha destas, só pra fazer os cabelos eu levava uma manhã. 'Mas eu não vou poder ganhar dinheiro com isto, eu demoro demais!' Então fui descobrindo o que é a prática, a prática faz a gente ser rápido. Começa a pegar a prática das coisas, começa a desenvolver a velocidade. Hoje eu boto cabelo em quatro ou cinco peças em uma manhã

A confecção de suas esculturas requer um lento processo. A modelagem começa a partir de um cone, a peça sempre é oca. Para fazer os pequenos detalhes dos olhos, cabelos e volumes das roupas, Rozalvo usa como ferramentas a espinha dorsal do peixe arraia, arame e palito. Depois de pronta, a escultura começa secando na sombra e depois vai para o sol, durante mais ou menos

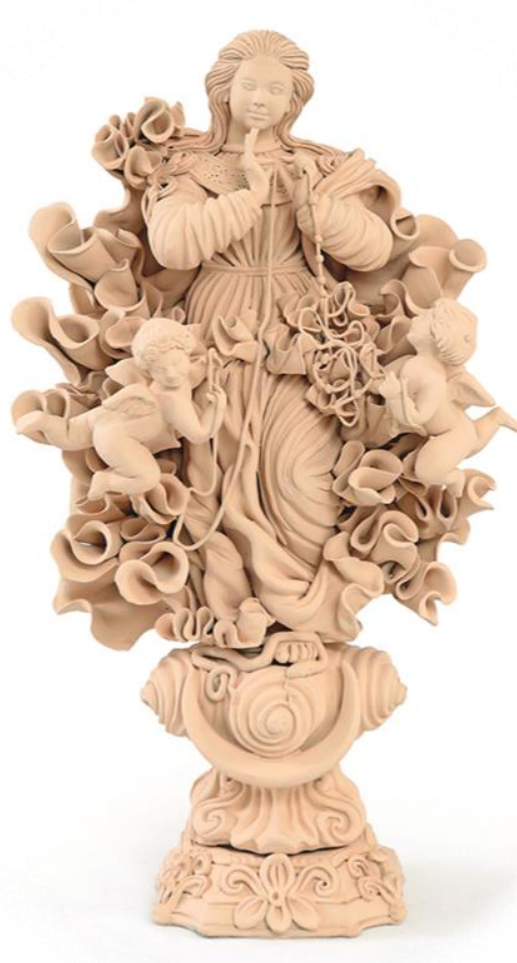

Escultura em barro de Rozalvo Santana

http://casa.abril.com.br/materia/a-mostra-arte-popular-brasileira-apresenta-

obras-de-artistas-de-raro-talento 
uma semana. A queima dura de 18 a 20 horas no forno a lenha. A produção da imagem leva, no total, uns quinze dias.

Se a natureza leva não sei quantos anos pra transformar a argila em pedra, por que vou eu querer petrificar uma argila em somente oito ou dez horas? Muita pretensão da minha parte, né? (...) Sempre devagar pra poder atingir a perfeição (Rozalvo).

Essas palavras do artesão, dignas de um mestre do barro, lembraram-me da frase de um chefe indígena seatle, divulgada pela ONU em 1954: "A terra não pertence ao homem; o homem pertence à terra".

\subsubsection{Nené}

Conheci Nené na minha segunda visita a Maragogipinho. Tinha ouvido falar dele por outros oleiros e havia visto imagens suas e de seus trabalhos no livro "Em nome do autor" (Lima, 2008). Nené me recebeu em sua olaria numa tarde de calor. Descalço, estava desenfornando umas peças, havia acabado de abrir o forno e retirava os objetos ainda mornos. Imediatamente, parou o que estava fazendo e, com vontade de conversar, me atendeu calmamente. 


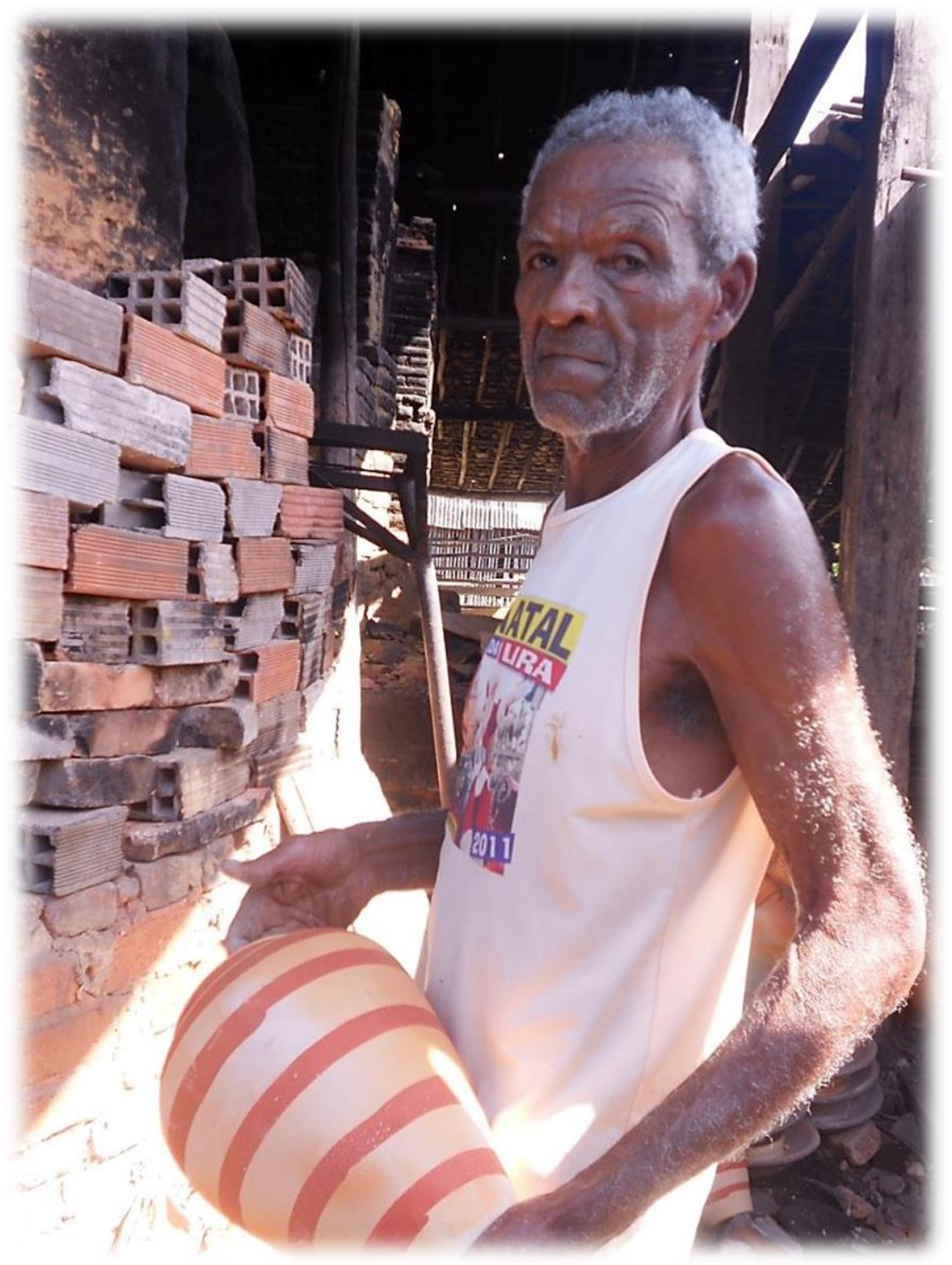

Mestre Nené 
Havia outros homens trabalhando na olaria, que sorriram respeitosamente para mim e continuaram seus afazeres. Nessa ocasião, conversei mais ou menos duas horas com Nené, tempo em que esteve totalmente disponível, não se preocupando em retomar o trabalho. Seu acolhimento trouxe conforto e descontração para o nosso diálogo. Depois daquele dia, voltei mais duas vezes à sua olaria e, como sempre, parou de fazer seu trabalho para me receber.

Batizado como Elísio Nazaré Almeida, Nené tem 75 anos, é moreno, magro e forte. Assim como quase todo oleiro de Maragogipinho, aprendeu a tornear ainda criança, com o seu avô: Cláudio Manuel Nazaré. Sereno, de voz macia, Nené me ensinou bastante, principalmente sobre queimas e misturas de barros.

Tem a prática e tem a teoria. Na prática, existe o barro gordo e o barro magro. Na teoria, existe o barro ariento e o barro liso. $\mathrm{O}$ ariento tem uma areiazinha e o gordo é liso que parece um sabão. A senhora pega assim e ele vai escorregando. Sozinho, nenhum dos dois presta. Tem que misturar, dependendo da peça que se vai fazer (Nené). 
Enquanto explicava, ia desenhando na bancada do torno com um pedaço de carvão. Perguntei bastante, ele didaticamente respondeu a todas as minhas questões.

"O senhor sabe muita coisa, Seu Nené, o senhor possui uma sabedoria", falei em certa

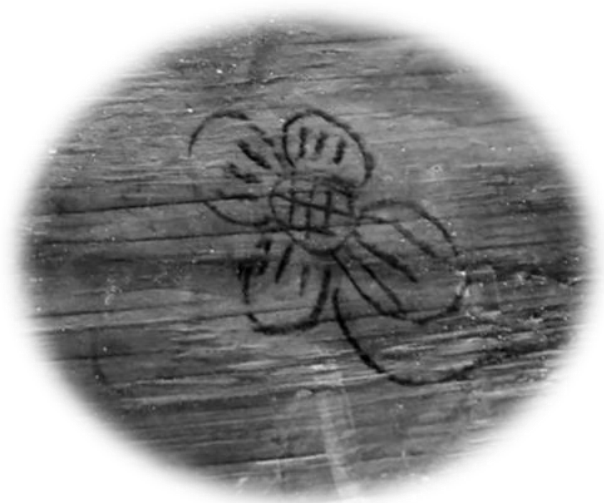

Desenho de Mestre Nené altura. Ele riu e respondeu com simplicidade:

\section{Ainda sou aluno!}

Conversei com Nené sobre o processo de vitrificação das peças utilitárias com chumbo e dos possíveis danos que causam à saúde:

Olhe, particularmente eu não posso discordar porque quem estuda é que sabe de tudo. Agora, só que a população toda daqui foi criada com isso. Se fazia feijão na panela vidrada, se fazia moqueca na panela vidrada e até hoje ninguém teve nada. Eu mesmo não tive. Não vou dizer que tá errado. Os homens que estudam é que sabem. 


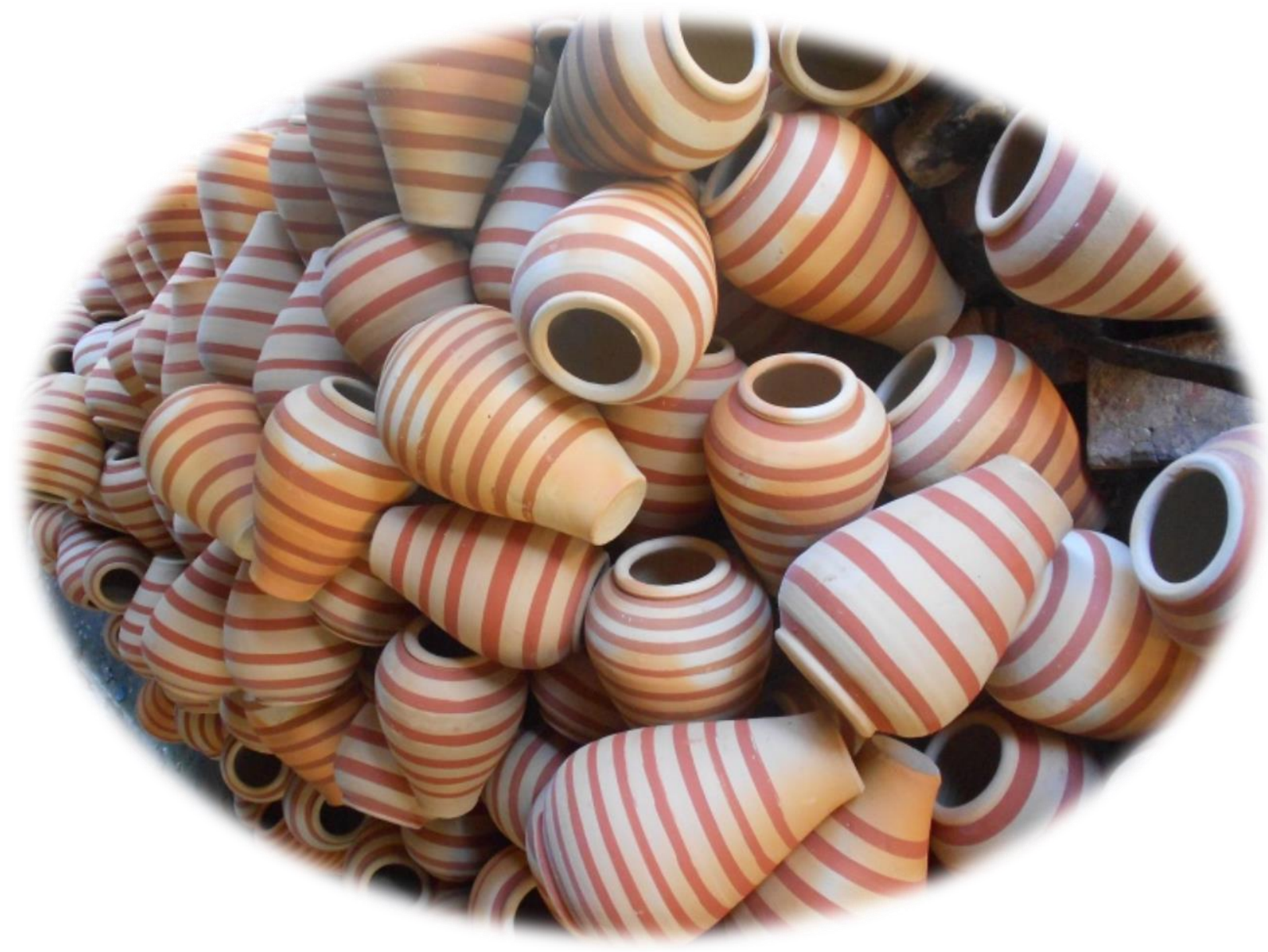

Porrões recém-desenfornados na olaria de Mestre Nené 
Nené faz todo o tipo de peça e executa quase todas as atividades do processo produtivo: do torno à pintura da peça. Ao seu lado, experimentei um sentimento de admiração pela profunda sabedoria que enxerguei em sua simplicidade. A olaria se localiza em um ponto estratégico no caminho entre as olarias. Passei por lá diversas vezes e, sempre que nossos olhares se cruzaram, recebi dele um sorriso franco.

\subsubsection{Padre}

A primeira vez que entrei na olaria de Padre, fiquei encantada com a quantidade de peças elaboradas à moda tradicional: pintadas com tauá e tabatinga. Grandes objetos vermelhos com detalhes em branco se perfilavam pelos corredores da olaria, cuidadosamente arrumados, alguns cobertos por plásticos.

Padre me havia sido recomendado como o oleiro mais "conservador" de Maragogipinho, fazia questão de produzir seus objetos somente ao modo tradicional. A beleza dessas peças, todas juntas, era gritante, fiquei grata por ter podido apreciá-las. "Padre, você tem aqui um verdadeiro tesouro!" 


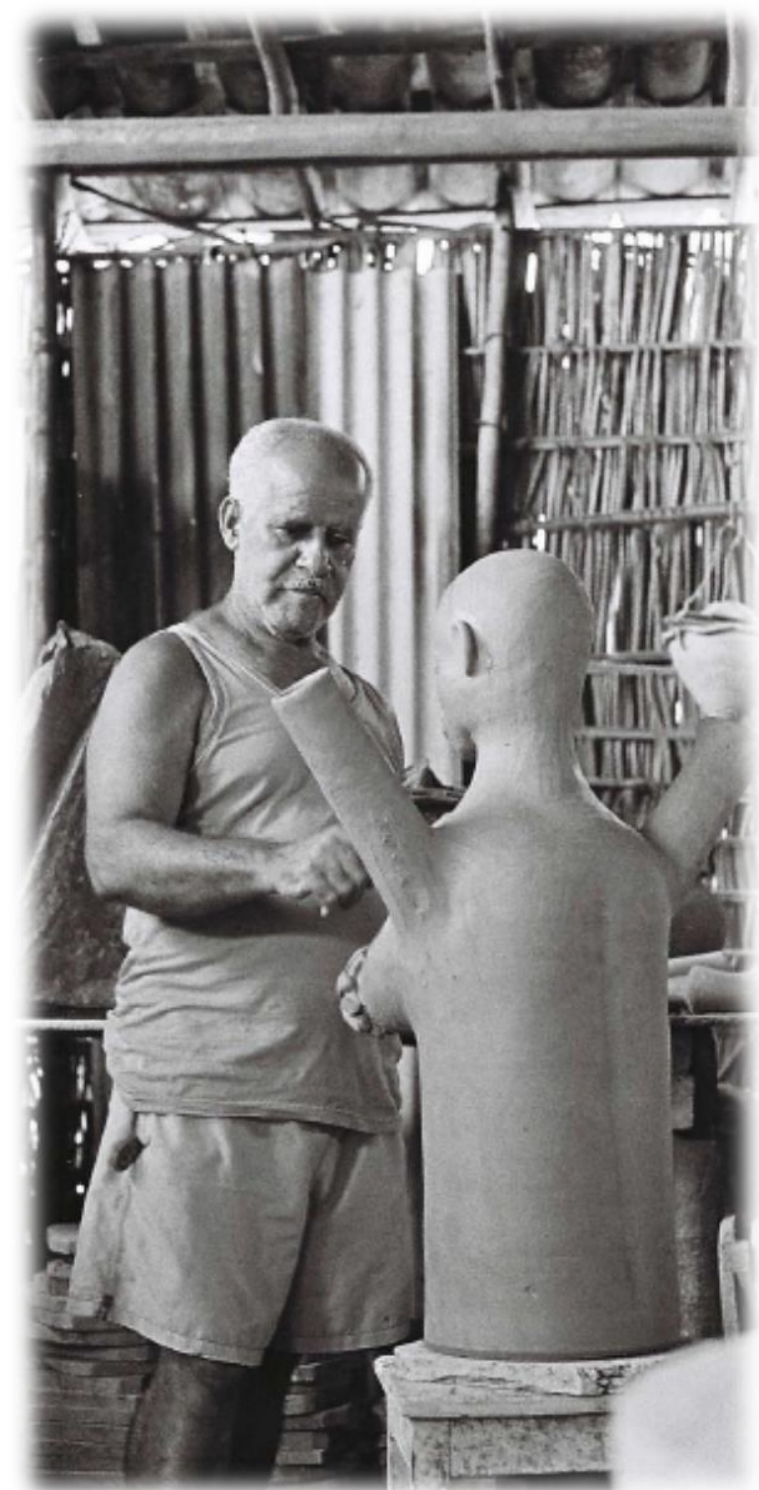

Antônio Santana Moreira Costa é apelidado de Padre, porque, segundo ele, trabalhou durante a adolescência na igreja católica. Não foi seminarista, ajudava na missa. É sobrinho de Mestre Vitorino e aprendeu o torno com seu pai: João Pascoal Costa.

Aos doze anos, comecei a chutar o torno.

O sotaque baiano, o jeito manso e a disponibilidade para conversar são também características desse oleiro. Aos 65 anos, mostra-se preocupado com a continuidade da linha tradicional da cerâmica de Maragogipinho. Sua olaria é um verdadeiro reduto de resistência. 
Aqui, só quem trabalha cem por cento com a linha tradicional sou eu.

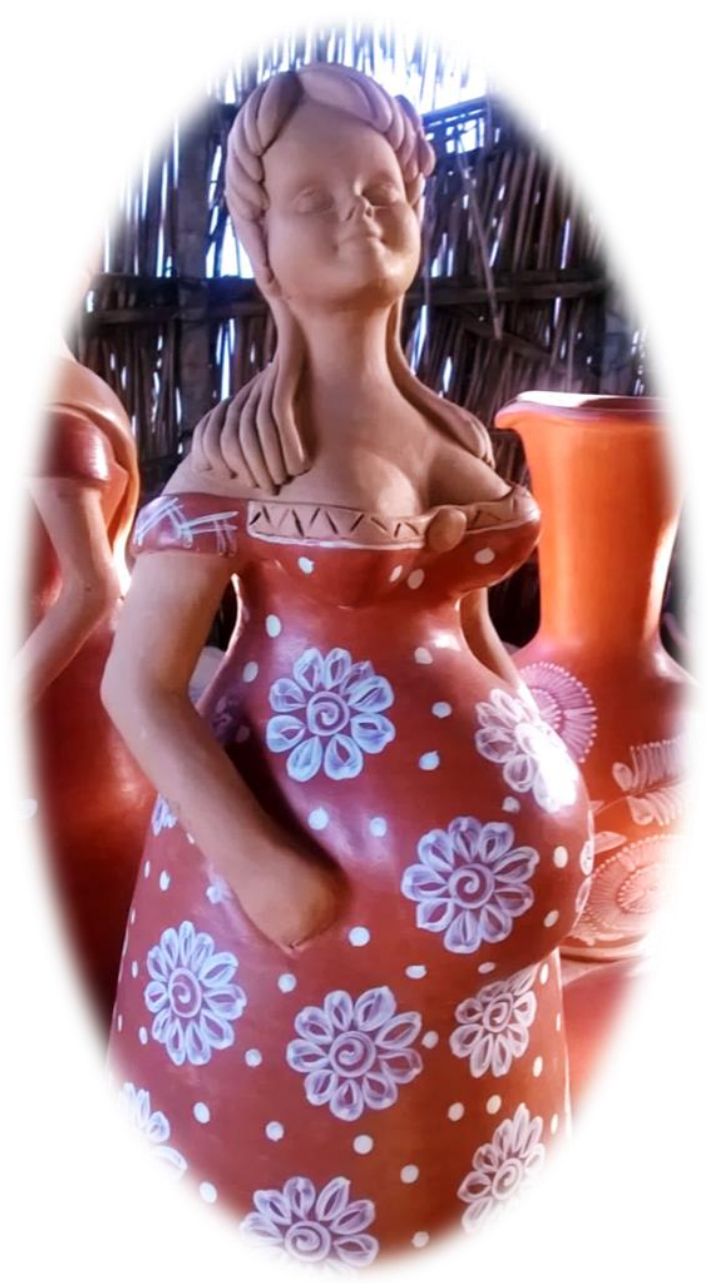

Boneca na olaria de Mestre Padre 
Em meio ao acervo de peças tradicionais, uma se destacava pelo tamanho, pela ausência de pintura, pelas formas arredondadas e pela expressão plácida. Era um boi com a cabeça e os chifres abaixados, de corcova saliente. $\mathrm{O}$ boi fora encomenda de uma professora para uma escola em Feira de Santana. Ela mesma pediu que os chifres não ficassem salientes para não ferir as crianças e não correr riscos de quebrar. Para entregar um boi, Padre teve de fazer três bois. Felizmente, nenhum fora danificado pela queima.

Padre trabalha praticamente sozinho. Contrata apenas um amassador para pisar e amassar. De resto, torneia,

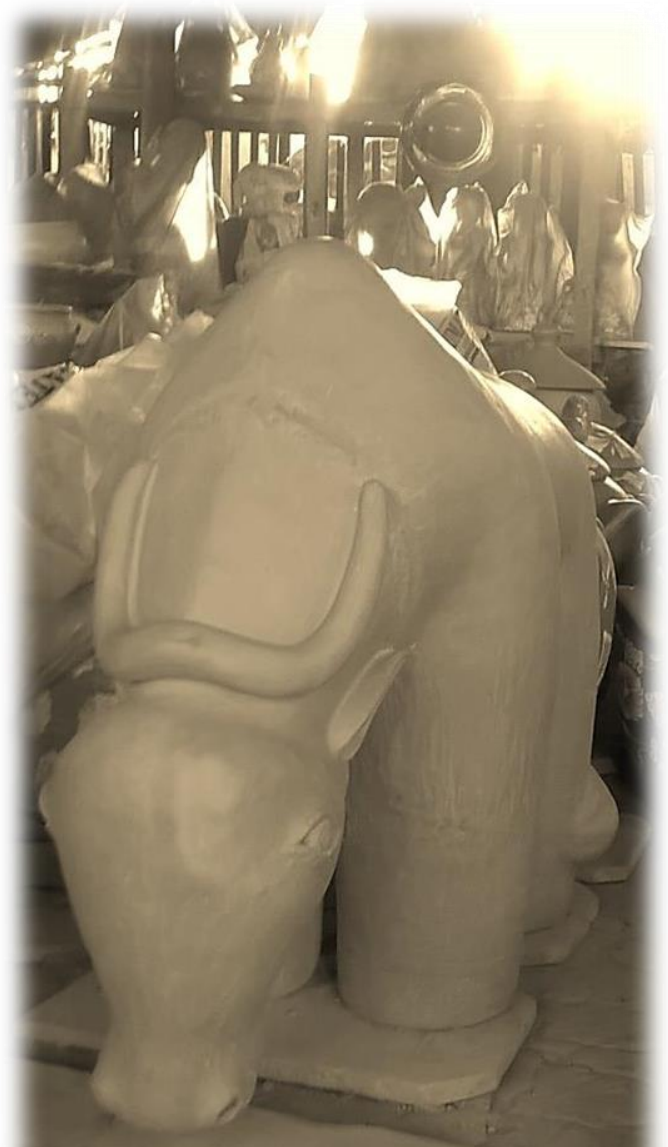
emenda, queima e desenforna as suas peças. A pintura, geralmente é realizada pela sua filha, mas também faz encomendas para pintoras da comunidade. 
O trabalho de Padre é primoroso. Todas as etapas da produção da cerâmica tradicional são seguidas religiosamente em suas peças, o que lhe custa um esforço árduo, já que atualmente não dispõe da quantidade ideal de trabalhadores na cadeia produtiva. Dono de todo este mérito, protagonizando um verdadeiro mestre do patrimônio cultural imaterial brasileiro, Padre revela desesperança:

Eu já tive muitas, mas muitas pintoras. Já tive muitas burnideiras, e elas se foram. Não existem mais. Esta geração nova que tá aí não quer nada. Eu acho que em Maragogipinho a cerâmica tá se acabando. E vai se acabar.

Neste início do século XXI, a luta e o afinco de Padre por manter a tradição são louváveis. O refinamento e a contemporaneidade convivem em harmonia nas suas lindas peças. Entrevi em Padre o verdadeiro sentido da palavra artesão.

\subsubsection{Zelita}

Antes de conhecer Zelita, havia visto a sua pintura na Feira dos Caxixis, nas peças de Padre, de Seu Zé, de Tutuna, seu marido. Ela realiza uma pintura diferenciada, minuciosa, de traço firme e ao mesmo tempo delicado. 


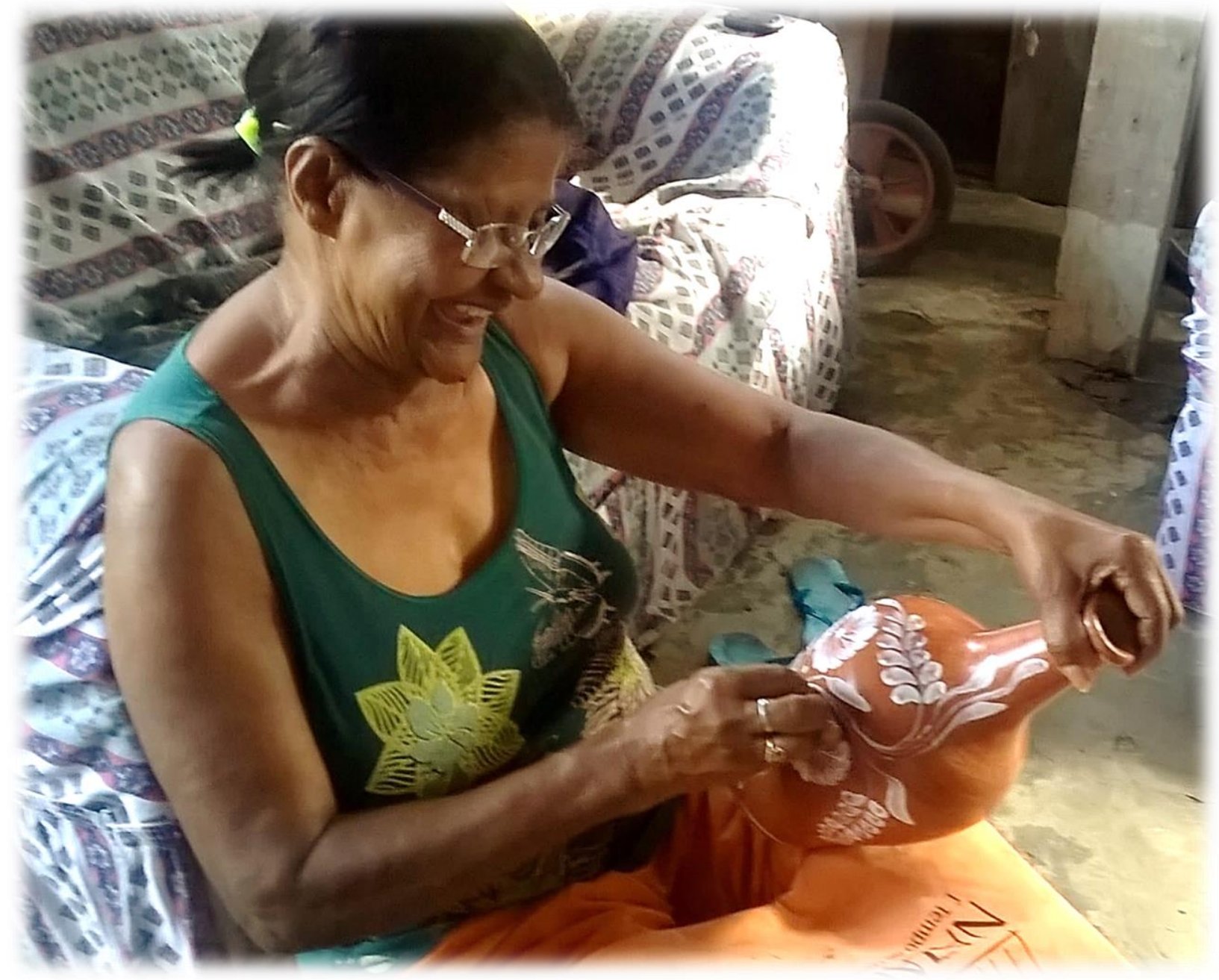

Mestra Zelita pintando

Joselita da Silva Santana tem 68 anos e leva mais de meio século como pintora: 
Pinto desde os 12 anos. Pintava com tinta a óleo, aprendi com Dilva. Depois que me casei, aos 22 anos, comecei a pintar à tabatinga, observando minha sogra, dona Florzinha. Observava também minha madrinha, Santa, que é irmã de dona Florzinha, a pintar. Mas ficava encantada mesmo era com a pintura de Rosalina, como ela abria os ramos, uma pintura diferente, parecendo um caminho sem fim - não se sabe onde começa e termina o desenho. É uma pintura difícil, mas aprendi direitinho (Ferraz, 2011, p. 27).

Zelita me recebeu em sua casa, seu local de trabalho. Ela e a nora Arleide possuem um espaço nos fundos, junto à cozinha, onde realizam o trabalho de pintura. Eu havia marcado a visita no dia anterior, já estava sendo esperada. Zelita me fez entrar, sentar e começou a preparar um pouco de tabatinga, misturando o barro em pó com água, em um fundo de garrafa pet cortada. Apanhou um pincel de pelo de gato, confeccionado por ela mesma e rapidamente, com destreza prodigiosa, pintou uma moringa. A mão deslizou suavemente sobre a peça vermelha e as flores brancas brotaram como se tivessem nascido do barro. Fiquei impressionada. Em cada finalização de uma pétala ou ramo de flor, acumulava-se um pingo mais grosso do engobe branco. Este pingo branco mais forte confere diferencial à 
pintura com tabatinga; a tinta acrílica, pintada a frio, não imprime o pingo, a pintura fica homogênea.

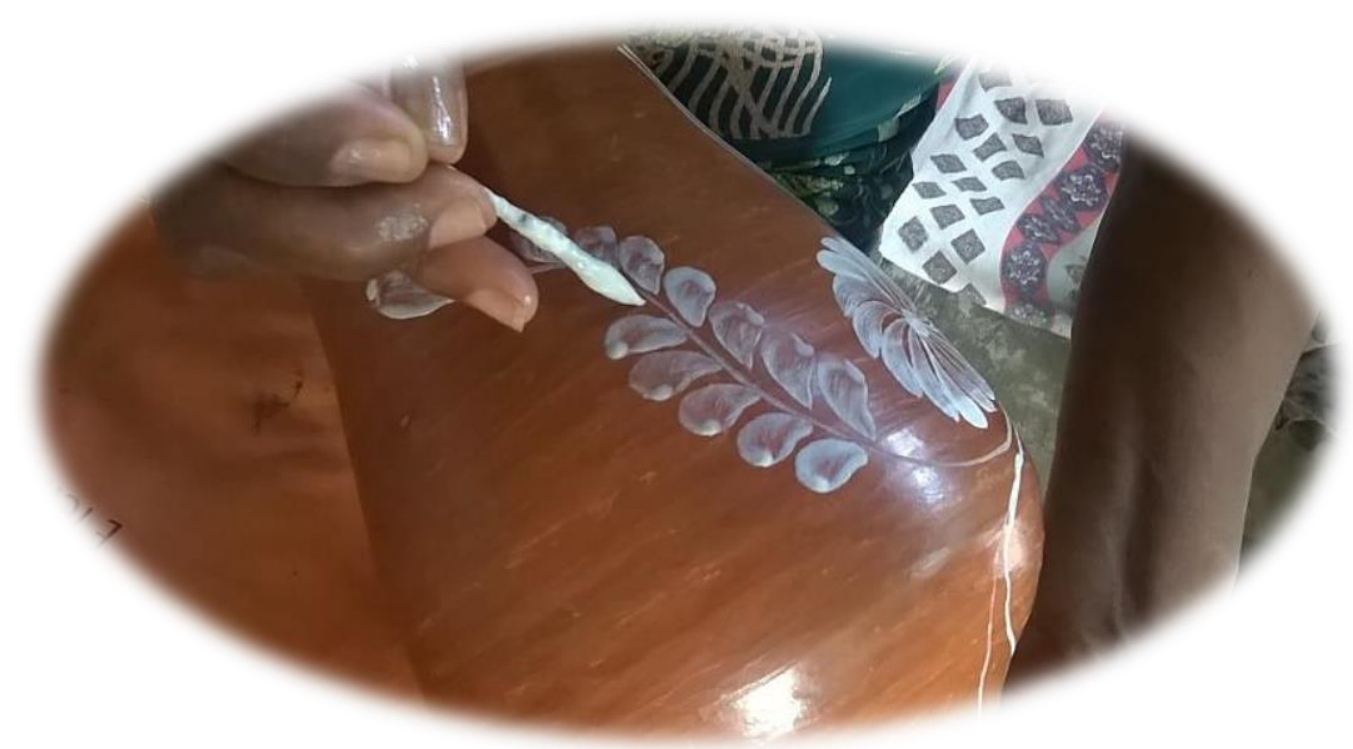

Efeitos de pingos acumulados na pintura com tabatinga

Entretanto, apesar de tanta agilidade e sapiência, Zelita me contou que anda deixando de pintar, tem passado as encomendas para Arleide, sua nora, a quem ensinou: 
Estou cansada, não quero mais pintar, não. Dou os trabalhos pra ela [Arleide].

Só então reparei que a produção de barro que habitava a casa, era quase toda de Arleide. Ela não havia parado de trabalhar desde que eu chegara, modelava umas namoradeiras. Enxerguei a discípula junto da mestra, em silêncio, senti o laço de reciprocidade entre elas.

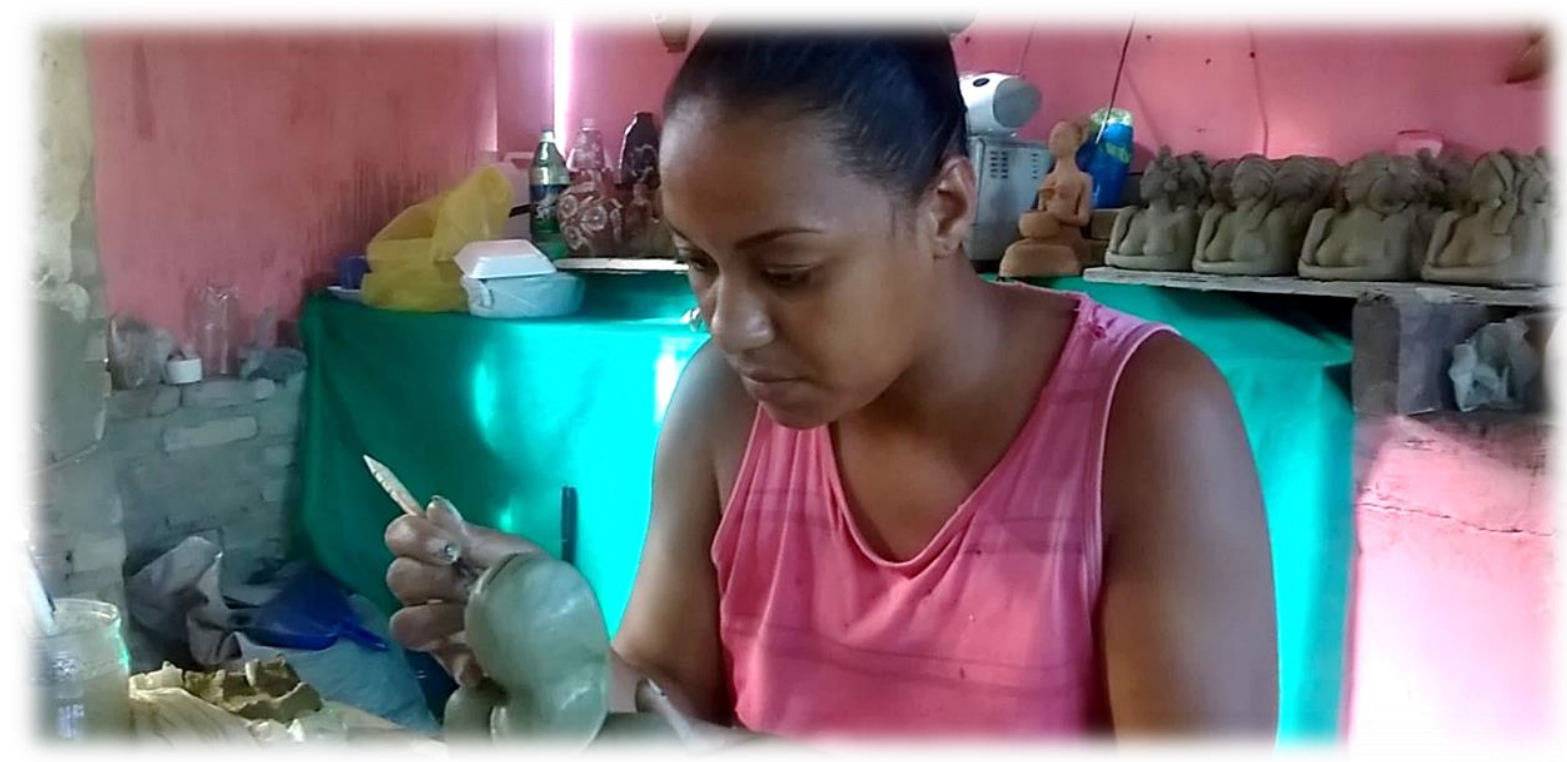

Arleide modelando durante a conversa com Mestra Zelita 
Nora e sogra costumam trabalhar juntas. Elas pintam também a frio, com tinta acrílica. Arleide me explicou que a pintura de certas flores miúdas, como a margarida de pétalas finas, só sai boa se for com tabatinga.

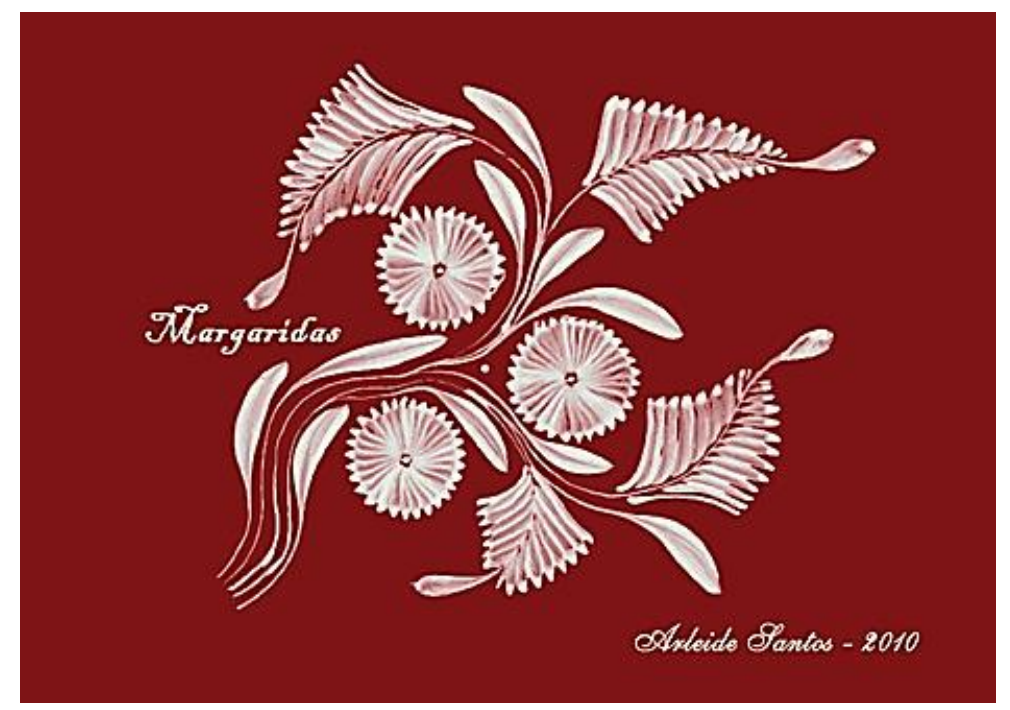

Pintura com tabatinga em papel, Arleide B. Santos, 2010 (Ferraz, 2011, p.39)

No calor da tarde, me foi oferecido um sorvete de fruta. Saboreei com prazer a iguaria gelada, agradecida pelo privilégio de ter convivido com a mestra e a discípula. A mestra, aos poucos, iria retirar-se da cena para que a discípula começasse a assumir a sua maestria, no rumo da partilha dos ofícios tradicionais. 
Ambos [mestre e discípulo] vivem, solidários, a mesma aventura. O mestre foi, aliás, discípulo, e o discípulo, se for digno do mestre, será mestre por sua vez. A educação do gênero humano, no que tem de melhor, prossegue de época para época segundo a exigência renovada desta cultura do homem pelo homem, de mestres para discípulos e de discípulos para mestres. Eis por que, a despeito das especializações que parecem opor as disciplinas técnicas, todo mestre autêntico é um mestre de humanidade (Gusdorf, 2003, p. 193).

Na nossa despedida, Arleide me presenteou com uma linda boneca, modelada e pintada por ela, que, depois de alguns dias, passou a embelezar a minha casa. 


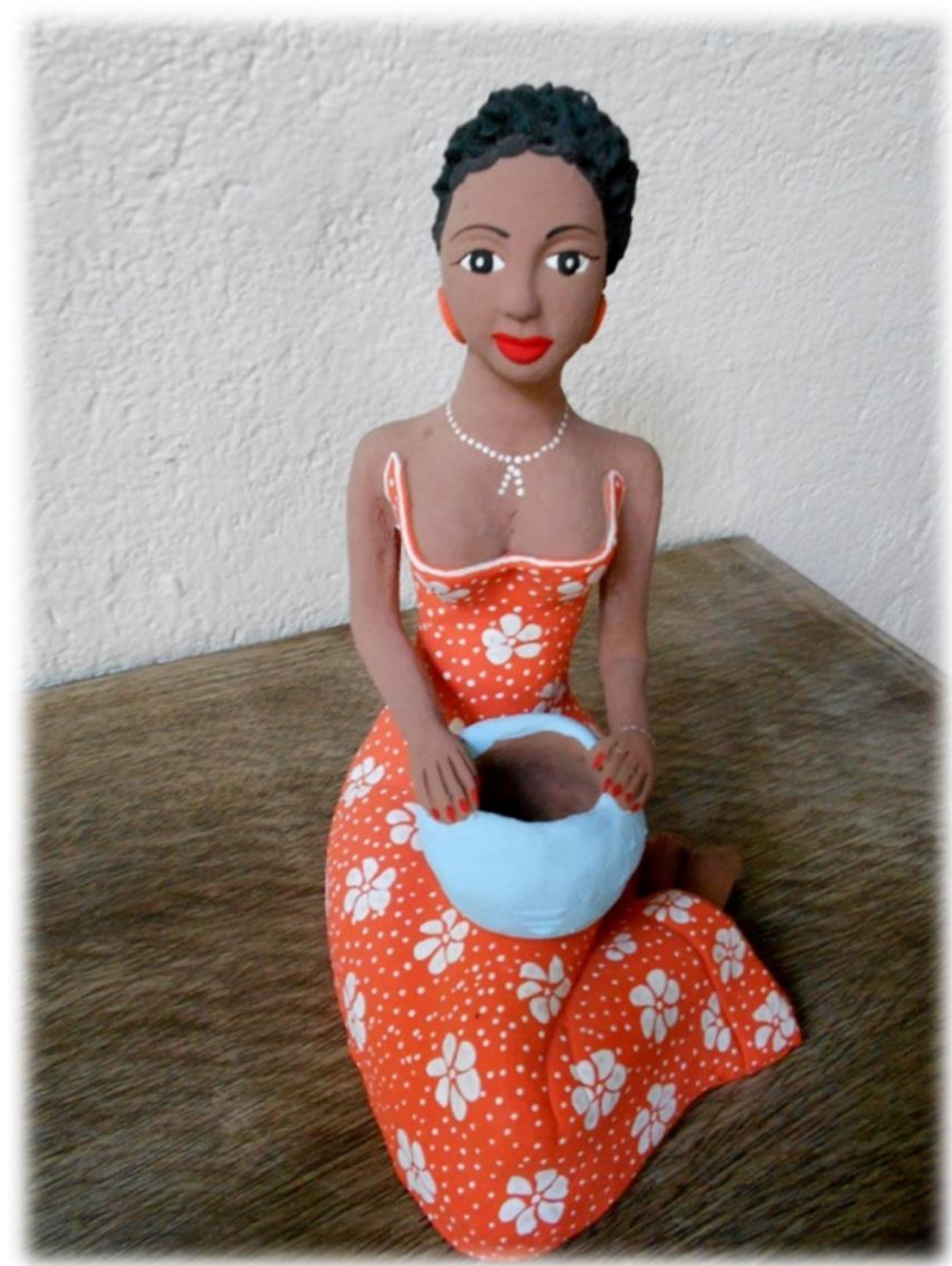

Modelagem de Arleide Brito dos Santos 


\subsubsection{Mais mestres e mestras}

Maragogipinho é uma terra de inúmeros mestres e mestras do barro. Não poderia deixar de citar mais alguns neste trabalho, mesmo ciente de que deixarei outros e outras de fora.

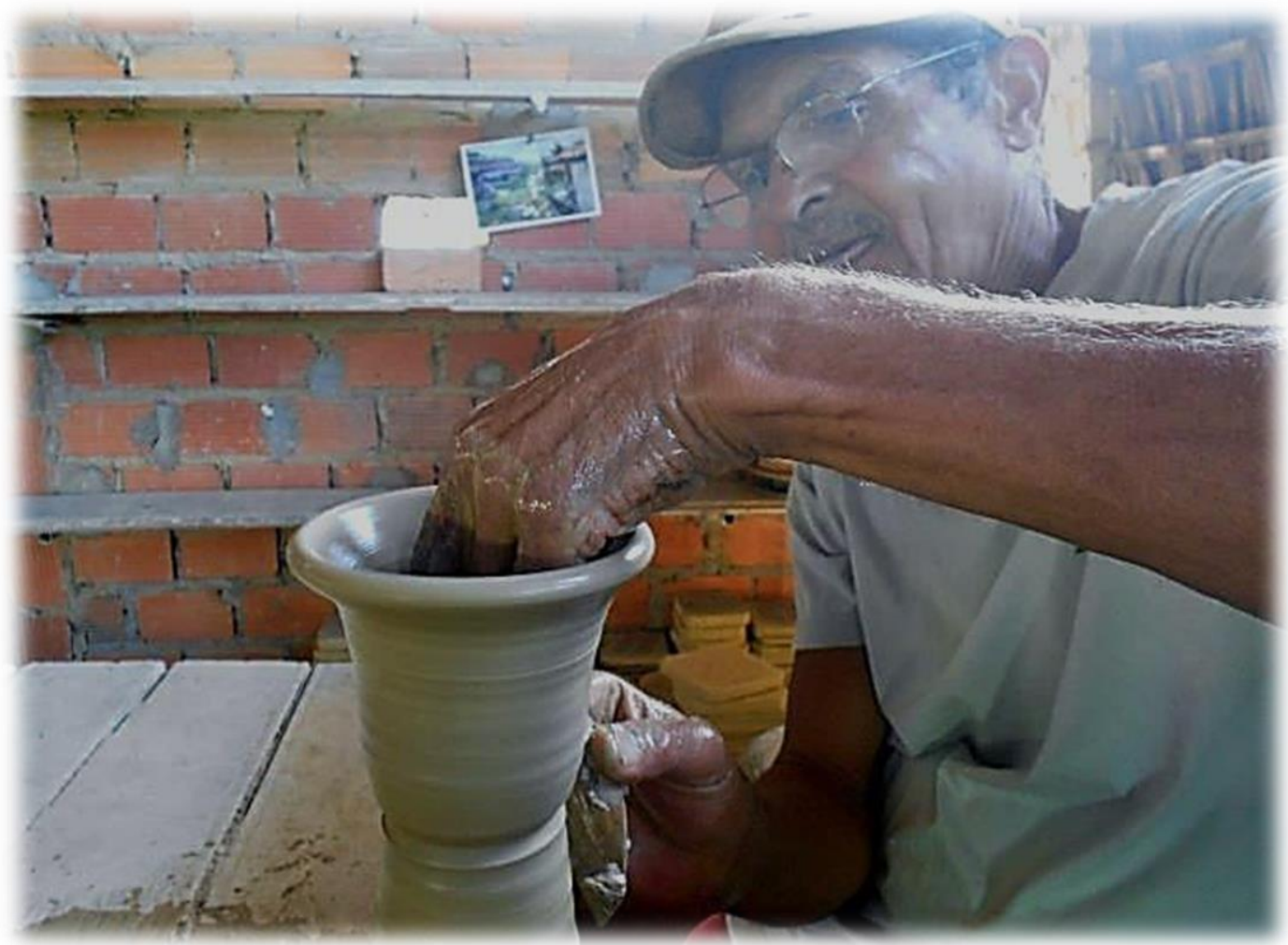

Mestre Zé Curu 


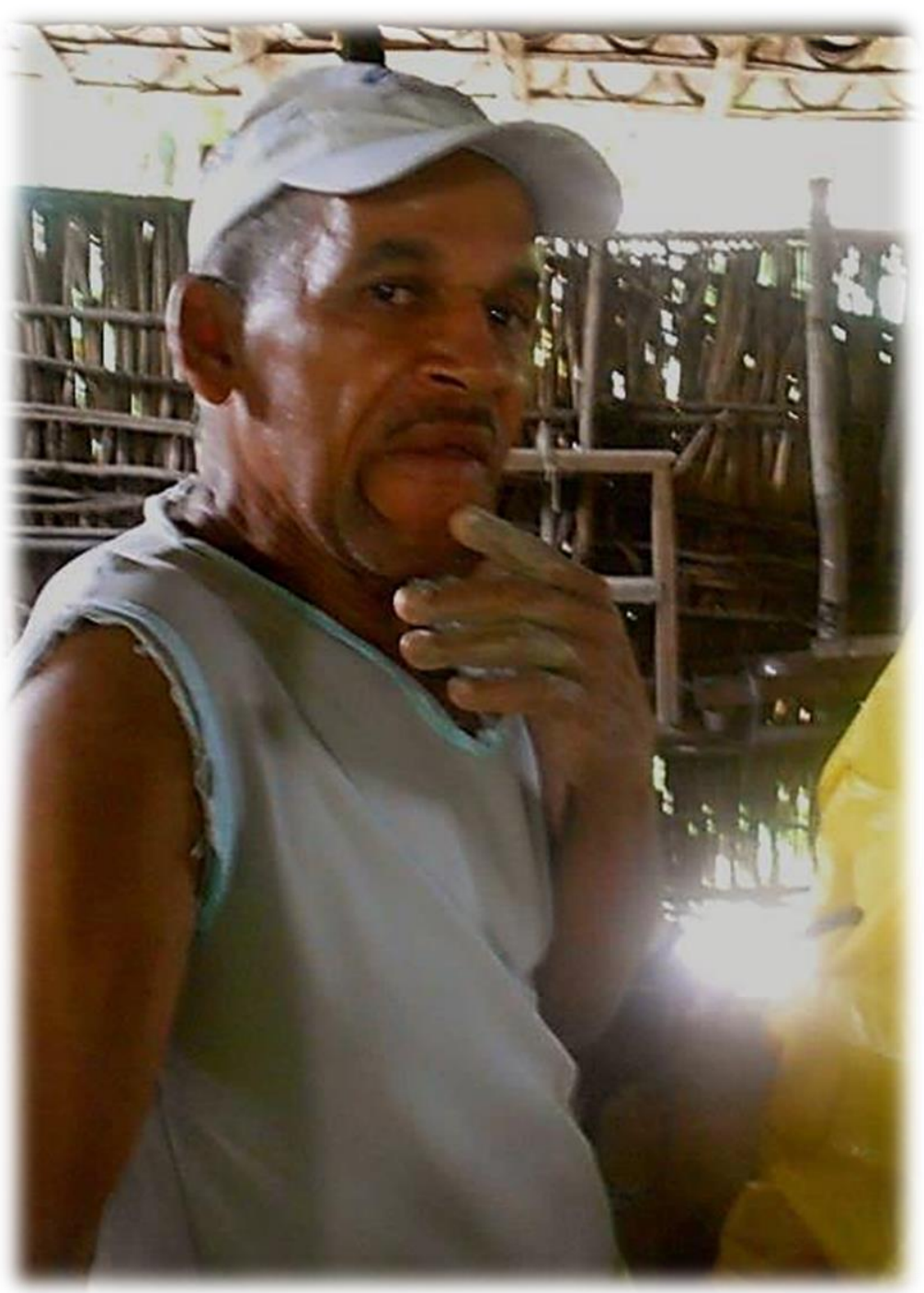

Mestre Tutuna 


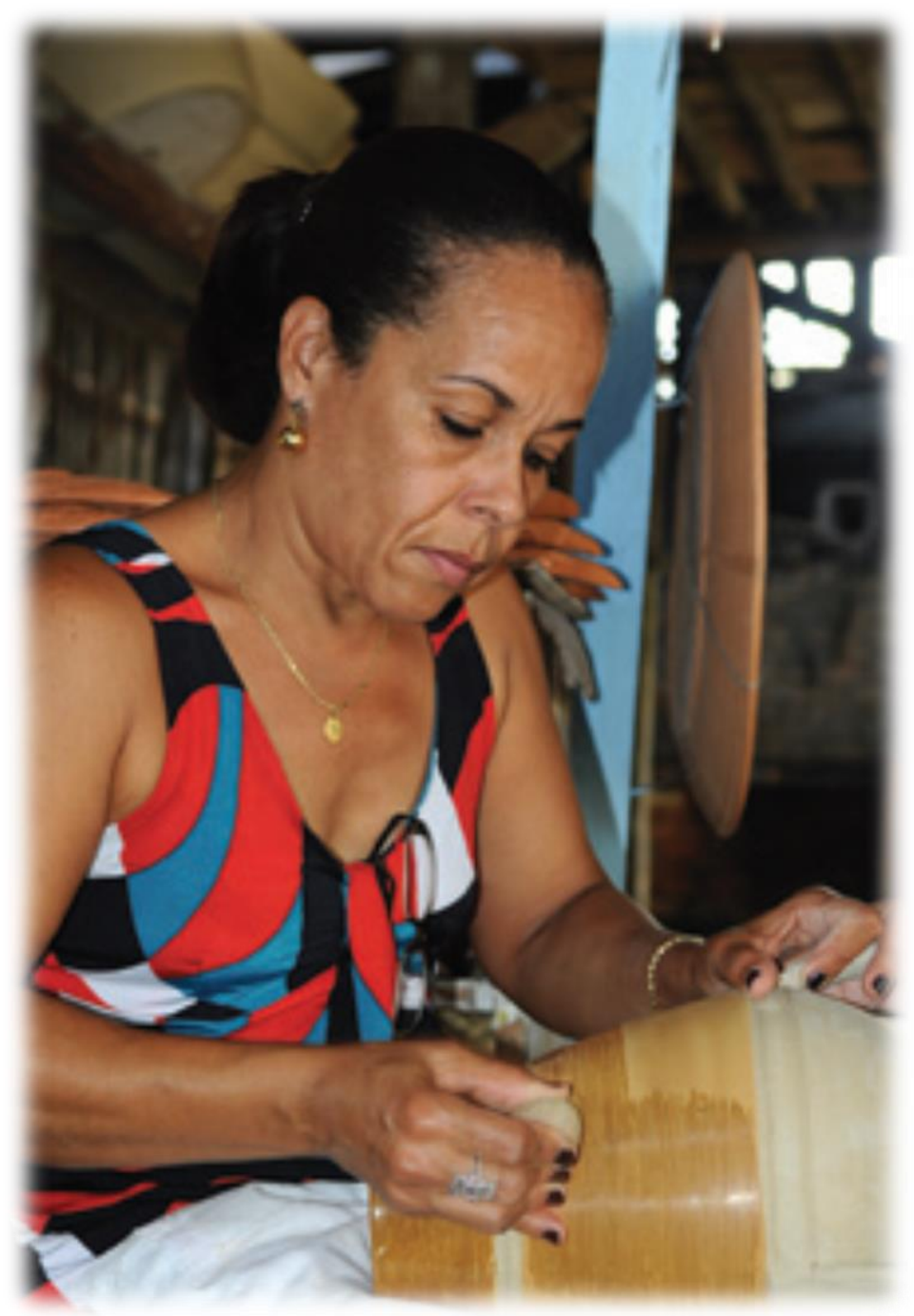

Mestra Nailse

(Ferraz, 2011, p.86) 


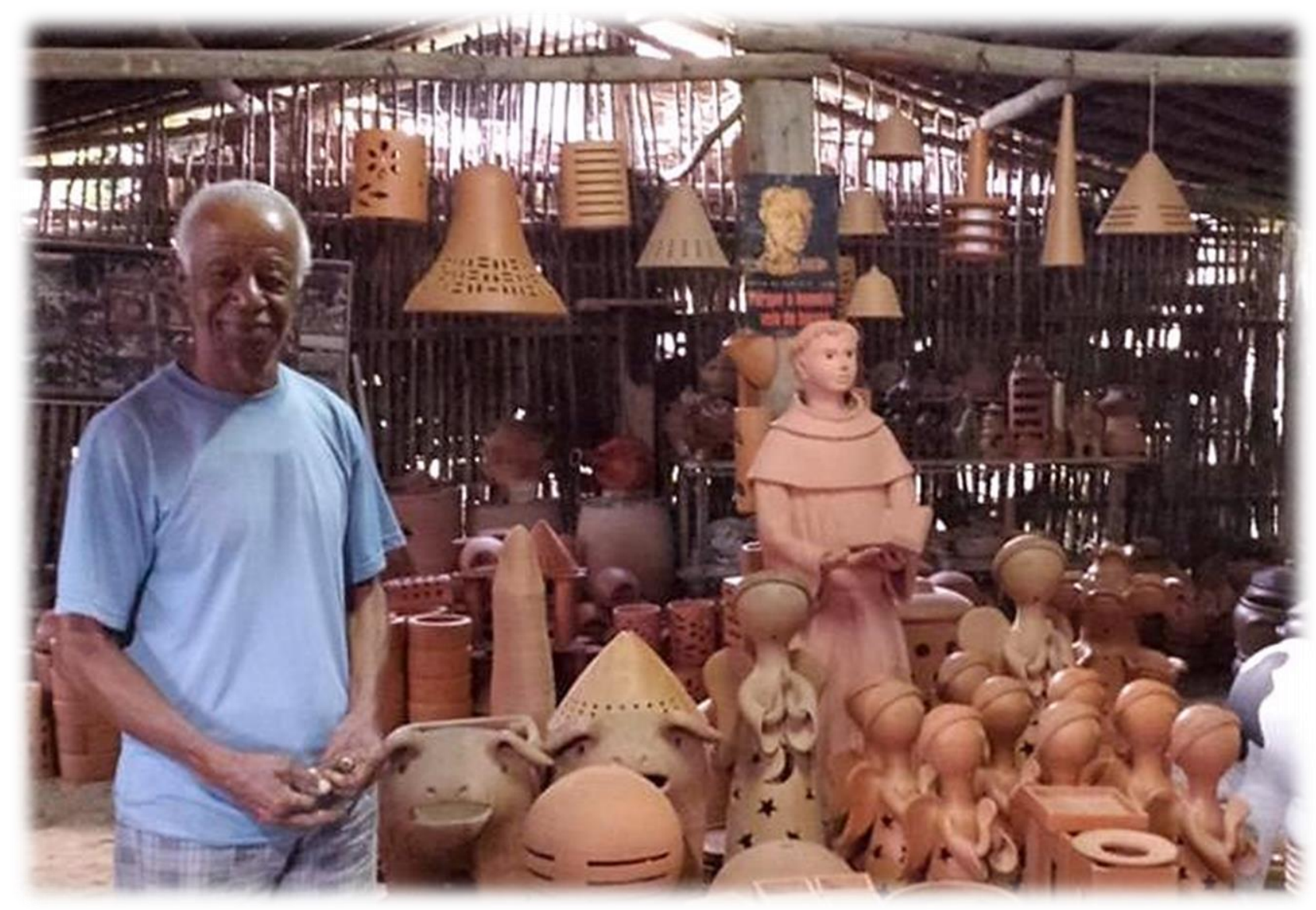




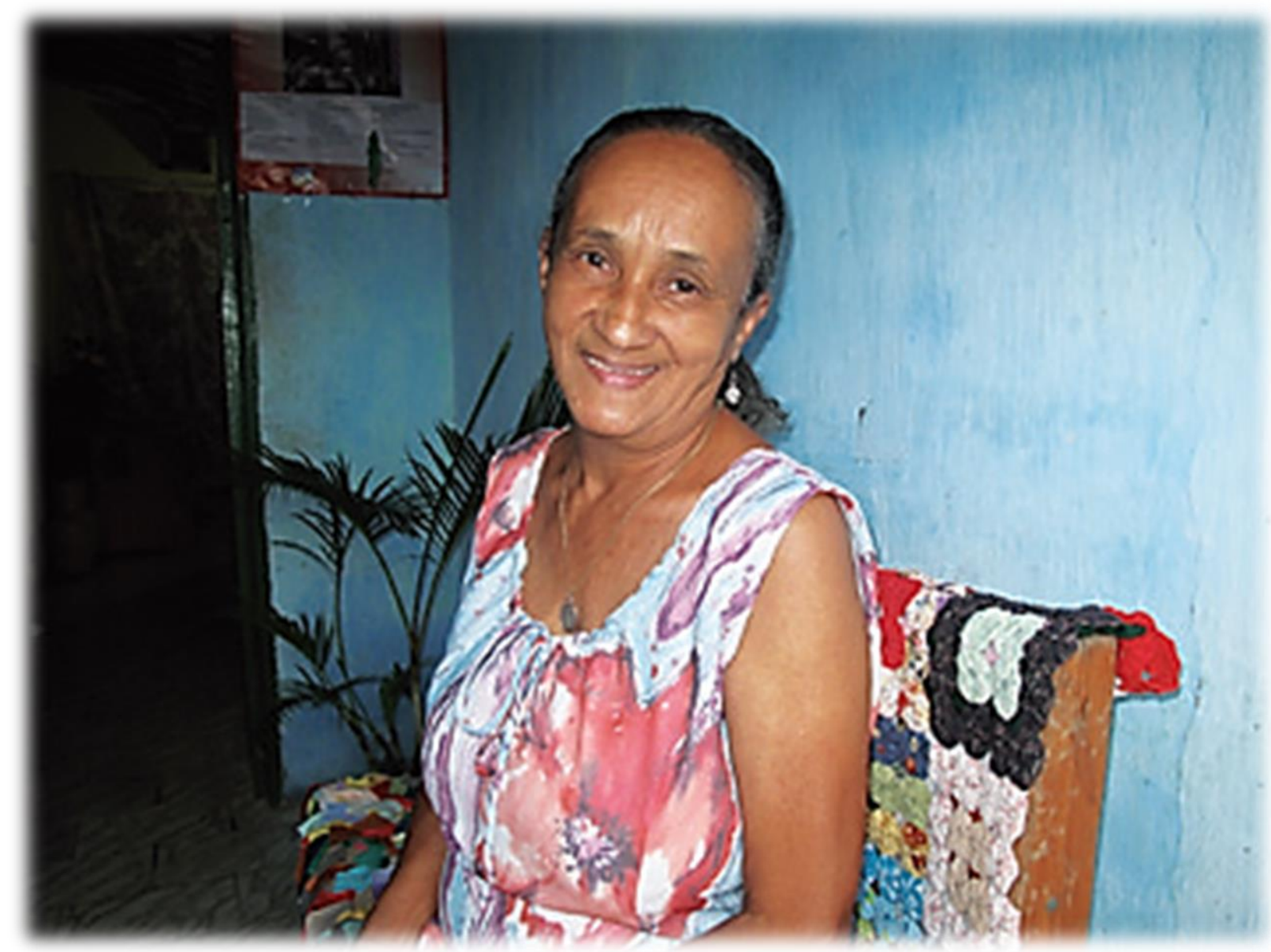

Mestra Mil

(Ferraz, 2011, p.58) 


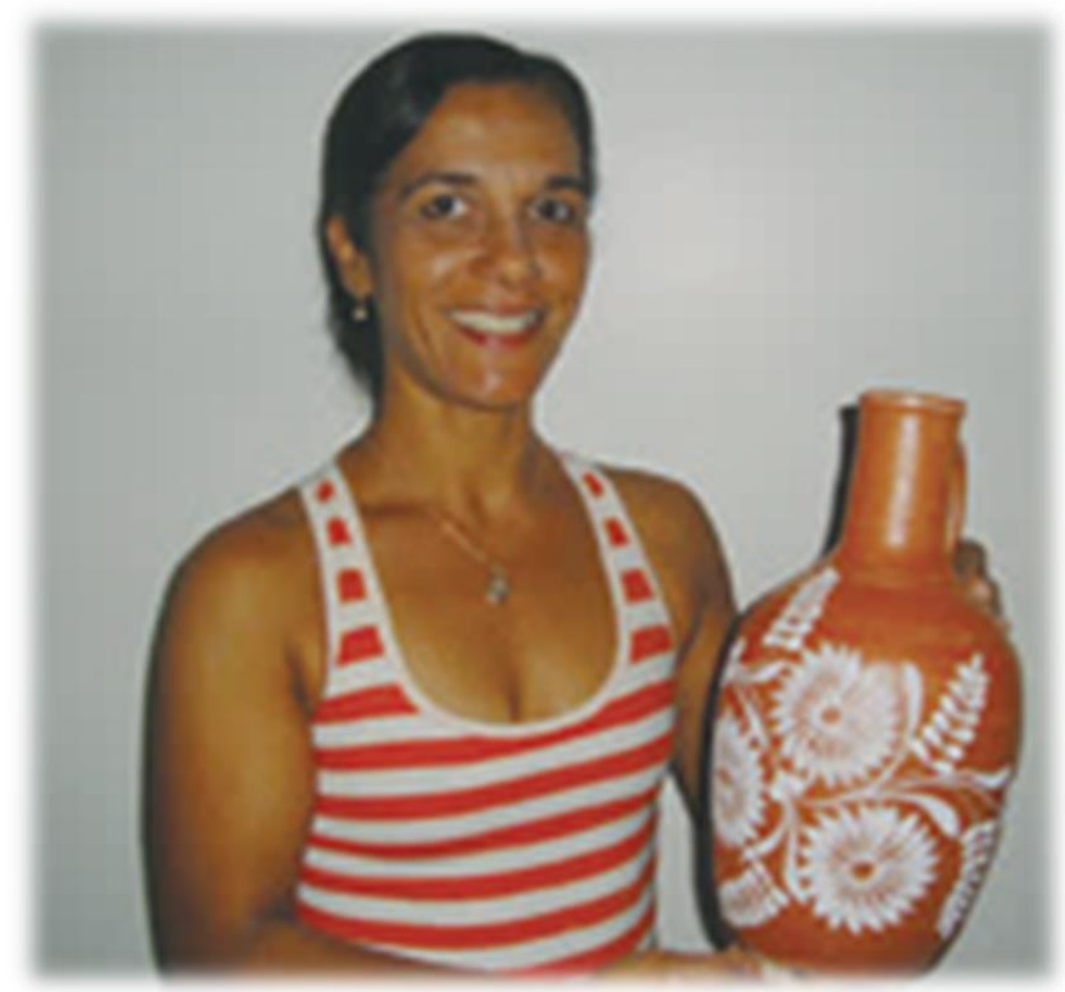

Mestra Neuza

(Ferraz, 2011, p.98) 


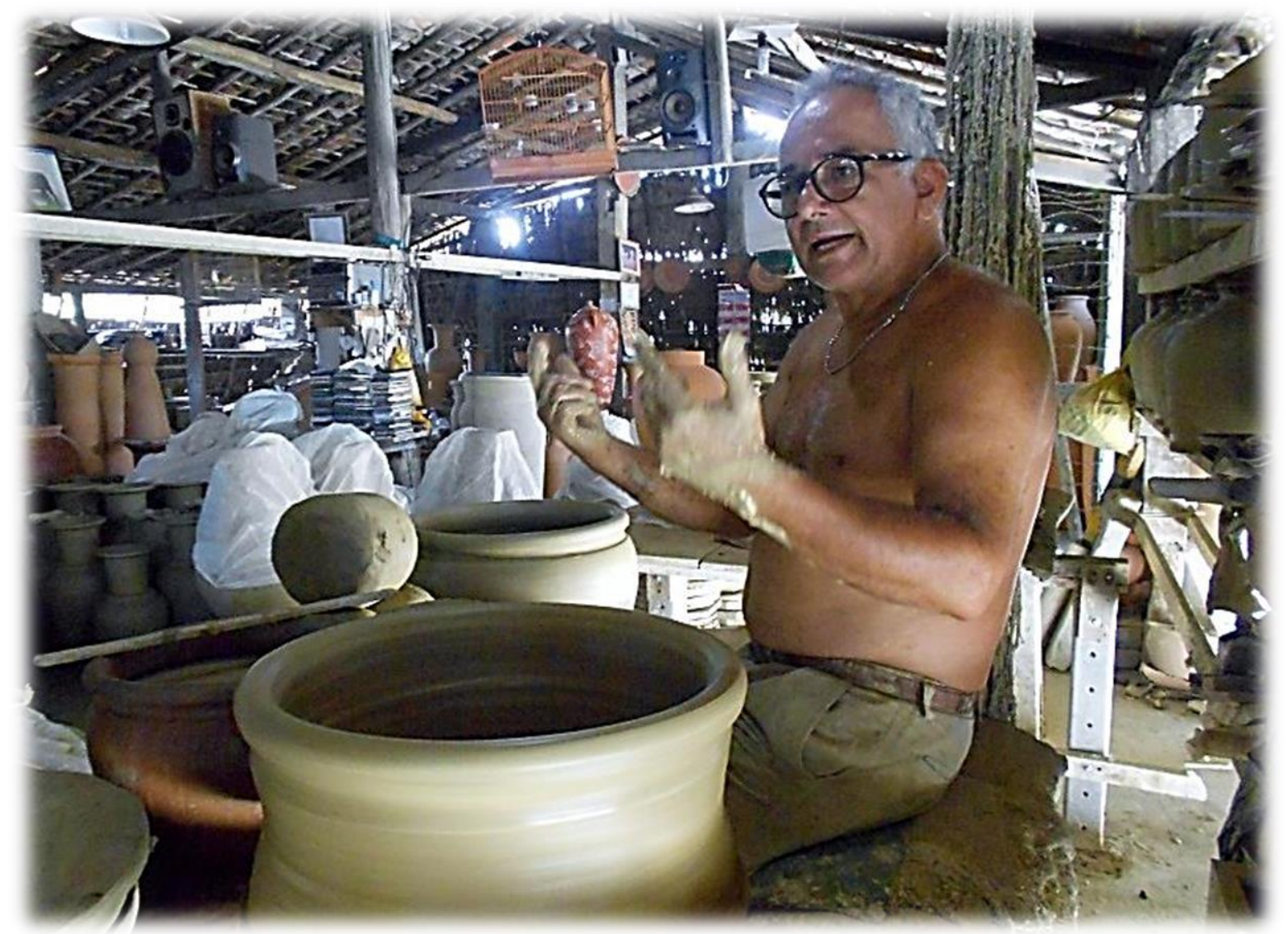

Mestre Miro 


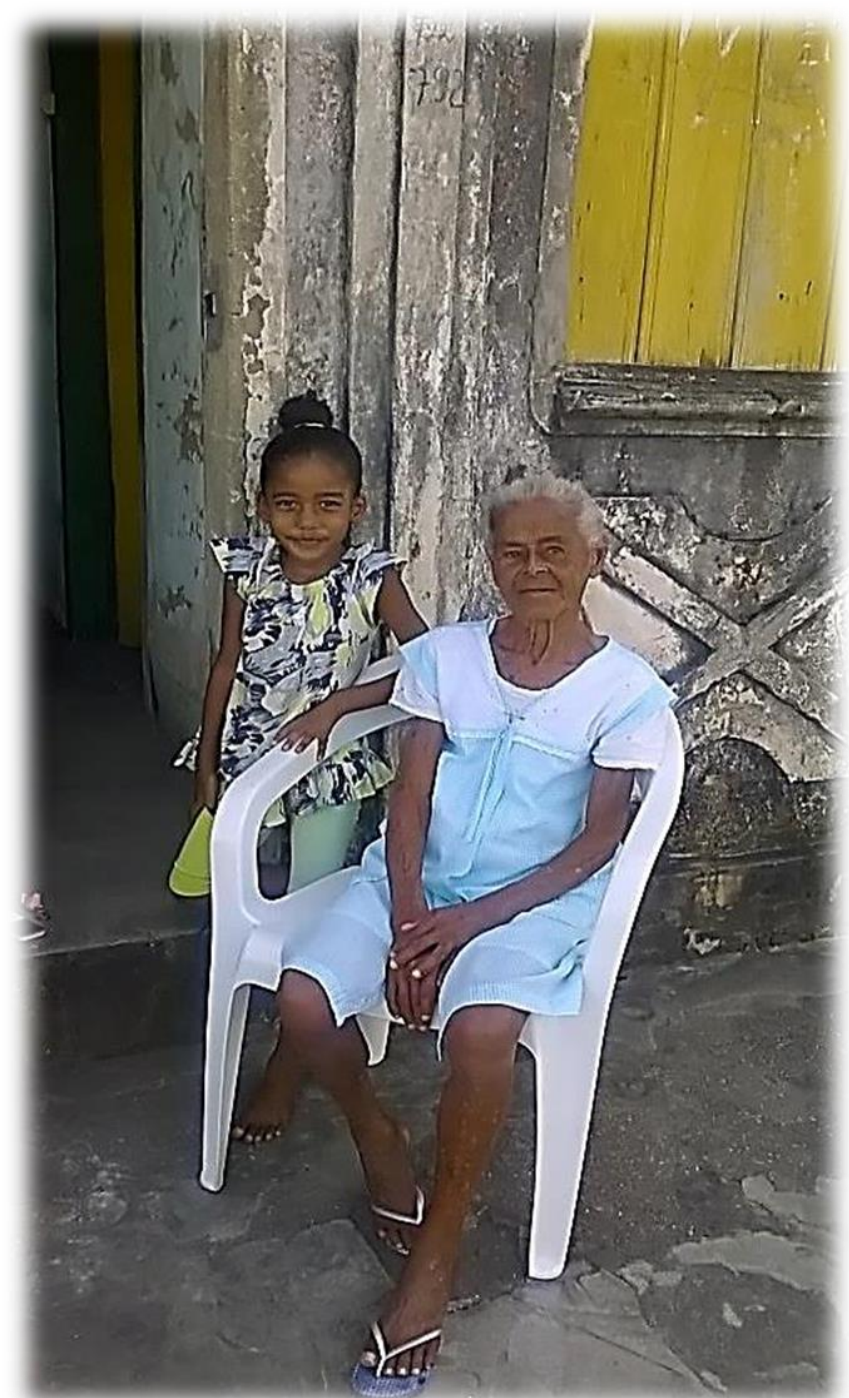

Mestra Rosalina 


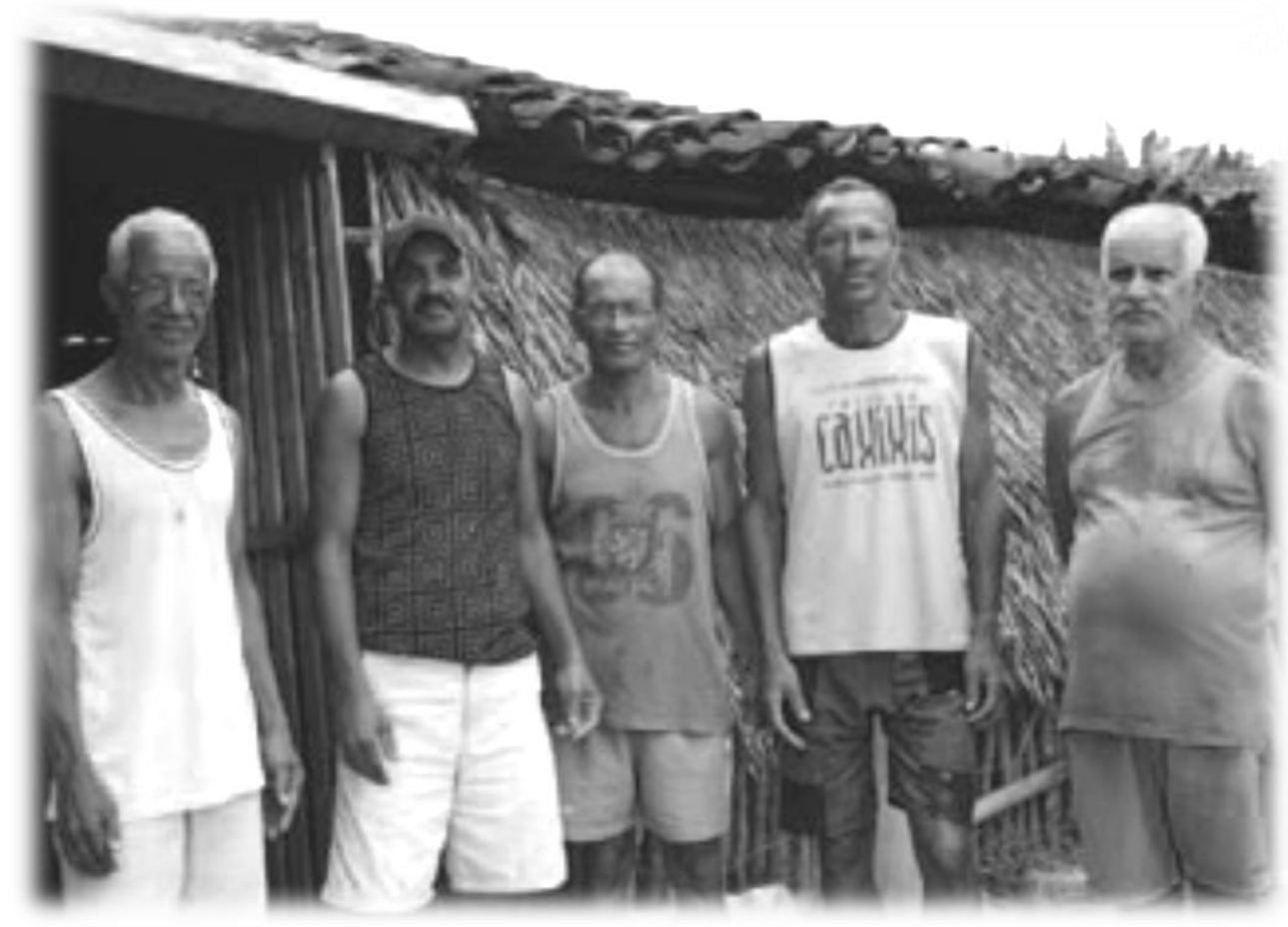

Mestres: Almerentino, Almerentino Filho, Seu Zé, Antônio Luiz e Padre

(Ferraz, 2009, p. 31) 
Olhou em redor e reparou pela primeira vez que tudo ali estava como coberto de barro, não sujo de barro, somente da cor que ele tem, da cor de todas as cores com que saiu da barreira, o que foi sendo deixado por três gerações que todos os dias mancharam as mãos no pó e na água do barro, e também, lá fora, a cor de cinza viva do forno, a derradeira e esmorecente mornidão de quando o deixavam vazio, como uma casa donde saíram os donos e que se deixa ficar, paciente, à espera, e amanhã, se tudo isto não se acabou já para sempre, outra vez a primeira chama da lenha, o primeiro bafo quente que vai rodear como uma carícia a argila seca, e depois, aos poucos e poucos, a tremulina do ar, uma cintilação rápida de brasa, o alvorecer do esplendor, a irrupção deslumbrante do fogo pleno. Saramago, 2000, p. 35. 


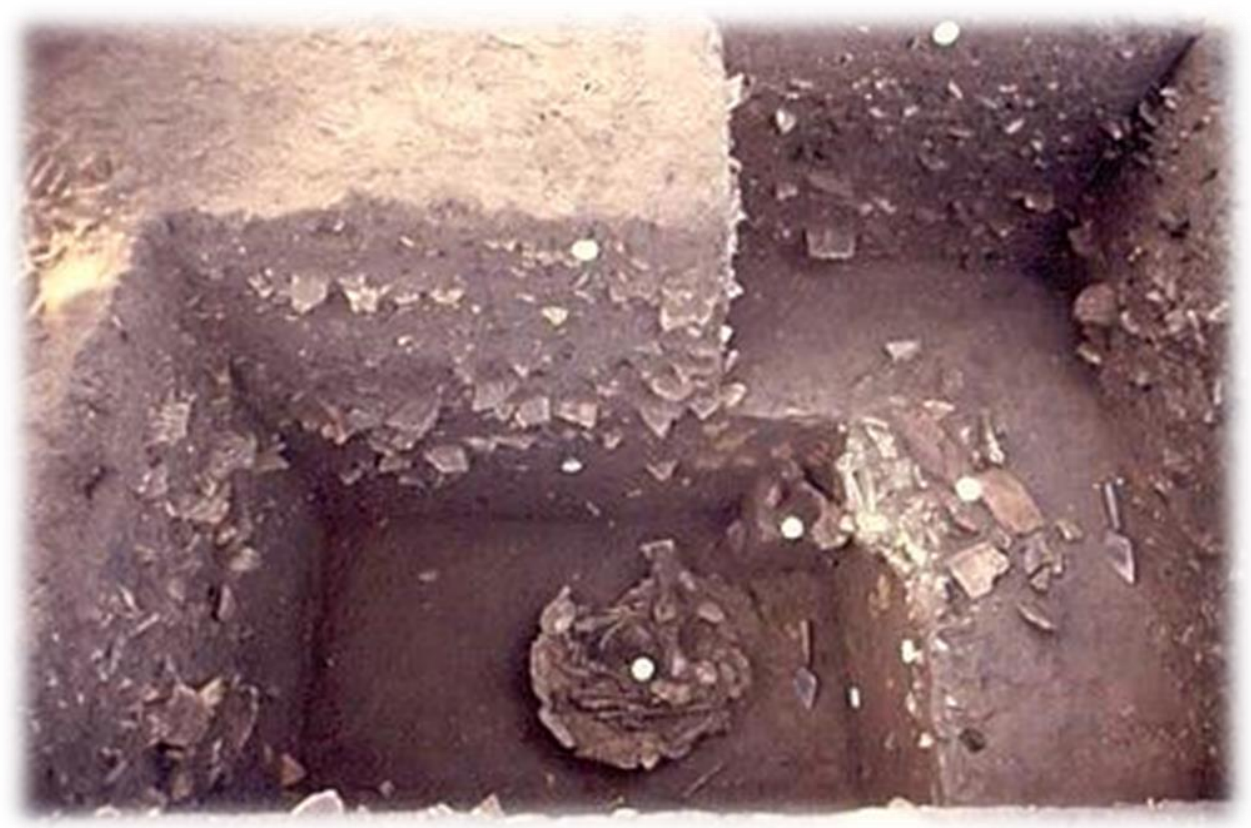

Paredes com fragmentos de cerâmica no sítio arqueológico Hatahara, no Amazonas

(https://s-media-cache-ak0.pinimg.com/736x/54/c4/b4/54c4b47ef09d598a639732844a9165fo.jpg) 


\section{acordes finais}

O barro pra mim significa tudo na vida.

Realização.

O barro me dá saúde, alimentação. Deu uma maneira de educar os meus filhos.

Aqui não tem ninguém milionário, mas todo mundo é rico.

Mestre Almerentino

A palavra tradição foi bastante utilizada nas páginas anteriores. Para alguns, ela pode soar como arcaica, destoando do significado de contemporaneidade. Entretanto, este trabalho buscou demonstrar que a oposição entre tradicional e contemporâneo é artificial e inexiste no fluxo da vida e do tempo. As forças de permanência e mudança amalgamam-se constantemente nos processos socioculturais ao longo da história.

"Tradição" provém do latim traditio que significa "entregar", "transmitir algo a alguém", "confiar alguma coisa valiosa a outra pessoa". O termo tradição evoca essencialmente ao dinamismo e à circularidade que se estabelece entre passadopresente e presente-futuro. A tradição não está congelada no passado, antes 
pressupõe mobilidade, transição, transcendência. A noção de tradição aproximase da compreensão heideggeriana do tempo como escoamento, como fuga generalizada para fora do sujeito, em perpétuo movimento centrífugo (assim como o do torno de oleiro).

A tradição cria e recria. Os ofícios artesanais são os grandes vetores da tradição oral (Hampâté Bâ, 1982) e o artesão é, acima de tudo, um ser criador. Como intérprete da tradição, ele é capaz de adaptar-se e de inovar em diferentes realidades, enquanto reproduz técnicas e padrões adquiridos por herança. Novas formas de criação e antigos segredos de ofício se misturam, numa tensão permanente entre transformação e conservação. $O$ artesão vive o seu legado cultural e o mantém vivo, reinventando-o e atualizando-o eternamente. Esse legado mantém conexão com o passado, mas se reveste de novos símbolos e significados no presente para fortalecer a identidade dos autores e de suas comunidades, e para dar sentido ao futuro.

Os objetos artesanais sofrem metamorfoses que superam questões relativas à forma e à utilidade, abrem-se generosamente a perspectivas diferentes, a novos olhares e usos, a outros valores. $\mathrm{O}$ artesanato tradicional é uma práxis libertadora, 
reintegradora do humano e o acervo de conhecimentos que reúne integra o Patrimônio Cultural Imaterial dos povos.

Patrimônio Cultural Imaterial, ou $\mathrm{PCl}$, de acordo com a Convenção para a Salvaguarda do Patrimônio Cultural Imaterial da UNESCO, de 2003, compreende:

[As] práticas, representações, expressões, conhecimentos e técnicas junto com os instrumentos, objetos, artefatos e lugares culturais que Ihes são associados - que as comunidades, os grupos e, em alguns casos, os indivíduos reconhecem como parte integrante de seu patrimônio cultural. Este patrimônio cultural imaterial, que se transmite de geração em geração, é constantemente recriado pelas comunidades e grupos em função de seu ambiente, de sua interação com a natureza e de sua história, gerando um sentimento de identidade e continuidade e contribuindo assim para promover o respeito à diversidade cultural e à criatividade humana.

Refletir sobre o sentido patrimonial do artesanato, reconhecer e preservar bens culturais de natureza imaterial por meio de planos de salvaguarda estabelecidos de forma conjunta e articulada com os artesãos e artesãs, fortalece uma via que desnaturaliza a barreira entre as classes dominantes e as classes populares, que 
abre espaço para que os conhecimentos científicos e tecnológicos possam interagir com os conhecimentos tradicionais. Canclini admite que: "ainda que o patrimônio sirva para unificar cada nação, as desigualdades em sua formação e apropriação exigem entendê-lo também como espaço de luta material e simbólica entre as classes, as etnias e os grupos" (Canclini, 2003, p. 195).

Tornar Maragogipinho Patrimônio Cultural Imaterial brasileiro emerge como desdobramento deste trabalho, que apenas criou um veio para fortalecer e amparar minha próxima caminhada em direção ao tombamento oficial do povoado pelo Instituto do Patrimônio Histórico e Artístico Nacional.

Salvaguardar um bem de natureza imaterial é, segundo o IPHAN ${ }^{11}$ :

apoiar sua continuidade de modo sustentável, atuar para melhoria das condições sociais e materiais de transmissão e reprodução que possibilitam sua existência. $O$ conhecimento gerado durante os processos de inventário e registro é o que permite identificar de modo bastante preciso as formas mais adequadas de salvaguarda. Essas formas podem variar da ajuda financeira a detentores de saberes

11 INSTITUTO DO PATRIMÔNIO HISTÓRICO E ARTíSTICO NACIONAL, Plano de Salvaguarda, Disponível em: http://portal.iphan.gov.br/pagina/detalhes/684/ 
específicos com vistas à sua transmissão, até, por exemplo, a organização comunitária ou a facilitação de acesso a matérias primas.

Os saberes envolvidos na fabricação da cerâmica de Maragogipinho provêm de técnicas ancestrais com o barro, partilhados comunitariamente com filhos, enteados, sobrinhos, netos e vizinhos, por homens e mulheres que se responsabilizam pela inserção dos mais jovens em seus ofícios. Esses mestres socializam com os aprendizes não somente técnicas, mas, acima de tudo, uma visão de mundo. A valorização e reconhecimento oficial dos modos de fazer, das ferramentas, da morfologia, dos temas e motivos, das olarias, bem como dos próprios artefatos cerâmicos, constituem um meio potente para que os artesãos e artesãs possam seguir produzindo sua cultura.

Diversas ações institucionais podem contribuir para a salvaguarda da Cerâmica de Maragogipinho. Basicamente, podemos estruturá-las em três frentes de execução. A primeira diz respeito ao acesso e à preservação das fontes de matérias-primas: os barreiros, o manguezal, o plantio e a renovação da madeira para queima. A segunda está relacionada ao apoio e às condições para a produção e comercialização das peças pelos próprios ceramistas. A terceira refere-se à valorização profissional dos mestres e mestras, o que inclui direitos previdenciários, garantindo a partilha dos saberes tradicionais, o engajamento dos 
mais jovens na produção, a continuidade do ofício e, sobretudo, o reconhecimento do valor da atividade cerâmica para a identidade do povo de Maragogipinho.

Desde tempos imemoriais, a cerâmica vem sendo uma atividade essencial à humanidade. Para além de sua função primordial na construção de paredes, do piso e do telhado das moradas, na contenção e armazenamento da água ou no cozimento dos alimentos, a cerâmica nutre o homem dos sonhos elementares da terra, da água, do fogo e do ar. A modelagem do barro reaviva e contenta o inexorável desejo terreno da criação original.

Bachelard diz: "todo o verão está dentro de uma flor" (2003, p. 41). Do mesmo modo, Maragogipinho é verdadeiramente um território de gênese, a cerâmica habita essa pequena comunidade, completa-a e dignifica-a.

Ao finalizar este trabalho, uma última imagem espelha-se em meus olhos: a da escavação de um sítio arqueológico apinhado de restos cerâmicos. Vi-a projetada 
em uma palestra ${ }^{12}$, recentemente, e não consigo esquecê-la. A cova era funda, quadrada, e foi fotografada de cima para baixo. Mostrava camadas superpostas de fragmentos de cerâmica que haviam sido enterrados em distintas épocas. Os cacos despontavam para fora da terra.

Esta imagem prontamente me remeteu a mais uma passagem do livro "A caverna", em que o oleiro Cipriano Algor, após ter suas louças de barro recusadas pelo Centro (instituição que comprava sua produção), preteridas em favor das novas louças de plástico, cava um buraco e enterra ali centenas de utensílios cerâmicos. Ao fazê-lo, presume o que acontecerá quando forem descobertos mais tarde:

(...) imagina a piada que seria assistirmos, daqui a uns mil ou dois mil anos aos debates dos arqueólogos e dos antropólogos sobre a origem e as razões da presença de uma tal quantidade de pratos, canecas e panelas de barro, e sua problemática utilidade num sítio como este (Saramago, 2000, p. 109).

12 Palestra de Cristiana Barreto: "Cerâmicas do Brasil", no Museu A Casa, em São Paulo, SP, setembro de 2015. 
Durante mais de vinte anos, seguindo o costume iniciado por uma colega também professora de $\operatorname{artes}^{13}$, enterrava trabalhos de argila que os alunos deixavam para trás em um terreno abandonado nos fundos do colégio em que lecionava. Divertia-me imaginando os pensamentos de quem um dia achasse aqueles cacos de barro tão expressivos: pedaços de bonecos, bichos, potes, esculturas.

Fragmentos de cerâmica foram e continuam sendo abundantemente encontrados em escavações arqueológicas de todas as épocas, material muito fecundo ao estudo das culturas passadas. Objetos que da terra nasceram e para a terra retornaram. Objetos que renascem carcomidos tempos depois para revelarem segredos soterrados.

Este também é o movimento das culturas: nascem, transformam-se, morrem e revivem novamente. Podem mergulhar no esquecimento em determinados momentos da história, mas ressurgem em outros, como na lenda do Fênix, pássaro da mitologia grega, que morria, para depois de algum tempo renascer das próprias cinzas. Heller (2004) considera que a História é a história dos confrontos de valores das esferas heterogêneas. Uma vez que um valor alcança ser conquistado por uma cultura, já não pode perder-se de modo absoluto; em um

${ }^{13}$ Mestra Sachiko Ugayama 
tempo adiante é capaz de mergulhar no esquecimento, na degenerescência, porém nunca se extingue; ressurge em outro momento.

Assim enxergo hoje Maragogipinho: como um território de belezas. Muitas delas jazem subterrâneas, entranhadas no lodo do mangue, no terreno atrás da igreja ou no fundo do rio. Belezas que esperam silenciosas para rebrotarem da terra. Não sem antes pedir licença à Nanã, deusa dos pântanos e das lamas, a mais antiga das orixás. Nanã guarda o mistério da vida, da morte e do renascimento, segue protegendo desde sempre a memória ancestral do povo de Maragogipinho. 


\section{referências bibliográficas}

ABBAGNANO, Nicola. Dicionário de Filosofia. São Paulo: Martins Fontes, 2007.

ALVARES, Sonia C. Educação Estética na EJA: A beleza de ensinar e aprender com jovens e adultos. São Paulo: Cortez, 2012.

ANDRADE, Mário. Obras Completas. São Paulo: Livraria Martins Editora, 1938. . O Artista e o Artesão. In: O baile das quatro artes. São Paulo: Martins

Editora, 1975. Disponível em: http://pt.slideshare.net/gersonastolfi/mariode-andrade-o-artista-e-o-arteso/ Acesso em 20/02/2012.

. O turista aprendiz. Belo Horizonte: Itatiaia, 2002.

ANTONIL, André João. Cultura e opulência do Brasil. Belo Horizonte - Rio de Janeiro: Itatiaia: 1997.

ARAÚJO, Emanoel (org.). Negro de corpo e alma. Mostra do Redescobrimento. São Paulo: Fundação Bienal de São Paulo, 2000.

BACHELARD, Gaston. A terra e os devaneios da vontade. São Paulo: Martins Fontes, 2001. . A terra e os devaneios do repouso. São Paulo: Martins Fontes, 2003. 
BARRETO, Cristiana. As culturas são feitas para dialogar? In: BORGES, Adélia \& BARRETO, Cristiana (org.). Pavilhão das Culturas Brasileiras: Puras misturas.

São Paulo: Terceiro Nome, 2010, pp. 209-230.

BASTIDE, Roger. Arte e Sociedade. São Paulo: Editora Nacional e EDUSP, 1971.

BAUMAN, Zygmunt. Identidade. Rio de Janeiro: Jorge Zahar Ed., 2005.

BISILLIAT, Maureen e SOARES, Renato. Museu do Folclore Edison Carneiro-

Sondagem na alma do povo. Rio de Janeiro: Empresa das Artes, 2005.

BORGES, Adélia. Cabeça, mãos e alma: reflexões sobre design + artesanato na

América Latina. São Paulo: A Casa/ Museu do objeto brasileiro, 2011.

Disponível em: http://www.acasa.org.br/biblioteca texto.php?id=334/ Acesso em 03/03/2013.

BOSI, Alfredo. Reflexões sobre a arte. São Paulo: Ática, 1989.

BOSI, Ecléa. Memória e Sociedade. São Paulo: Companhia das Letras, 1994.

BOURRIAUD, Nicolas. Estética Relacional. São Paulo: Martins Fontes, 2011.

BRANDÃO, Carlos R. A cultura do povo, a prática da classe - documento - São

Paulo, março/1980.

. Cultura, culturas, culturas populares e a Educação. TVE Brasil, Programa

Salto para o futuro: Cultura Popular e Educação, Out. 2007.

CANCLINI, Nestor G. As culturas populares do capitalismo. São Paulo: Brasiliense, 1983. 
. Culturas híbridas. São Paulo: EDUSP, 2003.

CARVALHO, José Jorge. Conhecimentos Tradicionais no Brasil e na América Latina: uma agenda de resistência e criatividade. Ministério da Cultura, 2010.

Disponível em:

http://www2.cultura.gov.br/upload/CONHECIMENTOS\%20TRADICIONAIS\% 20NO\%20BRASIL\%20E\%20NA\%20AM\%C9RICA\%20LATINA 1180551213.do c/ Acesso em 31/03/2014.

CASCUDO, Luís da Câmara. Dicionário do Folclore Brasileiro. Belo Horizonte: Itatiaia, 1993.

CERTEAU, Michel. A invenção do cotidiano - Artes de Fazer, Petrópolis: Vozes, 1994.

CHAUÍ, Marilena. Conformismo e Resistência: aspectos da cultura popular no Brasil. São Paulo: Brasiliense, 1986.

CLAUDEL, Paul. Journal. Paris, Bibliothèque de la Pléiade, 1968, vol. I, p.473.

COIMBRA, S. R., MARTINS, F. \& DUARTE, M.L. O reinado da lua: escultores populares do nordeste. Rio de Janeiro: Salamandra, 1980.

COOMARASWAMY, Ananda. Sobre la doctrina tradicional del arte. Madrid: Jose de Gláneta, 2001.

DAGLISH, Lalada. Noivas da Seca: cerâmica popular do Vale do Jequitinhonha. 2.

Ed. São Paulo: UNESP, Imprensa Oficial do Estado de São Paulo, 2008. 
D’ANGELO, Biagio. A utopia do "centro" n'A Caverna, de José Saramago. Revista Ipotesi. Juiz de Fora, v. 15, n. 1, p. 39-46, jan./jun. 2011.

DE VIVES, Vera. A beleza do cotidiano. In: RIBEIRO, Berta \& outros. $O$ artesão tradicional e seu papel na sociedade contemporânea. Rio de Janeiro: FUNARTE, 1983. P. 130-163.

DOHMANN, Marcus. O objeto e a experiência material. Revista Arte e Ensaios. Rio de Janeiro: UFRJ, n. 20, p. 71-77, julho 2010.

ECO, Umberto. História da Beleza. Rio de Janeiro: Record, 2010.

ELIADE, Mircea. Imagens e símbolos. São Paulo: Martins Fontes, 1991. . O mito do eterno retorno. São Paulo: Mercúryo, 1992. . Mito e realidade. 6a ed. São Paulo: Perspectiva, 2004.

FERRAZ, lara (org.). Maragogipinho e a tradição do barro. Rio de Janeiro: IPHAN, CNFCP, 2009.

FERRAZ, lara (org.) \& Teixeira, Nádia B. M. A decoração da cerâmica tradicional de Maragogipinho. Rio de Janeiro: IPHAN, CNFCP, 2011.

FERREIRA, Maria Nazareth. Globalização e identidade cultural na América Latina. São Paulo: CELACC, 2008.

FERREIRA-SANTOS, Marcos. Pessoa, Imaginário e Arte: perspectivas antropológicas em pesquisa. In: TEIXEIRA, M. C. S. \& PORTO, M. R. (org.) Imagens da Cultura: um outro olhar. São Paulo: Plêiade: 1999, pp. 67-88. 
. Mitohermenéutica de la creación: arte, proceso identitário y

ancestralidad. In: Marián López Fernández-Cao. (Org.). Creación y

Posibilidad, Aplicaciones del arte en la integración social. Madrid: Editorial Fundamentos, 2006, pp. 197-242.

. Fundamentos antropológicos da arte-educação: por um 'pharmakon'

na 'didaskalia' artesã. Revista @mbienteducação. São Paulo, v.3, n.2, pp.

59-97, jul/dez 2010.

FERREIRA-SANTOS, Marcos \& ALMEIDA, Rogério de. Antropolíticas da Educação.

São Paulo: Képos, 2011.

FERREIRA-SANTOS, Marcos \& ALMEIDA, Rogério de. Aproximações ao imaginário: bússola de investigação poética. São Paulo: Képos, 2012.

FOCILLON, Henri. Elogio da mão (livro eletrônico). São Paulo: Instituto Moreira Salles, 2012.

FREIRE, Paulo. Pedagogia do oprimido. Rio de Janeiro: Paz e Terra, 2001.

FROCHTENGARTEN, Fernando. Caminhando sobre fronteiras: o papel da educação na vida de adultos migrantes. São Paulo: Summus, 2009.

FROTA, Lélia Coelho. Pequeno dicionário da arte do povo brasileiro, século XX. Rio de Janeiro: Aeroplano, 2005. . Artesanato: Tradição e modernidade em um país em transformação. Revista Patrimonio Cultural Inmaterial Latinoamericano II: artesanías. 
Cusco, Peru: Crespial, 2010. Disponível em:

http://www.crespial.org/es/Publicaciones/index/PU/?pag act=2\&blo act= 1/ Acesso em 15/10/2013.

GIANNOTTI, Sirlene M. Dar forma é Formar-se: Processos criativos da arte para a infância. Dissertação de Mestrado. São Paulo: Faculdade de Educação da USP, 2008.

GROPIUS, Walter. Manifesto Bauhaus. Weimar, 1930. Disponível em:

http://www.arkitekturbo.arq.br/bauhaus manifesto_por.html /Acesso em $30 / 09 / 2012$.

GUSDORF, Georges. Professores para quê? São Paulo: Martins Fontes, 2003.

HAMPÂTÉ BÂ, Amadou. A tradição viva. História Geral da África. São Paulo:

Ática/Unesco, 1982, v.1.

HAUSER, Arnold. Historia social de la literatura y el arte. Vol. I. Madrid: Ed. Guadarrama, 1969.

HELLER, Agnes. O cotidiano e a história. São Paulo: Paz e Terra, 2008.

HUBERMAN, Leo. História da riqueza do homem. Rio de Janeiro: Zahar, 1974.

HUSSERL, Edmund. A ideia da fenomenologia. Lisboa: Edições 70, 2000.

JANELA DA ALMA (filme). Direção de João Jardim. Codireção de Walter Carvalho.

São Paulo, BR distribuidora/Brasil Telecom/Ravina Filmes, 2001. 73 min.

Color. Son. DVD. 
KINSLANSKY, Israel. Kislansky Cerâmicas: argilas do Brasil. São Paulo: SESI, 2013. LEITÃo, Cláudia Sousa. Por uma Ética da Estética: Uma Reflexão acerca da "Ética Armorial" Nordestina. Fortaleza: Universidade Estadual do Ceará, 1997. (Tese de Doutorado).

LEYS, Simon. Ensaios sobre a China. Lisboa: Cotovia, 2005.

LIMA, Beth e LIMA, Valfrido. Em nome do autor: artistas artesãos do Brasil. São Paulo: Proposta Editorial, 2008.

LIMA, Ricardo Gomes. O povo do Candeal: Sentidos e Percursos da louça de barro. Tese de doutorado. Rio de Janeiro: Instituto de Filosofia e Ciências Sociais da Universidade Federal do Rio de Janeiro, 2006. . Objetos: percursos e escritas culturas. São José dos Campos/ SP: Centro de Estudos da Cultura Popular; Fundação Cultural Cassiano Ricardo, 2010. MARAGOGIPINHO. Direção: Guido Araújo. Salvador: UFBA, 1968. Filme, 22 min. Preto e Branco.

MASCELANI, Ângela. O mundo da Arte Popular brasileira. Museu Casa do Pontal. Rio de Janeiro: Mauad, 2002.

MERLEAU-PONTY, Maurice. A Linguagem indireta e as vozes do silêncio. In: Textos escolhidos. Trad. Marilena Chauí. São Paulo: Abril Cultural, 1980. . Fenomenologia da percepção. São Paulo: Martins Fontes, 1999. . O olho e o espírito. São Paulo: Cosac \& Naify, 2004. 
MESTRE VITORINO: HISTÓRIAS DO BARRO. Direção: Bianca Moreira e Thalita Nascimento. Salvador: Instituto Mauá, 2008. Filme, 23 min. Colorido. Disponível em: https://www.youtube.com/watch?v=mg9Aj5sk8nU/ Acesso em: 26/10/2015.

MODELANDO A TRADIÇÃO: TALHAS DE BARRO DE MARAGOGIPINHO. Direção: Igor Souto. Salvador: Instituto Mauá, 2013. Filme, 26 min. Colorido, DVD. MONTES, Maria Lúcia. Os conceitos de folclore e cultura popular. In: BORGES, Adélia \& BARRETO, Cristiana. Pavilhão das Culturas Brasileiras: Puras misturas. São Paulo: Terceiro Nome, 2010, pp. 259-263. . Utensílios no Brasil - Permanência de saberes e de formas. In:

SIQUEIRA, Zaida. Utensílios no Brasil. São Paulo: Ed. Do Autor, 2014, pp. 1721.

MORAES, Sumaya Mattar. Descobrir as texturas da essência da terra: formação inicial e práxis criadora do professor de arte. Tese de Doutorado. São Paulo: Faculdade de Educação da USP, 2007.

MOREIRA, Nádia Bonfim Teixeira. Resgatando a História para preservar o desenho da cerâmica de Maragogipinho a partir do seu processo de construção. Feira de Santana: UEFS, 2010. (Monografia).

MOSTRA DO REDESCOBRIMENTO: Arte Popular. São Paulo: Fundação Bienal, 2000. 
NAKANO, Katsuko. Terra, Fogo, Homem. São Paulo: Aliança Cultural Brasil-Japão, 1989.

NASCIMENTO, Luísa M. A. L. Saberes e fazeres na construção social da maestria: um estudo dos mestres ceramistas da Bahia. Revista Inter-Legere, Natal, UFRN, no 10, p. 81-100, junho de 2012.

ORTIZ, Renato. Cultura brasileira e identidade nacional. São Paulo: Brasiliense, 2006.

OSTROWER, Fayga. Universos da Arte. Rio de Janeiro: Campus, 1983. . Criatividade e processos de criação. Rio de Janeiro: Vozes, 2004.

PALLASMAA, Juhani. La mano que piensa: sabiduría existencial y corporal en la arquitectura. Barcelona: Editorial Gustavo Gili, 2012.

PAZ, Octávio. O artesanato. Disponível em: http://arteomaguas.wordpress.com/oartista-e-o-artesao-feira-omaguas-artesanato-arte-feira-de-artesanatonorma-nacsa-pinheiros-passeios-merleau-ponty/o-artesanato-otavio-paz/ Acesso em 20/03/2011.

. Ver e usar: arte e artesanato. In: Convergências: ensaios sobre arte e literatura. Rio de Janeiro: Rocco, 1991, pp. 45-57.

PEREIRA, Carlos José da Costa. A cerâmica popular da Bahia. Salvador: Progresso, $1957 a$.

. Artesanato e Arte Popular. Salvador: Progresso, $1957 \mathrm{~b}$. 
PORTO ALEGRE, Maria Sylvia. Arte e ofício de artesão: história e trajetória de um meio de sobrevivência. Águas de São Pedro, 1985. Trabalho apresentado no IX Encontro Anual da ANPOCS, 22-25 out.

. Mãos de mestre: Itinerários da Arte e da Tradição. São Paulo: Maltese, 1994.

PULS, Maurício M. Arquitetura e Filosofia. São Paulo: Annablume, 2006.

RIBEIRO, Darcy. O povo brasileiro: a formação e o sentido do Brasil. São Paulo: Cia. das Letras, 2003.

ROCHA, Eliana \& MACHADO, Maria Luíza P. (org.). Saberes e fazeres: artesanato baiano. Instituto Mauá. Salvador: EGBA, 2010.

ROCHA, Sebastião. Artesão: sujeito e objeto de seu trabalho. Disponível em: http://www.scribd.com/word/full/2974453?access key=keyan47z40hvbij1sqfhq8 Acesso em 18/07/2010.

SARAMAGO, José. A Caverna. São Paulo: Companhia das Letras, 2000.

SENNETTT, Richard. O Artífice. Rio de Janeiro: Record, 2009.

SUBIRATS, Eduardo. Cultura popular e crise civilizatória. In: BORGES, Adélia; BARRETO, Cristiana (org.). Pavilhão das Culturas brasileiras: Puras misturas. São Paulo: Terceiro Nome, 2010, pp. 271-278.

TINHORÃO, José Ramos. Cultura popular, temas e questões. São Paulo: Editora 34, 2001. 
TUROK, Marta. Como acercarse a la artesanía. México: Editorial Plaza y Valdés, 1988.

TIRAPELLI, Percival. Arte brasileira, Arte popular. São Paulo: Cia. Editora Nacional, 2006.

UNESCO. Convenção para a Salvaguarda do Patrimônio Cultural Imaterial. Paris: UNESCO, 2003. Disponível em: http://unesdoc.unesco.org/images/0013/001325/132540por.pdf/ Acesso em 25/07/2015.

VALLADARES, Clarival do Prado. Artesanato brasileiro. Rio de Janeiro: FUNARTE, 1978.

VYGOTSKY, Lev S. Psicologia da Arte. São Paulo: Martins Fontes, 2001.

YANAGI, Sõetsu. The unknown craftsman: A japanese insight into beauty. Tradução de Bernard Leach. Tokyo: Kodansha International Ltd., 1972. 


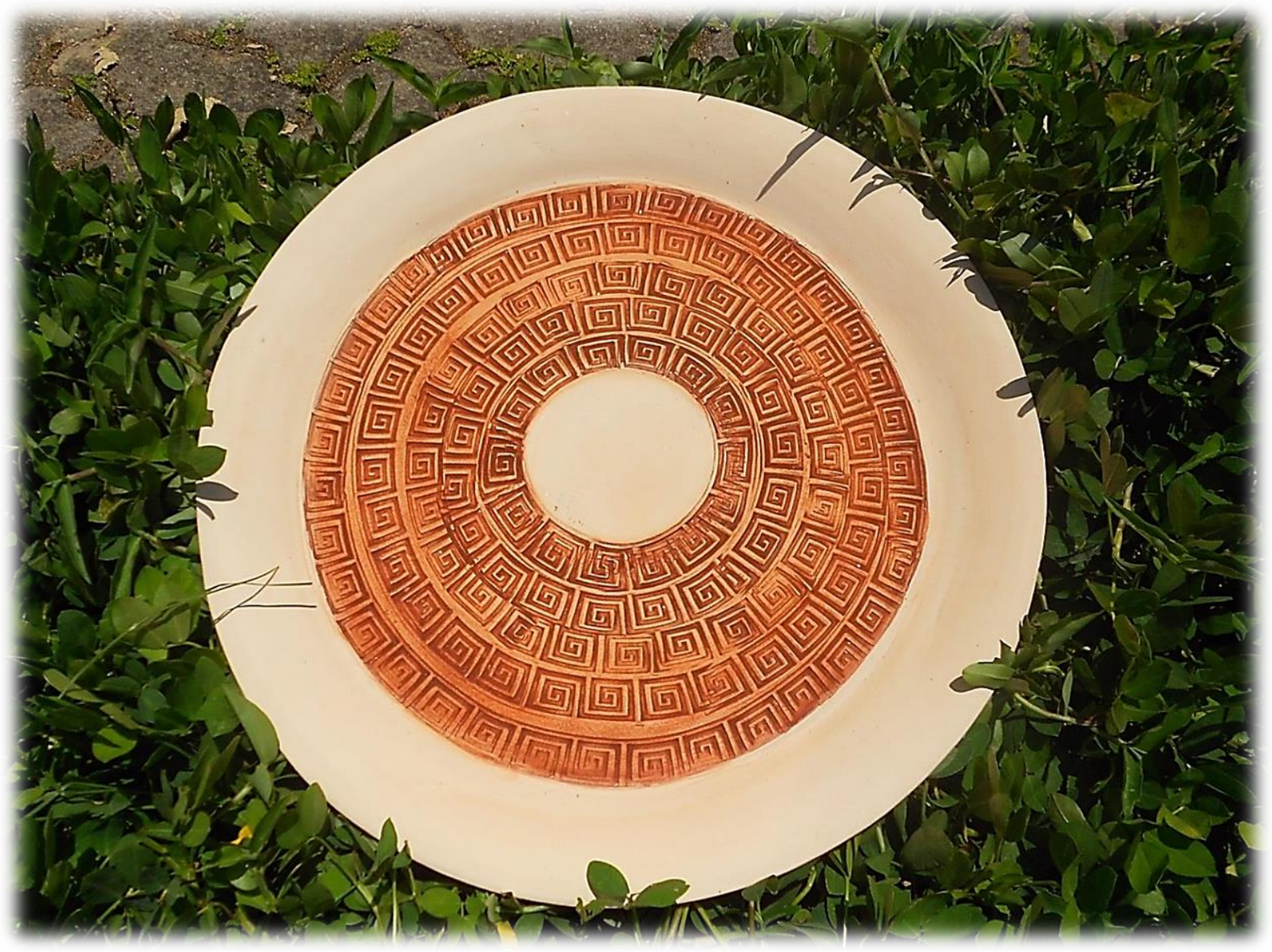

Prato em argila, Sonia Carbonell, 2014 